\title{
241-SY Tank Farm Construction Extent of Condition Review for Tank Integrity
}

\author{
T.J. Barnes, K.D. Boomer, J.R. Gunter, T.J. Venetz \\ Washington River Protection Solutions LLC \\ Richland, WA 99352 \\ U.S. Department of Energy Contract DE-AC27-08RV14800

$\begin{array}{lll}\text { EDT/ECN: } & \text { DRF } & \text { UC: N/A } \\ \text { Cost Center: } & \text { 2KE00 } & \text { Charge Code: } 201522 \\ \text { B\&R Code: } & \text { N/A } & \text { Total Pages: } 183\end{array}$

Key Words: DST, 241-SY Tank Farm, leak, tank construction, extent of condition

Abstract: This report provides the results of an extent of condition construction history review for tanks 241-SY-101, 241-SY-102, and 241-SY-103. The construction history of the 241-SY tank farm has been reviewed to identify issues similar to those experienced during tank 241-AY-102 construction. Those issues and others impacting integrity are discussed based on information found in available construction records, using tank 241-AY-102 as the comparison benchmark. In the 241-SY tank farm, the third DST farm constructed, refractory quality and stress relief were improved, while similar tank and liner fabrication issues remained.

TRADEMARK DISCLAIMER. Reference herein to any specific commercial product, process, or service by trade name, trademark, manufacturer, or otherwise, does not necessarily constitute or imply its endorsement, recommendation, or favoring by the United States Government or any agency thereof or its contractors or subcontractors.

APPROVED

By G.E. Bratton at 2:12 pm, Jul 25, 2013
Date

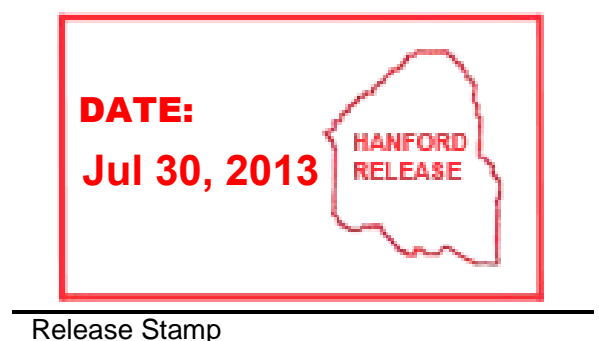

Release Stamp

\section{Approved For Public Release}


RPP-RPT-54819

Revision 0

\section{1-SY Tank Farm Construction Extent of Condition Review for Tank Integrity}

T. J. Barnes

J. R. Gunter

K. D. Boomer

T. J. Venetz

Washington River Protection Solutions, LLC

Date Published

July 2013

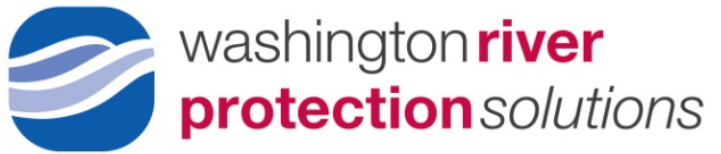

Prepared for the U.S. Department of Energy

Office of River Protection

Contract No. DE-AC27-08RV14800 
RPP-RPT-54819, Rev. 0

\section{EXECUTIVE SUMMARY}

The construction history of the 241-SY tank farm has been reviewed to identify any concerns for the long-term integrity of the tanks. This initial review was prompted by construction issues identified during the formal leak assessment for tank 241-AY-102 (AY-102), RPP-ASMT53793, Tank 241-AY-102 Leak Assessment Report. In tank AY-102, bulges in the secondary liner, deterioration of refractory during post-weld stress relieving (post-weld heat treatment), and primary tank floor plate welding rework during construction left residual stresses in the tank that may have accelerated corrosion and contributed to the primary tank failure. The main purpose of this review was to determine whether the construction methods adopted after completion of the 241-AY Farm either improved the quality and integrity of the third double-shell tank farm built (241-SY tank farm) or produced similar reduced margins.

During construction of the 241-SY tank farm, weld rejection rates for the tanks were similar to the weld rejection rate in tank AY-102. The secondary liner bottom thickness was increased to $3 / 8 \mathrm{in}$. from $1 / 4 \mathrm{in}$. and the primary tank bottom was increased from $3 / 8 \mathrm{in}$. to $1 / 2 \mathrm{in}$. The plate material was also changed from American Society for Testing and Materials (ASTM) A515-65 carbon steel in the 241-AY tank farm to ASTM A516-72 carbon steel in the 241-SY tank farm.

The construction of 241-SY tank farm showed improvement in refractory placement and postweld heat treatment. Minor issues were noted for refractory installation and weather protection, but no significant refractory repairs were required. The post-weld stress relieving process was more disciplined and effective in the 241-SY tank farm. All tanks were successfully post-weld stress relieved with no deficiencies noted.

The most significant deficiency found in the 241-SY tank farm was the presence of bulging in the primary and secondary bottoms. The maximum root to crown slope was found in tank SY103 secondary bottom and had a slope of 1 in. per ft. Structural analysis and strain gauge testing of the bulge was conducted and results indicated the stresses in the tank to be less than the yield strength of the material. Bulging in tank SY-101 was similar in size, shape, and location to the bulge in SY-103. However, it was decided to grout the area underneath two bulges to support the primary tank in those locations.

Various other issues related to difficulties in liner fabrication were noted. All of these issues were evaluated and accepted "as-is” with no stated impact on structural tank integrity.

The 241-SY tank farm had improved construction practices in some areas as compared to tank AY-102, yet many of the construction issues experienced by tank AY-102 re-emerged. Overall, the condition of the tank liners in the 241-SY tank farm are considered to be similar to tank AY102. Factors thought to have caused unsupported areas in the primary tank bottom and the potential for areas of high residual stress in tank AY-102 are also present in all of the 241-SY tank farm tanks. 


\section{TABLE OF CONTENTS}

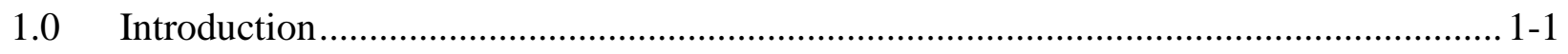

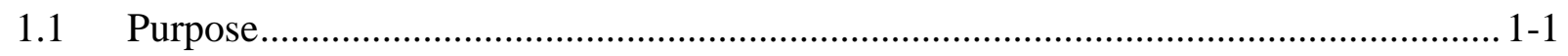

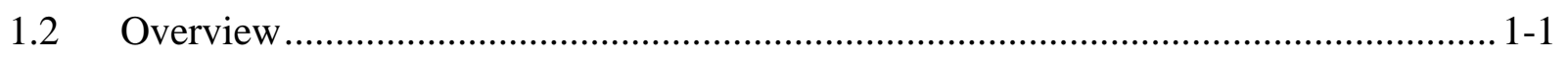

1.3 Double-Shell Tank Description .................................................................... 1-2

$2.0 \quad$ 241-SY Tank Farm Construction Information....................................................... 2-1

3.0 Materials of Construction ................................................................................ 3-1

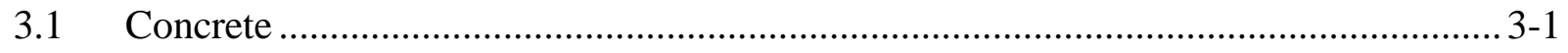

3.2 Reinforcing Bar.......................................................................................

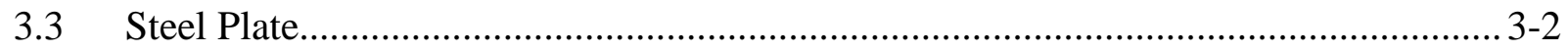

3.3.1 Secondary Plate....................................................................................

3.3.2 Primary Plate .................................................................................... $3-2$

3.3.3 Material Certification..............................................................................

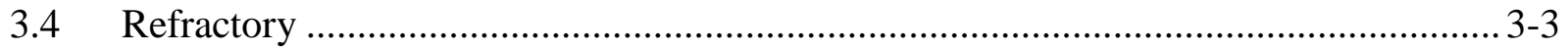

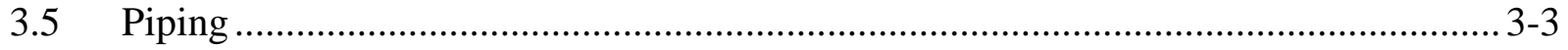

4.0 Construction Sequence..................................................................................... $4-1$

4.1 Concrete Foundation ......................................................................................... $4-2$

4.2 Secondary Liner Bottom ..................................................................................... 4-2

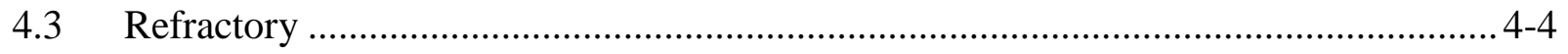

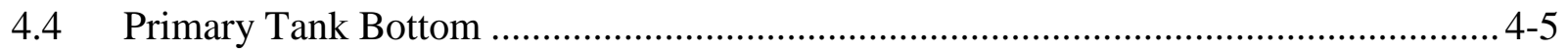

4.5 Primary Tank Wall and Tank Dome ....................................................................

4.6 Secondary Liner Wall and Concrete Shell ............................................................. 4-7

4.7 Primary Tank Stress Relieving ...................................................................... 4-7

4.8 Primary Tank Hydrostatic Test ......................................................................... 4-10

4.9 Complete Secondary Liner Wall and Tank Penetrations ...................................... 4-11

4.10 Concrete Dome Pour ................................................................................. 4-12

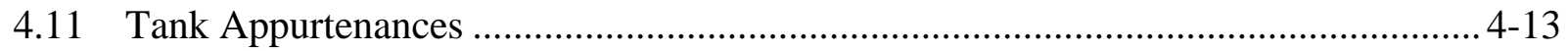

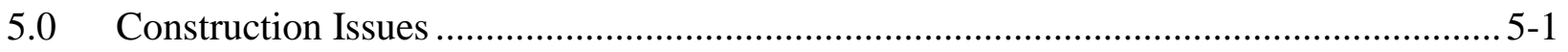

5.1 Weld Rejection and Non-Destructive Examination.............................................. 5-2

5.2 Tank Bottom Flatness .......................................................................... $5-6$

5.2.1 Secondary Liner Bottom Flatness ............................................................ 5-6

5.2.2 Primary Tank Bottom Flatness ................................................................... 5-10

241-SY Tank Farm Bottom Flatness Issues Summary .................................... 5-17

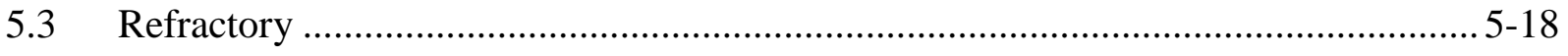




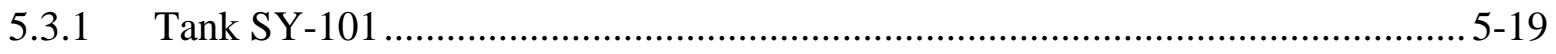

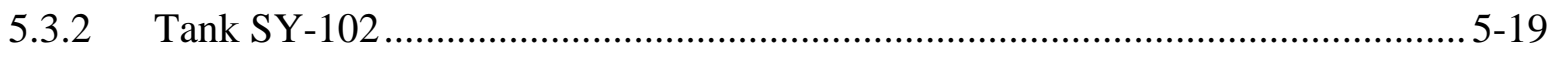

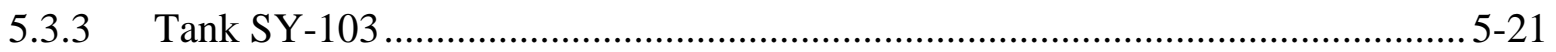

5.3.4 241- SY Tank Farm Refractory Issues Summary ……………………….............. 5-22

5.4 Issues Unique to 241-SY Tank Farm ................................................................. 5-22

5.4.1 Deformation of Tank SY-102 Secondary Liner.................................................. 5-22

5.4.2 Weld Splice Joint ....................................................................................... 5-23

5.4.3 Air Leak During Concrete Dome Pour ………………………............................ 5-24

5.4.4 Primary Tank Bottom Plate Drop ……………............................................ 5-24

5.4.5 Tank Bottom Lowering Swivel Condition......................................................... 5-24

5.4.6 Primary and Secondary Shell Tolerances ……………………………............... 5-25

5.4.7 Tank Dome Drooping …………................................................................ 5-31

5.4.8 Concrete Issues .......................................................................................... 5-33

5.4.9 Tank Elevations .......................................................................................... 5-33

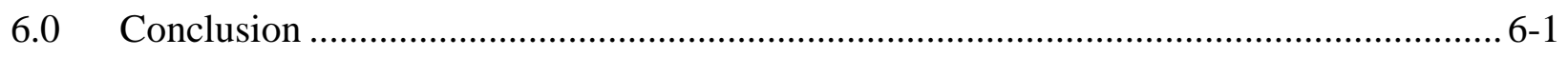

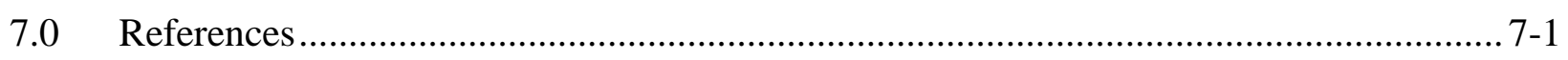

\section{TABLE OF APPENDICES}

Appendix A 241-SY Farm Key Event Table................................................................. A-1

Appendix B 241-SY Weld Maps ................................................................................ B-1

Appendix C Tank Deficiency Documentation .................................................................... C-1

\section{LIST OF FIGURES}

Figure 1-1. Double-Shell Tank Construction................................................................... 1-2

Figure 3-1. Primary Tank Wall Configuration and Thickness ................................................... 3-3

Figure 4-1. 241-SY-Farm Structural Concrete …………........................................................ 4-2

Figure 4-2. Crews Fabricating Secondary Liner Bottom (Photo 64775-12) (Taken 9-2374)

Figure 4-3. Lowering of Secondary Liner Bottom Using Hydraulic Jacks (Photo 66898-3) (Taken 12-9-1974) .

Figure 4-4. Secondary Liner Lower Knuckle Section for Tank 241-SY-101 (Photo 64516-

8) (Taken 8-20-74) ....

Figure 4-5. Tank SY-102 with Refractory Cut Out Over Air Ventilation Supply Pipes and Air Channels Cut into Refractory (Taken 10-21-74).

Figure 4-6. Tank 241-SY-102 with Refractory Filled in Over Air Ventilation Supply

Pipes and Air Channels Cut into Refractory (Photo 66542-6) (Taken 10-22-74)... 
Figure 4-7. Protective Layer Installed Over Refractory for 241-SY-101 and 241-SY-102.

(Photo 66534-1) (Taken 10-21-74) ................................................................................... 4-5

Figure 4-8. Crews Fabricating Primary Tank Bottom (Photo 66771-26) (Taken 11-21-74)...... 4-5

Figure 4-9. Fabricators Welding the Tank Dome Sub-Assemblies (Photo 67722-39)

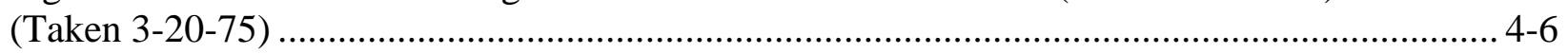

Figure 4-10. Tank Dome Support (Photo 68847-35 and 68847-38) (Taken 4/18/75)............... 4-6

Figure 4-11. Secondary Liner Wall Fabrication and Primary Tank Wall (Photo 68847-37)

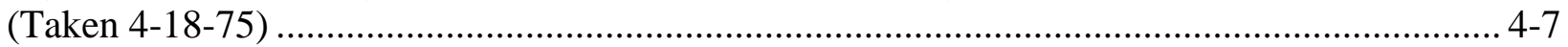

Figure 4-12. Cross-Section of Primary Tank and Refractory ............................................ 4-7

Figure 4-13. Two Courses of Concrete........................................................................... 4-8

Figure 4-14. Insulation Covering the Primary Tank of SY-102 Prior to Stress Relieving

(Photo 69402-39) (Taken 6-19-75) ................................................................................... 4-8

Figure 4-15. Partial Backfill of Tank SY-103 (Photo 69620-44) (Taken 7-22-75).................. 4-10

Figure 4-16. Detail 9 From H-2-37772, Showing the Intersection Between the Secondary Liner and Primary Tank Dome ................................................................................. 4-11

Figure 4-17. Crews Installing Rebar Prior to Concrete Dome Pour (Photo 70273-26)

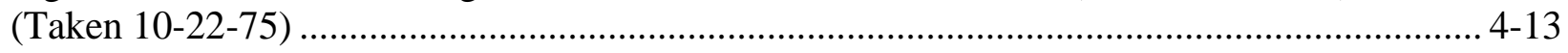

Figure 4-18. Completion of Tank Dome Concrete (Photo 70273) (Taken 10-22-75).............. 4-13

Figure 5-1. Tank SY-101 Primary Weld Map .................................................................. 5-5

Figure 5-2. Secondary Liner Bulges During Pouring of the SY-101 Refractory (Photo 64906-8) (Taken 10-4-74)........................................................................................... 5-7

Figure 5-3. Tank SY-102 Sketch of Bulging Within the Tangent Line to the Knuckle............. 5-8

Figure 5-4. Attachment to NCR B-101-24-2307-9 Showing Location 1 and Location 2 ........... 5-9

Figure 5-5. Cross-Sectional Illustration of Tank SY-103 Waste Tank.................................. 5-14

Figure 5-6. Battelle Strain Gauges on Primary Tank SY-103 (Photo 756534-20) (Taken

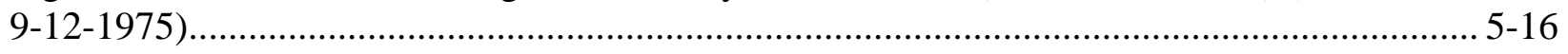

Figure 5-7. Diagram from Report on Field Investigation of the Tank 102-SY Insulating Concrete Around Tank Perimeter After Primary Tank Stress Relieving ............................... 5-21

Figure 5-8. Tank Bottom Jack Location ........................................................................ 5-23

Figure 5-9. Attachment to NCR B-101-35-2307-20 Showing Deviations and Locations......... 5-26

Figure 5-10. Attachment to NCR B-101-29-2307-16 Showing Out-of-Tolerance

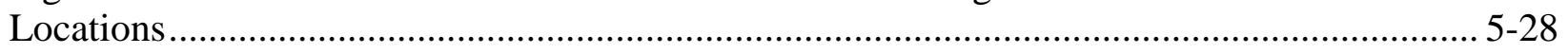

Figure 5-11. Attachment to Deficiency Report \# 31 Showing Out-of-Tolerance Condition .... 5-30

Figure 5-12. Attachment to NCR B-101-37-2307-21 Showing Dome Deviations .................. 5-32 


\section{LIST OF APPENDIX FIGURES}

App Figure B-1. Tank SY-101 Primary Tank Bottom Weld Map ...........................................-2

App Figure B-2. Tank SY-102 Primary Bottom Weld Map.....................................................3

App Figure B-3. Tank SY-103 Primary Bottom Weld Map...................................................4

App Figure B-4. Tank SY-101 Secondary Bottom Weld Map.................................................5

App Figure B-5. Tank SY-102 Secondary Bottom Weld Map...............................................6-6

App Figure B-6. Tank SY-103 Secondary Bottom Weld Map..................................................7

App Figure B-7. SY-101 Primary Shell Weld Map...............................................................8

App Figure B-8. SY-102 Primary Shell Weld Map..............................................................9

App Figure B-9. SY-103 Primary Shell Weld Map.............................................................. B-10

App Figure B-10. SY-101 Secondary Shell Weld Map........................................................-11

App Figure B-11. SY-102 Secondary Shell Weld Map........................................................-12

App Figure B-12. SY-103 Secondary Shell Weld Map........................................................

App Figure C-1. Weld Rejection Correspondence .................................................................2

App Figure C-2. NCR B-101-34-2307-19, 241-SY Tank Farm Salt Cake Storage Facility .......C-6 App Figure C-3. NCR B-101-22-2307-8, 241-SY Tank Farm Salt Cake Storage Facilities.....C-10 App Figure C-4. NCR B-101-20-2307-6, 241-SY Tank Farm Salt Cake Storage Facilities.....C-12 App Figure C-5. NCR B-101-21-2307-7, 241-SY Tank Farm Salt Cake Storage Facilities.....C-15 App Figure C-6. NCR B-101-24-2307-9, 241-SY Tank Farm Salt Cake Storage Facilites......C-18 App Figure C-7. Oct 1, 1975 Letter to J.F. Albaugh ...........................................................20

App Figure C-8. May 4, 1976 Letter to V.D. Schrag ............................................................22

App Figure C-9. Record of Design/Field Change B-101-128, 241-SY Tank Farm Salt

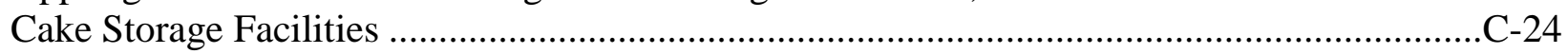

App Figure C-10. SY-101 Grout Out-of-Tolerance Distortion ..............................................-32

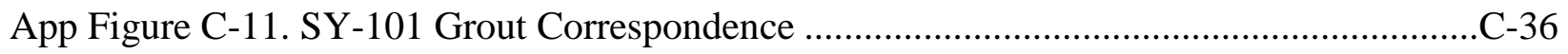

App Figure C-12. Investigation of Tank SY-102 Insulating Refractory …..............................47

App Figure C-13. NCR B-101-32-2307-17, 241-SY Tank Farm Salt Cake Storage

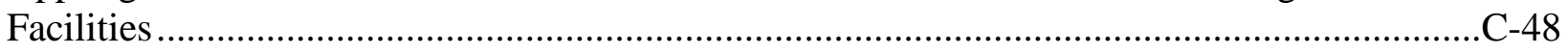

App Figure C-14. NCR B-101-19-2307-5, 241-SY Tank Farm Salt Cake Storage Facilities

App Figure C-15. NCR B-101-25-2307-10, 241-SY Tank Farm Salt Cake Storage Facilities

App Figure C-16. NCR B-101-26-2307-11, 241-SY Tank Farm Storage Facilities ................C-60 
App Figure C-17. NCR B-101-33-2307-18, 241-SY Tank Farm Salt Cake Storage

Facilities

App Figure C-18. NCR B-101-35-2307-20, 241-SY Tank Farm Salt Cake Storage

Facilities

App Figure C-19. Tank SY-101 Secondary Liner Circumference Deficiency Report $. \mathrm{C}-65$

App Figure C-20. NCR B-101-29-2307-14, 241-SY Tank Farm Salt Cake Storage

Facilities C-66

App Figure C-21. Tank SY-102 Secondary Liner Circumference Deficiency Report .C-67

App Figure C-22. NCR B-101-31-2307-16, 241-SY Tank Farm Salt Cake Storage Facilities .C-68

App Figure C-23. Tank SY-103 Primary Local Distortion Deficiency Report. .C-70

App Figure C-24. NCR B-101-38-2307-22, 241-SY Tank Farm Salt Cake Storage

Facilities

App Figure C-25. NCR B-101-37-2307-21, 241-SY Tank Farm Salt Cake Storage Facilities $. \mathrm{C}-75$

App Figure C-26. NCR B-101-39-2307-23241-SY Tank Farm Salt Cake Storage Facilities .C-77

\section{LIST OF TABLES}

Table 1-1. Double-Shell Construction and Age as of 2013 ................................................... 1-2

Table 3-1. Material Comparison Between the 241-AY and 241-SY Tank Farms...................... 3-1

Table 4-1. Post Weld Stress Relieving in 241-SY Tank Farm .............................................. 4-9

Table 5-1. 241-SY Tank Farm Major Non-Conformance/Deficiency Report List .................... 5-1

Table 5-2. 241-SY Tank Farm Primary Tank Bottom Weld Comparison................................. 5-2

Table 5-3. 241-AY Tank Farm Primary Tank Bottom Weld Comparison ................................ 5-3

Table 5-4. 241-SY Tank Farm Non-Destructive Examinations Used During Construction ....... 5-4

Table 5-5. Bulges by Tank......................................................................................... 5-18

Table 6-1. Summary Comparison 241-SY Tank Farm Construction to Tank AY-102 .............. 6-2 
RPP-RPT-54819, Rev. 0

\section{LIST OF TERMS}

\section{Abbreviations and Acronyms}

AEC

ARHCO

ASME

ASNT

ASTM

BNWL

CBI

DST

ECN

Exxon

LDP

LW50

NCR

NDE

PUREX

TOC

WRPS

WST

\section{Units}

$\begin{array}{ll}\mathrm{ft} & \text { Feet } \\ \text { in } & \text { Inch } \\ \mathrm{h} & \text { Hour } \\ \mathrm{lb} & \text { Pound } \\ \text { Mgal } & \text { Million Gallons }\end{array}$

Atomic Energy Commission

Atlantic Richfield Hanford Company

American Society of Mechanical Engineers

American Society for Nondestructive Testing

American Society for Testing and Materials

Battelle Northwest Laboratory

Chicago Bridge and Iron Company

Double-Shell Tank

Engineering Change Notice

Exxon Nuclear Company

Leak Detection Pit

Lite Wate 50 castable refractory

Non-Conformance Report

Non-Destructive Examination

Plutonium Uranium Extraction Process

Tank Operations Contractor

Washington River Protections Solutions LLC

Waste Storage Tank

\section{TRADEMARK DISCLOSURE}

ASME is a registered trademark of American Society of Mechanical Engineers ASNT is a registered trademark of American Society for Nondestructive Testing ASTM is a registered trademark of American Society for Testing and Materials Kaolite is a registered trademark of Babcock \& Wilcox Company 


\subsection{INTRODUCTION}

This document provides an overview of the construction history noting any difficulties encountered for 241-AZ tank farm, the second double-shell tank (DST) farm constructed. In October 2012, it was determined that the primary tank of DST 241-AY-102 (AY-102) was leaking (RPP-ASMT-53793, Rev. 0, Tank 241-AY-102 Leak Assessment Report). Bulges in the secondary liner, deterioration of refractory during post-weld stress relieving, and primary tank floor plate welding rework during construction compromised the intended robustness and corrosion resistance of the tank AY-102 design and probably contributed to the primary tank's failure.

Following identification of the tank AY-102 probable leak cause, an Extent of Condition (EOC) evaluation was prepared using U.S. Department of Energy's Energy Facilities Contractors Group (EFCOG) Guidance for Extent of Conditions Evaluations. The EFCOG process was used to identify other DSTs with construction, waste storage, or thermal histories similar to that of tank AY-102 (WRPS-1204931, Double-Shell Tank 241-AY-102 Primary Tank Leak Extent of Condition Evaluation and Recommended Annulus Visual Inspection Intervals). The EOC evaluation identified six tanks with similar construction and operating histories for additional evaluation which include: 241-AY-101, 241-AZ-101, 241-AZ-102, 241-SY-101, 241-SY-102, and 241-SY-103. One of the identified evaluations was to identify any similarities in construction that could be a precursor for accelerated corrosion and premature failure.

\subsection{PURPOSE}

The construction history of the 241-SY tank farm has been reviewed to identify issues similar to those experienced during tank AY-102 construction. In this document, those issues and others impacting integrity are discussed based on information found in available construction records, using tank AY-102 as the comparison benchmark.

\subsection{OVERVIEW}

Six double-shell tank (DST) farms were constructed over a period of roughly 18 years (from 1968 to 1986), with a presumed design life of 20 to 50 years. The 241-SY tank farm was the third farm to be constructed and is the focus of this report. Table 1-1, "Double-Shell Construction and Age as of 2013," provides the construction dates, year of initial service, and the expected service life for the DSTs. 
RPP-RPT-54819, Rev. 0

Table 1-1. Double-Shell Construction and Age as of 2013

\begin{tabular}{|c|c|c|c|c|c|c|}
\hline $\begin{array}{c}\text { Tank } \\
\text { Farm }\end{array}$ & $\begin{array}{c}\text { Number of } \\
\text { Tanks }\end{array}$ & $\begin{array}{c}\text { Construction } \\
\text { Period }\end{array}$ & $\begin{array}{c}\text { Construction } \\
\text { Project }\end{array}$ & $\begin{array}{c}\text { Initial } \\
\text { Operation }\end{array}$ & $\begin{array}{c}\text { Service } \\
\text { Life }\end{array}$ & $\begin{array}{c}\text { Current } \\
\text { Age }\end{array}$ \\
\hline 241-AY & 2 & $1968-1970$ & IAP-614 & 1971 & 40 & 42 \\
\hline $241-A Z$ & 2 & $1970-1974$ & HAP-647 & 1976 & 20 & 37 \\
\hline $241-S Y$ & 3 & $1974-1977$ & B-101 & 1977 & 50 & 36 \\
\hline $241-A W$ & 6 & $1976-1979$ & B-120 & 1980 & 50 & 33 \\
\hline $241-A N$ & 7 & $1977-1980$ & B-130, B-170 & 1981 & 50 & 32 \\
\hline $241-A P$ & 8 & $1982-1986$ & B-340 & 1986 & 50 & 27 \\
\hline Total & 28 & & & & & \\
\hline
\end{tabular}

\subsection{DOUBLE-SHELL TANK DESCRIPTION}

Each DST consists of a primary carbon steel tank inside of a secondary carbon steel liner, which is surrounded by a reinforced-concrete shell. The primary steel tank rests atop an eight inch insulating concrete slab, separating it from the secondary steel liner, and providing for air circulation/leak detection channels under the primary tank bottom plate. An annular space of 2.5 feet exists between the secondary liners and primary tanks, allowing for visual examination of the tank wall and secondary liner annular surfaces. The annular space also allows for ultrasonic volumetric inspections of the primary tank walls and secondary liners.

Figure 1-1. Double-Shell Tank Construction

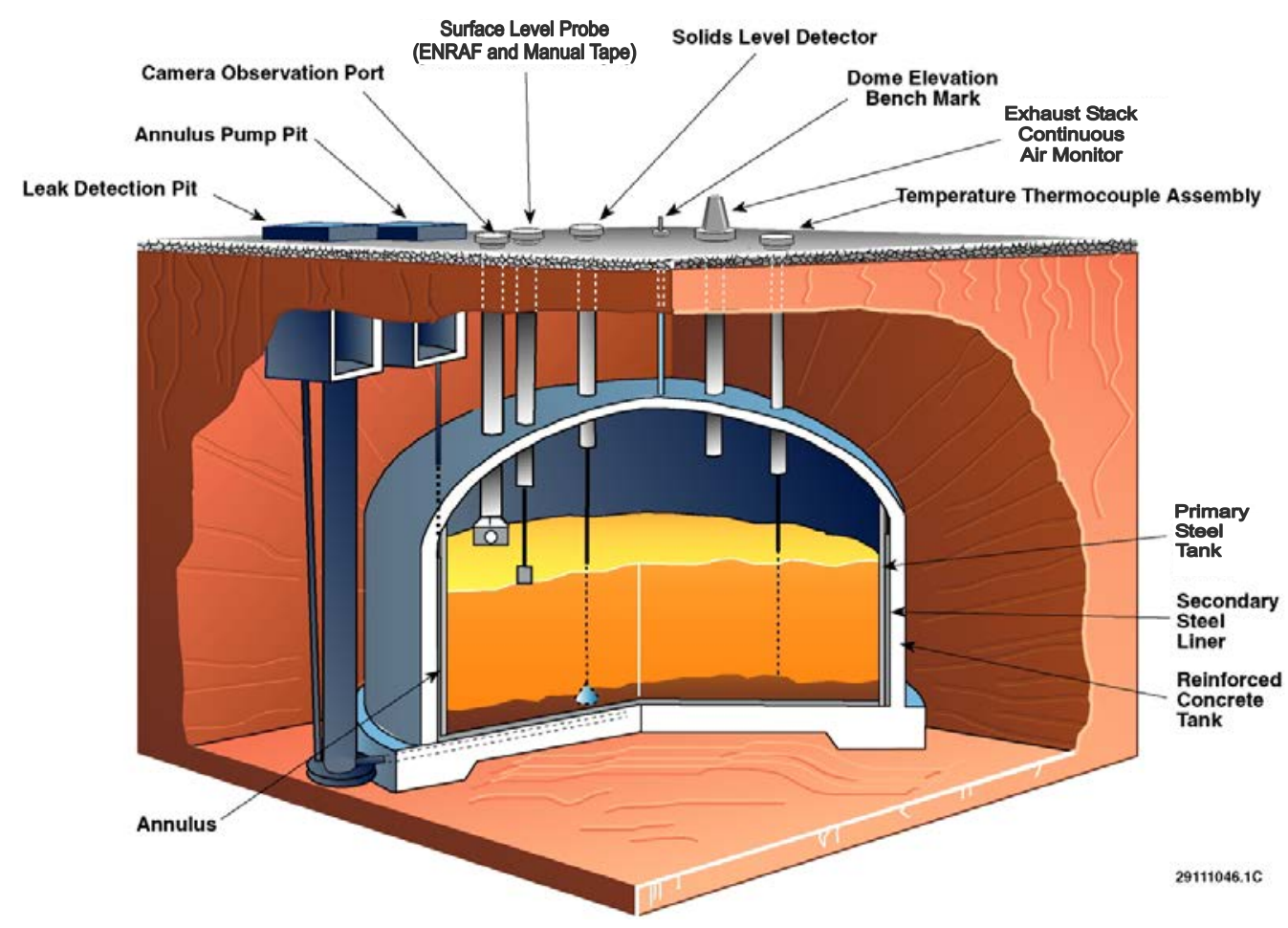


Each tank in the 241-SY tank farm has 58 risers penetrating the dome, providing access for video cameras, ultrasonic inspection devices, waste sampling devices, mixer pumps, and other equipment requiring access to either the primary tank interior or annular space (H-14-010531, Sheets 1, 2, and 3, Dome Penetration Schedules WST/WSTA). Tanks SY-101 and SY-103 each have two pits while tank SY-102 has four pits (H-14-010531, Sheets 1,2, and 3) extending from grade to varying depths, which house valves and pumps. This equipment allows transfer of liquid waste and sludge from SSTs to DSTs, from DSTs to other DSTs, or from DSTs to other facilities (e.g., Waste Treatment and Immobilization Plant). 
RPP-RPT-54819, Rev. 0

\section{$2.0 \quad 241-S Y$ TANK FARM CONSTRUCTION INFORMATION}

The 241-SY tank farm was constructed between 1974 and 1977. It was designated as Project B-101, Saltcake Storage. The Atlantic Richfield Hanford Company (ARHCO) built the tank farm for the Atomic Energy Commission (AEC). The 241-SY tank farm contained three tanks and ancillary equipment. The Chicago Bridge and Iron (CBI) Company was contracted to build the farm. The Pittsburgh Des Moines Steel Company, built the first two double-shell tank (DST) farms. Construction management was provided by Vitro Engineering.

The 241-SY tank farm was built according to ARH-2930, Functional Design Criteria Salt Cake Storage Facilities 241-SY Tank Farm, and the following construction specifications:

- B-101-C1, Specifications for Primary and Secondary Steel Tanks

- B-101-C2, Specifications for Excavation and Tank Foundations

- B-101-C3, Construction Specifications for Completion of 241-SY Tank Farm Project B-101

To obtain information about the construction history, the Record Holding Area (RHA) and Integrated Data Management System (IDMS) were queried for boxes containing files from the Project B-101 Salt Cake Storage.

This information includes:

1. Radiographic Test Diagrams

2. Materials Certifications

3. Non-conformance reports

4. Quality Assurance construction logbooks

5. Project reports, correspondence, and meeting minutes

Daily logbook entries, which describe key construction events and issues, are summarized in Appendix A. The following sections provide an aggregation of the information collected, highlighting important events and information relevant to leak integrity. The resulting quality of construction and any issues or difficulties noted are discussed in this document. 


\subsection{MATERIALS OF CONSTRUCTION}

The materials of construction evolved from the construction of 241-AY tank farm to the construction of the 241-SY tank farm. The primary change in material selection was to use American Society for Testing and Materials (ASTM ${ }^{1}$ ) A516-72, Pressure Vessel Plates, Carbon Steel, for Moderate and Lower Temperature Service, Grade 65 for construction of the primary and secondary liner instead of ASTM A515, Pressure Vessel Plates, Carbon Steel, for Intermediate and Higher Temperature Service, Grade 60, used in the 241-AY tank farm. Also, the thickness of the secondary liner bottom plates was increased starting with the 241-AZ tank farm, from $1 / 4$ in. to $3 / 8$ in. for the secondary bottom sections. The primary bottom was increased from $3 / 8$ in. to $1 / 2$ in. sections. The refractory material was changed from Kaolite ${ }^{2}$ 2200LI castable refractory to Lite Wate 50 castable refractory (LW50). In addition, the refractory pour pattern was modified. Table 3-1 provides a comparison of the construction materials used in the 241-AY and 241-SY tank farms.

Table 3-1. Material Comparison Between the 241-AY and 241-SY Tank Farms.

\begin{tabular}{|l|c|c|}
\hline \multicolumn{1}{|c|}{ Material } & \multicolumn{2}{|c|}{ Tank Farm } \\
\hline & $\begin{array}{c}\text { 241-AY } \\
\text { Conc psi }\end{array}$ & 241-SY \\
\hline Concrete & $\begin{array}{c}\text { Type V for the walls Type III for the } \\
\text { upper haunch and dome }\end{array}$ & $\begin{array}{c}\text { 4500 psi } \\
\text { Type II for the walls } \\
\text { Type III for the upper } \\
\text { haunch and dome }\end{array}$ \\
\hline $\begin{array}{l}\text { Reinforcing } \\
\text { Bar }\end{array}$ & A432 & A615-60 \\
\hline Steel Plate & ASTM A515 65 & ASTM A516 72 \\
\hline Refractory & Kaolite 2200LI & Lite Wate 50 \\
\hline
\end{tabular}

\subsection{CONCRETE}

The structural concrete used in the 241-SY tank farm construction required a 4,500 psi, 28-day compressive strength. Concrete samples were taken and tested at 7 days and 28 days to confirm the compressive strength. The cement for structural concrete conformed to Federal Specification SS-C-192 Type II, except that for the haunch and dome sections of the storage tanks which conformed to Type III (B-101-C3). In the 241-AY tank farm, HWS-7791, Specification for Side Walls and Dome Nuclear Waste Storage Tank Project IAP-614 Purex Tank Expansion, specifies Type V concrete for the tank walls and Type III cement for haunch and dome portions of the tank. From ASTM C150, Standard Specification for Portland Cement, Type II cement is for general use with moderate sulfate resistance and moderate heat of hydration. Type III cement is high early strength cement, and Type V cement is high sulfate resistant cement.

\footnotetext{
${ }^{1}$ ASTM is a registered trademark of American Society for Testing and Materials

${ }^{2}$ Kaolite is a registered trademark of Babcock \& Wilcox Company
} 


\subsection{REINFORCING BAR}

The tank foundation was reinforced with ASTM A615, Grade 60, specifications with a minimum yield strength of 60,000 psi. \#5, \#6, and \#7 rebar was utilized to reinforce the tank foundation (see H-2-37704, Structural Concrete Tank Foundation Plan and Details, for details) while \#4, \#6, \#8, and \#9 rebar was utilized to reinforce the concrete walls and dome sections (see $\mathrm{H}-2-$ 37706, Concrete Tank Section and Haunch Reinforcement, for details).

\subsection{STEEL PLATE}

All primary tank and secondary liner plates used in the 241-SY tank farm were shipped from the United States Steel Corporation and were manufactured to ASTM A516-72, Grade 65, standard. The selection of ASTM A516 was a change from ASTM A515 used in the 241-AY tank farm. ASTM A516 is a fine grain size metal produced for moderate and lower temperature service, while ASTM A515 is a coarse grain size metal produced for moderate and higher temperature service. The smaller grain size in ASTM A516 increases the notch toughness and resistance to stress corrosion cracking over ASTM A515. The 241-SY tank farm tanks were erected using the American Society of Mechanical Engineers (ASME ${ }^{3}$ ), Boiler and Pressure Vessel Code, 1971 through 1973 Editions and Addenda of the code.

\subsubsection{Secondary Plate}

The secondary liner plates consisted of 3/8 in. and 1/2 in. sections (see H-2-37772, Tank Cross Section 241-SY tank farm, for details). The 1/2 in. plate was used in the lower knuckle of the liner. The $3 / 8$ in. plate was used for the liner floor, walls and upper haunch, an increase over the $1 / 4$ in. plate used in the 241-AY tank farm.

\subsubsection{Primary Plate}

The primary tank bottom utilizes primarily $1 / 2$ in. carbon steel plates, except that a $4 \mathrm{ft}$. diameter by 1 in. thick carbon steel plate is located at the center of the primary tank bottom, and a 7/8 in. carbon steel plate is used for the primary bottom knuckle. The primary tank wall thickness varies from 7/8 in. thick carbon steel at the bottom knuckle to 3/8 in. thick at the top transition plate. The first course is $3 / 4$ in. thick, and the next two courses are $1 / 2 \mathrm{in}$. thick. The top transition plate is welded to a 3/8 in. thick top knuckle (see H-2-37772 for details). The dome of the tank was constructed of $3 / 8$ in. plate welded to the top knuckle and after post-weld stress relieving closed with a $6 \mathrm{ft}$. diameter 1/2 in. thick top dollar plate. Figure 3-1 shows the configuration of the primary tank wall and the thickness of each course.

\footnotetext{
${ }^{3}$ ASME is a registered trademark of American Society of Mechanical Engineers
} 


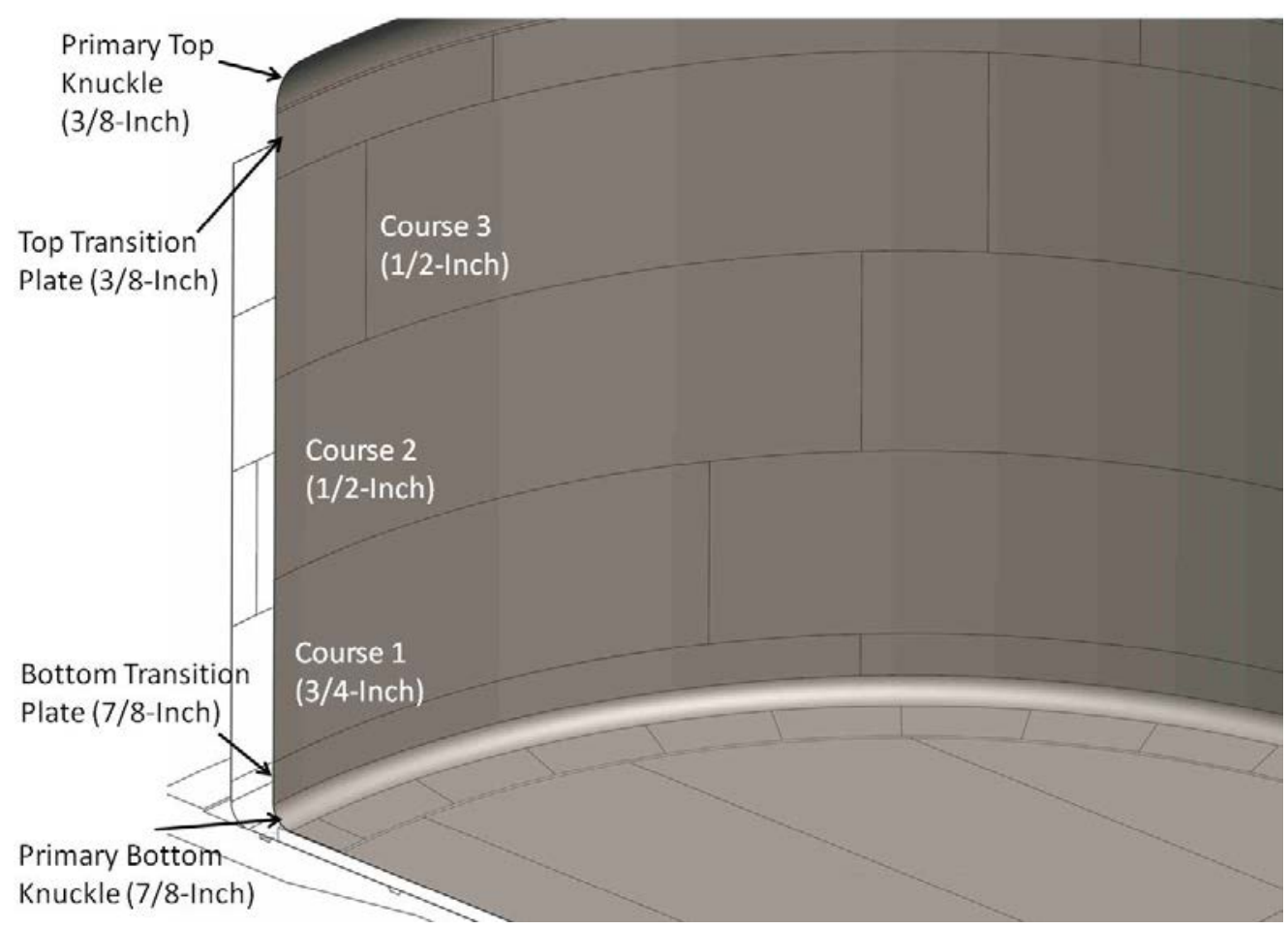

Figure 3-1. Primary Tank Wall Configuration and Thickness

\subsubsection{Material Certification}

Material certifications and chemical and physical test reports were required for each steel plate containing the heat and slab number. Material certifications contained yield strength and tensile strength information along with percent elongation for each specific heat and slab number. The chemical and physical test reports identify the percent of each element (i.e., carbon, manganese, phosphorus, etc.) contained within a sample of the material as well as properties such as, yield point, tensile strength, percent elongation, and information gathered from bend test results.

\subsection{REFRACTORY}

The refractory was required to limit the structural concrete base slab to a maximum temperature of $500{ }^{\circ} \mathrm{F}$ during the post-weld stress relief. The material had to have a minimum compressive strength of 130 psi after heating, either wet or dry. In addition, the material had to be compatible with the chemicals found in the tank waste. The 241-AY tank farm used Kaolite 2200-LI castable refractory, while LW50 was used in the 241-SY tank farm. The effects of freezing LW50 as well as saturating it with water were lab tested. The results can be found in RPP19097, Evaluation of Insulating Concrete in Hanford Double-Shell Tanks, Attachment 9.

\subsection{PIPING}

All pipe used for permanent risers was manufactured to ASTM A53, Grade B, Type S or ASTM A106, Grade A or B specifications. Flanges conform to ASTM A181, Grade I or II specifications. Coal tar enamel wrapped in kraft paper or coal tar tape was used on carbon steel pipe exposed to earth. 


\subsection{CONSTRUCTION SEQUENCE}

Construction of the three 241-SY tanks was awarded to CBI. Excavation began in 1974 and the project was completed in 1977. Vitro Engineering acted as construction management for the project. The site preparation included excavation work and shoring. The shoring was necessary because of the proximity of the 241-S tank farm.

The tanks were constructed simultaneously with SY-102 being built first, followed by SY-101, and with SY-103 following last. A listing of the construction sequence follows:

1. Install concrete foundation on which the secondary liner bottom rests. The foundation has a tertiary leak detection system, which includes a waffle grid in the structural concrete, collection pipes, and the leak detection pit.

2. Install cribbing and jack stands for secondary liner bottom fabrication.

3. Fabricate secondary liner bottom on top of cribbing and jack stands.

4. Inspect secondary liner bottom.

5. Remove jack stands and then cribbing.

6. Lower the secondary liner bottom onto the concrete foundation.

7. Install thermocouple conduits, to be embedded in the tank bottom refractory as well as the retainer ring used as a form for the perimeter of the refractory.

8. Pour the refractory in twelve pour sections.

9. Install the air supply piping with refractory poured around the pipes separately.

10. Install heating matrix, protective covering for refractory and, cribbing and jack stands for primary tank bottom fabrication.

11. Fabricate primary tank bottom on top of cribbing and jack stands.

12. Inspect primary tank bottom.

13. Weld the first plate course (skirts) to the primary tank and secondary liner.

14. Weld second plate course (initial plate course) to primary tank.

15. Remove jack stands and then the cribbing.

16. Lower the primary tank bottom onto the refractory.

17. Install center support post to support dome sections.

18. Continue construction of the primary and secondary liner walls.

19. Fabricate and visually inspect the primary tank dome and dome penetrations.

20. Remove center support post.

21. Place the concrete shell.

22. Start backfilling the tank farm area.

23. Insulate and provide post-weld stress relief for stress relief of the primary tank.

24. Conduct hydrostatic test of the primary tank.

25. Install upper haunch plates for the secondary liner.

26. Tack-weld the flashing to cover the gap between the secondary liner and primary tank to prevent concrete from entering the annulus.

27. Install reinforcing steel and pour concrete over the upper haunch area and tank dome.

28. Install appurtenances (thermocouple trees, pumps, etc.).

29. Backfill to top of the domes.

30. Install the waste transfer system of piping, pump pits, and valve pits.

31. Complete backfill. 


\subsection{CONCRETE FOUNDATION}

The structurally reinforced concrete foundation is $89 \mathrm{ft}-6$ in. in diameter and is designed to distribute all weight loads uniformly. The circular center portion of the foundation is $6 \mathrm{ft}$. in diameter and $2 \mathrm{ft}$. thick. From the circular center portion, the foundation decreases to about $1 \mathrm{ft}$. thick, and then increases to a thickness of $2 \mathrm{ft}$. at the outer edge. The structural foundation contains slots to direct any leakage to drain lines which empty to a leak detection pit (LDP). The foundation is composed of

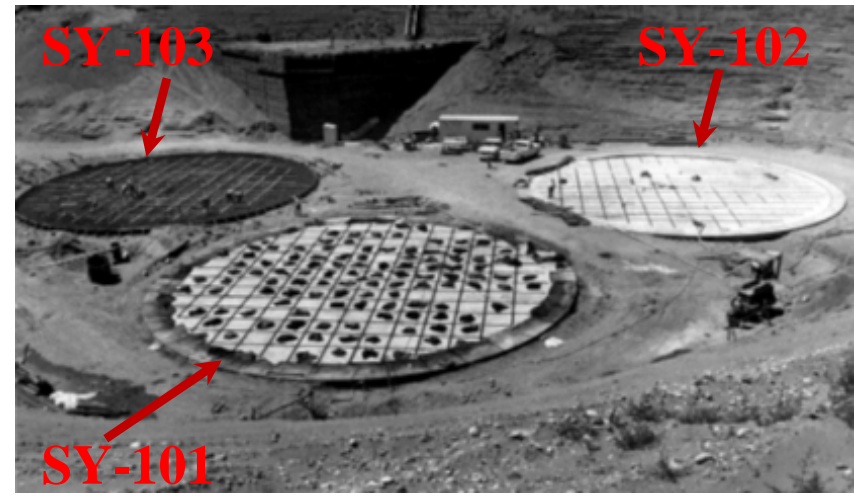

Figure 4-1. 241-SY-Farm Structural Concrete reinforced concrete requiring a 4500 psi, 28 day compressive strength (see B-101-C3). Figure 4-1 shows the construction progress of concrete foundations for the 241-SY tank farm. The concrete has been poured for tanks SY-101 (in the foreground) and SY-102. The reinforcing bar has been placed for tank SY-103. In the background are the shoring piles that were driven to prevent the soil from slumping and exposing the tanks in the adjacent 241-S tank farm.

\subsection{SECONDARY LINER BOTTOM}

The secondary liner bottom has an $80 \mathrm{ft}$. diameter, and the primary tank is $75 \mathrm{ft}$. in diameter, which results in a $21 / 2 \mathrm{ft}$. wide annular space between the primary tank and secondary liner. The secondary liner bottom was constructed onsite on jack stands and cribbing over the foundation. A protective cover of plywood and sand was placed over the foundation to minimize damage to the concrete. The secondary liner bottom knuckles were fabricated in sections at an offsite location by CBI and then shipped to the worksite to join them to the bottom plates. The secondary liner bottom plates are $3 / 8$ in. thick carbon steel and the bottom

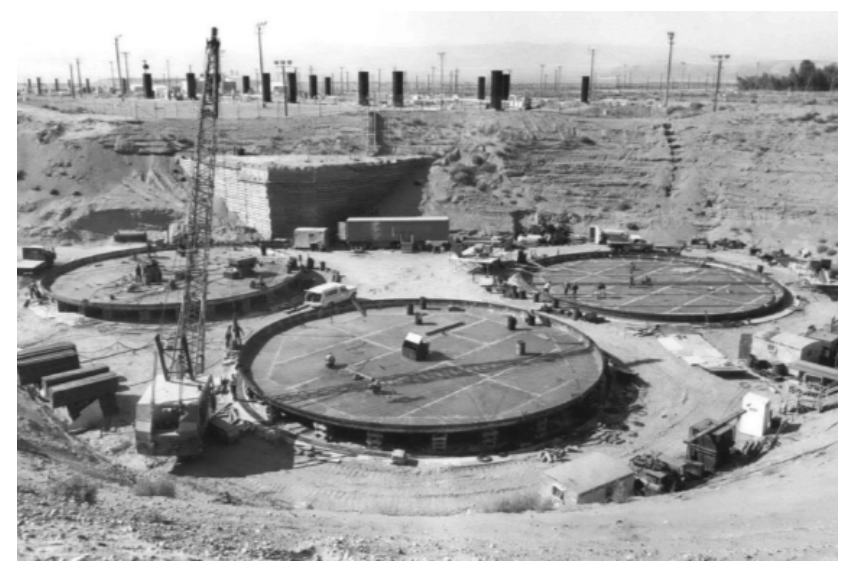

Figure 4-2. Crews Fabricating Secondary Liner Bottom (Photo 64775-12) (Taken 9-23-74) knuckles are made of 1/2 in. thick carbon steel. This is an increase in thickness over the 1/4 in. plate used in the 241-AY tank farm tanks. See Table 5-4, in Section 5.1, for weld NDE information.

Figure 4-2 shows the construction progress of the secondary liner for the 241-SY tank farm. Tanks SY-101 and SY-103 are resting on supports while tank SY-102 has been lowered onto the foundation. The individual plates were installed using fit-up tools to secure the plates within allowable tolerance for proper welding. Once completed and inspected, the secondary liner bottom was lowered onto the foundation using a series of eight hydraulic jacks around the 
perimeter of the tank bottom. A metal lip was installed around the upper edge of the bottom knuckle, which gave the hydraulic jacks a surface to use to lift and lower the tank bottom. Figure 4-3 shows the hydraulic jack and metal lip used as a lifting platform to lower the secondary liner onto the foundation. The liner welds were liquid-dye penetrant tested before and after lowering the secondary liner.

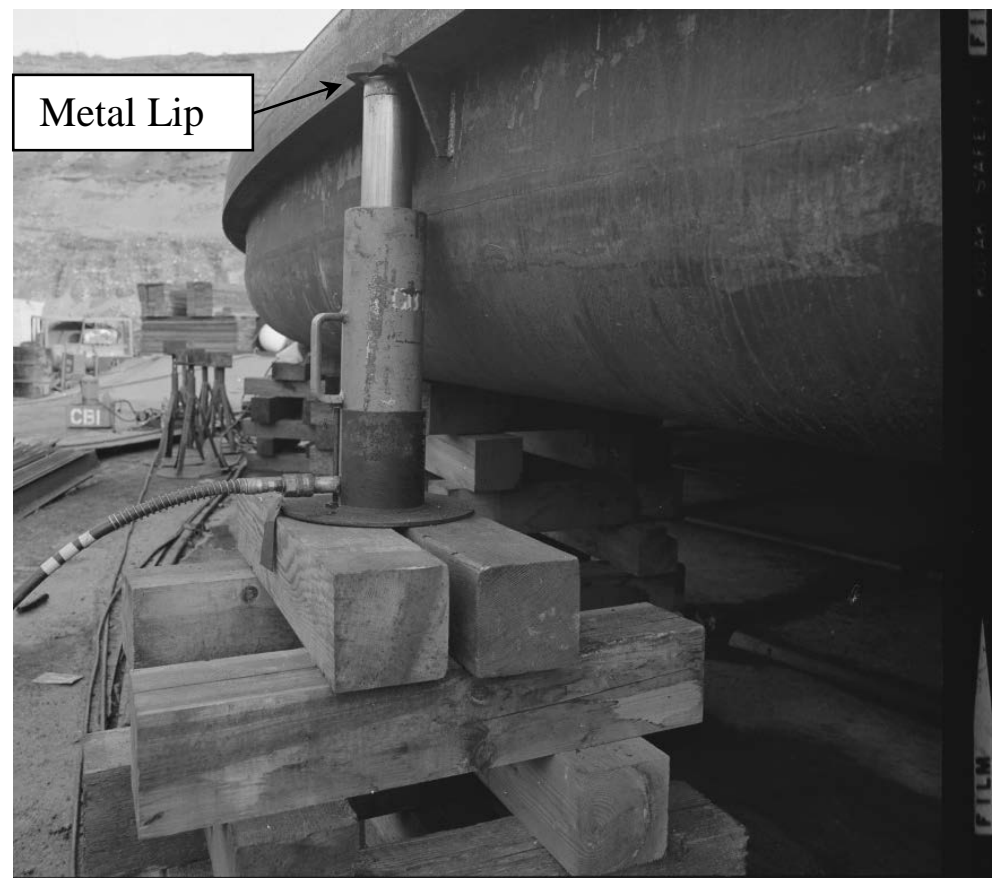

Figure 4-3. Lowering of Secondary Liner Bottom Using Hydraulic Jacks (Photo 66898-3) (Taken 12-9-1974)

Figure 4-4 shows a view of the tank SY-101 secondary liner lower knuckle construction. In the background, tank SY-102 is up on cribbing. The secondary liner bottoms for tanks SY-101 and SY-102 are resting on jack stands and cribbing, which were used to support the liner above ground level, allowing access to weld and inspect the underside of the liner bottoms. The 241SY tank farm used strong backs to support the liner bottoms

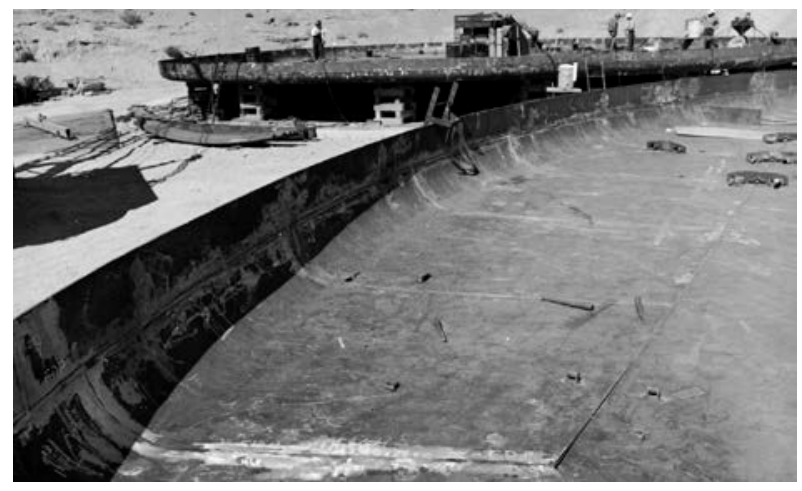
when they were being lowered.

Figure 4-4. Secondary Liner Lower Knuckle Section for Tank 241-SY-101 (Photo 64516-8) (Taken 8-20-74) 
The 241-AY tank farm used a superstructure to support the lowering operation, which provided more support ${ }^{4}$. For the 241-SY tank farm, additional strong backs were added to the lowering operations to limit deflections in the steel plates.

\subsection{REFRACTORY}

The refractory design used for the three 241-SY tank farm tanks specified a nominal 8 in. thick layer of LW50 castable refractory material to be located between the primary tank and secondary liner bottoms, manufactured by Pryor-Giggey. The primary purpose of the refractory was to act as an insulating barrier between the primary tank and the concrete foundation during the post-weld stress relief process where temperatures of up to $1100{ }^{\circ} \mathrm{F}$ were required in the primary tank. Its use was to prevent the structural concrete temperature from rising above $500^{\circ} \mathrm{F}$.

The refractory pad housed air ventilation piping, thermocouple conduit, and air distribution slots. The air distribution slots allowed airflow to cool the primary tank bottom and to direct potential leaks to the tank annulus where leak detectors were located (see H-2- 37705, Structural Insulating Concrete Plan and Details). The four ventilation pipes terminate at the center of the tank at an air distribution ring. Air is drawn through this ventilation piping and out through the air distribution slots in the refractory.

Prior to pouring the refractory a 7 in. $x 3 / 4$ in. carbon steel stiffener ring was installed around the perimeter of the pour and thermocouple conduits were installed. The stiffener ring was used as a form for the refractory and to contain spalling from the perimeter. The thermocouples allowed temperature monitoring of the refractory and primary tank bottom during post weld stress relief. The refractory was poured in twelve

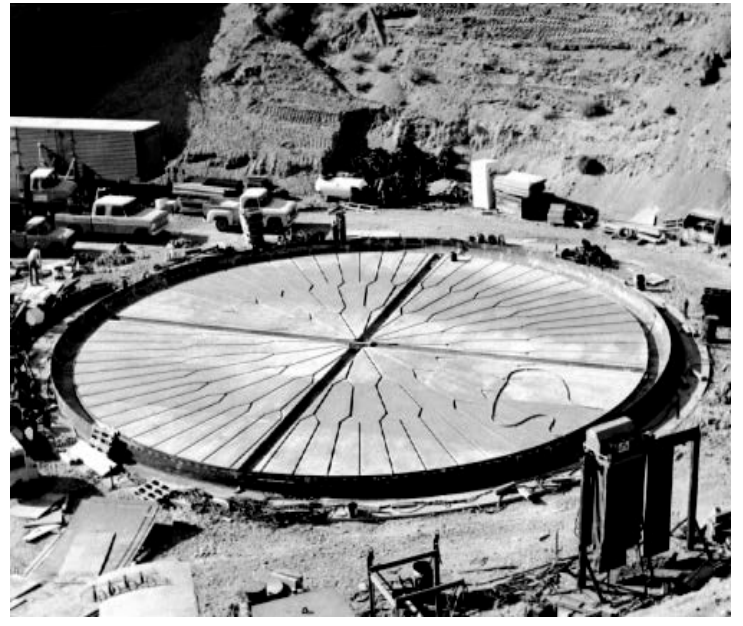

Figure 4-5. Tank SY-102 with Refractory Cut Out Over Air Ventilation Supply Pipes and Air Channels Cut into Refractory (Taken 10-21-74)

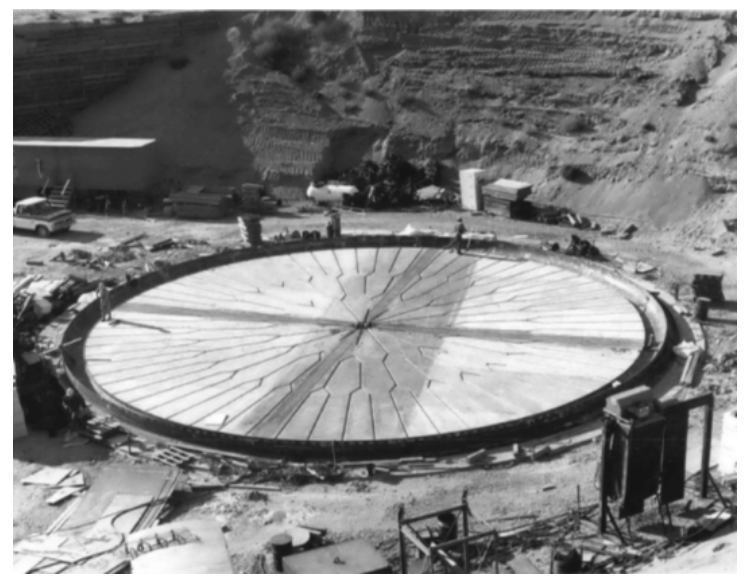

Figure 4-6. Tank 241-SY-102 with Refractory Filled in Over Air Ventilation Supply Pipes and Air Channels Cut into Refractory (Photo 66542-6) (Taken 10-22-74)

\footnotetext{
${ }^{4}$ The Pittsburgh Des Moines Steel Company used a more substantial superstructure for the construction of the 241-AZ tank farm than the one they used for 241-AY tank farm. (refer to RPP-RPT-54818 241-AZ Tank Farm Construction Extent of Condition Review for Tank Integrity)
} 
sections with channels left for the installation of the air supply pipes separately. The air distribution channels were cut into the refractory as opposed to the use of forms to shape the air channels in the 241-AY tank farm.

Following the installation of the ventilation piping and the center air distribution ring, refractory was poured into the pipe channels and air distribution channels were cut in these refractory sections. Figure 4-5 shows the refractory with the air ventilation supply pipe channel still open. Figure 4-6 shows the completed refractory of tank SY-102.

The refractory for tanks SY-101 and SY-102 was poured prior to the winter of 1974-75 and heated by a temporary electrical heating grid to prevent freezing. Installation of the refractory for tank SY-103 was postponed until March 1975 to avoid cold weather conditions. The primary tank and secondary liner construction continued during that time. A port was cut into the side of the secondary liner to support placement of the refractory in SY-

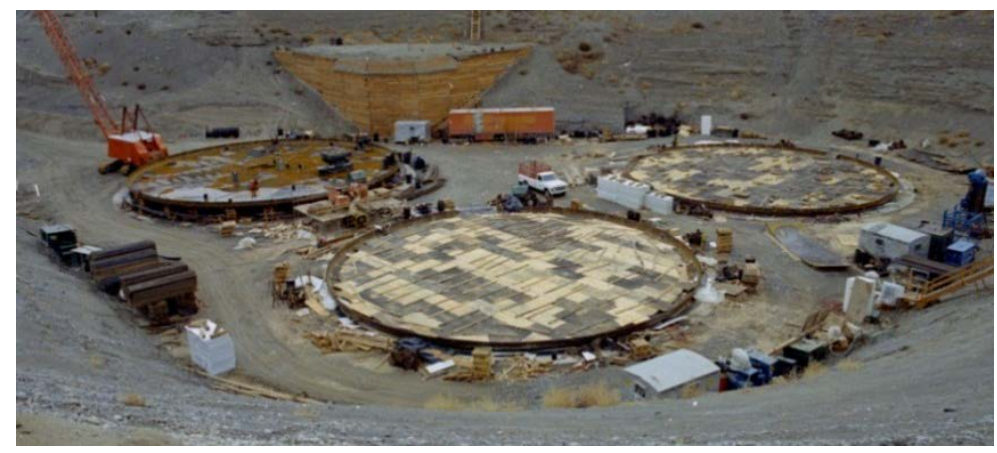

Figure 4-7. Protective Layer Installed Over Refractory for 241-SY-101 and 241-SY-102. (Photo 66534-1) (Taken 10-2174) 103. Figure $4-7$ shows the protective layer installed over tanks SY-101 and SY-102.

\subsection{PRIMARY TANK BOTTOM}

Following completion of the refractory pouring and cutting the air distribution channels, the primary tank bottom was fabricated using a similar sequence as the secondary liner bottom. A protective cover was installed over the refractory to prevent damage during primary tank bottom fabrication. The bottom plates were installed on jack stands and cribbing over the refractory using fit-up tools to allow proper welding. Once the top and bottom sides of the primary tank bottom were

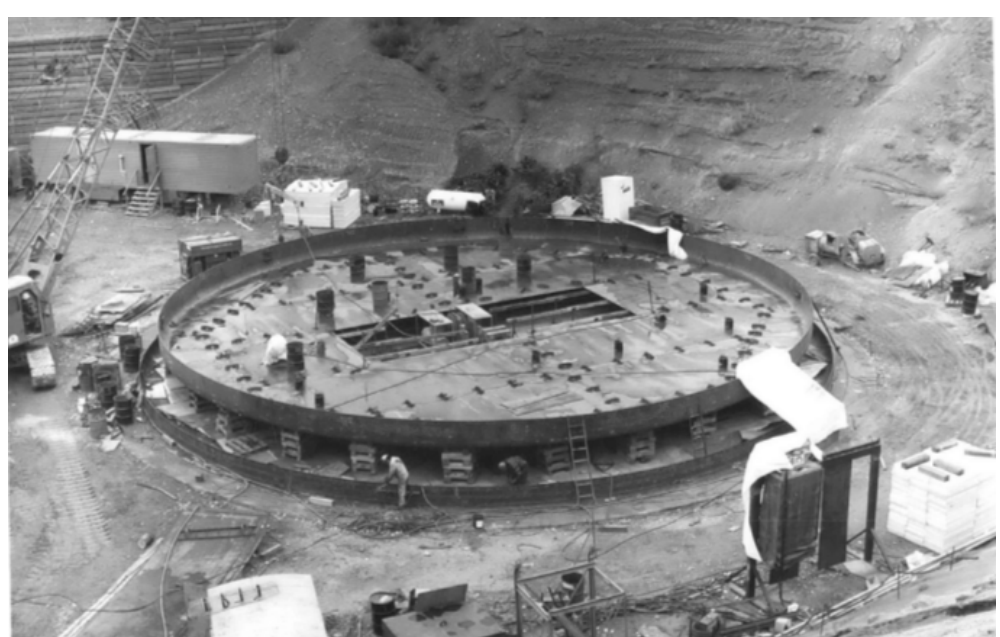

Figure 4-8. Crews Fabricating Primary Tank Bottom (Photo 66771-26) (Taken 11-21-74) completely welded, the first plate course (skirt) was welded on to the primary bottom and secondary liner. The primary tank was then lowered onto the refractory. 
The tank primary bottom is composed of primarily $1 / 2$ in. plate, increased from $3 / 8$ in. used in the 241-AY tank farm, with the exceptions of the center $4 \mathrm{ft}$. diameter which is composed of 1 in. thick steel plate, and a 7/8 in. thick plate used for the bottom knuckle. See Table 5-4, in Section 5.1, for weld NDE information. Figure 4-8 shows the construction progress of the primary tank bottom for 241-SY tank farm on November 21, 1974. Crews are fabricating the primary bottom using jack stands and cribbing to gain access to the bottom side.

\subsection{PRIMARY TANK WALL AND TANK DOME}

The primary tank measures 75 feet in diameter to the center of the vertical plate. While the vertical wall of the secondary liner

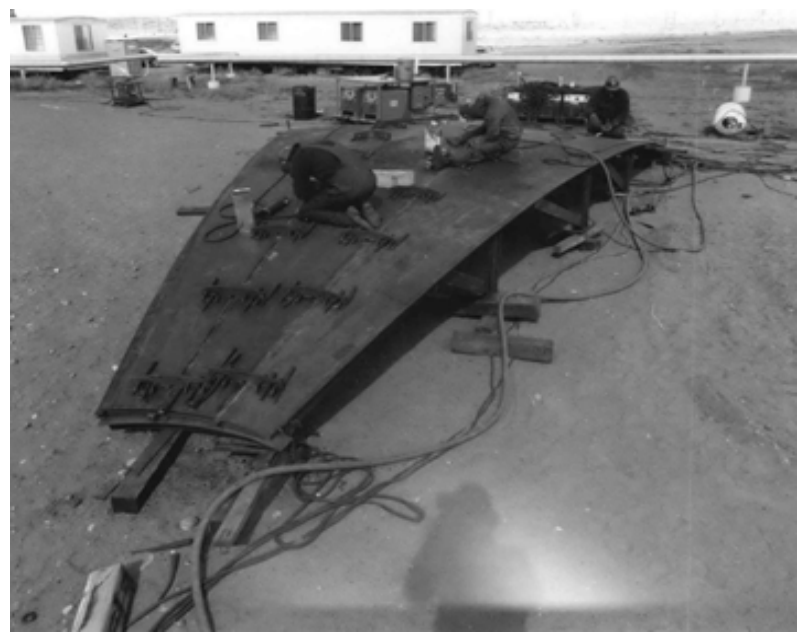

Figure 4-9. Fabricators Welding the Tank Dome Sub-Assemblies (Photo 67722-39) (Taken 3-20-75) is all $3 / 8$ in. thick steel, the primary tank plate thickness varies from $7 / 8 \mathrm{in}$. thick carbon steel at the bottom knuckle to 3/8 in. thick at the top transition plate and top knuckle. Above the bottom knuckle and bottom transition plates, there are three courses of plates that make up the majority of the primary tank wall as seen in Figure 3-1. The first of these courses is 3/4 in. thick. The next two courses are 1/2 in. thick. Above the third course is a 3/8 in. thick plate referred to as the top transition. This top transition plate is butt welded to a 3/8 in. thick primary top knuckle, which begins the elliptical shape of the steel tank dome. See Table 5-4, in Section 5.1, for weld NDE information.

To facilitate the installation of tank dome plates, a temporary center support post was installed. This post provided a resting place for the tank dome plates for proper fit-up and welding. Several smaller dome sections were welded together on supports at grade level, before being lifted by a crane and weld in place. Welders can be seen welding tank dome sub-assemblies in Figure 4-9. Figure 4-10 shows the dome support column.
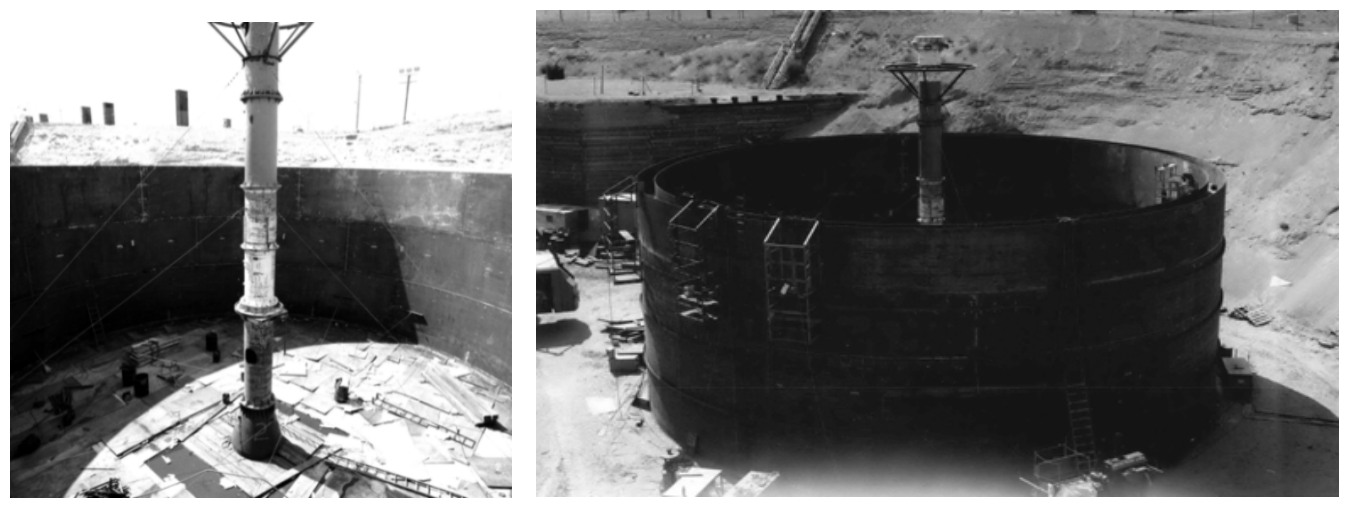

Figure 4-10. Tank Dome Support (Photo 68847-35 and 68847-38) (Taken 4/18/75) 
After installation of the dome plates, the riser penetration holes were cut and pipes were welded to the tank dome plates. These penetrations served as access points for the remainder of construction and they support the installation of permanent and temporary equipment during operation. Figure 4-11 shows the construction progress of tank SY103 primary and secondary liner wall.

\subsection{SECONDARY LINER WALL AND CONCRETE SHELL}

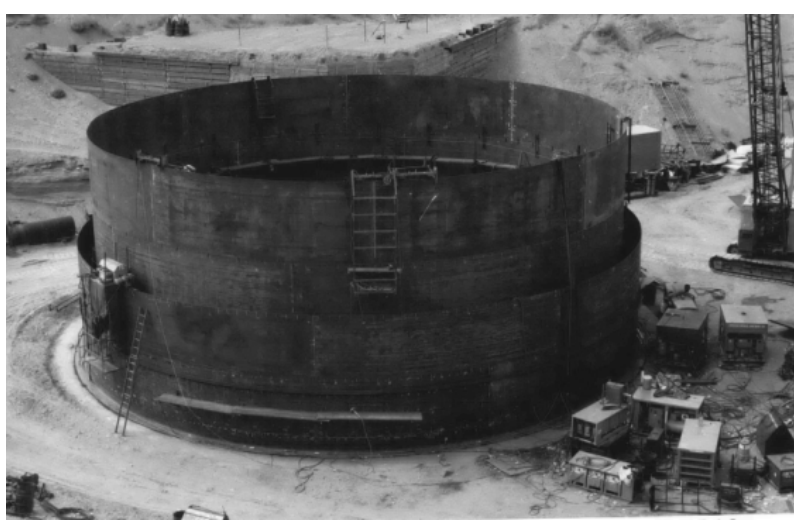

Figure 4-11. Secondary Liner Wall Fabrication and Primary Tank Wall (Photo 68847-37)

(Taken 4-18-75)

The secondary liner wall is made up of a four plate course, seen in Figure 4-12 similar to the primary tank wall. The 3/8 in. thick secondary liner wall was welded up to the elevation just below the secondary top knuckle. The top knuckle of the secondary liner was not installed until after weld inspections, stress relieving, and hydrostatic testing of the primary tank were completed to allow access into the annulus.

The concrete shell, poured directly against the secondary liner (i.e., the secondary liner was used as a casting form for the concrete shell), is 1-1/2 ft. thick and has an outside diameter of 83 $\mathrm{ft}$. The vertical concrete wall rests on a steel bearing plate that sits in a groove cast in the foundation. The vertical wall of the concrete shell was poured in three courses. Figure 4-13 shows the construction progress of the concrete vertical wall for the 241-SY tank farm on June 19, 1975. Two courses of concrete have been poured.

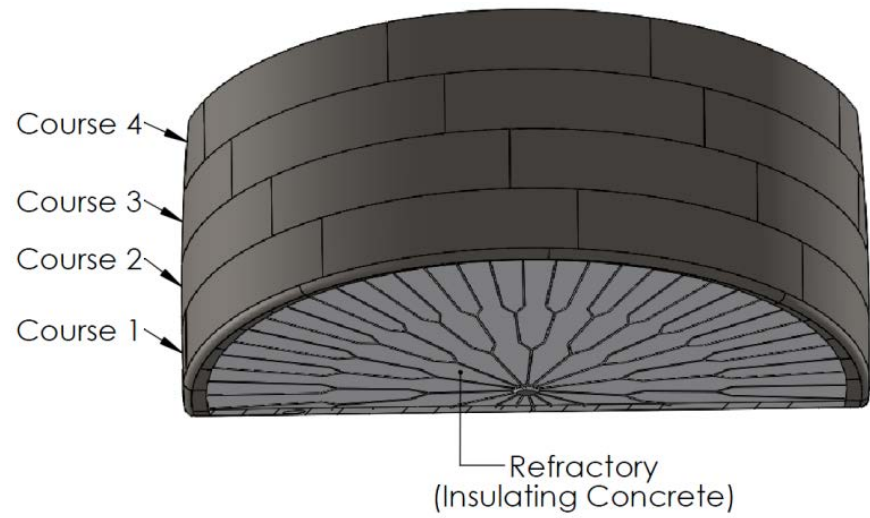

Figure 4-12. Cross-Section of Primary Tank and Refractory Backfilling to the top of the concrete, hydrostatic testing, and post-weld stress relieving were completed prior to the final course and tank dome concrete being poured.

\subsection{PRIMARY TANK STRESS RELIEVING}

After installation of the risers, and removal of the center post, the primary tanks were post-weld stress relieved. Insulation was installed over the primary tank and in the annulus to protect the concrete from high temperatures and to help regulate the heating of the primary tank. The refractory installed between the secondary liner bottom and the primary tank bottom protected the concrete foundation from high temperatures. In Figure 4-14, the crew is preparing for postweld stress relieving. The insulation used to retain heat and protect the concrete can be seen wrapped around the primary tank of SY-102 on June 19, 1975. 
The requirements for stress relieving were in accordance with ASME Code, Section VIII (1971), which specified a holding temperature of $1100{ }^{\circ} \mathrm{F}$ for 1 hour for each inch of steel. In addition, the difference between the maximum and minimum temperatures in the tank was required to be less than $200{ }^{\circ} \mathrm{F}$. Thermocouples were attached to the primary tank to measure the temperature. The thermocouples installed during the insulating refractory pour were used to monitor the progress of the tank post-weld stress relieving temperatures in the primary bottom. The post-weld stress relieving specification from B-101-C1 is as follows:

a. "Primary tanks are to be fully stress relieved following completion of all high temperature work such as welding, cutting, burning, gouging, etc. Tanks are to be heated

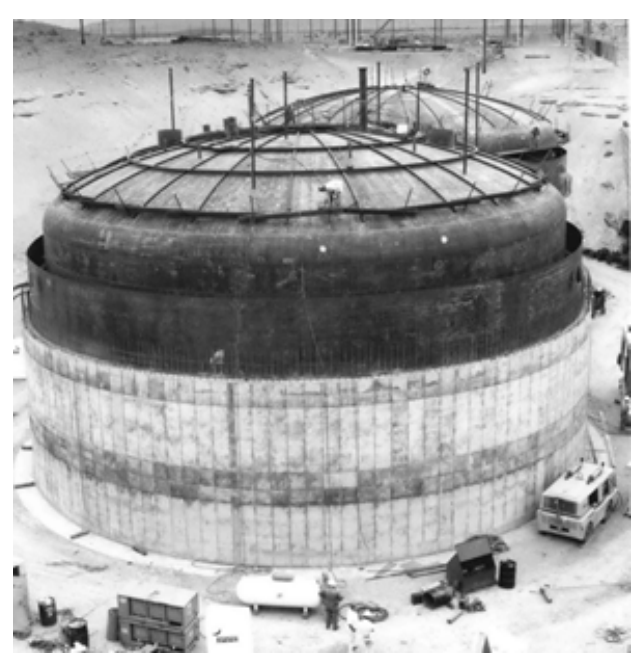

Figure 4-13. Two Courses of Concrete Have Been Poured (Photo 69402-38)

(Taken 6-19-75) internally and indicating and recording temperature devices shall be used to aid in control and maintenance of a uniform distribution of temperature in the tank walls. Tanks shall be insulated for the stress relieving operation; insulation shall be removed after completion of stress relieving.

b. Stress relieving shall be in accordance with Paragraph UCS-56, Section VIII, of the ASME Boiler and Pressure Vessel Code, except that:

(1) With reference to Note 1, Table UCS-56 tabulation, the minimum allowable holding temperature shall be $1000 \mathrm{~F}$.

(2) The rate of temperature rise and reduction between $600 \mathrm{~F}$ and $1000 \mathrm{~F}$ shall be no more than $100 \mathrm{~F}$, per hour.

(3) The period of heating from $600 \mathrm{~F}$ to $1100 \mathrm{~F}$ shall consume no more than 12 hours.

(4) During the heatingup period, above 600 $F$, the temperature of all parts of the tank being heated shall be uniform with a maximum temperature differential at any

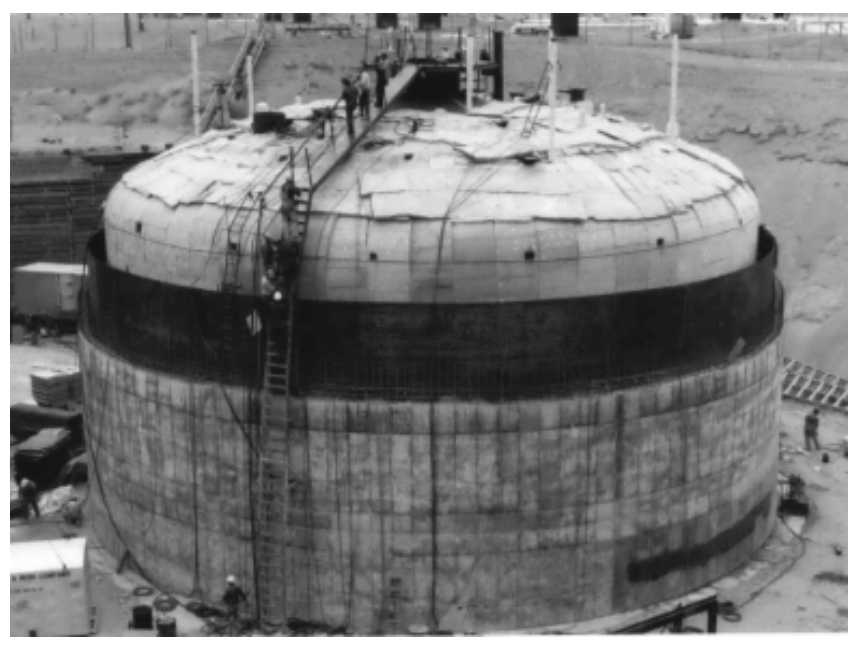

Figure 4-14. Insulation Covering the Primary Tank of SY-102 Prior to Stress Relieving (Photo 69402-39) (Taken 6-19-75) time, between the highest and lowest temperature, of 200 F” 
The heating occurred in two phases; the tank was first heated to $600^{\circ} \mathrm{F}$ and held for 2 hours to complete the curing process on the refractory. This curing was done to dehydrate the refractory and effectively turn it into a ceramic material. After the 2 hour hold, the temperature was to be slowly increased to $1100^{\circ} \mathrm{F}$ where it was held for 1 hour.

The tanks were cooled to $600^{\circ} \mathrm{F}$ at a rate of no more than $100^{\circ} \mathrm{F}$ per hour. At that point the, the stress relieving was deemed complete and the recorders documenting the heating and cooling were turned off. Table 4-1 shows a summary of the stress relieving of the tanks in the 241-SY tank farm.

Table 4-1. Post Weld Stress Relieving in 241-SY Tank Farm

\begin{tabular}{|c|c|c|c|}
\hline Event & SY-101 & SY-102 & SY-103 \\
\hline Burners Turned On & $\begin{array}{l}\text { 2:00 p.m. } \\
\text { July } 10,1975\end{array}$ & $\begin{array}{l}\text { 5:00 p.m. June 21, } \\
1975\end{array}$ & $\begin{array}{c}\text { 10:00 a.m. } \\
\text { August } 1,1975\end{array}$ \\
\hline $\begin{array}{l}\text { Completed Initial Hold } \\
\text { Time to Cure Refractory }\end{array}$ & $\begin{array}{l}\text { 5:30 a.m. } \\
\text { July } 11,1975\end{array}$ & $\begin{array}{c}\text { 3:30 p.m. June 22, } \\
1975\end{array}$ & $\begin{array}{c}\text { 10:00 p.m. } \\
\text { August 1, } 1975\end{array}$ \\
\hline \multirow{2}{*}{$\begin{array}{l}\text { Completed Final Hold } \\
\text { Time for Post-Weld } \\
\text { Stress Relief }\end{array}$} & $\begin{array}{l}\text { 12:10 a.m. } \\
\text { July } 12,1975\end{array}$ & $\begin{array}{l}\text { 11:42 a.m. June 23, } \\
1975\end{array}$ & $\begin{array}{c}\text { 3:00 p.m. } \\
\text { August 2, } 1975\end{array}$ \\
\hline & $\begin{array}{l}\text { Three Hour Hold at } \\
1000^{\circ} \mathrm{F}\end{array}$ & $\begin{array}{l}\text { One Hour Hold at } \\
1100^{\circ} \mathrm{F}\end{array}$ & $\begin{array}{l}\text { One Hour Hold at } \\
1100^{\circ} \mathrm{F}\end{array}$ \\
\hline $\begin{array}{l}\text { All Thermocouples } \\
\text { Reading Below } 600^{\circ} \mathrm{F} \text {, } \\
\text { Reorders Turned Off. }\end{array}$ & $\begin{array}{c}\text { 8:10 a.m. July 12, } \\
1975\end{array}$ & $\begin{array}{c}\text { 7:30 p.m. June 24, } \\
1974\end{array}$ & $\begin{array}{c}\text { 11:20 p.m. } \\
\text { August 2, } 1974\end{array}$ \\
\hline
\end{tabular}

The post-weld stress relieving process for tank SY-101, the second tank constructed in 241-SY tank farm, was started at 2:00 p.m. on 7/10/1975. An initial holding temperature of $600^{\circ} \mathrm{F}$ was reached at 3:30 a.m. on 7/11/1975, and completed 2 hours later at 5:30 a.m. The final hold temperature for tank SY-101 was $1000^{\circ} \mathrm{F}$ and it was reached at 9:10 p.m. on 7/11/1975. It should be noted that the temperature increase from $600^{\circ} \mathrm{F}$ to $1100^{\circ} \mathrm{F}$ should have taken no more than 12 hours (see B-101-C1). In this case it took approximately 15.5 hours. There was no mention of this issue in the QA logs and no NCR's or deficiency reports were located. The temperature was held at $1000^{\circ} \mathrm{F}$ for 3 hours before the heat was reduced and finally turned off. Post-weld stress relieving in tanks SY-101 was completed at 8:10 a.m. on 7/12/1975. At this time, all of the thermocouples had cooled below $600^{\circ} \mathrm{F}$.

Official startup of stress relieving on tank SY-102 was at 3:00 p.m. on 6/21/1975; all burners were turned on at 5:00 p.m. A 2 hour hold at $600^{\circ} \mathrm{F}$ occurred at approximately 3:30 p.m. on 6/22/1975. A temperature of $1100^{\circ} \mathrm{F}$ was reached at 10:42 a.m. on 6/23/1975 and held for 1 hour. It took approximately 19 hours to heat tank SY- 102 from $600^{\circ} \mathrm{F}$ to $1100^{\circ} \mathrm{F}$, or 7 hours longer than specified in specification B-101-C1. There was no mention of this issue in the QA logs, and no NCR's or deficiency reports were located. After the 1 hour hold, the temperature 
was slowly reduced until the recorders were shut off at 7:30 a.m. on 6/24/1975 because all of the thermocouples were below $600{ }^{\circ} \mathrm{F}$.

Official startup of stress relieving on tank SY-103 was at 10:05 a.m. on 8/1/1975. The $600^{\circ} \mathrm{F}$ curing temperature was reached at 8:00 p.m. and held for 2 hours. The stress relieving temperature of $1100^{\circ} \mathrm{F}$ was reached at 2:00 p.m. on 8/2/1975 and the hold was completed 1 hour later at 3:00 p.m. The temperature increase from $600^{\circ} \mathrm{F}$ to $1100^{\circ} \mathrm{F}$ took 16 hours, which is longer than the 12 hours specified in specification B-101-C1. There was no mention of this issue in the QA logs, and no NCR's or deficiency reports were located. The temperature was slowly reduced until the recorders were shut off at 11:30 p.m. on 8/2/1975.

Stress relieving was successful in all tanks, and there were no difficulties with the stress relieving process or equipment noted in the QA logs. Tank SY-101 was stress relieved at only $1000^{\circ} \mathrm{F}$ for 3 hours. There is no supplemental information or documentation on why it was stress relieved for 3 hours at $1000^{\circ} \mathrm{F}$ and not at $1100^{\circ} \mathrm{F}$ for 1 hour. All tanks in the 241-SY tank farm took longer than the 12 hours allowed in the specification for heating from $600^{\circ} \mathrm{F}$ to $1100^{\circ} \mathrm{F}$. There was no mention of this issue in the QA logs, and there were no NCR's or deficiency reports located.

\subsection{PRIMARY TANK HYDROSTATIC TEST}

After completion of stress relieving, the heating equipment and temporary insulation were removed. The primary tank was then subjected to hydrostatic testing. Section 16, "Hydrostatic Test,” of B-101-C1, provided the following direction for hydrostatic testing:

a. "After the tank has been stress relieved, a full hydrostatic test shall be applied to the primary tanks by filling with water to a depth of 39 feet from the bottom of the tank \pm 1 inch. One of the vertical risers near the center of the tank dome shall be used for introduction of water. Air bleed ports shall be provided to evacuate air within from the other vertical risers during the test. All accessible welded joints below the water level shall be coated with blue chalk. A preliminary hydrostatic test may be made, before stress relieving, at the contractor's option

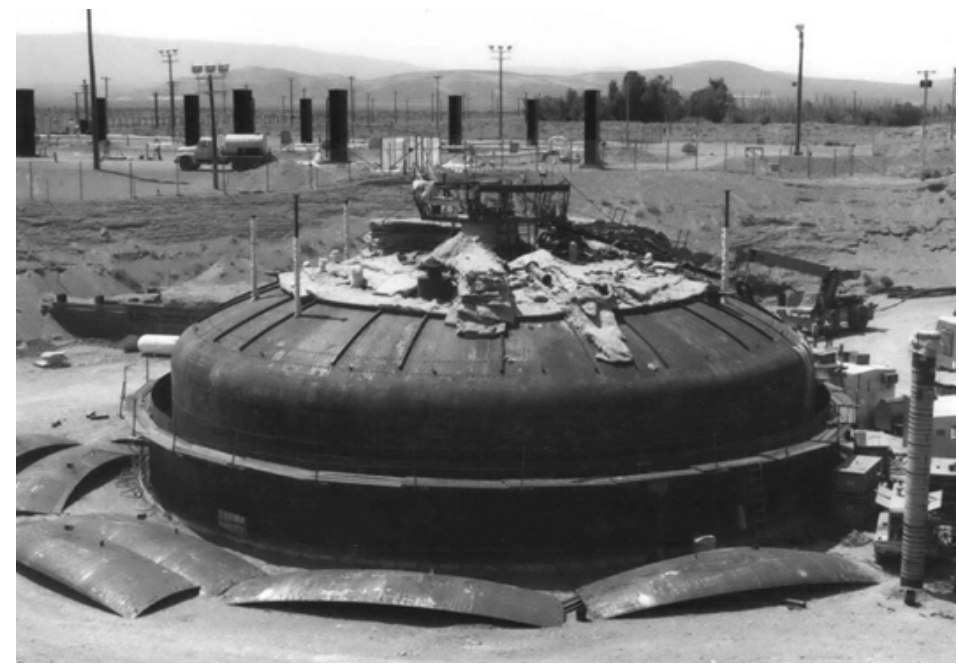

Figure 4-15. Partial Backfill of Tank SY-103 (Photo 69620-44) (Taken 7-22-75)

b. The hydrostatic pressure shall be maintained for 24 hours. 
c. Leak detection shall be by visual inspection of each welded joint previously coated with a solution of blue chalk and water or alcohol."

Official startup of hydrostatic testing on tank SY-101 was on 7/24/1975 with the start of tank filling and covering weld seams with chalk. Testing was completed on 7/25/1975 with no leaks noted.

Official startup of hydrostatic testing on tank SY-102 was on 7/9/1975 with the start of tank filling. Progression of hydrostatic testing was slowed by the stress relieving effort in tank SY101. Testing was completed on 7/15/1975 with no leaks noted.

Official startup of hydrostatic testing on tank SY-103 was on 8/8/1975 with the start of tank filling and covering weld seams with chalk. Progression of hydrostatic testing was slowed by the attempted strain gauge testing on the primary bottom of tank SY-103. Testing was completed on 8/11/1975 with no leaks noted. Additional hydrostatic testing was performed on this tank to support the strain gauge and acoustic testing of the stress from the bulge in tank bottom (see section 5.2.2.3).

After the completion of stress relieving and hydrostatic testing, the tanks were backfilled to the top of the already-poured concrete shell.

Figure 4-15 shows the construction progress for tank SY-103 on July 22, 1975. Post-weld stress relieving and partial backfill are complete. The secondary liner top knuckles are spread around the tank and ready to be lifted into place and welded to the secondary liner vertical wall.

\subsection{COMPLETE SECONDARY LINER WALL AND TANK PENETRATIONS}

Once the hydrostatic test was completed, the need for further access into all portions of the annulus was limited. The secondary top knuckle was installed and welded to the secondary liner vertical wall section. The secondary top knuckle is not welded to the primary tank. By design, a 1 in. maximum gap exists between the primary

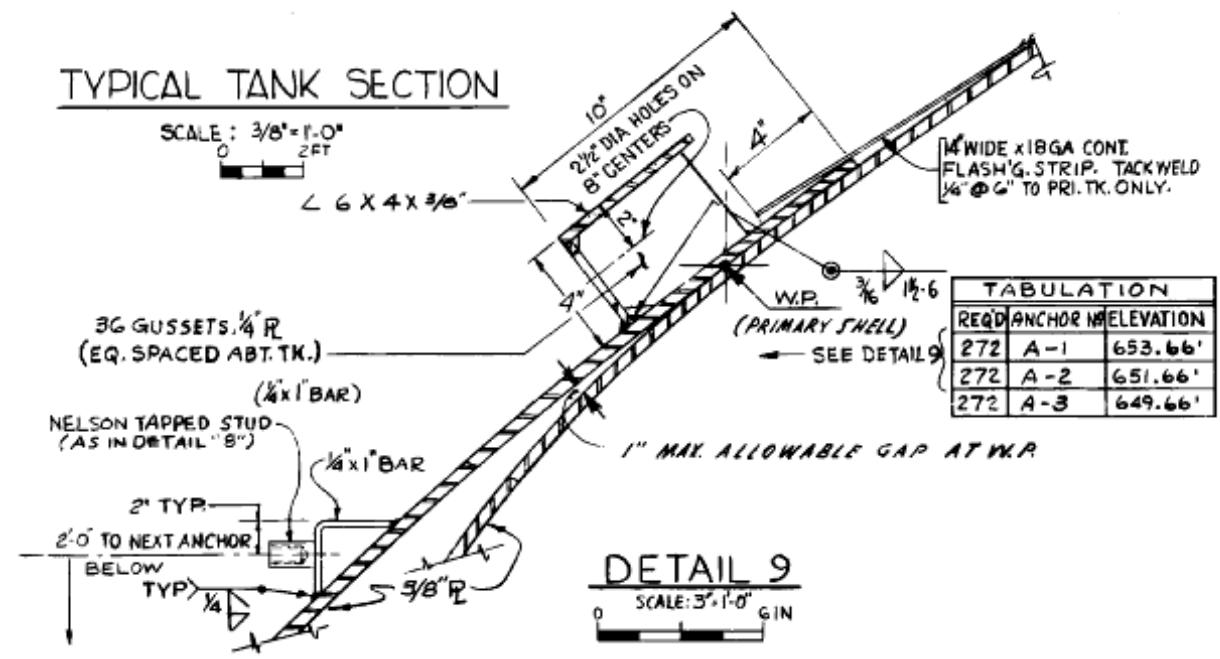

Figure 4-16. Detail 9 From H-2-37772, Showing the Intersection Between the Secondary Liner and Primary Tank Dome 
tank dome and termination of the secondary liner. To prevent the collection of debris or concrete during the remaining construction, metal flashing was installed over the outside of the secondary top knuckle by tack welding to the outside of the primary tank as shown in drawing H-2-37772, Detail \#9 in Figure 4-16.

\subsection{CONCRETE DOME POUR}

Section 17 "Support of Tanks During Concreting” of B-101-C1, provided the following direction to support concrete pours:

a. "Tank supports shall be provided by the contractor to maintain the tanks in the geometric shape shown on the drawings during the period while the wall and dome concrete is being placed. The secondary tanks will be used as the inside form for the concrete walls.

b. Supports for placement of dome concrete shall be so located that steel tank dome does not deflect more than 1" between supports or exceed a stress of 20,000 psi at any point. Placement of dome concrete shall not impose any additional load on the primary tank shell.

c. Concrete and concrete reinforcing steel will be furnished and placed by another contractor. Placement of concrete will be limited to a rate of not more than 2 feet in elevation per hour from the bottom of the wall to a point 2 feet above the tangent line of the dome. Concrete in the haunch area, to the construction joint approximately 9 feet in from the outer wall form, will be placed at a rate not greater than one foot in elevation per hour. After concrete in the haunch area has cured a minimum of 3 days, concrete in remainder of the dome will be placed in one continuous pour. The following are the wet concrete live loads to be imposed on the tank:

\section{Within Radius of Tank Center (ft)}

$$
\begin{gathered}
0^{\prime}-25^{\prime} \\
25^{\prime}-37^{\prime} \\
37^{\prime}-40^{\prime}
\end{gathered}
$$$$
\text { Tank Wall }
$$

\section{Load (Lbs. per Sq. Ft.)}

375
450
450 at 37 ' radius to 1,100 at 40 ' radius
600
to 1,100 at 40 ' radius

d. High-early-strength cement will be used in concrete above the tangent line of the tank domes to permit earlier access to tank interiors and completion of tank appurtenances. Concrete will have a slump of not more than 4 inches at the time of placement and a minimum compressive strength of 3000 psi in 28 days.

e. Shoring or external support shall be of such design and construction, that when the dome concrete is placed, no additional load will be placed on the shell of the primary tank. 
f. Tank dome supports shall remain in place a minimum of 7 days after completion of the final placement of concrete in the tank dome, except that the center support shall remain in place 14 days.

g. The floor of the primary tank shall be covered with 5/8 inch plywood or one inch thick lumber to prevent the accidental reconcentration (sic) of stresses removed during stress relief. Dome support columns shall be designed to rest on blocks or heavy timbers which will aid in distributing the load.

A significant amount of rebar was installed around the tank prior to pouring the concrete. The rebar was used to reinforce the concrete. In Figure 4-17, the crew is installing rebar in the dome region while concrete forms are in place just below the tank haunch.

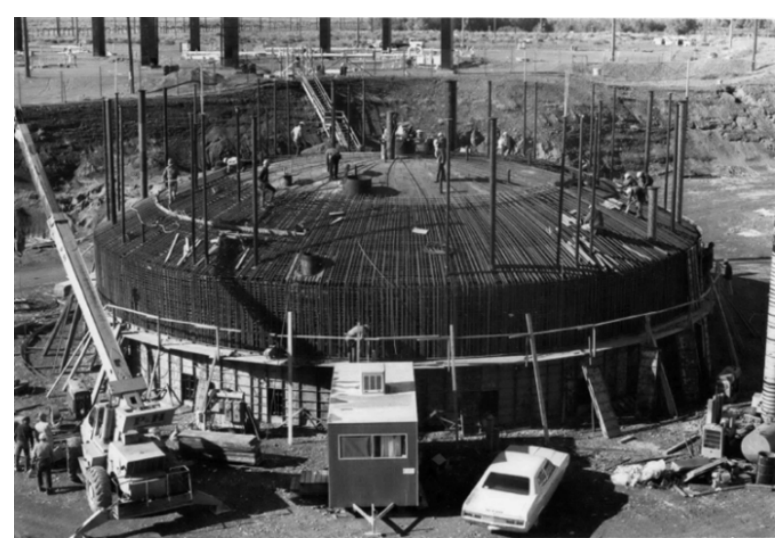

Figure 4-17. Crews Installing Rebar Prior to Concrete Dome Pour (Photo 70273-26) (Taken 10-22-75)

The dome was poured in two sections joined using a keyed construction joint. The first section poured includes the rest of the vertical wall and haunch. The tank haunch is the transition between the vertical concrete shell and tank dome. The second section was the remainder of the dome.

Figure 4-18 shows the construction progress of the concrete pour for the 241-SY tank farm on October 22, 1975. The last three sections of concrete have been poured and the concrete shell is completed.

\subsection{TANK APPURTENANCES}

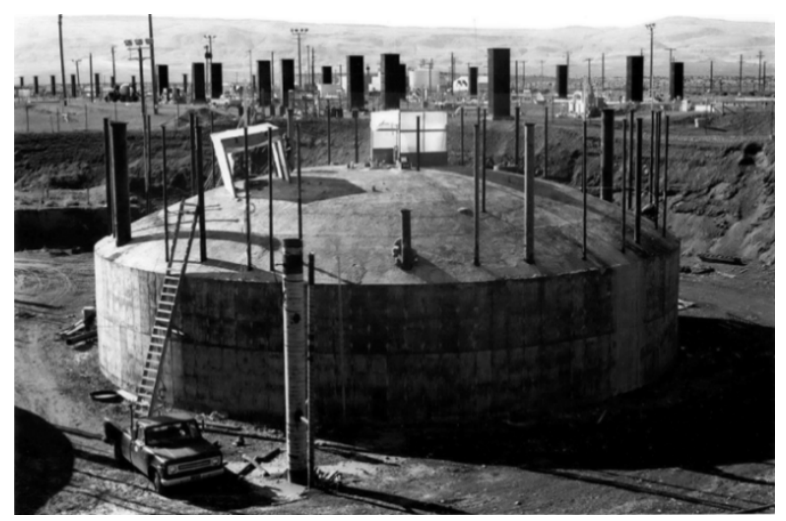

Figure 4-18. Completion of Tank Dome Concrete (Photo 70273) (Taken 10-22-75)

After completing the concrete pours, the tank dome support structures were disassembled and removed in pieces through the existing 42 in. diameter riser penetrations. The equipment to be placed in the interior of the tank was then installed, including thermocouples, dry wells, and annulus pump pit, leak detection pump pit drains, and an air lift circulator in tank SY-102. These pieces of equipment were welded to the existing penetrations that had previously been installed on the tank dome prior to the tank stress relief. 


\subsection{CONSTRUCTION ISSUES}

This section provides a detailed view of the construction issues identified during the fabrication of tanks SY-101, SY-102, and SY-103. This information has been compiled from a review of the Quality Assurance (QA) Construction daily logbooks (QA log), inspection sheets, memos, drawings, photos, construction records, and post-construction reports. The most important construction deficiencies are listed in Table 5-1 below. As noted in Section 4.0, tank SY-102 was built first, followed by SY-101, and with SY-103 last. The secondary and primary tank bottom fabrication/testing, post-weld stress relief and the refractory condition were the focus of this review.

Table 5-1. 241-SY Tank Farm Major Non-Conformance/Deficiency Report List

\begin{tabular}{|c|c|c|c|}
\hline $\begin{array}{l}\text { Non-Conformance or Design } \\
\text { Change }\end{array}$ & Date & Tank & Description \\
\hline NCR: B-101-20-2307-6 & $9 / 20 / 1974$ & SY-102 & $\begin{array}{l}\text { In several areas of the tank SY- } 102 \text { secondary } \\
\text { bottom, the root to crown slope exceeds the } \\
3 / 8 \text { inches per foot allowable. Thus the tank } \\
\text { bottom presently exhibits slopes in localized } \\
\text { areas up to } 5 / 8 \text { inches per foot. }\end{array}$ \\
\hline NCR: B-101-21-2307-7 & 9/20/1974 & SY-102 & $\begin{array}{l}\text { In two areas of the tank SY-102 secondary } \\
\text { bottom distortions exist within the tangent } \\
\text { point of the knuckle curvature. }\end{array}$ \\
\hline NCR: B-101-22-2307-8 & 10/1/1974 & SY-101 & $\begin{array}{l}\text { In several areas of the tank SY-101 secondary } \\
\text { bottom, the root to crown slope exceeds the } \\
3 / 8 \text { inches per foot allowable. Thus, the tank } \\
\text { bottom presently exhibits slopes in localized } \\
\text { areas up to } 13 / 16 \text { inches per foot. }\end{array}$ \\
\hline NCR: B-101-24-2307-9 & $12 / 13 / 1974$ & SY-103 & $\begin{array}{l}\text { In several areas of the tank SY-103 secondary } \\
\text { bottom, the root to crown slope exceeds the } \\
3 / 8 \text { inches per foot allowable. Thus, the tank } \\
\text { bottom presently exhibits localized areas up } \\
\text { to } 1 \text { inch per foot. }\end{array}$ \\
\hline NCR: B-101-34-2307-19 & $3 / 20 / 1975$ & SY-103 & $\begin{array}{l}\text { In several areas of the tank SY-103 primary } \\
\text { bottom, the root to crown slope exceeds the } \\
3 / 8 \text { inches per foot allowable. Thus, the tank } \\
\text { bottom presently exhibits slopes in localized } \\
\text { areas up } 13 / 16 \text { inch per foot. }\end{array}$ \\
\hline Design Change: B-101-128 & $1 / 31 / 1977$ & SY-101 & $\begin{array}{l}\text { Grout out-of-tolerance bumps in the primary } \\
\text { tank bottom of the SY-101 tank. Locations at } \\
\text { approximately } 0^{\circ} \text { and } 180^{\circ} \text { (North and South) } \\
\text { on the tank. }\end{array}$ \\
\hline
\end{tabular}




\subsection{WELD REJECTION AND NON-DESTRUCTIVE EXAMINATION}

A quantitative comparison of welding success on tanks SY-101, SY-102, and SY-103 is shown in Table 5-2. A similar comparison was completed and included within RPP-ASMT-53793, Tank 241-AY-102 Leak Assessment Report, for the 241-AY tank farm. Analysis of the tank AY101 and tank AY-102 primary bottom radiographic test diagrams (weld maps) was completed for a second time as a part of this extent of condition effort to ensure accuracy and consistency. The results are provided in Table 5-3, "241-AY Tank Farm Primary Tank Bottom Weld Comparison.” They are nearly identical to those previously tabulated with some minor discrepancies resulting from omission of the center dollar plate in the primary tank bottom in RPP-ASMT-53793.

Table 5-2. 241-SY Tank Farm Primary Tank Bottom Weld Comparison

\begin{tabular}{|c|c|c|c|c|c|c|c|c|c|}
\hline & \multicolumn{3}{|c|}{ Tank SY-101 } & \multicolumn{3}{|c|}{ Tank SY-102 } & \multicolumn{3}{|c|}{ Tank SY-103 } \\
\hline & $\begin{array}{l}\text { Feet of } \\
\text { Weld } \\
\text { (ft) }\end{array}$ & $\begin{array}{c}\text { Reject } \\
\text { Rate } \\
(\%) \\
\text { per } \\
\text { Repair } \\
\text { Cycle }\end{array}$ & $\begin{array}{c}\text { Total } \\
\text { Reject } \\
\text { Rate } \\
(\%)\end{array}$ & $\begin{array}{c}\text { Feet of } \\
\text { Weld } \\
\text { (ft) }\end{array}$ & $\begin{array}{c}\text { Reject } \\
\text { Rate } \\
(\%) \\
\text { per } \\
\text { Repair } \\
\text { Cycle }\end{array}$ & $\begin{array}{c}\text { Total } \\
\text { Reject } \\
\text { Rate } \\
(\%)\end{array}$ & $\begin{array}{c}\text { Feet of } \\
\text { Weld } \\
\text { (ft) }\end{array}$ & $\begin{array}{c}\text { Reject } \\
\text { Rate } \\
(\%) \\
\text { per } \\
\text { Repair } \\
\text { Cycle }\end{array}$ & $\begin{array}{c}\text { Total } \\
\text { Reject } \\
\text { Rate } \\
(\%)\end{array}$ \\
\hline $\begin{array}{l}\text { Weld prior } \\
\text { inspection }\end{array}$ & 655 & $\mathrm{~N} / \mathrm{A}$ & $\mathrm{N} / \mathrm{A}$ & 625 & $\mathrm{~N} / \mathrm{A}$ & $\mathrm{N} / \mathrm{A}$ & 647 & $\mathrm{~N} / \mathrm{A}$ & N/A \\
\hline $\begin{array}{l}\text { Weld rejected } \\
\text { after original weld }\end{array}$ & 189 & $28.9 \%$ & $28.9 \%$ & 130 & $20.8 \%$ & $20.8 \%$ & 184 & $28.4 \%$ & $28.4 \%$ \\
\hline $\begin{array}{l}\text { Weld rejected } \\
\text { after first repair }\end{array}$ & 71 & $37.6 \%$ & $30.8 \%$ & 30 & $23.1 \%$ & $21.2 \%$ & 29 & $15.8 \%$ & $25.6 \%$ \\
\hline $\begin{array}{l}\text { Weld rejected } \\
\text { after second } \\
\text { repair }\end{array}$ & 21 & $29.6 \%$ & $30.7 \%$ & 11 & $36.7 \%$ & $21.8 \%$ & 8 & $27.6 \%$ & $25.7 \%$ \\
\hline $\begin{array}{l}\text { Weld rejected } \\
\text { after third repair }\end{array}$ & 1 & $4.8 \%$ & $30.1 \%$ & 4 & $36.4 \%$ & $22.0 \%$ & 1 & $12.5 \%$ & $25.6 \%$ \\
\hline $\begin{array}{l}\text { Weld rejected } \\
\text { after fourth repair }\end{array}$ & 0 & $0.0 \%$ & $30.1 \%$ & 0 & $0.0 \%$ & $22.0 \%$ & 1 & $100.0 \%$ & $25.7 \%$ \\
\hline $\begin{array}{l}\text { Weld rejected } \\
\text { after fifth repair }\end{array}$ & 0 & $\mathrm{~N} / \mathrm{A}$ & $\mathrm{N} / \mathrm{A}$ & 0 & $\mathrm{~N} / \mathrm{A}$ & $\mathrm{N} / \mathrm{A}$ & 1 & $100.0 \%$ & $25.7 \%$ \\
\hline $\begin{array}{l}\text { Weld rejected } \\
\text { after sixth repair }\end{array}$ & 0 & $\mathrm{~N} / \mathrm{A}$ & $\mathrm{N} / \mathrm{A}$ & 0 & $\mathrm{~N} / \mathrm{A}$ & $\mathrm{N} / \mathrm{A}$ & 0 & $0 \%$ & $25.7 \%$ \\
\hline $\begin{array}{l}\text { Total weld } \\
\text { rejections }\end{array}$ & & 282 & & & 175 & & & 224 & \\
\hline Total weld & & 937 & & & 800 & & & 871 & \\
\hline $\begin{array}{l}\text { Overall weld } \\
\text { rejection rate }\end{array}$ & & $30.1 \%$ & & & $22.0 \%$ & & & $25.7 \%$ & \\
\hline
\end{tabular}


RPP-RPT-54819, Rev. 0

Table 5-3. 241-AY Tank Farm Primary Tank Bottom Weld Comparison

\begin{tabular}{|l|c|c|c|c|c|c|}
\hline & \multicolumn{3}{|c|}{ Tank AY-101 } & \multicolumn{3}{c|}{ Tank AY-102 } \\
\cline { 2 - 8 } & $\begin{array}{c}\text { Feet of } \\
\text { Weld (ft) }\end{array}$ & $\begin{array}{c}\text { Reject } \\
\text { Rate (\%) } \\
\text { per Repair } \\
\text { Cycle }\end{array}$ & $\begin{array}{c}\text { Total } \\
\text { Reject } \\
\text { Rate (\%) }\end{array}$ & $\begin{array}{c}\text { Feet of } \\
\text { Weld (ft) }\end{array}$ & $\begin{array}{c}\text { Reject } \\
\text { Rate (\%) } \\
\text { per Repair } \\
\text { Cycle }\end{array}$ & $\begin{array}{c}\text { Total } \\
\text { Reject } \\
\text { Rate (\%) }\end{array}$ \\
\hline Weld prior inspection & 672 & N/A & N/A & 673 & N/A & N/A \\
\hline Weld rejected after original weld & 67 & $10.0 \%$ & $10.0 \%$ & 229 & $34.0 \%$ & $34.0 \%$ \\
\hline Weld rejected after first repair & 7 & $10.4 \%$ & $10.0 \%$ & 86 & $37.6 \%$ & $34.9 \%$ \\
\hline Weld rejected after second repair & 1 & $14.3 \%$ & $10.1 \%$ & 27 & $31.4 \%$ & $34.6 \%$ \\
\hline Weld rejected after third repair & 1 & $100.0 \%$ & $10.2 \%$ & 1 & $3.7 \%$ & $33.8 \%$ \\
\hline Weld rejected after fourth repair & 0 & N/A & N/A & 0 & N/A & N/A \\
\hline Total weld rejections & & $\mathbf{7 6}$ & & & $\mathbf{3 4 3}$ & $\mathbf{1 0 1 6}$ \\
\hline Total weld & & $\mathbf{7 4 8}$ & & & $33.8 \%$ & \\
\hline Overall weld rejection rate & & $\mathbf{1 0 . 2 \%}$ & & &
\end{tabular}

The overall weld rejection ${ }^{5}$ rates for SY-101, SY-102, and SY-103 were 30.1\%, 21.9\% and $25.7 \%$ respectively. In comparison, tank AY-102 had a similar rejection rate at 33.8\%. The maximum number of times a weld section was repaired during 241-AY tank farm construction was four, with one weld section in tank AY-101 and one weld section in tank AY-102. During 241-SY tank farm construction, one weld section in tank SY-103 was repaired six times. (Weld rejections were a noted issue in RPP-RPT-53793.) Weld rejection in the 241-SY tank farm is an issue that likely contributed to the bulging seen in the primary tanks and secondary liners of the 241-SY tank farm. It was noted in NCR B-101-34-2307-19 (see Appendix C, App Figure C-2 ) that re-working welds created added distortions. It is likely that weld rejection and repair was a contributor to tank bottom bulging discussed later in Section 5.2. All welds were examined and accepted using the methods described hereafter, and all welds were stress relieved during the post-weld stress relieving process.

Welds were rejected or accepted based on non-destructive examination (NDE) methods. All NDE was performed by American Society for Nondestructive Testing (ASNT ${ }^{6}$ ) SNT-TC-1A certified level II NDE personnel. The level of NDE varied between the primary tank and secondary liner as well as with elevation of the tank. The change in NDE due to elevation was based on the planned use of the tank to contain waste up to a specific elevation. Table 5-4, "241SY Tank Farm Non-Destructive Examinations Used During Construction,” provides a summary of the NDE used to ensure the pedigree of the primary tank and secondary liner.

\footnotetext{
${ }^{5}$ Surface defects on the plate steel accounted for 8 to $10 \%$ of the weld rejection (see Appendix C, App Figure C-1)

${ }^{6}$ ASNT is a registered trademark of American Society for Nondestructive Testing
} 
All welding was performed in accordance with Hanford Standard Specification HPS-220-W with approved procedures qualified in accordance with Section IX, ASME Code, by welders certified in accordance with Hanford Standard Specification HPS-210-W. On 7/31/1974 in the QA log it was noted that an unapproved weld procedure was used to begin welding on the tank SY-102 secondary liner. The weld procedure was later approved and all welds were inspected and accepted using the same methods and procedures.

Table 5-4. 241-SY Tank Farm Non-Destructive Examinations Used During Construction ${ }^{7}$

\begin{tabular}{|c|c|c|}
\hline & Primary Tank Inspections & Secondary Liner Inspections \\
\hline Tank Bottom & $\begin{array}{ll}\text { - } & 100 \% \text { radiography } \\
\text { - } & \text { Magnetic particle } \\
\text { - } & \text { Liquid penetrant } \\
\text { - } & 100 \% \text { visual } \\
\text { - } & \text { Hydrostatic leak test }\end{array}$ & $\begin{array}{l}\text { - } 100 \% \text { radiography } \\
\text { - } \quad \text { Liquid penetrant } \\
\text { - } 100 \% \text { visual }\end{array}$ \\
\hline Bottom Knuckle & $\begin{array}{l}\text { - } 100 \% \text { radiography } \\
\text { - } \text { Magnetic particle } \\
\text { - } \quad \text { Liquid penetrant } \\
\text { - } 100 \% \text { visual } \\
\text { Hydrostatic leak test }\end{array}$ & $\begin{array}{l}\text { - } 100 \% \text { radiography } \\
\text { - } \quad \text { Liquid penetrant } \\
\text { - } 100 \% \text { visual }\end{array}$ \\
\hline Vertical Wall & $\begin{array}{l}\text { 100\% radiography up to } 422 \\
\text { inches, not including the } \\
\text { horizontal weld at } 422 \text { inches. } \\
\text { (See Note } 6 \text { on Primary Shell } \\
\text { Weld Maps in Appendix B) } \\
\text { - } \text { Magnetic particle } \\
\text { - } 100 \% \text { visual } \\
\text { - Hydrostatic leak test }\end{array}$ & $\begin{array}{l}\text { - } 100 \% \text { radiography up to } 324 \\
\text { inches above floor plates. } \\
\text { - } 100 \% \text { visual }\end{array}$ \\
\hline $\begin{array}{l}\text { Upper Knuckle } \\
\text { and Tank Dome }\end{array}$ & $\begin{array}{l}\text { - } 100 \% \text { visual } \\
\text { Hydrostatic leak test of upper } \\
\text { knuckle and the horizontal } \\
\text { weld connecting the dome and } \\
\text { upper knuckle }\end{array}$ & - $100 \%$ visual \\
\hline
\end{tabular}

The radiography inspection on the primary tank and secondary liner bottoms was completed prior to lowering the bottom. Liquid penetrant examination was completed before and after lowering the bottoms.

An example of a primary bottom weld map is shown in Figure 5-1. Each red mark on a weld section represents a weld that was repaired at least once. The circles next to the repaired weld section have values in them such as R1, R2, etc. which represents the number of times a

\footnotetext{
${ }^{7}$ Tank NDE inspection reference documents: B-101-C1, H-2-37772, and Weld Maps (see Appendix B)
} 
particular weld section was repaired. The circle around the weld repair value indicates that the weld was accepted. Welds were inspected in $1 \mathrm{ft}$. long sections; each inspected section is represented with a hash mark in the weld maps. Rejected welds were ground out, re-welded, and re-inspected. The weld maps for all 241-SY tank farm primary and secondary bottoms and side walls can be seen in Appendix B.

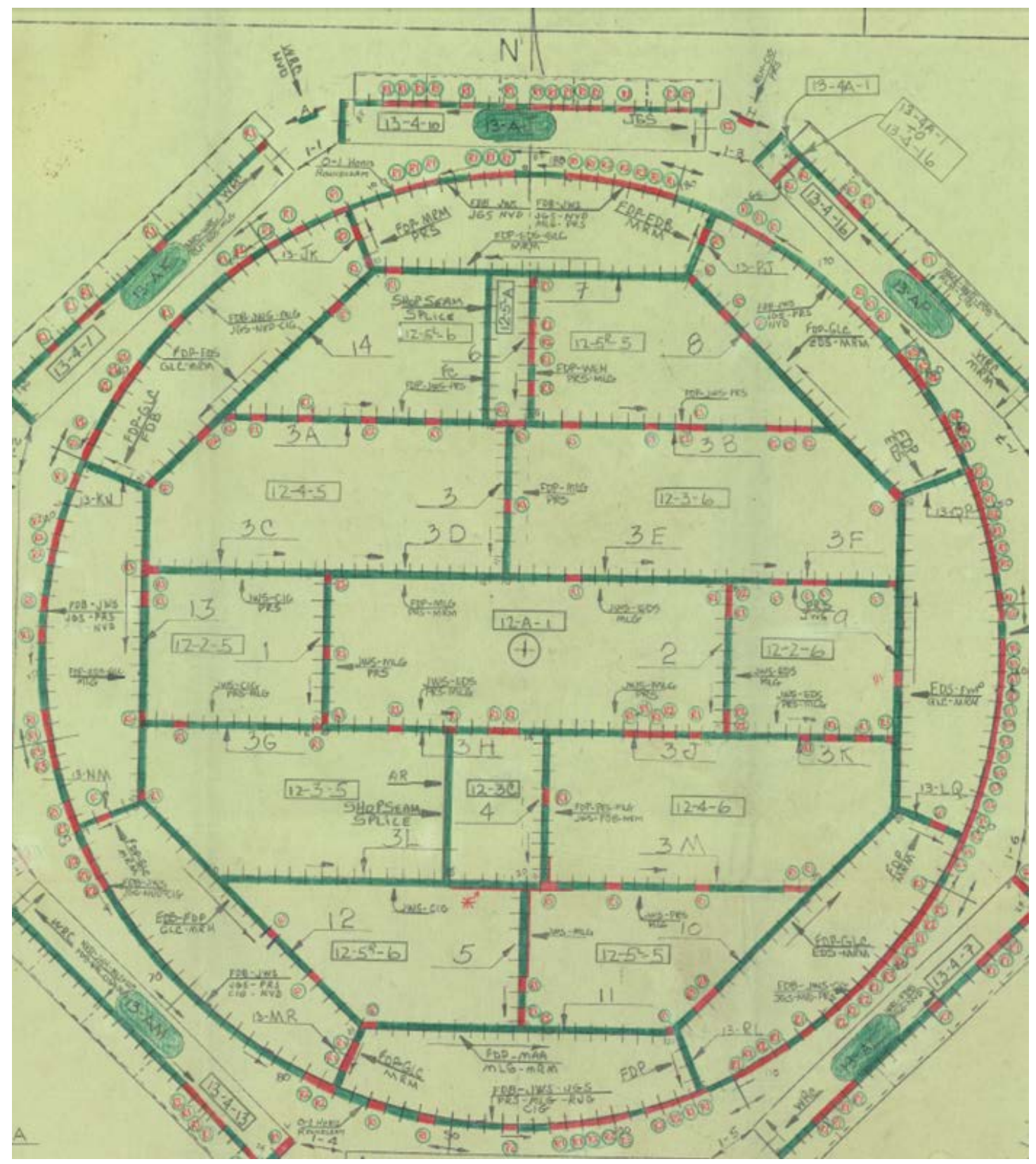

Figure 5-1. Tank SY-101 Primary Weld Map 
RPP-RPT-54819, Rev. 0

\subsection{TANK BOTTOM FLATNESS}

Specification B-101-C1 specified that primary tank bottoms and secondary liner bottoms could have no root to crown slopes ${ }^{8}$ (bulges) greater than $3 / 8$ in. per $\mathrm{ft}$. and a maximum root to crown height measuring 3 in. or less. Specification B-101-C1 also stated the following:

"Where flatness tolerances are not met, correction shall be by the use of 'flanging' torches, or impact tools used only with anvils or 'flatters' so that the force of the impact is distributed. All flattening operations are to be completed prior to stress relieving."

Issues with tank bottom flatness for each tank are discussed in the following sections.

\subsubsection{Secondary Liner Bottom Flatness}

\subsubsection{Tank SY-101}

A survey of tank SY-101 secondary bottom liner found localized out-of- tolerance bulges. An attempt to repair the bulging by cutting seams and re-working welds was unsuccessful. After attempted repairs, there were nine out-of-tolerance bulges in the secondary bottom, the worst measuring 13/16 in. per ft. at its peak. Bulges were later accepted using the suggested disposition in NCR-B-101-22-2307-8 (Appendix C, App Figure C-3) which stated:

"Conditionally accept provided that:

1. The subsequent liquid penetrant examination required after lowering is acceptable.

2. With load of primary tank bottom on refractory and before primary bottom is lowered, inspect and repair refractory cracks and depressions that are greater than the tolerances specified on the drawings and in the construction specifications.

\section{Justification:}

The areas of out of tolerance are localized. Thus, the distribution of loadings will not affect the tank function and integrity."

A method used to measure bulges in the 241-SY tank farm tanks can be seen in Figure 5-2. An inspector is using a level and a measuring tape to measure the root to crown height of a secondary liner bottom bulge during the refractory pour.

\footnotetext{
${ }^{8}$ May also be referred to as distortions, and peak to valley slopes.
} 


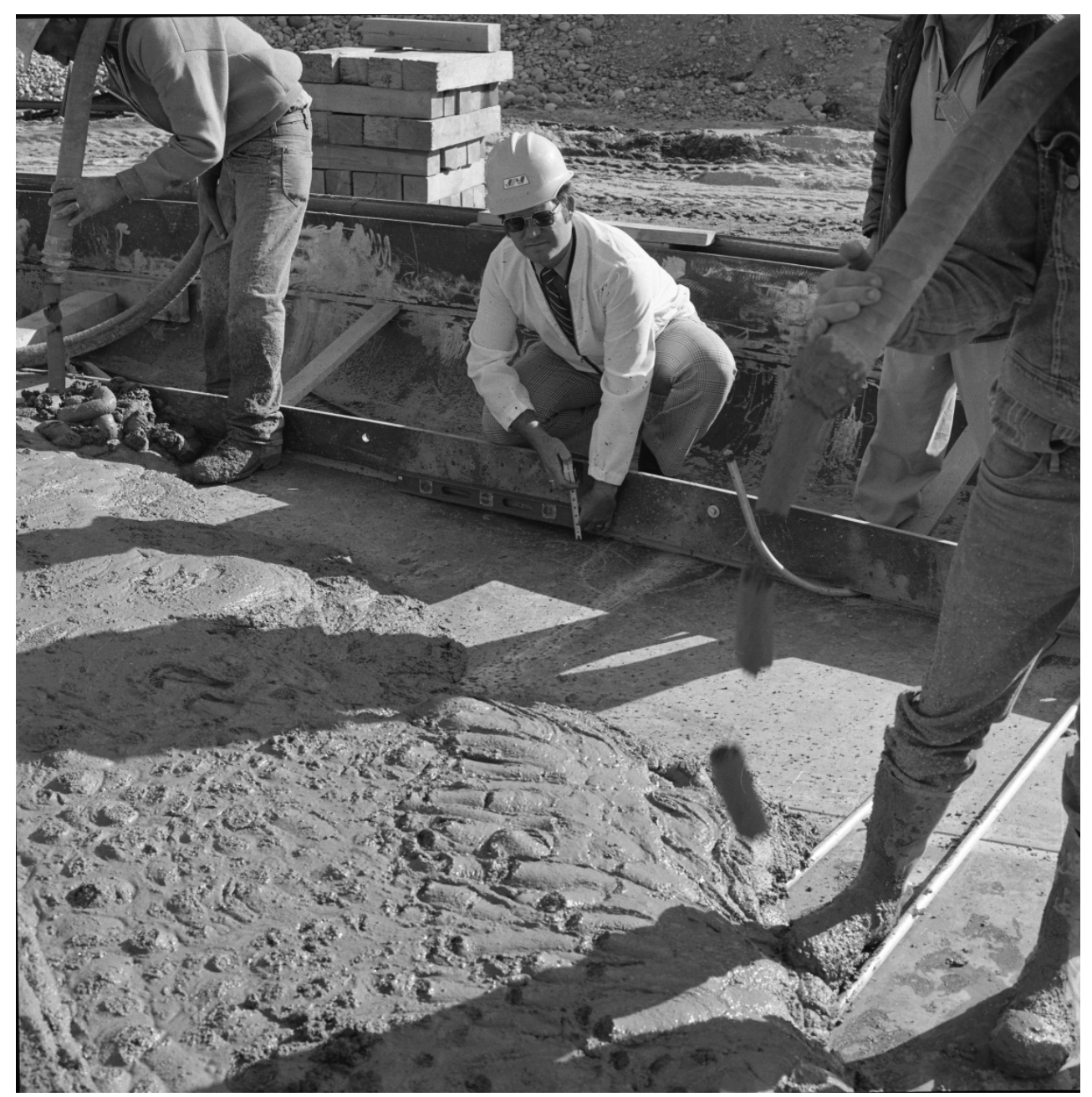

Figure 5-2. Secondary Liner Bulges During Pouring of the SY-101 Refractory (Photo 64906-8) (Taken 10-4-74)

\subsubsection{Tank SY-102}

At least two out-of-tolerance bulges were found in the tank SY-102 secondary liner bottom as noted in NCR-B-101-20-2307-6 (Appendix C, App Figure C-4), with the worst bulge being 5/8 in. per ft. The suggested disposition and justification of acceptance is identical to tank SY-101, NCR B-101-22-2307-8 above. Tank SY-102 also had two bulges within the tangent point of the knuckle curvature (NCR-B-101-21-2307-7, Appendix C, App Figure C-5). 
The disposition and justification was the following:

"Conditionally accept provided that:

1. The subsequent liquid penetrant examination required after lowering is acceptable.

2. With load of primary tank bottom on refractory and before primary bottom is lowered, inspect and repair refractory cracks and depressions that are greater than the tolerances specified on the drawings and in the construction specifications.

Justification:

The areas of out of tolerance are localized. Thus, the distribution of loadings will not affect the tank function and integrity."

No slope was given for the two bulges. Figure 5-3 is a sketch of one of the bulges noted in NCR B-101-21-2307-7 (see Appendix C, App Figure C-5). Assuming the measurements are taken from the upper tangent point, the distance to the theoretical tank bottom is $12 \mathrm{in}$.

TO ..LR B-101-21-2307-7

DISTORTION AREA "A"-PROFILE

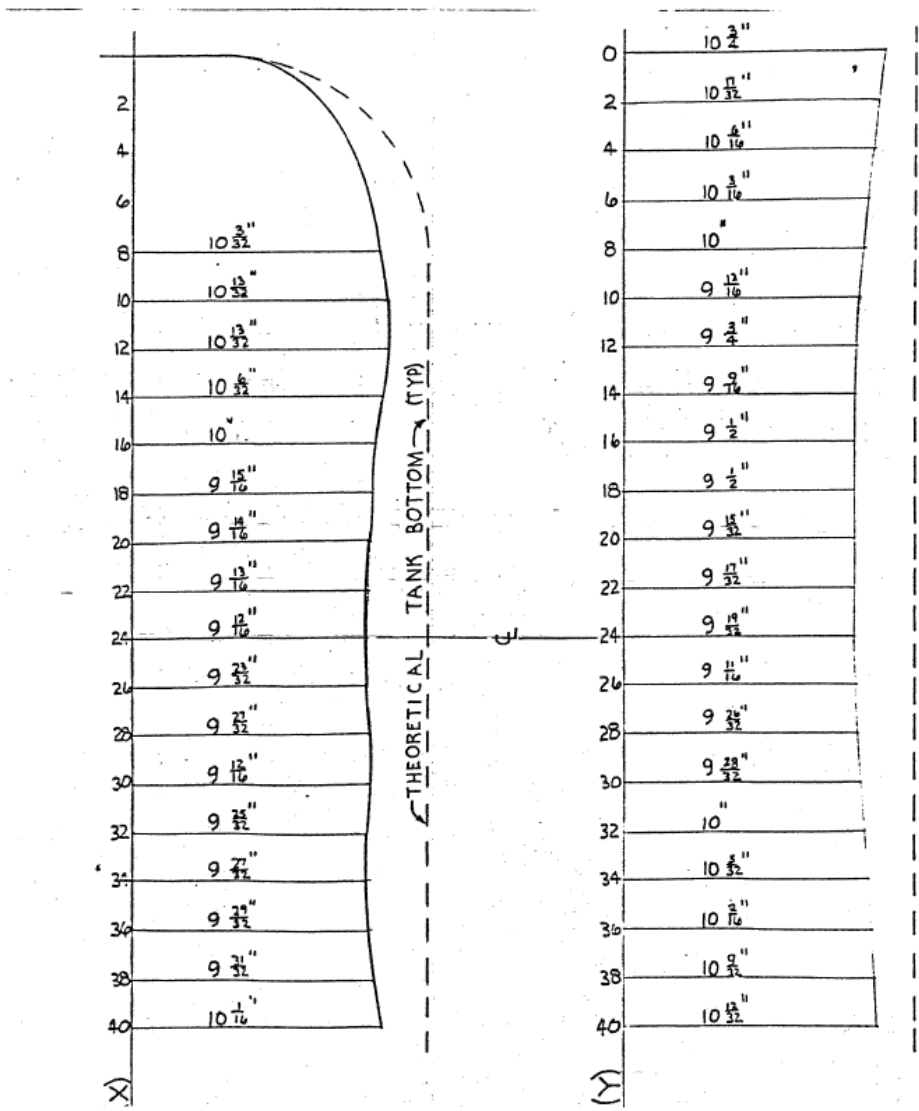

Figure 5-3. Tank SY-102 Sketch of Bulging Within the Tangent Line to the Knuckle 


\subsubsection{Tank SY-103}

The welding sequence was revised prior to the secondary bottom fabrication of tank SY-103 in an attempt to correct the tolerance problem seen in the secondary liner fabrication of tanks SY101 and SY-102. The effort was unsuccessful as bulges of up to $1 \mathrm{in}$. per ft. were noted in NCRB-101-24-2307-9 (see Appendix C, App Figure C-6). An attempt was made to reduce the slope of the two bulges.

On 12/18/1974, it is noted in the QA log:

"103 Secondary - CB\&I is trying to reduce the slope at 2 locations on the tank bottom. Air hammers against planishing (sic) hammers were used to see if the slope could be hammered down. I saw no change in the condition. Next, $6000 \mathrm{lbs}$ was placed on the hump \& again air hammers were used. Again no change was noted."

The next day on 12/19/2013, the QA log states:

"103 Secondary Tank Bottom: A magnetic particle test was requested on the area that had been jack hammered upon yesterday (high-low area). At 2:00 PM I witnessed that test and found no questionable areas on either the weld pass or plate material itself."

The suggested disposition in NCR B-101-24-2307-9 for tank SY-103 secondary liner bottom bulges was:

"Conditionally accept provided that:

1. The subsequent liquid penetrant examination required after lowering is acceptable.

2. With load of primary tank bottom on refractory and before primary bottom is lowered, inspected and repair refractory cracks and depressions that are greater than the tolerances specified on the drawings and in the constriction specifications.

\section{Justification:}

The areas out of tolerance are localized. The distortion at location ' 2 ' was rechecked and it

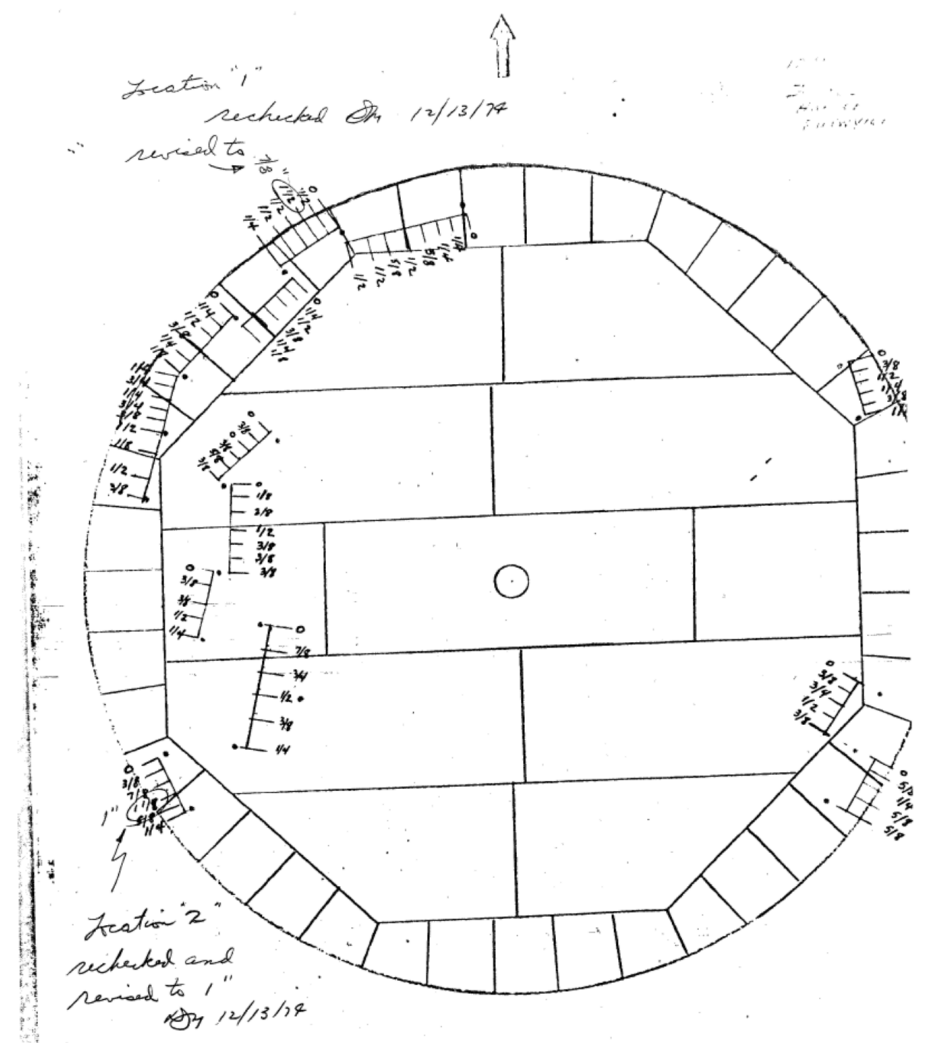

Figure 5-4. Attachment to NCR B-101-24-2307-9 Showing Location 1 and Location 2 
RPP-RPT-54819, Rev. 0

was noted that the high point lies in the center of that plate material. Since the peak does not occur in the weld area, this distortion and the other distortions will not affect the tank function and integrity."

The weld sequence was again significantly modified. An elaborate system of strongbacks was utilized for future tank bottom welding. The new weld sequence and strongbacks were first implemented on the primary tank bottom in SY-102, discussed later. Location 2 in the above quote can be seen in Figure 5-4. The primary cause listed in the NCR's for the secondary liner bulges in each tank was "unsatisfactory weld sequence."

\subsubsection{Primary Tank Bottom Flatness}

After the out-of-tolerance problem in the tank SY-103 secondary liner bottom, the weld sequence was significantly modified for a second time. A system of strongbacks was added in an effort to meet the root to crown slope specifications. The new weld sequence was used on all of the primary tank bottoms.

\subsubsection{Tank SY-101}

Primary tank SY-101 was initially accepted and declared to be within bottom flatness tolerances. In Vitro-R-389, Strain Gage Activity (July 31 thru August 25, 1975) Relating to Primary Tank 241-SY-103, the following observations were made:

5. "...The bottom was fabricated and was out of tolerance. One area that was out of tolerance was determined to be a ridge distortion caused by the weld could be fixed (sic) by removing and rewelding three seams. This was done and that particular location came within tolerance, however new areas developed which were marginal as to being within tolerance. The bottom was then lowered and the out of tolerance areas redistributed leaving a bottom within tolerance."

An ARHCO review of Vitro Engineering inspection reports found no documentation of a primary tank SY-101 bottom survey after lowering. It is unclear what generated the concern over bottom flatness in primary tank SY-101 after initial acceptance, but it is assumed that the lack of documentation led to an inspection of the primary tank SY-101 bottom. Primary tank SY-101 bottom flatness was questioned in an October 1, 1975 letter to J.F. Albaugh, Documentation of Verification of SY Tank Farm Tank Bottom Flatness (see Appendix C, App Figure C-7). A follow-up inspection of primary tank SY-101 bottom revealed at least two bulges near the lower knuckle.

It was suggested in a May 4, 1976 letter to V.D. Schrag, Bottom Flatness Survey Tank 101-SY (see Appendix C, App Figure C-8), that loading imposed on the knuckle during construction caused the bulge found in the primary tank SY-101 bottom after initial acceptance.

In a letter from Battelle Pacific Northwest Laboratories to J.F. Albaugh (ARHCO) on August 19, 1976 (Appendix C, App Figure C-9), it is noted that the work performed in BNWL-B-475, Computer-Based Structural Investigation of the SY-103 Waste Storage Tank Which Contains 
Out-Of-Tolerance Bottom Bump, and in ARH-R-172, Analysis of Underground Waste Storage Tanks 241-SY at Hanford, Washington, has "provided us with much insight into the tank fabrication problem and forms the basis for our present attitude on the SY-101 tank bottom question." It is also noted in the letter that any effort to analyze the actual "bump" would not be cost effective and:

“...it is very likely to result in a conclusion that using the bumpy bottom without fixing the bumps would be unacceptably risky due to imposed, high flexural stresses during filling. Hence some stabilizing technique, like bump grouting, would be indicated to support the flexing.

We find no difficulties associated with mechanics problems which might be imagined as a result of grouting, provided, the grout compliance and thermal properties are reasonably like that insulating concrete found under the remainder of the tank bottom (recalling that the insulating concrete has experienced thermal effects from the stress relief treatment)..."

The analysis conducted on primary tank SY-103 (see Section 5.2.2.3) was used as the basis for determining the acceptability of the primary tank SY-101 bottom.

The solution to the bulge is found in Record of Design / Field Change B-101-128, which states the following:

"Description

0 Grout out-of-tolerance bumps in the primary tank bottom of the 241-SY-101 tank. Location approximately at $0^{\circ}$ and $180^{\circ}$ of the tank as shown on ES-B101-MG.

o Grouting procedure per JA Jones submittal dated 7/1/76.

o Structural stress supporting rationale per Vitro inputs attached.

\section{$\underline{\text { Justification }}$}

To provide support to out-of-tolerance tank bottom to eliminate high stress potential."

The decision was made to grout the bump areas beneath primary tank SY-101. A construction verification checklist which verifies the completion of the grouting at both $0^{\circ}$ and $180^{\circ}$ relative to north is found in App Figure C-10 in Appendix C. 
A procedure for completing the design change is attached in Appendix C, App Figure C-9 which lists the following steps.

"This procedure is to outline the method used to grout under the primary tank bottom of Tank 101 in 241-SY Tank Farm. The reason for grouting is to give full support of the primary bottom in the area defined by drawing ES-B-101-M6 (sic).

(1) Assemble material and equipment.

(2) Check material as being light weight -50 or 70 .

(3) Layout areas to be grouted on the outside primary tank.

(4) Cut out retainer band 2 to 3-feet long and remove. Cutout is to be centered on major axis of deformation.

(5) Chip out existing refractory a minimum 2-feet wide 8-inches deep and 8-feet long. Remove broken refractory and vacuum all dust and particles from work area.

(6) Fabricate slot forms using sheet metal and install.

(7) Mix refractory per manufacture's recommendations and hand pack between existing refractory and tank bottom.

(8) Re-weld retainer band in place after minimum of 48 hours cure on refractory.

(9) Re-clean entire area and inspect."

The construction verification checklist verifies that a section of steel retaining band was removed, refractory was chipped out, metal forms were installed for air distribution slots, grout was placed, the retainer band was re-welded, the area was cleaned and inspected, and no damage to the primary tank occurred during the repair. The grout used to backfill under tank had a compressive strength of 3,100 psi, which is considerably higher than the 130 psi required for the refractory. If any of the sheet metal slot forms are in contact with the tank bottom, it creates the potential for localized corrosion. A diagram of one of the two bulges in primary tank SY-101 can be seen in Appendix C, App Figure C-11.

\subsubsection{Tank SY-102}

Primary tank SY-102 bottom was the first primary tank bottom to implement the new welding sequence with added strong backs in an attempt to maintain bottom flatness tolerances. In VitroR-389, Appendix A, it is stated that “...On completion of fabrication this primary bottom was out of tolerance, however after lowering the areas out of tolerance shifted and reduced so that tolerances were achieved." Tank SY-102 primary bottom was found to fall within root to crown tolerances once the tank was lowered onto the refractory, which led to the acceptance of primary tank SY-102 bottom flatness.

\subsubsection{Tank SY-103}

The primary bottom of tank SY-103 did not achieve tolerance when the new weld procedure was used, and it was determined that re-welding would not guarantee a successful repair. The primary bottom of tank SY-103 was found to have nine bulges, the largest being a bulge with a slope of 13/16 in. per ft. which resulted in NCR B-101-34-2307-19 (see Appendix C, App Figure C-2). 
RPP-RPT-54819, Rev. 0

The suggested disposition and justification in NCR B-101-34-2307-19 is as follows:

"Suggested Disposition:

'Conditional accept' provided that the subsequent liquid penetrant examination required after lowering is acceptable.

\section{Justification:}

The areas out of tolerance are localized. Thus, the distribution of loadings will not affect the tank function and integrity."

The letter attached to the NCR states, "The results of any repairs that could be made to correct the deficient areas are questionable as to their success for the following reasons:

1. Deficient areas move as a result of lowering the tank bottoms and if the bottom is raised to affect a repair the same area may not be out of tolerance when raised.

2. Past experience on tanks 102 and 101 indicated that reworking seams creates added distortion elsewhere in the tank bottom which could result in a worse new condition than presently exists.

3. Since the discrepancies in the 103 primary bottom are not limited to the seam areas themselves, additional seams would be required to be added to the bottom plates.

Since engineering design has examined the areas and determined that existing discrepancies will not affect the tank function or integrity and because of the inability to guarantee a successful repair, we feel that a repair cannot be justified.”

In September 1975, Vitro Engineering conducted an engineering study that was later compiled into interim report Vitro-R-350, Tank Bottom Flatness Engineering Study. The engineering study considered relaxing the $3 / 8$ in. per ft. root to crown slope specification by investigating the basis for the tolerance, and by analytically testing the tolerance using a computer model. The initial results from the analytical ANSYS computer model analysis in Vitro-R-350 conclude the following:

"These models arbitrarily considered the hump to transgress the radius region of the knuckle. It is in the knuckle region where elevated stress levels were detected. There were other areas of elevated stress and these regions will be discussed under 'Validity of Results' in section D.5.... It is therefore necessary that future tank criteria maintain strict limitations on the slope and size of humps formed in the one-million-gallon tanks, and that these humps shall not be permitted to be located in close proximity to the knuckle region." 
RPP-RPT-54819, Rev. 0

Although high stresses were found in the ANSYS tank bottom model, there were questions whether or not it represented the actual tank bottom and loading accurately, as described in Vitro-R-350 below:

\section{5. "Validity of Results:}

The ANSYS tank bottom models do not portray any existing nonconformance in any tank. The geometry attempted to match a possible discrepancy permitted by the existing construction specification (Version 2.1). Granted the boundary conditions of the model may have produced higher stress values than actuality, the results are believable when you compare these stresses to an axisymmetric model results (sic)... The bottom shell elements of the tank bottom model show elevated bending stresses, which may not be true in all cases because of the manner by which they were loaded... But because high stresses were found in the knuckle region where this loading condition is different, the effort and expense to nullify the artificial bending stress in the bottom shell elements were not made."

Construction was halted on tank SY103 to allow an in-depth review of the primary tank bottom. Halting construction allowed the annulus to remain open, providing easier access to the primary tank if it was needed.

Along with the ANSYS computer analysis described in Vitro-R-350, it was suggested that strain gauges be attached to primary tank SY-103 prior to filling the tank with water for hydrostatic testing. The data gathered from strain gauges during hydrostatic testing would be used to compare and verify the ANSYS analysis. A report of the strain gauge activity and data was recorded in Vitro-R-389, the source document covering all strain gauge activity and data pertaining to primary tank SY-103. The ANSYS

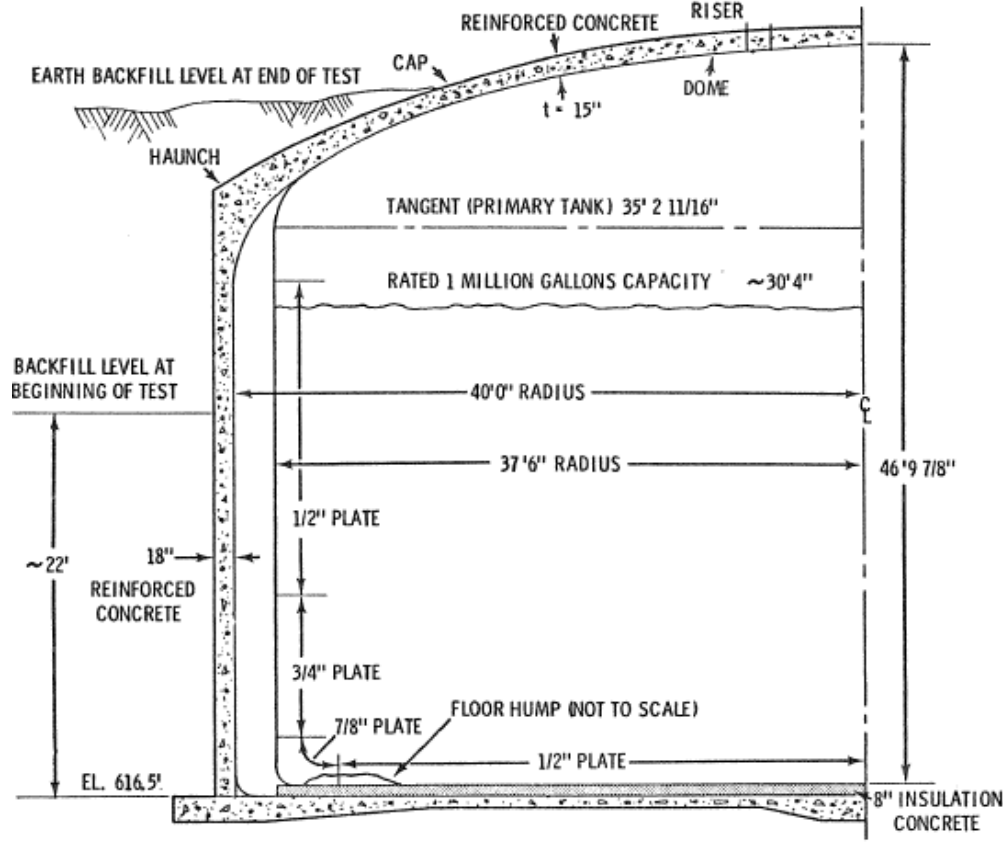

Figure 5-5. Cross-Sectional Illustration of Tank SY-103 Waste Tank

computer analysis and strain gauge testing were done concurrently, and reports Vitro-R-350 and Vitro-R-389 were both released in September, 1975. A diagram of the bulge in primary tank SY-103 can be seen in Figure 5-5.

Vitro Engineering began the initial strain gauge testing by installing eleven strain gauges in the bulge region of primary tank SY-103 bottom. A baseline strain gauge reading was taken with no water present in the tank. Strain gauge readings were also taken at water levels of $15 \mathrm{ft} .-3 \mathrm{in}$., and $39 \mathrm{ft}$. 
From Vitro-R-389, initial strain gauge data analysis on August $13,1975^{9}$ reported the following:

“August 13, 1975: Preliminary analysis of strain gage (sic) data by Akerson, Fick, and Hecht indicated that stresses in excess of the yield strength of the material had occurred..."

The preliminary results appeared to support the idea that tensile stresses in the bulge area were greater than the yield strength of the steel during hydrostatic testing.

The results also prompted another attempt to take strain gauge readings at a water level of $39 \mathrm{ft}$. on August 14, 1975. The results of the attempt are as follows:

“August 14, 1975: Because of the unexpectedly high strain indications, additional strain gage (sic) readings were taken by Akerson, Stratton, and Basile with water level in the tank at $39 \mathrm{ft}$...Additional readings were taken with the compensating gage and measuring gage terminal reversed...In addition, readings were taken with several gages connected in a three-wire configuration... and while the readings were different from those obtained using the two-wire method, the differences were so insignificant that this procedure was discontinued and readings were not recorded."

After the second attempt to gather strain gauge data from tank SY-103, a decision was made to begin an overall non-destructive testing program on the primary tank. The Exxon Nuclear Company (Exxon) was asked to propose an acoustic monitoring program to be conducted during a water filling operation. The proposal was reviewed and accepted. A description of the technology, testing procedures and results can be found in XN-331, Technical Report for NDT Acoustics Testing of the Primary Shell of Atlantic Richfield Hanford Company Tank 103.

The analysis from XN-331 states the following:

\section{"Data Analysis Results}

Acoustic data were acquired as per XN-276.01 commencing at the 1.25 foot level and continued throughout the fill of tank 103.

A total of 45 computer runs were conducted during and after the fill of storage tank 103. No 'significant' defects (grade 3 defects that would jeopardize the structural integrity of the tank) were found...

...A total of eleven gradable sources were located on the tank. All eleven gradable sources were analyzed as Grade 1. Other detected acoustic sources were of such minor nature that they did not meet minimum grading criteria..."

Battelle Pacific Northwest Laboratories (BNWL) was also contacted to monitor tank SY-103 primary tank utilizing strain gauges during the emptying of the hydro test water and second filling of the tank.

\footnotetext{
${ }^{9}$ The initial strain gauge test has been referenced in several reports including ARH-LD-146 Technical Record of the 241-SY-103 Primary Tank Bottom Flatness Studies and VITRO-R-350 Tank Bottom Flatness Engineering Study. However, the actual test documentation has not been found.
} 
BNWL-B-471, Strain Survey From a Hydrotest of the Primary Waste Tank 241-SY-103, is the follow-on report generated by Battelle Pacific Northwest Laboratory. The results from BNWLB-471 are summarized as follows:

“Tank B-103 (sic) from tank farm 241-SY, having a non-conformance hump on the floor of the primary structure, was instrumented with strain gages (sic) and hydro tested. The highest compressive stress of 29,200 psi occurred on the outside surface of the knuckle region at the beginning of un-watering (water depth 43'-7"), while during subsequent filling at a maximum water level of 51'-9" the same location recorded a compressive stress of 25,400 psi.

In general, stresses in the vicinity of the floor hump were lower than stresses on corresponding locations away from the hump. The reinforced concrete outer structure after curing appeared to reduce all stresses to a lower level."

Figure 5-6 shows strain gauges ready to take strain measurements at the lower knuckle of primary tank SY-103 during a structural integrity study of the primary tank bottom.

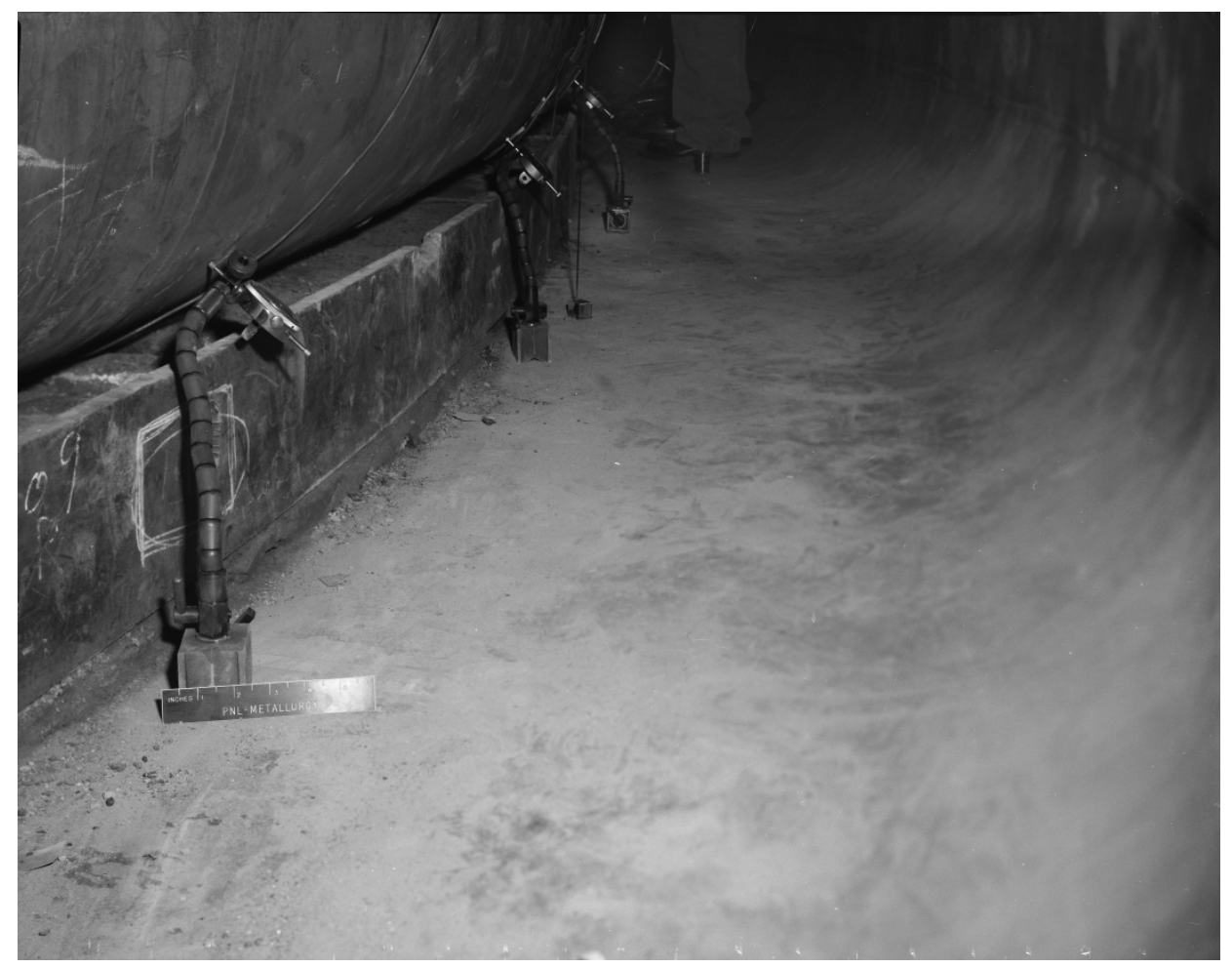

Figure 5-6. Battelle Strain Gauges on Primary Tank SY-103 (Photo 756534-20) (Taken 9-12-1975)

Additionally, after a review of the procedure used by Vitro Engineering during initial strain gauge testing, it was noted in BNWL-B-471 that there was room to doubt the validity of the results for the following reasons, "After consultation with Battelle-Northwest, analysis of the test procedure showed inadequate temperature compensation, long leads effects (two-wire readout) and possible capacitance effects caused by water surrounding the strain gage (sic) leads." These factors were not accounted for during the initial strain gauge monitoring. An independent 
review of the structural study reported in BNWL-B-475 was conducted by an "experienced staff member of the Engineering Technology Department. He has concluded that expected service performance of the SY-103 tank has not been compromised by the slightly out-of-tolerance bump."

Other non-destructive testing was conducted on primary tank SY-103 during and after hydrostatic testing such as, liquid penetrant examination of the inside and outside of primary tank SY-103. Magnetic particle, and visual examinations were conducted on the outside surface of primary tank SY-103. All tests found primary tank SY-103 to be acceptable. The sequence and summary of all the non-destructive tests and the results are compiled into ARH-LD-146, Technical Record of the 241-SY-103 Primary Tank Bottom Flatness Studies.

\subsubsection{1-SY Tank Farm Bottom Flatness Issues Summary}

Tanks SY-101, SY-102, and SY-103 all had out-of-tolerance bulging in the secondary liner bottoms attributed to sequencing of the welding operation. After attempting to correct the outof-tolerance condition, each secondary liner bottom was conditionally accepted using the criteria noted in the respective NCR written for each secondary liner. The bulging in the secondary liners of the 241-SY tank farm is very similar to the bulging noted in tank AY-102 in RPPASMT-53793. The principal issue with unsupported bulges in the secondary liner is that the bulges compress under the weight of a filled primary tank. The refractory may then crack due to its lack of strength in shear, leaving portions of the primary bottom unsupported.

Tanks SY-101 and SY-103 had out-of-tolerance bulging in the primary tank bottom. The refractory in tank SY-101 was chipped out in two locations and backfilled with grout to help support the bulging found in the primary bottom. Once the grouting was completed, tank SY101 was accepted and signed off as construction complete. Extensive analysis, strain gauge, and acoustics testing were conducted on the bulge in tank SY-103. The measured stresses in the tank during hydrostatic testing were initially found to exceed the yield strength of the material. After multiple reviews by consultants and NDE contractors and further testing, the bulges in primary tank SY-103 bottom were conditionally accepted and construction continued. The primary issue with unsupported bulging in the primary tank bottom is the presence of tensile or compressive stresses along the wetted surface. This condition is thought to be a contributor to potential failure by stress corrosion. Primary tank AY-102 flatness is noted as being generally good, with very little mention of bumps or bulging during construction although voids between the primary bottom and refractory were filled with foam during refractory repair, (RPP-ASMT-53793). Table 5-5 lists the tanks that contain bulging, and whether the bulging is located in the secondary liner bottom, primary tank bottom, or both. 
RPP-RPT-54819, Rev. 0

Table 5-5. Bulges by Tank

\section{\begin{tabular}{l|l|l|l} 
Tank & SY-101 & SY-102 & SY-103
\end{tabular}}

\begin{tabular}{|l|c|c|c|}
\hline Secondary & Y & Y & Y \\
\hline Primary & Y & N & Y \\
\hline
\end{tabular}

Y - Denotes tanks with out-of-tolerance

root to crown distortions

$\mathrm{N}$ - Denotes tanks with no out-of-tolerance

root to crown distortions

Overall, 241-SY tank farm bulging issues increased over those documented in RPP-ASMT53793 for tank AY-102. Bulging occurred in all of the secondary liner bottoms as well as two of the primary tanks in the 241-SY tank farm. This creates the potential for higher tensile and/or compressive stresses along the wetted surface of the primary tank. High stresses in the wetted perimeter are thought to be a related cause of stress corrosion cracking. Regarding tank bottom construction in the 241-SY tank farm, those factors that caused unsupported areas and the potential for areas of high residual stress in tank AY-102 are present in all of the 241-SY tank farm tanks.

\subsection{REFRACTORY}

The original refractory specified in the 241-SY tank farm construction specification was to be either Kaolite 2200LI (used in 241-AY tank farm) or Kaolite 2000 (used in 241-AZ tank farm), although the construction specifications allowed alternate material provided that it met the specifications (B-101-C1). The contractor selected a substitute material, LW50, made by PryorGiggey. Mechanical properties' testing was required for the LW50 material and testing initiated by BNWL early in the project.

Minor difficulty in the testing by BNWL was mentioned in the QA log on 6/7/1974. Not enough sample was provided for testing and new mixing instructions were required to produce a pourable mixture.

The first refractory installation was initiated for tank SY-102 on 9/25/1974. The test report for LW50 was issued shortly after on 10/16/1974 as a Battelle letter, Evaluation of Lite Wate 50 Castable Refractory, and can be found as Attachment 9 to RPP-19097, Evaluation of Insulating Concrete in Hanford Double-Shell Tanks. The refractory met the required test specifications for compressive strength, but the testing showed heating too rapidly would destroy the sample. Review comments provided by the ARHCO structural expert on 11/1/1974 (also found in Attachment 9 to RPP-19097) expressed concern about this, the need for temperature control for the initial heat-up to $600^{\circ} \mathrm{F}$, and the possibility that the refractory could be saturated at the start of stress relieving. He also expressed questions about test results that showed a reduction in compressive strength after radiation exposure. Revision and additional testing were suggested to understand the heating rate but there is no record that it was performed. 
Resistance of the refractory to a tank waste simulant was not demonstrated by laboratory testing as was done for 241-AY and 241-AZ tank farms. The manufacturer provided a letter certifying the refractory was compatible with a list of chemicals specified in the construction specification (B-101-C1) that was similar to the simulated tank waste used in earlier testing. The letter is also found in Attachment 9 to RPP-19097 and contains an error. The solution concentrations are given in parts per million (ppm) and not molar $(\underline{\mathrm{M}})$ as specified in the construction specification. No reconciliation of that error could be found.

Weather protection was specified for the refractory. Drawings include the note "Insulating concrete shall be protected from freezing at all times". As mentioned in Section 4.3, a heating grid was installed on top of the refractory for SY-101 and SY-102 to provide protection from freezing temperatures. The grid was covered with sand, insulation and plywood. Just prior to lowering the primary bottoms for these tanks, this system would be removed. The refractory installation for tank SY-103 was postponed until the next spring, after freezing temperatures had passed.

Issues with the refractory for each specific tank are discussed in the following sections.

\subsubsection{Tank SY-101}

There was one refractory-related issue with tank SY-101. On 3/18/1975 the QA log notes that refractory was pumped into tank SY-101 refractory in damaged areas:

"Insulating concrete was pumped into the 101 tank refractory in the two damaged areas which had been chipped out..."

No prior mention of this refractory issue in tank SY-101 prior to QA log entry 3/18/1975 could be found, and no other construction documents have been found regarding damage or repair to this refractory. Without additional documentation, it is not possible to quantify the extent of damage to the refractory. It is known that all cylinder test reports had to be accepted prior to tank operation.

\subsubsection{Tank SY-102}

A QA log entry dated February 7, 1975, (see entry number 89, Appendix A) notes that tank SY102 refractory developed cracks around the cribbing supports. The QA log entry states:

"102 Primary bottom... Insulating concrete has cracked around some of the twelve cribbing supports. In most cases, cracking is minor. Thompson will repair the only really bad area over the weekend."

The refractory was repaired the next day on 2/8/1975. The repair was noted in the QA log:

“...decided to take out an area approx. 8'-0" $\times 5$ '-0" and 2" deep, this is the area that was broken...[The contractor] started sawing...when he completed sawing it, he started breaking it out with a hammer and wood chisel. It was broken out approx. 2 1/2 inches deep. I informed the contractor that they would have to use hot water to mix the aggregate...the concrete was mixed by hand and placed at $65^{\circ} \mathrm{F}$." 
The only weather related issue specifically noted was in the QA log entry on February 10, 1975 (entry number 92 in Appendix A).

"102 Primary Bottom - Slight frost was detected on some areas of the insulating concrete surface (temperature $30^{\circ}$ ). Areas were Hammer tested by E.S. Davis, and seemed ok. Lowering of primary bottom was commenced at 2:00 PM..."

Little mention was found of refractory behavior during the heating from the post-weld stress relieving process. The QA log noted that during the $600^{\circ} \mathrm{F}$ hold, (intended to bake-out the refractory to remove any water and form a ceramic material), that some steaming may have been observed. On 6/22/1975 it was noted that,

"At 3:30 pm, contractor is still in the process of baking out steam from the insulating concrete."

This time was 22.5 hours from the start of the stress relieving process and by 10:42 a.m. on 6/23/1975 (just over 19 hours later) the lowest temperature recorded on the primary was above $1100{ }^{\circ} \mathrm{F}$. By comparison, in tank AY-102, over two days of heating were required to remove the water from the refractory and increase the tank bottom to a temperature over $210^{\circ} \mathrm{F}$, with escaping steam evidenced for an extended period. An additional two days of heating in AY-102 was required to approach temperatures required for stress relieving. Excessive rain water in the refractory was attributed to long delay in the stress-relieving process and the resulting badly damaged refractory seen in both 241-AY tanks.

Later in construction, after the post-weld stress relieving, the tank SY-102 refractory was inspected and only minor damage was reported. In Figure 5-7 is a diagram from a report titled, Report on Field Investigation of the Tank 102-SY Insulating Concrete Around Tank Perimeter After Primary Tank Stress Relief, dated 7/25/1975, which was ten days after the hydrostatic testing was completed on this tank. A copy of the report is in Appendix C as App Figure C-12. The report refers to three perimeter areas where degraded refractory was noted. None were noted as penetrating past the knuckle tangent point. One indicated friable layers between 1/8 in. and 1 1/4 in thick over an area 8 in. by 6 in. Another area noted was a crack 1/8 in. wide. The third area was a friable layer $1 / 2$ in. thick by $2 \mathrm{ft}$. wide approaching the knuckle area. It was also noted that approximately 50\% of the perimeter had friable material between 1/8 in. and 3/16 in. thick. Apparently no repair was made to the friable material, and the refractory was left as is. 


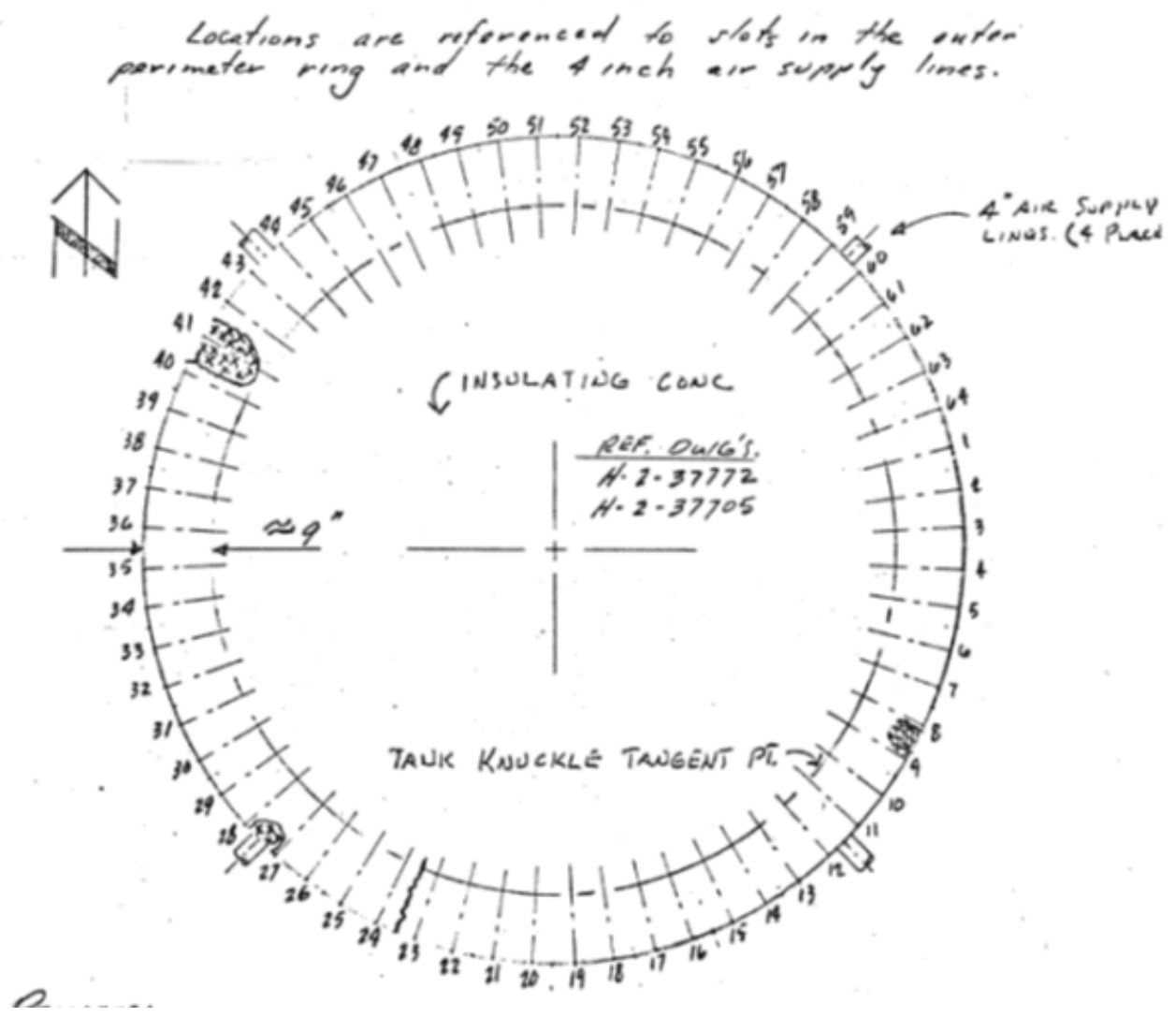

Figure 5-7. Diagram from Report on Field Investigation of the Tank 102-SY Insulating Concrete Around Tank Perimeter After Primary Tank Stress Relieving

This was the first tank constructed in 241-SY tank farm and the only one where a specific refractory inspection report was found after stress-relief and hydrostatic test. The damage was minor. No mention or record of refractory repair to the minor damage seen in tank SY-102 was located. It is assumed the minor damage was accepted as is. No record of similar posthydrostatic test refractory inspection was found for the other 241-SY tank farm tanks.

\subsubsection{Tank SY-103}

No specific deficiencies were found in the logbooks for tank SY-103. An NCR was located documenting that the refractory was not level and did not meet the $\pm 1 / 4$ inch specification (NCR B-101-32-2307-17). A survey of the insulating slab identified it was as much as 0.95 inches below and 0.82 inches above the specified base elevation. The cause was attributed to the limited access making form resetting difficult. The corrective action was to install the refractory before primary tank fabrication to avoid the access issues. The justification to accept the nonconforming condition" as-is” was that the refractory thickness was still adequate and the tank design and function were not affected. A copy of the NCR is included in Appendix C, App Figure C-13. 


\subsubsection{1- SY Tank Farm Refractory Issues Summary}

Issues noted in this report pertaining to the 241-SY tank farm refractory were relatively minor. The refractory used met compressive strength specifications when tested, but it was apparently never tested for exposure to simulated caustic tank waste solutions. Weather/freeze protection was specifically requested during construction and provided by the use of a heating grid system or cold weather prohibition. Minor freeze damage was noted on tank SY-102. Repairs were minor when compared to the extensive refractory repairs to tank AY-102 described in RPPASMT-53793. Minor steaming was mentioned during the stress relieving step on the tank SY102. Overall, the refractory construction in 241-SY tank farm was improved over the refractory construction in the 241-AY tank farm.

\subsection{ISSUES UNIQUE TO 241-SY TANK FARM}

\subsubsection{Deformation of Tank SY-102 Secondary Liner}

During the lowering process of the tank SY-102 secondary bottom, eight hydraulic jacks were set up around the perimeter of the tank bottom as seen in Figure 5-8. Four hydraulic jacks were operated off each of two manifolds, using one operator per manifold. A lack of hydraulic jack control led to distortions of up to $18 \mathrm{in}$. when four of the jacks were lowered 8 in. relative to the other four jacks. NCR B-101-19-2307-5 was generated and can be found along with the attachments depicting the tank bottom distortion in Appendix C, App Figure C-14.

The suggested disposition and justification from the NCR are as follows:

"Conditional accept provided that:

1. The subsequent liquid penetrant examination required after lowering is acceptable.

2. There are no unacceptable permanent distortions.

3. With load of primary tank bottom on refractory and before primary bottom is lowered, inspect and repair refractory cracks and depressions that are greater than the tolerances specified on the drawings and in the construction specifications." 


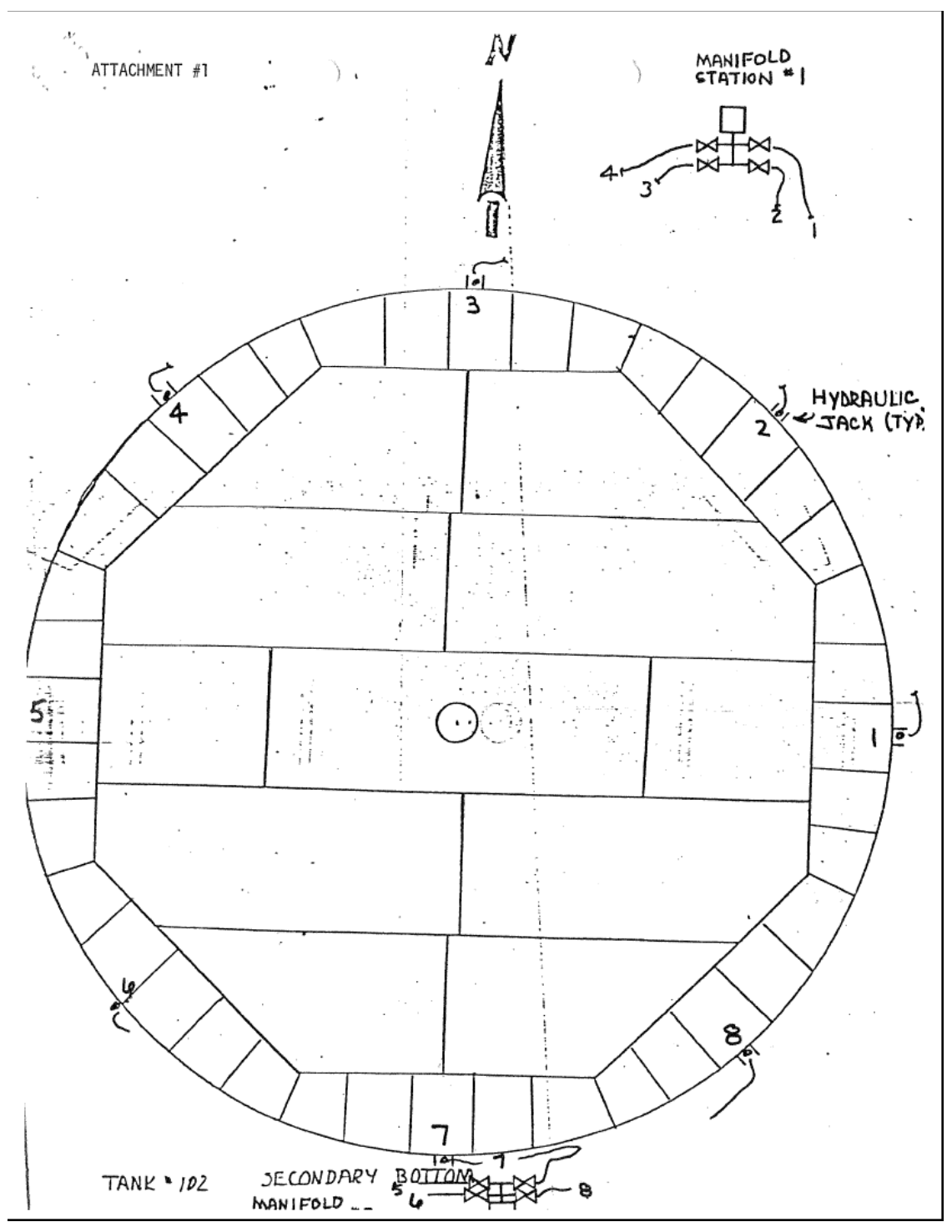

Figure 5-8. Tank Bottom Jack Location

The lowering procedure was noted as the cause for the non-conformance. The procedure was changed to minimize any future issues.

\subsubsection{Weld Splice Joint}

Steel plates to be used in the 241-SY tank farm were required to go through a receiving inspection to determine if they conformed to the desired specifications. Two primary bottom plates were measured for thickness and found to be out-of-tolerance. One of these plates was used in primary tank SY-101. To correct the issue, the end of the steel plate which did not meet thickness tolerances was cut off and a new plate spliced (welded) on. The welded splice joints created an issue during fit-up and welding of the primary bottom in tank SY-101. The plate with the splice resulted in four plates meeting at a single weld joint. Specification B-101-C1 called for no more than three plates to meet at a single weld joint. This issue is identified in 
nonconformance report (NCR) B-101-25-2307-10, included as App Figure C-15. The suggested disposition and justification in NCR B-101-25-2307-10 was as follows:

"Accept as is since joint is permitted by ASME Section VIII, and all welds will receive visual, liquid penetrant (before and after stress relief), and radiographic examination. In addition, each weld seam shall be liquid penetrant examined on the tank exterior surface for a minimum distance of twelve inches from point of junction."

The other plate found to be out-of-tolerance was used in primary tank SY-103. NCR B-101-262307-11 (see Appendix C, App Figure C-16). was generated and the plate accepted as is using the same disposition and justification as in NCR B-101-25-2307-10 above

\subsubsection{Air Leak During Concrete Dome Pour}

On 10/20/1975 in tank SY-101, the QA log states the following:

"...I noticed that the tank had a leak in it, 1'-0" West of the 42" riser at center, the air and water was bubbling up through the concrete (very slowly).

On 10/27/1975 in tank SY-101, the QA log states the following:

"I accompanied Dex Lien during his field evaluation of water/air bubbling incident on tank 101 dome concrete.”

No further information was located regarding the leak found in the dome of primary tank SY101.

\subsubsection{Primary Tank Bottom Plate Drop}

It was also noted in the QA logs on 11/20/1974 that, “...Primary tank bottom was put in place on 102 tank jack stands (sic). One plate was dropped when one of the four clamps came loose. It fell pointed end first which hit the ground while the other end landed on the 102 secondary tank skirt..." QA personnel checked for damage on both components and found "no apparent damage." There is no further documentation or information regarding this incident.

\subsubsection{Tank Bottom Lowering Swivel Condition}

During the lowering of tank SY-102 primary bottom on 2/10/1975, the QA log states the following, “...Lowering of primary bottom was commenced at 2:00 PM. By end of shift bottom had come down about a foot, and had began (sic) to swivel counter clockwise and to the west..." The deviation measured with a plumb bob was no more than 5/8 in. This condition was noted as being “...not yet intolerable..." The problem was solved on 2/11/1975 by, "Installation of four come-alongs between primary and secondary tanks. 
RPP-RPT-54819, Rev. 0

\subsubsection{Primary and Secondary Shell Tolerances}

Several NCR's, deficiency reports, and QA log entries were found that relate to liner fabrication difficulties. These include out-of-roundness, too small circumference and vertical deviations in the tank walls. They are discussed separately below.

\subsubsection{Tank SY-101}

A deficiency report and two NCR's were generated as a result of an out-of-tolerance circumference in the first shell ring of tank SY-101 secondary liner. NCR B-101-33-2307-18 in Appendix C, App Figure C-17 is the first record of this issue in tank SY-101 on 3/13/1975. The discrepancy and disposition was as follows:

"Discrepancy: The circumference of the Tank 101 secondary shell ring ( $1^{\text {st }}$ course) is 251' 1-13/16”. Specified circumference is 251' 6-9/32” (theoretical), plus or minus two inches. Thus, the shell ring is 2-15/32" smaller in circumference. This present condition may result in all subsequent shell rings placed on this course to be similarly out of tolerance, as emphasis will be placed on maintaining vertical plumbness (sic).

Suggested Disposition and Justification: 'Accept-as-is' - as this condition exists on the secondary shell, permanent storage capacity is not applicable to this situation. Structural integrity and function of the secondary tank as a protective barrier against the release of radioactive material into the environs (sic) is not impaired by this condition.”

Another NCR B-101-35-2307-20 (see Appendix C, App Figure C-18) was generated, relating to this out-of-tolerance circumference issue. The discrepancy and suggested disposition from NCR B-101-35-2307-20 was as follows:

"Discrepancy: On the Tank 101 secondary shell, areas exist where the maximum deviation of the line of intersection from a true straight line exceeds $1 / 2$ inch in a five foot length. (Actual maximum measurement in areas shown is 1-1/16 inches, see attachment.) These deviations, a result of distortions in the shell plate, were fabricated to achieve a plate-to-skirt fit-up, then were locally aggravated by weld repairs. This condition contributed to the smaller circumference of the first shell course. (See NCR B-101-332307-18.)

Suggested Disposition and Justification: 'Accept-as-is' - as the length distortion around the periphery is relatively short, the loading of additional shell is insignificant. Subsequently, the concrete tank cylinder placed against the secondary tank will provide additional support of the shell, due to the embedment of the studs and stiffener rings. These are welded to the tank shell prior to concrete placement. Therefore, the function and integrity of the secondary shell remains unaffected."

Figure 5-9 is the attachment to NCR B-101-35-2307-20 showing the deviations and locations around the tank. Deficiency Report \# 23 in Appendix C, App Figure C-19 describes the circumference as being “...3 1/2” Less than the theoretical circumference. This exceeds the 
tolerance allowance in the dimensional control procedure by 1 1/2" (allowable deviation $=+/$ 2”).

Cause: Bottom knuckle is slightly tipped in and first ring had to be trimmed 3 + inches.”

Tank SY-101 secondary shell deviations were accepted as is based on the dispositions of NCR B-101-33-2307-18 and B-101-35-2307-20.
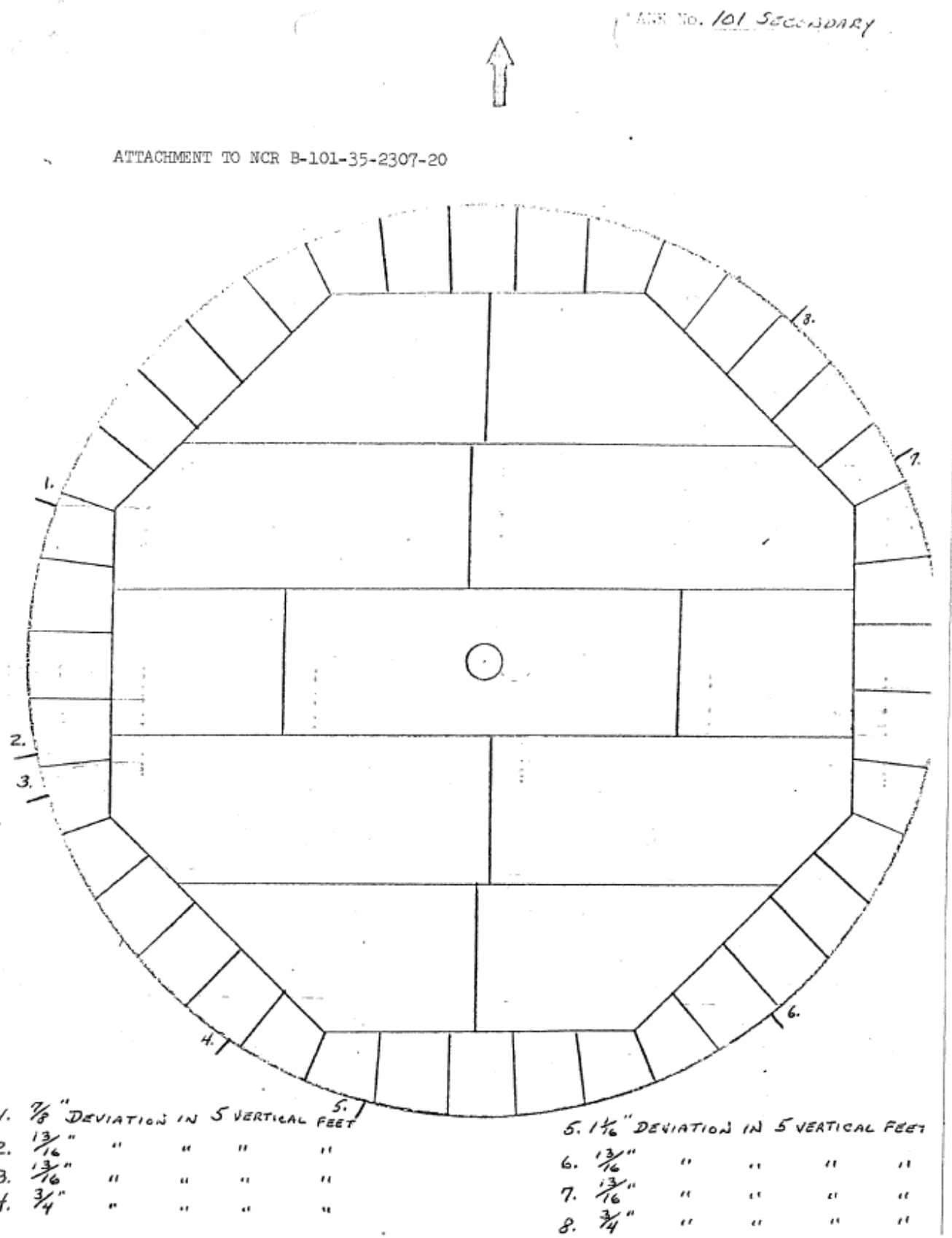

Figure 5-9. Attachment to NCR B-101-35-2307-20 Showing Deviations and Locations 
On 4/2/1975 in tank SY-101 primary shell, the QA log states the following:

“...Diameter measurements on the second course shell ring show it to be out-of-round. Deviation is $61 / 2$ ”, while specified maximum deviation is $41 / 2$ ”. Contractor will attempt to correct this condition with guy wires before beginning 2-3 girth seam."

No NCR was located for this issue. There was no further mention of tank diameter issues in tank SY-101 primary shell QA log after the 2-3 girth seam was welded. It is assumed that the issue was solved after the 2-3 girth seam was welded and the guy wires were removed.

\subsubsection{Tank SY-102}

Measurements taken of the tank SY-102 secondary liner circumference, found the circumference to fall outside of the $+/-2$ in. tolerance.

On 2/24/1975 in tank SY-102 secondary liner, the QA log states the following:

“...the 102 secondary tank measured 251'3-3/8” (6” above bottom of $1^{\text {st }}$ course shell plate) and 251' 2-7/8" (6" above $2^{\text {nd }}$ course shell plate). Design calls for 251'6-9/32" $+/-2 ” . .$.

NCR B-101-29-2307-14 (see Appendix C, App Figure C-20) was generated as a result of the out-of-tolerance circumference. The suggested disposition from NCR B-101-29-2307-14 was as follows:

“Suggested Disposition and Justification: 'Accept-as-is' - as this condition exists on the secondary shell, permanent storage capacity is not applicable to this situation.

Structural integrity and function of the secondary tank as a protective barrier against the release radioactive (sic) material into the environs (sic) is not impaired by this condition."

Deficiency Report \# 20 (see Appendix C, App Figure C-21) states the following:

"Cause: Bottom knuckle is slightly tipped in \& first ring had to be trimmed 3+ inches."

Based on the disposition in NCR B-101-29-2307-14, the non-conformance was accepted as is.

Further tank wall deviations occurred in tank SY-102 secondary liner as a result of initial shell plate distortions. The discrepancy and disposition documented in NCR B-101-31-2307-16 was as follows:

"Discrepancy: On the Tank 102 Secondary shell, (sic) areas exist where the maximum deviation of the line of intersection from a true straight line exceed 1/2 inch in 5 feet length. (Actual measurements in areas shown are 1-1/16 inch maximum in 5 vertical feet.) These deviations (see attachment), a result of distortions in the shell plate, were 
fabricated to achieve a plate-to-skirt fit-up. This condition primarily contributed to the smaller circumference of the first shell course (see NCR B-101-29-2307-14).

Suggested Disposition and Justification: 'Accept-as-is' ...as the length distortion around the periphery is relatively short, the loading of additional shell courses is insignificant. Subsequently, the concrete tank cylinder placed against the secondary tank will provide additional support of the shell itself, due to the embedment of the studs and stiffener ring. Therefore, the function and integrity of the secondary shell remains unaffected."

The cause of the deviation was shop fabricated knuckles having a bend angle of more than $90^{\circ}$. The condition existed on 3 secondary tank knuckles. For the primary tank knuckles the rings were installed in the field which corrected the problem. Figure 5-10 is the attachment to NCR B101-29-2307-16 which shows a diagram of the out-of-tolerance condition as well as the locations of the out-of-tolerance issue around the tank.

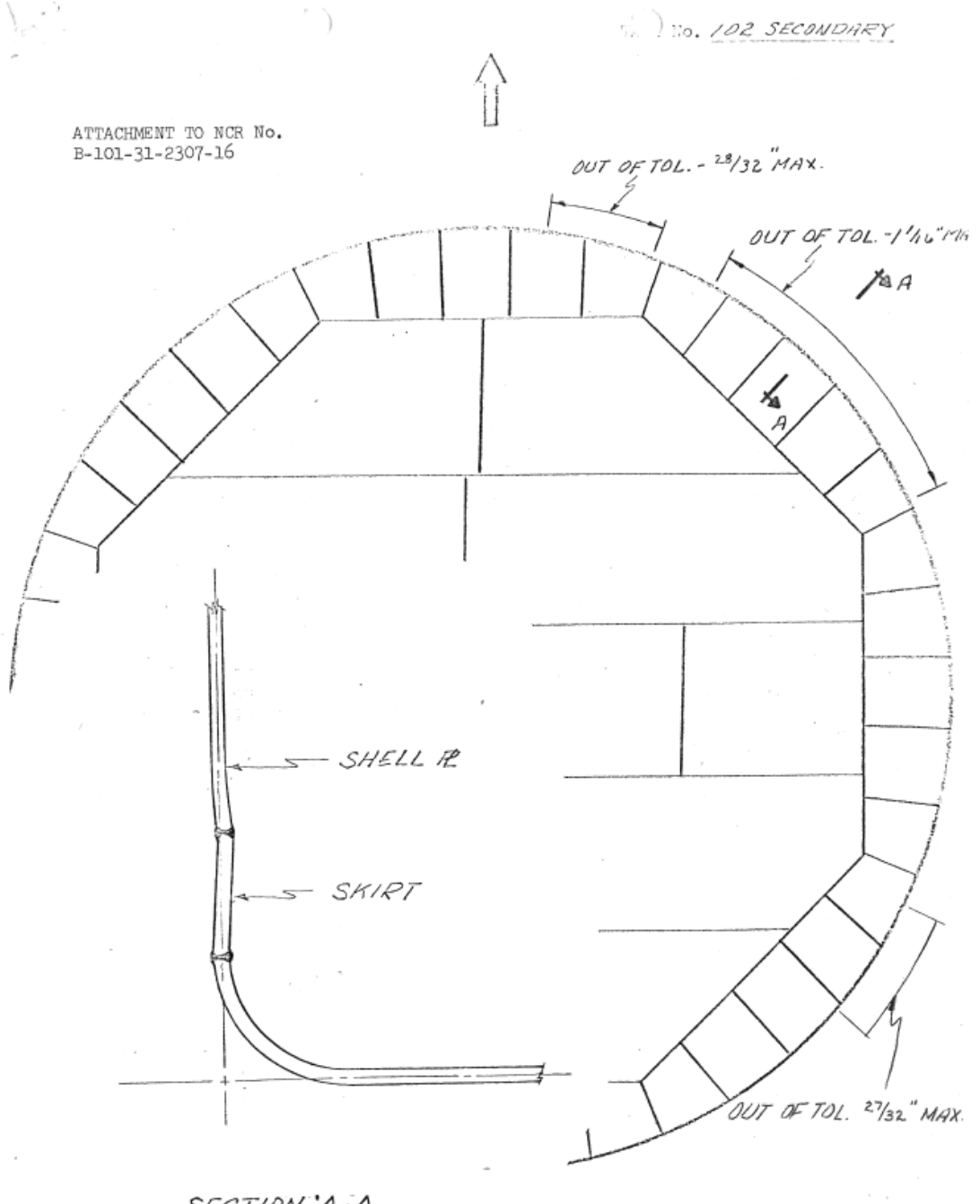

SECTION'A-A

Figure 5-10. Attachment to NCR B-101-29-2307-16 Showing Out-of-Tolerance Locations 
On 3/21/1975 in primary tank SY-102, the QA log states the following:

"Diameter measurements on the $2^{\text {nd }}$ shell ring show it to be out-of-round. The Vitro field survey crew took measurements this A.M, (sic) and found the difference between minimum and maximum diameters to be $63 / 8$ ". Specified maximum deviation is $41 / 2$ ”. These measurements were taken after the contractor had installed a guy line to minimize the distortion..."

A follow up QA log on 3/25/1975 for primary tank SY-102 states the following:

“...Conctractor now has 3 guy lines attached to $2^{\text {nd }}$ shell ring, and says he was able to bring distortion back within tolerance. He has since slacked off on guy lines to avoid stresses while making repairs to 0-1 and 1-2 girth seams."

The next day on 3/26/1975, the QA log states the following:

“...CB\&I has diameter deviation on $2^{\text {nd }}$ shell ring down to $31 / 2$ ” by use of temporary attachments. (Specified tolerance is $41 / 2$ "). The plan is to maintain this condition until 2-3 girth seam is welded, then release temporary attachments."

No NCR related to this specific issue was located. No further mention of primary tank SY-102 out of roundness is documented in the QA log after the 2-3 girth seam. It is assumed that the issue was resolved with the welding of the 2-3 girth seam.

\subsubsection{Tank SY-103}

Measurements taken of the tank SY-103 secondary liner circumference, found the circumference to fall outside of the +/- 2 in. tolerance. This issue was documented in Deficiency Report \# 23 (see Appendix C, App Figure C-19) with tank SY-101. The report describes the deficiency as follows:

"Description: The circumference of the secondary tanks \#101 \& 103 is 3 1/2" less than the theoretical circumference. This exceeds the tolerance allowance in the dimensional control procedure by 1 1/2" (allowable deviation = +/- 2”.)

Cause: Bottom knuckle is slightly tipped in \& first ring had to be trimmed 3+ inches.”

The deficiency was resolved on 5/14/1975 using the following corrective action:

1. “Leave secondary circumferences on tk. 101 \& 103 as is for all shell rings.

2. Customer to evaluate the consequences of (1) above based on their requirements.

3. Customer to allow or reject the 'leave as is' resolution based on (2) above”

No NCR specific to this this issue was found. 
In tank SY-103, a section in the fourth shell ring plate of the primary shell was noted to have exceeded vertical distortion tolerance. Deficiency Report \# 31 (see Appendix C, App Figure C-23) describes the deficiency and cause as follows:

"Description: Local area noted on attached sketch exceeds local distortion tolerances of 1/2” noted in Vitro specifications B-101-C1 Par. \#14-2-E.

Cause: Due to the pressure created while fitting \& welding make up roof plate. This area was checked for tolerances before roof plates were erected \& they checked out ok"

Figure 5-11 is the attachment to Deficiency Report \# 31 showing the local vertical distortion location and magnitude.

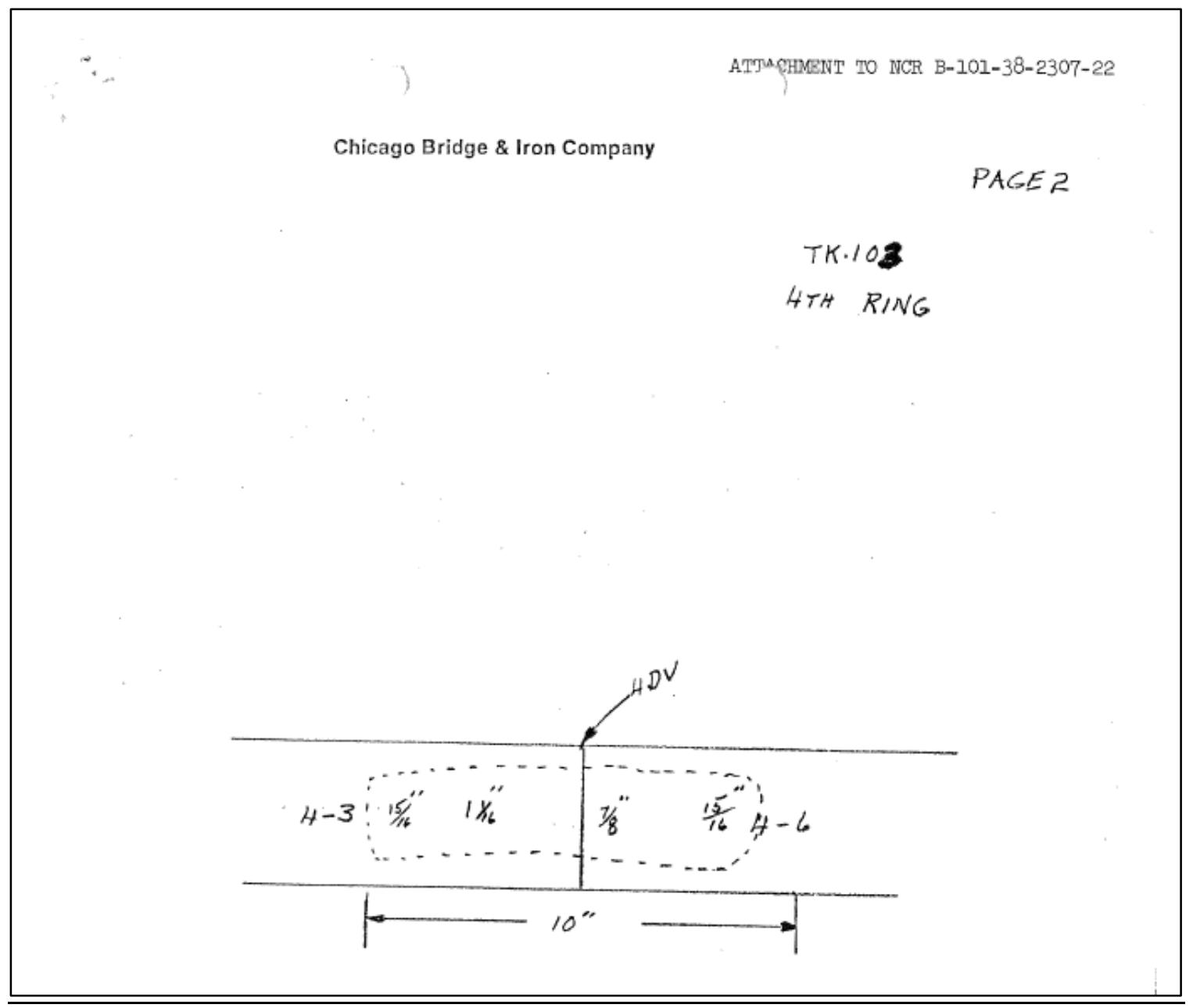

Figure 5-11. Attachment to Deficiency Report \# 31 Showing Out-of-Tolerance Condition 
The corrective action from Deficiency Report \# 31 is as follows:

1. Place area on hold.

2. CB\&I recommends (sic) to customer to leave area as is for the following reasons.

A. ASME does not address itself to localized deformations.

B. ASME, Section VIII, Division I, Section UG-80 does address itself to pressure vessel out of roundness of cylindrical shells. Tolerances given are $1 \%$ of diameter which is met. Allowable for this tank would be approximately 8 ".

C. Specification diameter tolerances are met.

D. Shell sweep board tolerances are met

E. With the existing localized deformation the tank remains structurally sound and will not have any detrimental effects during or after further fabrication operations (stress relief \& dome concreting).

F. Any cosmetic value will be lost after the tank is enclosed.

G. Repair of the area would entail cutting vertical and horizontal seams with extra buildup of plate edges and rewelding which based on previous similar repairs would create greater distortions than exist.

3. Customer to allow or reject the leave as is resolution based on 2 above."

The deficiency was accepted as is on 8/6/1975 based on the criteria 1 through 6 listed in NCR B101-38-2307-22 attachment 1 (see Appendix C, App Figure C-24).

\subsubsection{Tank Dome Drooping}

On 5/8/1975 the QA log states the following:

"Several efforts have been made to erect the first section of dome plate. To date, these efforts have been unsuccessful. When lifted by crane hoist, dome plate droops enough so that contractor has not been able to position it correctly."

There was no mention of a corrective action related to this issue. However On 5/13/1975 the QA log states the following:

“...One section of the dome plates was erected and tacked in place."

Based on the 5/13/1975 QA log, it is assumed that lifting issues were resolved.

Two areas of tank SY-102 primary tank dome exhibited deformations after installation. The issue was documented in NCR B-101-37-2307-21 (see Appendix C, App Figure C-25), which states the following:

"Discrepancy: Two areas of 102 Primary tank dome exhibit flat spots and reverse curvature (see attached sketch for location). Maximum deformation from theoretical curvature does not exceed 1 ".

Suggested Disposition and Justification: 'accept-as-is' since dome plate will be restrained by installation of 6 " $\times 4$ " $\times 3 / 8$ ” angle to be welded to roof for temporary 
support during stress relieving. Installation of these angles are shown on contractor drawing HT 9, Rev. 2.”

The suggested disposition from NCR B-101-37-2307-21 did not accomplish the desired purpose and another NCR was generated. NCR B-101-39-2307-23 (see Appendix C, App Figure C-26) states the following:

\begin{abstract}
"Discrepancy: Suggested disposition, as called out on NCR B-101-37-2307-21, did not accomplish desired purpose. Although temporary angles provided support during stress relief, the dome sagged upon their removal. Deviation from theoretical curvature is now approximately 2-1/2".

Without correction, further deflection could be expected when concrete and reinforcing steel is installed.
\end{abstract}

Suggested Disposition and Justification: Disposition as per attached contractor's suggestion. The present deflection results in no unworkable problems. Operation of completed facility will not be impaired. The proposed additional support will prevent any additional deflection."

Figure 5-12 is the attachment to NCR B-101-37-2307-21 which shows the locations of dome deviation in tank SY-102. The following sequence was used to stiffen the roof:

1. "Install and weld complete the dollar plate.

2. Leave all stiffening presently in place until flat spot has been pulled up and secured.

3. Refer to attached Sheet \#1 for stiffening details. Install circumferential stiffeners and weld complete. If depressed area extends inside 17'-6" radius or outside 22'6" radius, additional circumferential stiffeners will be required.

4. Install all radial stiffeners required and weld them to circumferential angles.

5. Pull roof plate up to radial stiffeners and weld. If additional circumferential angles are required, span between them with additional radial stiffeners.

6. If above system stabilizes the roof in this area, remove all other stiffening from roof. 
7. Stiffening at depressed spot must remain in place through concreting. If customer will not accept this, then we will have to stiffen the underside of the roof and remove this stiffening after concrete is set up."

There is no further information on this non-conformance. It is assumed that the stiffening sequence resolved the dome non-conformance.

\subsubsection{Concrete Issues}

On 10/28/1975 in tank SY-103, the QA log states the following:

“...There were some spots of honey comb...they were very shallow, and they were cut out and repaired imediately (sic) which I witnessed. I also witnessed clean up on the dome for the remaining concrete pour. "

There was no further information regarding honey comb in the concrete.

\subsubsection{Tank Elevations}

On 9/30/1974, The following is written in the QA log:

"...Vitro survey checked the high-low elevation on the insulating concrete, tank 102. The design elevation is 617.20' with a maximum tolerance of (+/-) 1/4". The maximum deviation from the design elevation was (+/-) 1/2"..."

There was no further documentation of this incident in the QA logs, and the NCR was not located. 


\subsection{CONCLUSION}

The leak assessment report for tank AY-102, RPP-ASMT-53793, identified first-of-a-kind construction difficulties and trial-and-error repairs that compromised the intended robustness of the tank. A review of the construction records for the 241-SY tank farm was completed to determine if similar or other difficulties were experienced during construction of the 241-SY double-shell tanks.

It is apparent that the 241-SY tank farm had similar difficulties in primary and secondary steel tank construction. Table 6-1 compares the issues seen in 241-AY-102 and the 241-SY tank farm.

The 241-SY tank farm experienced high primary tank bottom weld rejection rates of $22 \%$ 30.1\%. Rejected welds were repaired and eventually accepted. Post-weld stress relief was successfully completed without incident.

Weld rejection is thought to be a contributor to the out-of-tolerance distortions, or bulges, found in tanks SY-101, SY-102 and SY-103 secondary liner bottoms, and tank SY-101 and SY-103 primary tank bottoms. The bulges in the secondary liner bottoms of tanks SY-101, SY-102 and SY-103 will compress under a filled primary tank, which could lead to cracking of the refractory.

All three tanks experienced secondary liner bulges that were eventually accepted "as is." Significant primary tank bulges were also present in tanks SY-101 and SY-103. The bulges in primary tank SY-101 bottom were supported by chipping out the refractory beneath the bulge and using grout to fill in the areas up to the out-of-tolerance distortions. For SY-103, strain gauge testing, acoustic testing, and structural analysis were conducted to show that the stresses were not a threat.

Damage and repairs to the refractory were minor. The castable refractory was protected from freezing during construction, reducing the extent of rework. Minor cracking was found around some of the cribbing supports, and one bad area was repaired prior to lowering the primary tank bottom.

New issues, not experienced during construction of either the 241-AY or 241-AZ double-shell tanks occurred in 241-SY tank farm construction. During the lowering process of tank SY-102 secondary liner bottom, distortions of up to $18 \mathrm{in}$. were noted. No permanent distortions were left in the secondary liner bottom, and the non-conformance was conditionally accepted after the secondary liner passed liquid penetrant examination.

Numerous difficulties were experienced during erection of the secondary and primary liners, including weld splice joints exceeding the design specification, secondary shell tolerance issues with circumferences and vertical plate deviations, temporary out-of-round conditions on primary liners, and “drooping" sections of the primary dome plates. Ultimately, all these conditions were either corrected or accepted on the basis that structural integrity was not affected.

The 241-SY tank farm had improved construction practices in some areas as compared to tank AY-102, yet many of the construction issues experienced by tank AY-102 re-emerged. Overall, 
the condition of the tank liners in the 241-SY tank farm are considered to be similar to tank AY102. Factors thought to have caused unsupported areas in the primary tank bottom and the potential for areas of high residual stress in tank AY-102 are also present in all of the 241-SY tank farm tanks.

Table 6-1. Summary Comparison 241-SY Tank Farm Construction to Tank AY-102

\begin{tabular}{|c|c|c|c|c|}
\hline Tank & AY-102 & SY-102 & SY-101 & SY-103 \\
\hline $\begin{array}{l}\text { Evaluation } \\
\text { Document }\end{array}$ & $\begin{array}{l}\text { RPP-ASMT-53793, } \\
\text { Tank 241-AY-102 } \\
\text { Leak Assessment } \\
\text { Report }\end{array}$ & \multicolumn{3}{|c|}{$\begin{array}{l}\text { RPP-RPT-54819, 241-SY Tank Farm Construction Extent of } \\
\text { Condition Review for Tank Integrity }\end{array}$} \\
\hline $\begin{array}{l}\text { Construction } \\
\text { Order }\end{array}$ & $1^{\text {st }}$ DST constructed & $1^{\text {st }}$ DST in $3^{\text {rd }}$ Farm & 2nd DST in $3^{\text {rd }}$ Farm & 3rd DST in $3^{\text {rd }}$ Farm \\
\hline $\begin{array}{l}\text { Construction } \\
\text { Contractor }\end{array}$ & $\begin{array}{l}\text { Pittsburgh-Des } \\
\text { Moines (PDM)Steel } \\
\text { Company }\end{array}$ & \multicolumn{3}{|c|}{ Chicago Bridge and Iron (CBI) Company } \\
\hline $\begin{array}{l}\text { Secondary Bottom } \\
\text { Material }\end{array}$ & $\begin{array}{l}\text { 0.25-in. plate, } \\
\text { ASTM A515, Gr } 60\end{array}$ & \multicolumn{3}{|c|}{ 0.375-in. plate, ASTM A516, Gr 65} \\
\hline \multirow[t]{2}{*}{$\begin{array}{l}\text { Secondary Liner } \\
\text { Bottom Bulges }\end{array}$} & \multirow[t]{2}{*}{$\begin{array}{l}\text { Excessive distortion } \\
\text { and bulges noted } \\
\text { throughout. } \\
\text { Maximum slope } \\
\text { noted as much as 1- } \\
\text { in./ft. } 22 \text { places } \\
\text { exceed 2-in. peak- } \\
\text { to-valley tolerance. }\end{array}$} & $\begin{array}{l}\text { Out of tolerance in } \\
\text { several areas, up to } \\
0.8125 \text {-in./ft. NCR } \\
\text { generated. } \\
\text { Flattening } \\
\text { unsuccessful. }\end{array}$ & $\begin{array}{l}\text { Out of tolerance in } \\
\text { several areas, up to } \\
0.625 \text {-in./ft. NCR B- } \\
\text { generated. }\end{array}$ & $\begin{array}{l}\text { Weld pattern } \\
\text { changed, still out of } \\
\text { tolerance, up to 1- } \\
\text { in./ft. NCR } \\
\text { generated. Flattening } \\
\text { attempts } \\
\text { unsuccessful, } \\
\text { including a } 6000 \text { lb. } \\
\text { weight. }\end{array}$ \\
\hline & & \multicolumn{3}{|c|}{$\begin{array}{l}\text { All SY farm secondary bulges accepted based on liquid penetrant } \\
\text { tests after lowering and inspection and repair of refractory cracks and } \\
\text { depressions after partial loading. Out of tolerance areas are } \\
\text { localized. }\end{array}$} \\
\hline $\begin{array}{l}\text { Primary Bottom } \\
\text { Material }\end{array}$ & $\begin{array}{l}0.375 \text {-in. plate, } \\
\text { ASTM 515, Gr } 60\end{array}$ & \multicolumn{3}{|c|}{ 0.5-in. plate, ASTM A516, Gr 65} \\
\hline & $33.8 \%$ & $21.9 \%$ & $30.1 \%$ & $25.7 \%$ \\
\hline $\begin{array}{l}\text { Primary Bottom } \\
\text { Weld Rework }\end{array}$ & $\begin{array}{l}\text { Ultimately all welds } \\
\text { were accepted and } \\
\text { stress relieved, } \\
\text { although problems } \\
\text { with that process } \\
\text { were noted. }\end{array}$ & \multicolumn{3}{|c|}{ Ultimately all welds were accepted and stress relieved. } \\
\hline
\end{tabular}




\begin{tabular}{|c|c|c|c|c|}
\hline Tank & AY-102 & SY-102 & SY-101 & SY-103 \\
\hline $\begin{array}{l}\text { Primary Liner } \\
\text { Bottom Bulges }\end{array}$ & $\begin{array}{l}\text { Primary bottom } \\
\text { flatness described as } \\
\text { "generally good.” }\end{array}$ & $\begin{array}{l}\text { Out of tolerance } \\
\text { areas noted until } \\
\text { primary was } \\
\text { lowered and found } \\
\text { acceptable. }\end{array}$ & $\begin{array}{l}\text { Out of tolerance areas } \\
\text { noted and plate } \\
\text { repairs performed, } \\
\text { causing new out of } \\
\text { tolerances, maximum } \\
\text { bump height of } 0.26 \\
\text { ft. and bottom grouted } \\
\text { in two locations to } \\
\text { support primary. }\end{array}$ & $\begin{array}{l}\text { Out of tolerance in } \\
\text { several areas, up to } \\
\text { 0.8125-in./ft. NCR } \\
\text { generated. Later } \\
\text { accepted based on } \\
\text { strain gauge } \\
\text { monitoring and } \\
\text { acoustic testing } \\
\text { during hydro test, } \\
\text { which showed } \\
\text { stresses to be } \\
\text { acceptable }\end{array}$ \\
\hline $\begin{array}{l}\text { Stress Relieving } \\
\text { Process }\end{array}$ & $\begin{array}{l}\text { Required } 2 \text { days to } \\
\text { remove all the water } \\
\text { in the refractory and } \\
\text { temperature } \\
\text { recorder just prior to } \\
\text { initiating } 3 \text { hour } \\
\text { hold time was } 915^{\circ} \mathrm{F} \\
\text { (accepted as being } \\
\left.1000^{\circ} \mathrm{F}\right) \text {. }\end{array}$ & $\begin{array}{l}\text { One hour hold at } \\
1100^{\circ} \mathrm{F} \text {. } \\
\text { Minor steaming } \\
\text { from refractory } \\
\text { noted during heat } \\
\text { up. }\end{array}$ & $\begin{array}{l}\text { Three hour hold at } \\
1000^{\circ} \mathrm{F} \text {. }\end{array}$ & $\begin{array}{l}\text { One hour hold at } \\
1100^{\circ} \mathrm{F} \text {. }\end{array}$ \\
\hline Refractory & Kaolite 2200-LI & \multicolumn{3}{|c|}{ Lite-Wate 50} \\
\hline $\begin{array}{l}\text { Refractory } \\
\text { Protection }\end{array}$ & $\begin{array}{l}\text { Allowed to saturate } \\
\text { with rain water, not } \\
\text { protected from } \\
\text { freezing. }\end{array}$ & \multicolumn{2}{|c|}{$\begin{array}{l}\text { Temporary heating grid installed and } \\
\text { covered. }\end{array}$} & $\begin{array}{l}\text { Weather allowed to } \\
\text { warm before pour }\end{array}$ \\
\hline $\begin{array}{l}\text { Refractory } \\
\text { Condition }\end{array}$ & $\begin{array}{l}\text { After hydro test } \\
\text { refractory found to } \\
\text { be degraded, } \\
\text { extensively cracked } \\
\text { and spalled. } \\
\text { Samples showed } \\
\text { excessive } \\
\text { carbonation. }\end{array}$ & $\begin{array}{l}\text { Inspected after } \\
\text { hydro test and } 3 \\
\text { areas of minor } \\
\text { damage noted, no } \\
\text { repairs after hydro } \\
\text { test }\end{array}$ & $\begin{array}{l}\text { No reports on post } \\
\text { hydro test inspection } \\
\text { were found }\end{array}$ & $\begin{array}{l}\text { No reports on post } \\
\text { hydro test inspection } \\
\text { were found, NCR B- } \\
101-32-2307-17 \text { on } \\
\text { out-of-level } \\
\text { condition } \pm 1 \text { in vs. } \\
\text { spec of } \pm 1 / 4 \text { in, } \\
\text { accepted “as-is” }\end{array}$ \\
\hline Refractory Repair & $\begin{array}{l}21 \text { inches of } \\
\text { perimeter removed } \\
\text { and replaced with } \\
\text { concrete and rebar }\end{array}$ & $\begin{array}{l}\text { Minor damage } \\
\text { from primary liner } \\
\text { support cribbing, 5- } \\
\text { ft. by } 8 \text {-ft. by 2.5- } \\
\text { in. area replaced. }\end{array}$ & $\begin{array}{l}\text { Minor repairs made } \\
\text { during initial pour, } \\
\text { none after post weld } \\
\text { stress relieving. }\end{array}$ & None reported \\
\hline
\end{tabular}




\begin{tabular}{|c|c|c|c|c|}
\hline Tank & AY-102 & SY-102 & SY-101 & SY-103 \\
\hline Other Issues & $\begin{array}{l}\text { Unsupported areas } \\
\text { of primary bottom } \\
\text { filled with foam. }\end{array}$ & $\begin{array}{l}\text { Lack of control } \\
\text { during lowering of } \\
\text { secondary bottom } \\
\text { led to distortions of } \\
\text { up to 18-in, } \\
\text { Accepted based on } \\
\text { actions identified } \\
\text { for secondary } \\
\text { bulges (penetrant } \\
\text { examination, } \\
\text { refractory } \\
\text { examination and } \\
\text { repair after partial } \\
\text { loading). }\end{array}$ & $\begin{array}{l}\text { Primary bottom had } \\
\text { four plates meet at a } \\
\text { weld junction. } \\
\text { Specification calls for } \\
\text { no more than three. } \\
\text { Accepted based on } \\
\text { ASME Boiler and } \\
\text { Pressure Vessel Code } \\
\text { (allowed four) and } \\
\text { weld NDE. }\end{array}$ & $\begin{array}{l}\text { Primary bottom had } \\
\text { four plates meet at a } \\
\text { weld junction. } \\
\text { Specification calls for } \\
\text { no more than three. } \\
\text { Accepted based on } \\
\text { ASME Boiler and } \\
\text { Pressure Vessel Code } \\
\text { (allowed four) and } \\
\text { weld NDE. }\end{array}$ \\
\hline $\begin{array}{l}\text { Overall } \\
\text { Conclusion on } \\
\text { Construction } \\
\text { Difficulties }\end{array}$ & $\begin{array}{l}\text { Difficultly with liner } \\
\text { fabrication and the } \\
\text { castable refractory } \\
\text { left the tank with } \\
\text { unsupported areas in } \\
\text { the tank bottom and } \\
\text { unexpected residual } \\
\text { stresses in the tank } \\
\text { bottom that } \\
\text { probably } \\
\text { contributed to } \\
\text { failure. }\end{array}$ & \multicolumn{3}{|c|}{$\begin{array}{l}\text { A new contractor (CBI) was employed for the third DST farm } \\
\text { constructed. Some improvement was seen in issues related to } \\
\text { refractory construction, weather protection, and post-weld stress } \\
\text { relieving processes. Other difficulties identified as contributing } \\
\text { factors in tank AY-102, returned. These included a high weld rework } \\
\text { rate, nearly as high as tank AY-102 and higher than the other DSTs } \\
\text { examined so far. The most significant construction issue was the lack } \\
\text { of bottom flatness with secondary liner bottoms as well as primary } \\
\text { bottoms. "Trial and Error" repairs of this issue were attempted and } \\
\text { eventually bulges were accepted, either by extensive testing and } \\
\text { analysis (SY-103) or by grouting the worst areas (SY-101). Those } \\
\text { factors that caused unsupported areas and the potential for areas of } \\
\text { high residual stress in tank AY-102 are present in all of the SY farm } \\
\text { tanks. }\end{array}$} \\
\hline
\end{tabular}


RPP-RPT-54819, Rev. 0

\subsection{REFERENCES}

ARH-2930, 1973, Functional Design Criteria Salt Cake Storage Facilities 241-SY Tank Farm, Atlantic Richfield Hanford Company, Richland, Washington.

ARH-CD-580, 1976, Technical Record of the 241-SY-103 Primary Tank Bottom Flatness Studies, Atlantic Richfield Hanford Company, Richland, Washington.

ARH-LD-146, 1976, Technical Record of the 2412-SY-103 Primary Tank Bottom Flatness Studies, Atlantic Richfield Hanford Company, Richland, Washington.

ARH-R-172, 1974, Analysis of Underground Waste Storage Tanks 241-SY at Hanford Washington, John A. Blume \& Associates, Engineers, San Francisco, California.

ASME, 1971 Edition thru 1973 addenda, Boiler and Pressure Vessel, American Society of Mechanical Engineers, New York, New York.

ASTM, 2012, Standard Specification for Portland Cement, American Society for Testing and Materials, West Conshohocken, Pennsylvania.

B-101-C1, 1973, Specifications for Primary and Secondary Steel Tanks Project B-101 241-SY Tank Farm, Automation Industries Inc. Vitro Engineering Division, Richland, Washington.

B-101-C2, 1974, Specifications for Excavation and Tank Foundations 241-SY Tank Farm Project B-101, Automation Industries Inc. Vitro Engineering Division, Richland, Washington.

B-101-C3, 1974, Construction Specification for Completion of 241-SY Tank Farm Project B101, Automation Industries Inc. Vitro Engineering Division, Richland, Washington.

BNWL-B-471, 1976, Strain Survey from a Hydrotest of the Primary Waste Tank 241-SY-103, Battelle Pacific Northwest Laboratories, Richland, Washington.

BNWL-B-475, 1976, Computer-Based Structural Investigation of the SY-103 Waste Storage Tank Which Contains an Out-of-Tolerance Bottom Bump, Atlantic Richfield Hanford Company, Richland, Washington.

H-14-010531, 2010, “Dome Penetration Schedules (WST/WSTA) Tank 241-SY-102,” Sheet 2, Rev. 15, Washington River Protection Solutions LLC, Richland, Washington.

H-14-010531, 2010, “Dome Penetration Schedules (WST/WSTA) Tank 241-SY-103,” Sheet 3, Rev.8, Washington River Protection Solutions LLC, Richland, Washington.

H-14-010531, 2013, “Dome Penetration Schedules (WST/WSTA) Tank 241-SY-101,” Sheet 1, Rev. 12, Washington River Protection Solutions LLC, Richland, Washington. 
H-2-37704, 1974, “Structural Concrete Tank Foundation Plan and Details,” Automation Industries Inc. Vitro Engineering Division, Richland, Washington.

H-2-37705, 1973, “ Structural Insulating Concrete Plan and Details,” Automation Industries Inc. Vitro Engineering Division, Richland, Washington.

H-2-37706, 1974, “ Concrete Tank Section and Haunch Reinforcement,” Automation Industries Inc. Vitro Engineering Division, Richland, Washington.

H-2-37772, 1973, “Tank Cross Section 241-SY Tank Farm,” Vitro Hanford Engineering Services, Richland, Washington.

HPS-210-W, 1973, Standard Specification for Qualifying Special Process Welding Personnel, ERDA, Richland, Washington.

HPS-220-W, 1973, Standard Specification for Welding Carbon Steel Plate, ERDA, Richland, Washington.

HPS-240-W, 1973, Standard Specification for Stud Welding, Energy Research and Development Agency, Richland, Washington.

HWS-7791, 1968, Specification for Side Walls and Dome Nuclear Waste Storage Tank Project IAP-614 Purex Tank Expansion, Hanford Engineering Services, Richland, Washington.

Mehta, P. Kumar, and Monteiro, Paulo J.M., 1993, Concrete Microstructures, Properties, and Materials, McGraw-Hill Companies, New York.

RPP-19097, 2003, Evaluation of Insulating Concrete in Hanford Double-Shell Tanks, CH2MHILL Hanford Group, Inc., Richland, Washington.

RPP-ASMT-53793, 2012, Tank 241-AY-102 Leak Assessment Report, Washington River Protection Solutions, LLC, Richland, Washington.

RPP-RPT-54818, 2013, 241-AZ Tank Farm Construction Extent of Condition for Tank Integrity, Washington River Protection Solutiongs, LLC, Richland, Washington.

VITRO-R-350, 1975, Tank Bottom Flatness Engineering Study (Interim Report),Automation Industries Inc, Vitro Engineering Division, Richland, Washington.

VITRO-R-389, 1975, Strain Gage Activity Relating to Primary Tank 241-SY-103, Automation Industries Inc, Vitro Engineering Division, Richland, Washington.

XN-331, 1975, Technical Report for NDT - Acoustics Testing of the Primary Shell of Atlantic Richfield Hanford Company Tank 103, Exxon Nuclear Company, Inc. Richland, Washington 
RPP-RPT-54819, Rev. 0

APPENDIX A 241-SY FARM KEY EVENT TABLE 
RPP-RPT-54819, Rev. 0

\begin{tabular}{|c|c|c|c|c|c|}
\hline No. & Date & $\begin{array}{l}\text { Initials of } \\
\text { Inspector }\end{array}$ & Tank & Comments & Event Type \\
\hline 1. & $12 / 31 / 73$ & AWA & & Steel purchase specification issued. & Construction \\
\hline 2. & $1 / 2 / 74$ & AWA & & $\begin{array}{l}\text { Don Nelson directed Al Akerson (AWA) to take } \\
\text { over project management from Edgar F. Smith } \\
\text { due to illness. }\end{array}$ & Construction \\
\hline 3. & $2 / 22 / 74$ & JHP & & Excavation observed. & Construction \\
\hline 4. & $3 / 5 / 74$ & JHP & & $\begin{array}{l}\text { Excavation complete to } 645 \text { feet. Request for pile } \\
\text { driving to begin. }\end{array}$ & Construction \\
\hline 5. & $3 / 13 / 74$ & JHP & & Pile driving began. & Construction \\
\hline 6. & $4 / 30 / 74$ & JHP & & Placed rebar for leak detection pits. & Construction \\
\hline 7. & $5 / 2 / 74$ & JHP & & $\begin{array}{l}\text { Soil failed compaction test } 97 \% \text { with } 16 \% \\
\text { moisture. Un-compacted soil was } 92 \% \\
\text { compaction } \pm 5 \% \text { moisture was unknown. Two } \\
\text { more tests were taken. }\end{array}$ & Issue \\
\hline 8. & $5 / 2 / 74$ & AWA & & $\begin{array}{l}\text { Issue with refractory testing taking more than a } \\
\text { month based on } 241 \text {-AY experience. If required, } \\
\text { the project was going to go back to Kaolite } \\
\text { specified. }\end{array}$ & Issue \\
\hline 9. & $5 / 3 / 74$ & JHP & & $\begin{array}{l}\text { Concrete bases for all three sumps (tertiary leak } \\
\text { detection pits) were poured. }\end{array}$ & Construction \\
\hline 10. & $5 / 3 / 74$ & JGCD & $\begin{array}{l}101, \\
102, \\
\text { and } \\
103\end{array}$ & $\begin{array}{l}\text { Check forms, reinforcing steel, anchor bolts, and } \\
\text { placed five cubic yards of concrete for leak } \\
\text { detector risers on tanks } 101,102 \text {, and } 103 \text {. } \\
\text { Concrete slump was } 31 / 4 \text { ” the pour went very } \\
\text { good. }\end{array}$ & Construction \\
\hline 11. & $5 / 6 / 74$ & JD & $\begin{array}{l}101 \\
\text { and } \\
102\end{array}$ & Placing rebar for Tank 102 and grading for 103. & Construction \\
\hline 12. & $5 / 7 / 74$ & JD & 101 & Compacting 101 base slab. & Construction \\
\hline 13. & $5 / 15 / 74$ & JHP & 102 & Tank 102 drain line didn’t pass spark test. & Issue \\
\hline 14. & $5 / 16 / 75$ & JHP & 102 & Tank 102 drain line passed spark test.. & Issue \\
\hline 15. & $5 / 16 / 74$ & JHP & 102 & $\begin{array}{l}\text { Drain line for } 102 \text { failed its spark test. Covered } \\
\text { with more Bitumaster. }\end{array}$ & Construction \\
\hline 16. & $5 / 17 / 74$ & JHP & 102 & Hydro test and spark test of 102. & Construction \\
\hline
\end{tabular}


RPP-RPT-54819, Rev. 0

\begin{tabular}{|c|c|c|c|c|c|}
\hline No. & Date & $\begin{array}{l}\text { Initials of } \\
\text { Inspector }\end{array}$ & Tank & Comments & Event Type \\
\hline 17. & $6 / 5 / 74$ & JGCD & 102 & $\begin{array}{l}\text { Starting pouring base slab for } 102 \text {. Drop bucket } \\
\text { on four sections of wood drain slots. Slots had to } \\
\text { be brought back to proper elevation. Came close } \\
\text { to getting cold joints. Crew was directed so as to } \\
\text { prevent cold joints. }\end{array}$ & Construction \\
\hline 18. & $6 / 7 / 74$ & JHP & 102 & $\begin{array}{l}\text { Concrete curing continued with use of burlap } \\
\text { blankets and visqueen. }\end{array}$ & Construction \\
\hline 19. & $6 / 7 / 74$ & AWA & & $\begin{array}{l}\text { Tests regarding Lightweight Number } 50 \text { castable } \\
\text { refractory. } \\
\text { - Not enough sample } \\
\text { - Mixture wrong needs more water to be } \\
\text { pourable (.11 pints per pound to } 0.7 \text { pints } \\
\text { per pound) } \\
\text { - Funding }\end{array}$ & Issue \\
\hline 20. & $6 / 14 / 74$ & JHP & 101 & $\begin{array}{l}\text { Soil compaction test obtained and shipped to } \\
\text { batch plant. Started placement of concrete at 9:00 } \\
\text { a.m. and finished at 3:30 p.m. }\end{array}$ & Construction \\
\hline 21. & $6 / 15 / 74$ & JHP & 101 & $\begin{array}{l}\text { Concrete deemed to have acceptably cured cover } \\
\text { with wet blankets and visqueen. }\end{array}$ & Construction \\
\hline 22. & $6 / 17 / 74$ & JPH & & $\begin{array}{l}\text { Backfill changes from } 1 \text { ” to } 3 \text { ” rock. Backfill } \\
\text { being placed in greater than } 8 \text { ” lifts and contractor } \\
\text { not removing rock greater than } 3 \text { ”. }\end{array}$ & Issue \\
\hline 23. & $6 / 18 / 74$ & JPH & & $\begin{array}{l}\text { Compaction test form } 6 / 14 \text { failed area re- } \\
\text { compacted. Another test done and accepted as is } \\
\text { at } 92 \% \text { to } 93 \% \text { as compared the required } 95 \% \text {. }\end{array}$ & Issue \\
\hline 24. & $6 / 24 / 74$ & RAN & 103 & Thermocouples placed. & Construction \\
\hline 25. & $6 / 26 / 74$ & JHP & 103 & $\begin{array}{l}\text { Concrete for Tank } 103 \text { was poured starting 7:00 } \\
\text { a.m. and finishing at } 3: 30 \mathrm{p} . \mathrm{m} \text {. Temperatures } \\
\text { ranged from between } 60^{\circ} \mathrm{F} \text { and } 80^{\circ} \mathrm{F} \text {. }\end{array}$ & Construction \\
\hline 26. & $6 / 26 / 74$ & JGCD & 103 & $\begin{array}{l}\text { First two loads were dry ( } 21 / 2 \text { ” of slump). Batch } \\
\text { plant added } 1 \text { gallon per cubic foot and the } \\
\text { problem was fixed. } 369 \text { cubic yards were place } \\
\text { by 3:15 p.m. }\end{array}$ & Issue \\
\hline 27. & $7 / 4 / 74$ & JGCD & 103 & $\begin{array}{l}\text { Inspected slabs found curing cracks from the } \\
\text { surface drying too fast. }\end{array}$ & Issue \\
\hline 28. & $7 / 29 / 74$ & $\mathrm{JH}$ & & $\begin{array}{l}\text { Plates and knuckle sections arrive at site. Knuckle } \\
\text { section stress relieved prior to radiograph } \\
\text { inspections of the weld. Grinding and repair was } \\
\text { performed after stress relieved. }\end{array}$ & Issue \\
\hline
\end{tabular}


RPP-RPT-54819, Rev. 0

\begin{tabular}{|c|c|c|c|c|c|}
\hline No. & Date & $\begin{array}{l}\text { Initials of } \\
\text { Inspector }\end{array}$ & Tank & Comments & Event Type \\
\hline 29. & 7/30/74 & $\mathrm{JH}$ & & $\begin{array}{l}\text { CBI confirmed the observation cited the } \\
\text { specification B-101-C1, Section 13.0a, page 17; } \\
\text { which states the knuckle plates shall be stressed } \\
\text { relieved after forming and prior to shipment. }\end{array}$ & Issue \\
\hline 30. & $7 / 31 / 74$ & $\mathrm{JH}$ & 102 & $\begin{array}{l}\text { Welding began on Tank } 102 \text { secondary liner } \\
\text { without an approved procedure. Deemed visually } \\
\text { acceptable. }\end{array}$ & Construction/Issue \\
\hline 31. & $8 / 2 / 74$ & $\mathrm{JH}$ & 102 & $\begin{array}{l}\text { Worked continued without approved procedures. } \\
\text { One weld was removed because it didn't comply } \\
\text { with the unapproved procedure. A wash pass } \\
\text { weld was used to restore the edge as opposed to } \\
\text { stringer bead. }\end{array}$ & Issue \\
\hline 32. & $8 / 12 / 74$ & $\mathrm{JH}$ & 102 & Weld number 4-A-L \#1 was cut out for distortion. & Issue \\
\hline 33. & $8 / 13 / 74$ & $\mathrm{JH}$ & & Weld procedures approved with exceptions. & Construction \\
\hline 34. & $8 / 16 / 74$ & $\mathrm{JH}$ & 101 & $\begin{array}{l}\text { Two repairs and several re-shots were required on } \\
\text { Tank } 101 .\end{array}$ & Issue \\
\hline 35. & $8 / 20 / 74$ & $\mathrm{JH}$ & & $\begin{array}{l}\text { All welds requiring repair complied with ASME } \\
\text { V, } 1974 \text { Edition, Including the summer of } 74 \\
\text { Addenda. }\end{array}$ & Construction \\
\hline 36. & $8 / 23 / 74$ & $\mathrm{JH}$ & 102 & $\begin{array}{l}\text { Shop fabricated knuckle, Section } 4-\mathrm{A}-\mathrm{V} \text {, was off } \\
\text { by } 11 / 4 \text { “. The subcontractor cut out a } 12 \text { " section } \\
\text { and inserted a piece of plate to comply with the } \\
\text { weld geometry requirements. }\end{array}$ & Issue \\
\hline 37. & $8 / 29 / 74$ & AWA & & Project $8.4 \%$ complete due by $1 / 1 / 76$. & Construction \\
\hline 38. & $9 / 5 / 74$ & $\mathrm{JH}$ & 103 & $\begin{array}{l}\text { Two sections rejected that had been accepted by } \\
\text { the sub-contractor. }\end{array}$ & Issue \\
\hline 39. & $9 / 6 / 74$ & $\mathrm{JH}$ & 102 & $\begin{array}{l}\text { Three seams were split on Tank } 102 \text { to correct } \\
\text { distortion. }\end{array}$ & Issue \\
\hline 40. & $9 / 10 / 74$ & $\mathrm{JH}$ & 103 & $\begin{array}{l}\text { Changed welding sequence on Tank } 103 \text { to } \\
\text { prevent distortion. NCR filed because of } \\
\text { procedural change. }\end{array}$ & Issue \\
\hline 41. & 9/13/74 & $\mathrm{JH}$ & 102 & One area was rejected Tank 102. & Issue \\
\hline 42. & $9 / 13 / 74$ & $\mathrm{JH}$ & 103 & $\begin{array}{l}\text { Two areas were rejected Tank } 103 \text { and one } \\
\text { required a re-shot. }\end{array}$ & Issue \\
\hline 43. & 9/16/74 & $\mathrm{JH}$ & 102 & $\begin{array}{l}\text { Five welds on Tank } 102 \text { were rejected and five re- } \\
\text { shots on other areas. }\end{array}$ & Issue \\
\hline
\end{tabular}


RPP-RPT-54819, Rev. 0

\begin{tabular}{|c|c|c|c|c|c|}
\hline No. & Date & $\begin{array}{l}\text { Initials of } \\
\text { Inspector }\end{array}$ & Tank & Comments & Event Type \\
\hline 44. & $9 / 17 / 74$ & $\mathrm{JH}$ & 102 & $\begin{array}{l}\text { Rejected four areas on Tank } 102 \text { and required on } \\
\text { re-shot. }\end{array}$ & Issue \\
\hline 45. & $9 / 18 / 74$ & $\mathrm{JH}$ & 102 & Three welds were rejected on Tank 102. & Issue \\
\hline 46. & 9/19/74 & RRT & 102 & Tank 102 lowered radiograph inspections in order, & Construction \\
\hline 47. & $9 / 19 / 74$ & $\mathrm{JH}$ & & Completed inspection of Tank 102. & Construction \\
\hline 48. & $9 / 19 / 74$ & $\mathrm{JH}$ & $\begin{array}{l}101 \\
\text { and } \\
103\end{array}$ & $\begin{array}{l}\text { Reviewed Tank } 101 \text { and } 103 \text { and rejected three } \\
\text { welds and required on re-shot. }\end{array}$ & Issue \\
\hline 49. & $9 / 19 / 74$ & $\mathrm{JH}$ & 102 & $\begin{array}{l}\text { Observed lowering of Tank } 102 \text { bottom. Lack of } \\
\text { control led up to 18” of distortion. A special } \\
\text { report was supposed to be written. }\end{array}$ & Issue \\
\hline 50. & $9 / 20 / 74$ & $\mathrm{JH}$ & $\begin{array}{l}101 \\
102, \\
\text { and } \\
103\end{array}$ & $\begin{array}{l}\text { Tank } 101 \text { and } 103 \text { two areas rejected and two } \\
\text { areas require re-shots. Tank } 102 \text { had 5/8’’ per } \\
\text { foot slope and a } 21 / 4 \text { ” high low delta. Vitro } \\
\text { inspected deflection in knuckle } 4 \text {-A-A damaged } \\
\text { the integrity of Tank } 102 \text {. }\end{array}$ & Issue \\
\hline 51. & $9 / 21 / 74$ & $\mathrm{JH}$ & 102 & $\begin{array}{l}\text { Wrote special report on the sequence of events } \\
\text { while lowering } 102 \text {. Don Mager wrote } 3 \text { non- } \\
\text { conformance reports. }\end{array}$ & Issue \\
\hline 52. & $9 / 23 / 74$ & $\mathrm{JH}$ & $\begin{array}{l}101 \\
\text { and } \\
103\end{array}$ & $\begin{array}{l}\text { Reviewed Tank } 101 \text { and } 103 . \text { Three areas were } \\
\text { rejected and } 17 \text { areas required re-shots. }\end{array}$ & Issue \\
\hline 53. & $9 / 24 / 74$ & JGCD & 102 & $\begin{array}{l}\text { Failed to cool tank bottom (102) with water below } \\
90^{\circ} \mathrm{F} \text { (went from } 114^{\circ} \mathrm{F} \text { to } 106{ }^{\circ} \mathrm{F} \text { ). Delayed } \\
\text { placement of Lite Wate } 50 \text { refractory till } \\
\text { tomorrow. }\end{array}$ & Issue \\
\hline 54. & $9 / 25 / 74$ & $\mathrm{JH}$ & $\begin{array}{l}101 \\
\text { and } \\
103\end{array}$ & $\begin{array}{l}\text { Reviewed Tank } 101 \text { and } 103 \text {. Eight areas were } \\
\text { rejected and three areas required re-shots. }\end{array}$ & Issue \\
\hline 55. & $9 / 25 / 74$ & JGCD & 102 & $\begin{array}{l}\text { Started placement of refractory in Tank } 102 \text { at } \\
\text { 5:30 a.m. delayed from 4:00 a.m. because of } \\
\text { mixer problems. Eight sections were poured by } \\
\text { 2:15 p.m. }\end{array}$ & Construction \\
\hline
\end{tabular}


RPP-RPT-54819, Rev. 0

\begin{tabular}{|c|c|c|c|c|c|}
\hline No. & Date & $\begin{array}{l}\text { Initials of } \\
\text { Inspector }\end{array}$ & Tank & Comments & Event Type \\
\hline 56. & $9 / 26 / 74$ & JGCD & 102 & $\begin{array}{l}\text { Started placement of the last four sections at } 7: 30 \\
\text { a.m. One of the machines broke down at } 8: 30 \\
\text { a.m. Machine repaired by noon. Cast completed } \\
\text { by 1:50 p.m. }\end{array}$ & Construction \\
\hline 57. & $9 / 27 / 74$ & JGCD & 102 & $\begin{array}{l}\text { Cleaned up of the refractory and started cutting } \\
\text { the V-shaped trenches on top of the slab. }\end{array}$ & Construction \\
\hline 58. & $9 / 30 / 74$ & JGCD & 102 & $\begin{array}{l}\text { Thompson Mechanical cut out trenches on top } \\
\text { light weight concrete. }\end{array}$ & Construction \\
\hline 59. & $9 / 30 / 74$ & JH & 101 & $\begin{array}{l}\text { Radiographs reviewed, Tank } 101 \text { lowered, and } \\
\text { P.T. examination of welds after lowering to point } \\
\text { where refractory could be poured. }\end{array}$ & Construction \\
\hline 60. & $9 / 30 / 74$ & JH & 102 & $\begin{array}{l}\text { Tank } 102 \text { design elevation is suppose to } 617.2^{\prime} \pm \\
1 / 4 \text { ". The maximum deviation was } 1 / 2 \text { " a NCR has } \\
\text { been written. }\end{array}$ & Issue \\
\hline 61. & $10 / 1 / 74$ & JH & $\begin{array}{l}101 \\
\text { and } \\
103\end{array}$ & $\begin{array}{l}\text { Rejected one area of Tank } 103 \text { secondary bottom. } \\
\text { Tank } 101 \text { bottom high low was } 31 / 8 \text { ”. Maximum } \\
\text { slope per foot was 13/16”. A NCR was written. }\end{array}$ & Issue \\
\hline 62. & $10 / 2 / 74$ & JGCD & 101 & $\begin{array}{l}\text { Delayed pouring Tank } 101 \text { because tank bottom } \\
\text { out of tolerance. }\end{array}$ & Issue \\
\hline 63. & $10 / 3 / 74$ & JGCD & 101 & $\begin{array}{l}\text { Tank } 101 \text { refractory placement delayed from 4:00 } \\
\text { a.m. to 7:30 a.m. Placed eight of twelve sections }\end{array}$ & Construction \\
\hline 64. & $10 / 4 / 74$ & JGCD & 101 & $\begin{array}{l}\text { Placed the remaining fours section in Tank } 101 . \\
\text { Started at 7:00 a.m., one of the two machines } \\
\text { broke down at } 8: 00 \text { a.m., repaired by noon, and } \\
\text { pour was completed by 1:00 p.m. Lowest } \\
\text { temperature was } 46^{\circ} \mathrm{F} \text { at } 6: 30 \text { a.m. }\end{array}$ & Construction \\
\hline 65. & $10 / 7 / 74$ & JGCD & 101 & Tank 101 air slots cut. & Construction \\
\hline 66. & $10 / 9 / 74$ & JGCD & $\begin{array}{l}101 \\
\text { and } \\
102\end{array}$ & $\begin{array}{l}\text { Thompson mechanical installed drain lines (sic) in } \\
\text { Tank } 101 \text { and } 102 .\end{array}$ & Construction \\
\hline 67. & $10 / 14 / 75$ & JMJ & $\begin{array}{l}101, \\
102 \\
\text { and } \\
103\end{array}$ & $\begin{array}{l}\text { Witnessed welding } 101 \text { and } 102 \text { primary bottom } \\
\text { and } 103 \text { secondary. }\end{array}$ & Construction \\
\hline 68. & $10 / 15 / 74$ & JGCD & $\begin{array}{l}101 \\
\text { and } \\
102\end{array}$ & $\begin{array}{l}\text { Thompson Mechanical poured lite weight } \\
\text { concrete over drain lines (sic) in Tank } 101 \text { and } \\
102 \text {. }\end{array}$ & Construction \\
\hline
\end{tabular}


RPP-RPT-54819, Rev. 0

\begin{tabular}{|c|c|c|c|c|c|}
\hline No. & Date & $\begin{array}{l}\text { Initials of } \\
\text { Inspector }\end{array}$ & Tank & Comments & Event Type \\
\hline 69. & $10 / 22 / 74$ & SLW & 102 & $\begin{array}{l}\text { Witnessed Lord Electric install heating grid } 102 \\
\text { tank bottom. Issue on how to attach to refractory } \\
\text { because tape didn't hold. Small hand driven } \\
\text { staples were used to prevent damage to heating } \\
\text { cable. Small samples removed from concrete } \\
\text { poured over vent pipes. No cylinders were } \\
\text { obtained because of boilermaker's strike. }\end{array}$ & Construction \\
\hline 70. & $10 / 24 / 74$ & SLW & $\begin{array}{l}101 \\
\text { and } \\
102\end{array}$ & $\begin{array}{l}\text { Heat grid completed Tank } 102 \text { one inch of sand } \\
\text { cover placed. Started placement of grid on } 101 \text {. } \\
\text { Temperature } 32^{\circ} \mathrm{F} \text {. }\end{array}$ & Construction \\
\hline 71. & $10 / 28 / 74$ & SLW & 101 & Heat grid completed for Tank 101. & Construction \\
\hline 72. & $10 / 29 / 74$ & SLW & $\begin{array}{l}101 \\
\text { and } \\
102\end{array}$ & $\begin{array}{l}\text { All power for Tank } 101 \text { and } 102 \text { heating grids on } \\
\text { at 4:00 p.m. }\end{array}$ & Construction \\
\hline 73. & $11 / 19 / 74$ & SLW & $\begin{array}{l}101 \\
\text { and } \\
102\end{array}$ & $\begin{array}{l}\text { Placed jack stands and leveled supports for Tank } \\
101 \text { and } 102 .\end{array}$ & Construction \\
\hline 74. & $11 / 20 / 74$ & SLW & 102 & $\begin{array}{l}\text { Primary tank placed } 102 \text {. One plate fell when } \\
\text { clamp came loose. Fell pointed end first, which } \\
\text { hit the ground. The other end hit the skirt to } \\
\text { secondary. No damage to skirt or plate. }\end{array}$ & Construction/Issue \\
\hline 75. & $11 / 25 / 74$ & SLW & 102 & Started walls on 102 secondary. & Construction \\
\hline 76. & $11 / 27 / 74$ & SLW & 101 & $\begin{array}{l}\text { Skirts being set in place on primary for } 101 \text {. } \\
\text { These welds were field welds unlike } 102 \text { where } \\
\text { they were shop welds. }\end{array}$ & Construction \\
\hline 77. & $12 / 5 / 74$ & SLW & 101 & $\begin{array}{l}\text { One area of excessive reinforcement about } 12 \\
\text { inches long on circumferential weld } 4 \text { AV knuckle } \\
\text { section. }\end{array}$ & Issue \\
\hline 78. & $12 / 9 / 74$ & SLW & 103 & $\begin{array}{l}\text { Started lowering Tank } 103 \text {. Left it on jacks at } \\
\text { 2:00 p.m. }\end{array}$ & Construction \\
\hline 79. & $12 / 10 / 74$ & SLW & 103 & $\begin{array}{l}\text { Finished Tank } 103 \text { lowering and conducted liquid } \\
\text { penetrant tests. }\end{array}$ & Construction \\
\hline 80. & $12 / 11 / 74$ & SLW & 103 & Finished liquid penetrant test. & Construction \\
\hline 81. & $12 / 12 / 74$ & SLW & 103 & $\begin{array}{l}\text { Tank } 103 \text { secondary liner inspected because high } \\
\text { areas exceeded 3/8” per foot specification. }\end{array}$ & Issue \\
\hline
\end{tabular}


RPP-RPT-54819, Rev. 0

\begin{tabular}{|c|c|c|c|c|c|}
\hline No. & Date & $\begin{array}{l}\text { Initials of } \\
\text { Inspector }\end{array}$ & Tank & Comments & Event Type \\
\hline 82. & $12 / 18 / 74$ & SLW & 103 & $\begin{array}{l}\text { Tank } 103 \text { air hammers were used against } \\
\text { planishing hammers to reduce the } 2 \text { high areas in } \\
\text { the secondary bottom (no change). Next } 6000 \\
\text { pound was placed on the humps and again air } \\
\text { hammers were used (no change). }\end{array}$ & Issue \\
\hline 83. & $12 / 19 / 74$ & SLW & 103 & $\begin{array}{l}\text { The high areas on the bottom of Tank } 103 \text { were } \\
\text { inspected using magnetic particle. There were no } \\
\text { questionable areas in the welds or plate material } \\
\text { itself. }\end{array}$ & Issue \\
\hline 84. & $1 / 15 / 75$ & JMJ & 101 & $\begin{array}{l}\text { Tank } 101 \text { primary bottom witnessed dye check } \\
\text { and weld repair cycles on several seams. In many } \\
\text { cases, more than one repair necessary. Two caps } \\
\text { missing from conduit. }\end{array}$ & Issue \\
\hline 85. & $1 / 14 / 75$ & JMJ & 103 & $\begin{array}{l}\text { Request to cut access hole in secondary liner } \\
\text { issued to AEC for approval. }\end{array}$ & Construction \\
\hline 86. & $1 / 23 / 75$ & JMJ & $\begin{array}{l}101 \\
\text { and } \\
102\end{array}$ & $\begin{array}{l}\text { Tank } 101 \text { primary bottom cut out North/South } \\
\text { short weld due to humping. Additional strong } \\
\text { backs were installed prior to re-welding. } \\
\text { Tank } 102 \text { primary bottom slightly out of } \\
\text { specification 9/16” per foot. Decided to lower } \\
\text { tank and see whether it was alleviated. }\end{array}$ & Issue \\
\hline 87. & $1 / 24 / 75$ & $\mathrm{JMJ}$ & $\begin{array}{l}101 \\
\text { and } \\
102\end{array}$ & $\begin{array}{l}\text { Tank } 101 \text { primary bottom North/South short weld } \\
\text { replaced. Tank } 102 \text { all pick-ups have been fixed. } \\
\text { All welds on Tank } 102 \text { up to knuckle skirt visually } \\
\text { inspected and found acceptable. }\end{array}$ & Issue \\
\hline 88. & $1 / 27 / 75$ & JMJ & & $\begin{array}{l}\text { Considerable time lost because hoses frozen to } \\
\text { tank bottoms. Contractor attempting to reduce } \\
\text { standing water in the tanks to minimize the } \\
\text { problem in the future. }\end{array}$ & Issue \\
\hline 89. & $1 / 30 / 75$ & JMS & $\begin{array}{l}101 \\
\text { and } \\
103\end{array}$ & $\begin{array}{l}\text { Tank } 101 \text { and } 103 \text { had shop splice seam a } \\
\text { designed three plate weld junction. This created a } \\
\text { four plate weld junction, which violated B-101-C1 } \\
\text { pp. C-13. }\end{array}$ & Issue \\
\hline 90. & $2 / 4 / 75$ & $J M J$ & & Blizzard in progress. & N/A \\
\hline 91. & $2 / 5 / 75$ & JMJ & & $\begin{array}{l}\text { Contractor spent most of the morning removing } \\
\text { snow from all three tanks. }\end{array}$ & Issue \\
\hline 92. & $2 / 7 / 75$ & JMJ & 102 & $\begin{array}{l}\text { Tank } 102 \text { cracking in refractory around twelve } \\
\text { cribbing supports. Thompson to repair only really } \\
\text { bad spots over the weekend. }\end{array}$ & Issue \\
\hline
\end{tabular}


RPP-RPT-54819, Rev. 0

\begin{tabular}{|c|c|c|c|c|c|}
\hline No. & Date & $\begin{array}{l}\text { Initials of } \\
\text { Inspector }\end{array}$ & Tank & Comments & Event Type \\
\hline 93. & $2 / 8 / 75$ & JD & 102 & $\begin{array}{l}\text { Repaired Kaolite in Tank } 102 \text { area about } \\
\text { 8'x5'x2”. It was chipped out to } 21 \frac{1 / 2}{2} \text {.. Concrete } \\
\text { mixed by hand placed at } 65^{\circ} \mathrm{F} \text {. }\end{array}$ & Issue \\
\hline 94. & $2 / 10 / 75$ & JCGD & 102 & Inspected the Kaolite repair. It looked very good. & Issue \\
\hline 95. & 2/10/75 & JMJ & 102 & $\begin{array}{l}\text { Frost on refractory of Tank } 102\left(30^{\circ} \mathrm{F}\right) \text {. It passed } \\
\text { hammer test. Began lowering primary bottom at } \\
\text { 2:00 p.m. Lowered one foot by end of shift. It } \\
\text { was swiveling and had } 5 / 8^{\prime \prime} \text { deflection. }\end{array}$ & Issue \\
\hline 96. & 2/11/75 & JMJ & $\begin{array}{l}101 \\
\text { and } \\
102\end{array}$ & $\begin{array}{l}\text { Strong backs removed for Tank } 101 \text {. Bottom was } \\
\text { out of level in several places. Contractor } \\
\text { evaluated which welds to cut out to make } \\
\text { corrections. } \\
\text { Tank } 102 \text { was lowered. Thermocouple (TE-102- } \\
\text { 1) was caught between the tank and refractory. } \\
\text { Tank was raised and it was slid into to its slot. }\end{array}$ & Issue \\
\hline 97. & $2 / 14 / 75$ & JMJ & 101 & $\begin{array}{l}\text { Removing } 3 \text { to } 4 \text { foot of weld near peak of } \\
\text { distortion. }\end{array}$ & Issue \\
\hline 98. & 2/19/75 & JMJ & 101 & $\begin{array}{l}\text { Tank } 101 \text { removing plywood, insulation, and sand } \\
\text { from insulating concrete. Space heater installed. } \\
\text { Too wet to continue mag particle inspection. }\end{array}$ & Construction \\
\hline 99. & $2 / 21 / 75$ & JMJ & 101 & $\begin{array}{l}\text { Completed mag particle and visual inspection of } \\
\text { primary bottom. }\end{array}$ & Construction \\
\hline 100. & $2 / 24 / 75$ & JMJ & 102 & $\begin{array}{l}\text { Tank } 102 \text { secondary circumference out of } \\
\text { specification. Required to } 251^{\prime} 69 / 32 \text { ” } \pm 2 \text { ”. It } \\
\text { was } 251 \text { ' } 33 / 8 \text { ” } 6 \text { inches above the bottom of the } \\
1^{\text {st }} \text { course shell plate and } 251 \text { ' } 278 \text { " } 6 \text { inches } \\
\text { about the bottom of } 2^{\text {nd }} \text { course shell plate. } \\
\text { Condition "accepted as is” in NCR B-101-29- } \\
2307-14 \text {. }\end{array}$ & Issue \\
\hline 101. & 2/25/75 & JMJ & & Dome plating sub-assemblies being welded. & Construction \\
\hline 102. & $2 / 26 / 75$ & JMJ & 101 & Tank 101 thermocouples being installed. & Construction \\
\hline 103. & 2/27/75 & JMJ & 101 & $\begin{array}{l}\text { Completed lowering check list and start lowering } \\
\text { tank at 1:40 p.m. }\end{array}$ & Construction \\
\hline 104. & 2/28/75 & JMJ & 101 & $\begin{array}{l}\text { Lowered Tank } 101 \text { primary bottom. Four inches } \\
\text { in the air and center, but tank had swiveled about } \\
11 / 4 \text { " in counter clockwise direction. Come along } \\
\text { installed and correction attempted and corrected. }\end{array}$ & Construction \\
\hline
\end{tabular}


RPP-RPT-54819, Rev. 0

\begin{tabular}{|c|c|c|c|c|c|}
\hline No. & Date & $\begin{array}{l}\text { Initials of } \\
\text { Inspector }\end{array}$ & Tank & Comments & Event Type \\
\hline 105. & $3 / 3 / 75$ & JMJ & 101 & $\begin{array}{l}\text { Tank } 101 \text { completed lowering operation and } \\
\text { began post-placement penetrant testing. }\end{array}$ & Construction \\
\hline 106. & $3 / 4 / 75$ & JMJ & 101 & Tank 101 primary completed penetrant testing. & Construction \\
\hline 107. & $3 / 5 / 75$ & JMJ & 101 & $\begin{array}{l}\text { Tank } 101 \text { installed insulating boards and plywood } \\
\text { for protection. }\end{array}$ & Construction \\
\hline 108. & $3 / 8 / 75$ & JGCD & 103 & $\begin{array}{l}\text { Started pumping refractory at 9:05 a.m. and } \\
\text { finished at 3:00 p.m. It went well with no break } \\
\text { downs. Completed four sections of twelve. }\end{array}$ & Construction \\
\hline 109. & $3 / 9 / 75$ & JGCD & 103 & $\begin{array}{l}\text { Started placing concrete at } 7: 55 \text { a.m., blew a } \\
\text { piston gasket at 1:10 p.m., wheeled in stand-by } \\
\text { pump, started pumping with it, shutdown stand-by } \\
\text { after two baskets, and completed pour with one } \\
\text { pump at 2:00 p.m. }\end{array}$ & Construction \\
\hline 110. & $3 / 10 / 75$ & JMJ & 101 & $\begin{array}{l}\text { Visually inspected Tank } 101 \text { secondary shell and } \\
\text { found numerous instances of poor workmanship. } \\
\text { Protest filed because the sub-contractor is suppose } \\
\text { to perform the visual inspection. }\end{array}$ & Issue \\
\hline 111. & $3 / 10 / 75$ & JMJ & 102 & $\begin{array}{l}\text { Tank } 102 \text { secondary stud welding and fillet } \\
\text { welding on stiffener ring in progress. }\end{array}$ & Construction \\
\hline 112. & $3 / 10 / 75$ & JMJ & 103 & $\begin{array}{l}\text { Tank } 103 \text { refractory was poured over the } \\
\text { weekend. Air slots being cut. }\end{array}$ & Construction \\
\hline 113. & $3 / 11 / 75$ & JMJ & 101 & Tank 101 secondary installing $1^{\text {st }}$ stiffener ring. & Construction \\
\hline 114. & $3 / 14 / 75$ & JMJ & 103 & Tank 103 secondary installing $1^{\text {st }}$ stiffener ring. & Construction \\
\hline 115. & $3 / 18 / 75$ & JMJ & $\begin{array}{l}101 \\
\text { and } \\
103\end{array}$ & $\begin{array}{l}\text { Tank } 101 \text { insulating concrete was pumped into } \\
\text { tank refractory in the two damaged areas, which } \\
\text { had been chipped out. Tank } 103 \text { was poured in } \\
\text { the twelve cribbing stacks that had interfered with } \\
\text { the original pour. }\end{array}$ & Construction/Issue \\
\hline 116. & $3 / 21 / 75$ & JMJ & 102 & $\begin{array}{l}\text { Tank } 102 \text { primary second shell ring show it to be } \\
\text { out-of-round. The difference between the } \\
\text { maximum and minimum diameters was } 63 / 8 \text { ” } \\
\text { exceeding the allowable } 41 / 2 \text { ”. Guy wire installed. } \\
\text { Next ring can't be placed until correction is made. }\end{array}$ & Issue \\
\hline 117. & $3 / 25 / 75$ & JMJ & 102 & $\begin{array}{l}\text { Contractor used } 3 \text { guy wires to bring } 2^{\text {nd }} \text { shell ring } \\
\text { back into tolerance }\end{array}$ & Issue \\
\hline 118. & 3/26/75 & JMJ & 102 & Diameter deviation on $2^{\text {nd }}$ shell ring down to $3 \frac{1}{1} 2$ & Issue \\
\hline
\end{tabular}


RPP-RPT-54819, Rev. 0

\begin{tabular}{|c|c|c|c|c|c|}
\hline No. & Date & $\begin{array}{l}\text { Initials of } \\
\text { Inspector }\end{array}$ & Tank & Comments & Event Type \\
\hline & & & & $\begin{array}{l}\text { inches by use of temporary attachments, they will } \\
\text { be released when the } 2-3 \text { girth seam is welded }\end{array}$ & \\
\hline 119. & $4 / 2 / 75$ & JMJ & 101 & $\begin{array}{l}\text { Tank } 101 \text { primary second shell ring is measured } \\
\text { and shown to be out of round. Deviation is } 61 / 2 \\
\text { inch while specified maximum is } 41 / 2 \text { inch. Will } \\
\text { correct with guy wires before welding } 2-3 \text { girth } \\
\text { seam. }\end{array}$ & Issue \\
\hline 120. & $4 / 15 / 75$ & JMJ & & All dome sub-assemblies welded. & Construction \\
\hline 121. & $5 / 8 / 75$ & JMJ & 102 & $\begin{array}{l}\text { Problems continued with attempting to lift dome } \\
\text { plate because it droops too much so that the } \\
\text { contractor can't correctly place it. }\end{array}$ & Issue \\
\hline 122. & $5 / 12 / 75$ & JGCD & 102 & $\begin{array}{l}\text { Tank } 102 \text { placing vertical steel some with spacing } \\
\text { of } 15 \text { ”. Corrected. }\end{array}$ & Issue \\
\hline 123. & $5 / 16 / 75$ & JGCD & 102 & $\begin{array}{l}\text { Starting pouring concrete of first lift on Tank } 102 \text {. } \\
\text { First truck sent away after placement of } 2 \text { cubic } \\
\text { yards because it was too dry. Truck had about } \\
\text { four yards left in it. The truck had been loaded } \\
\text { with a 7-bag mix about an hour and } 15 \text { minutes } \\
\text { prior to delivery. Pouring started at } 8: 30 \text { a.m. and } \\
\text { stopped at 5:15 p.m. with a total of } 150 \text { cubic } \\
\text { yards being poured. }\end{array}$ & Issue \\
\hline 124. & $5 / 21 / 75$ & JGCD & 101 & $\begin{array}{l}\text { Tank } 101 \text { concrete was poured for the first lift } \\
\text { between } 8: 15 \text { a.m. and 1:10 p.m. The pour was } \\
\text { good with no cold joints. }\end{array}$ & Construction \\
\hline 125. & $5 / 28 / 75$ & JGCD & 102 & $\begin{array}{l}\text { Concrete was placed in the upper walls of Tank } \\
102 \text { between 7:45 a.m. and 3:10 p.m. Went good } \\
\text { no cold joints. }\end{array}$ & Construction \\
\hline 126. & $6 / 2 / 75$ & JGCD & 102 & $\begin{array}{l}\text { First lift on Tank } 103 \text { poured between 8:00 a.m. } \\
\text { and 12:15 p.m. Placement was very good. }\end{array}$ & Construction \\
\hline 127. & $6 / 4 / 75$ & JGCD & 102 & $\begin{array}{l}\text { Pour walls on Tank } 101 \text { started at 6:00 a.m. and } \\
\text { completed at 2:10 p.m. }\end{array}$ & Construction \\
\hline 128. & $6 / 6 / 75$ & DDB & $\begin{array}{l}101 \\
\text { and } \\
103\end{array}$ & $\begin{array}{l}\text { Tank } 101 \text { and } 103 \text { mag particle where } \\
\text { attachments were removed. }\end{array}$ & Construction \\
\hline 129. & $6 / 12 / 75$ & DDB & 101 & $\begin{array}{l}\text { Studs bend and torque tested on Tank } 101 \text { to } 130 \\
\text { foot pounds on a test plate. Plate dropped on } \\
\text { steam line. Plate was examined and showed no } \\
\text { appreciable damage and it was used. }\end{array}$ & Issue \\
\hline
\end{tabular}


RPP-RPT-54819, Rev. 0

\begin{tabular}{|c|c|c|c|c|c|}
\hline No. & Date & $\begin{array}{l}\text { Initials of } \\
\text { Inspector }\end{array}$ & Tank & Comments & Event Type \\
\hline 130. & $6 / 21 / 75$ & ? & 102 & $\begin{array}{l}\text { Start up at } 3: 00 \text { p.m. At } 5: 00 \text { p.m. all burners } \\
\text { operating at } 1 / 6^{\text {th }} \text { potential capacity. Flame } \\
\text { viewed at } 5: 00 \text { p.m. about } 5 \text { feet in length. }\end{array}$ & Construction \\
\hline 131. & $6 / 21 / 75$ & JMJ & 102 & Turned on four burners on Tank 102 at 5:00 p.m. & Construction \\
\hline 132. & $6 / 22 / 75$ & DB & 102 & $\begin{array}{l}\text { As many as } 13 \text { thermocouples taken out service. } \\
12 \text { may have returned after steam dry out. }\end{array}$ & Issue \\
\hline 133. & $6 / 23 / 75$ & JMJ & 102 & $\begin{array}{l}\text { At } 3: 30 \text { p.m. the contractor still in process of } \\
\text { baking out steam from the insulating concrete. }\end{array}$ & Issue \\
\hline 134. & $6 / 23 / 75$ & DK & 102 & $\begin{array}{l}\text { All four burners out at 2:00 a.m. Relit by 2:12 } \\
\text { a.m. }\end{array}$ & Issue \\
\hline 135. & $6 / 23 / 75$ & DK & 102 & $\begin{array}{l}\text { At } 10: 42 \text { a.m. contractor began official hold time } \\
\text { and was terminated at 11:42 a.m. At } 12: 30 \text { p.m. } \\
\text { temperatures were dropping at } 60^{\circ} \mathrm{F} \text { per hour. } \\
\text { Maximum foundation concrete temperature } \\
\text { recorded was } 170^{\circ} \mathrm{F} \text {, which was below } 500^{\circ} \mathrm{F} \\
\text { allowed. }\end{array}$ & Construction \\
\hline 136. & $6 / 24 / 75$ & JMJ & 102 & $\begin{array}{l}\text { Recorders turned off on Tank } 102 \text { at } 7: 30 \text { p.m. } \\
\text { Noted problems with thermocouples under } \\
\text { primary tank due shorting. }\end{array}$ & Construction \\
\hline 137. & $6 / 26 / 75$ & JMJ & $\begin{array}{l}101 \\
\text { and } \\
102\end{array}$ & $\begin{array}{l}\text { Erected leak detection riser for Tank } 101 \text {. Tank } \\
102 \text { dollar plate welded and ready for installation. }\end{array}$ & Construction \\
\hline 138. & $6 / 30 / 75$ & DDB & 103 & Tank 103 radiation detection pit riser erected. & Construction \\
\hline 139. & $7 / 2 / 75$ & DDB & 102 & $\begin{array}{l}\text { Penetrant testing completed on Tank } 102 \text {. Started } \\
\text { cleanup of excavation to support backfill. }\end{array}$ & Construction \\
\hline 140. & $7 / 3 / 75$ & DDB & All & $\begin{array}{l}\text { Completed cleanup of excavation for backfill at } \\
\text { 11:30 a.m. and CBI went home. }\end{array}$ & Construction \\
\hline 141. & $7 / 4 / 75$ & JGCD & 102 & $\begin{array}{l}\text { Began rolling the back fill with a D- } 4 \text { Caterpillar. } \\
\text { Scrapper got stuck on three conduits on the South } \\
\text { side Tank } 102 \text {. Bent two and flatten one. Two } \\
\text { straighten out and third replaced. }\end{array}$ & Issue \\
\hline 142. & $7 / 7 / 75$ & DDB & 102 & Dollar plate being welded into Tank 102. & Construction \\
\hline 143. & $7 / 9 / 75$ & DDB & $\begin{array}{l}101 \\
102 \\
\text { and } \\
103\end{array}$ & $\begin{array}{l}\text { Tank } 101 \text { ready to hook all of the thermocouple } \\
\text { wires. } \\
\text { Tank } 102 \text { is being filled with water for hydrostatic } \\
\text { test. Welding of the roof dollar plate completed. }\end{array}$ & Construction \\
\hline
\end{tabular}


RPP-RPT-54819, Rev. 0

\begin{tabular}{|c|c|c|c|c|c|}
\hline No. & Date & $\begin{array}{l}\text { Initials of } \\
\text { Inspector }\end{array}$ & Tank & Comments & Event Type \\
\hline & & & & Tank 103 ready for insulation. & \\
\hline 144. & $7 / 10 / 75$ & SLW & 101 & Turned on four burners in Tank 101 at 2:00 p.m. & Construction \\
\hline 145. & $7 / 10 / 75$ & DDB & 102 & Tank 102 filling for Hydro test. & Construction \\
\hline 146. & 7/11/75 & DK & 101 & $\begin{array}{l}\text { Completed two hour hold time at } 600^{\circ} \mathrm{F} \text { hold time } \\
\text { at 5:30 a.m. }\end{array}$ & Construction \\
\hline 147. & $7 / 12 / 75$ & DBK & 101 & $\begin{array}{l}\text { At } 12: 10 \text { a.m. three hour hold time for } 1000^{\circ} \mathrm{F} \\
\text { was met. CBI started down at } 100^{\circ} \mathrm{F} \text { at a time } \\
\text { from } 1000^{\circ} \mathrm{F} \text { requirement. At } 8: 10 \text { a.m. all } \\
\text { recorder below } 600^{\circ} \mathrm{F} \text { and recorders turned off. }\end{array}$ & Construction \\
\hline 148. & $7 / 12 / 75$ & JMJ & 101 & $\begin{array}{l}\text { At 8:10 a.m. all recorders below } 600^{\circ} \mathrm{F} \text { and turn } \\
\text { off. }\end{array}$ & Construction \\
\hline 149. & $7 / 15 / 75$ & DDB & 101 & Started penetrant test Tank 101. & Construction \\
\hline 150. & $7 / 21 / 75$ & DDB & 102 & $\begin{array}{l}\text { Tank } 102 \text { fittings on roof dollar plate are being } \\
\text { erected. Secondary knuckles are being fitted too. }\end{array}$ & Construction \\
\hline 151. & $7 / 22 / 75$ & DDB & 101 & Tank 101 dollar plate being welded. & Construction \\
\hline 152. & $7 / 24 / 75$ & DDB & 101 & $\begin{array}{l}\text { Tank } 101 \text { all seams below } 39 \text { feet of water have } \\
\text { been coated with blue chalk for hydro test. }\end{array}$ & Construction \\
\hline 153. & $7 / 25 / 75$ & EAG & 102 & $\begin{array}{l}\text { Investigated Tank } 102 \text { insulating concrete around } \\
\text { tank perimeter after stress relief. Found three } \\
\text { notable areas deterioration. About half of the } \\
\text { perimeter had friable area about } 1 / 8 \text { ” thick at the } \\
\text { perimeter. }\end{array}$ & Issue \\
\hline 154. & $7 / 25 / 75$ & DDB & 101 & Completed hydrostatic test of Tank 101. & Construction \\
\hline 155. & $7 / 29 / 75$ & DDB & 101 & $\begin{array}{l}\text { Tank } 101 \text { fit up and welding of upper secondary } \\
\text { knuckle. }\end{array}$ & Construction \\
\hline 156. & $8 / 1 / 75$ & DB & 103 & $\begin{array}{l}\text { Tank } 103 \text { stress relieving start at 10:00 a.m. } \\
\text { Insulating concrete cure completed at 10:00 p.m. } \\
\text { and rise toward stress relieve temperature } \\
\text { initiated. }\end{array}$ & Construction \\
\hline 157. & $8 / 2 / 75$ & SLW & & $\begin{array}{l}\text { End of } 1100^{\circ} \mathrm{F} \text { hold at } 3: 00 \text { p.m. Vertical growth } \\
\text { of tank was } 31 / 2 \text { ” from ambient to } 1100^{\circ} \mathrm{F} \text {. At } \\
\text { 11:20 p.m., last thermocouple passed below } 600 \\
{ }^{\circ} \mathrm{F} \text {. }\end{array}$ & Construction \\
\hline 158. & $8 / 4 / 75$ & DB & 102 & Tank 102 final inspection of annulus space to & Construction \\
\hline
\end{tabular}


RPP-RPT-54819, Rev. 0

\begin{tabular}{|c|c|c|c|c|c|}
\hline No. & Date & $\begin{array}{l}\text { Initials of } \\
\text { Inspector }\end{array}$ & Tank & Comments & Event Type \\
\hline & & & & $\begin{array}{l}\text { facilitate erection of the make-up sheet on the } \\
\text { upper secondary knuckle. }\end{array}$ & \\
\hline 159. & $8 / 5 / 75$ & JMJ & 103 & $\begin{array}{l}\text { Tank } 103 \text { bottom re-surveyed to compare with } \\
\text { pre-stress relieved measurements. Inspector } \\
\text { observed little change in the area greatest } \\
\text { humping. }\end{array}$ & Issue \\
\hline 160. & $8 / 5 / 75$ & JGCD & 102 & Tank 102 rebar was being placed. & Construction \\
\hline 161. & $8 / 5 / 75$ & DB & 102 & Tank 102 make-up sheet welded. & Construction \\
\hline 162. & $8 / 6 / 75$ & JGCD & 102 & $\begin{array}{l}\text { Tank } 102 \text { cleaned key way and placed reinforcing } \\
\text { steel. }\end{array}$ & Construction \\
\hline 163. & $8 / 6 / 75$ & DB & 103 & Tank 103 passed penetrant test for bottom plates. & Construction \\
\hline 164. & $8 / 7 / 75$ & DB & 103 & $\begin{array}{l}\text { Tank } 103 \text { strained gauges were installed to get } \\
\text { readings prior to water be introduced. }\end{array}$ & Construction \\
\hline 165. & $8 / 7 / 75$ & RAN & 103 & $\begin{array}{l}\text { Inspected } 12 \text { strain gauges on Tank 103. Installed } \\
\text { per manufacture (Microdot) manual. Gauge \#3 } \\
\text { broke from extension and couldn't be used. No } \\
\text { tank load data was taken between 11:30 a.m. and } \\
\text { 12:30 p.m. }\end{array}$ & Construction \\
\hline 166. & $8 / 8 / 75$ & DB & $\begin{array}{l}101, \\
102 \\
\text { and } \\
103\end{array}$ & $\begin{array}{l}\text { Tank } 101 \text { final annulus inspection, which allowed } \\
\text { closing of the annulus space. } \\
\text { Tank } 102 \text { inspection construction joint for proper } \\
\text { depth and continuous length. } \\
\text { Tank } 103 \text { assisted in taking strain gauge } \\
\text { measurements at } 15 \text { feet } 3 \text { inches. }\end{array}$ & Construction \\
\hline 167. & $8 / 8 / 75$ & AWA & 102 & $\begin{array}{l}\text { Tank } 102 \text { Phase IV contractor (Moen) worried } \\
\text { that the Phase III contractor (CB\&I) didn’t follow } \\
\text { procedure for dome support. }\end{array}$ & Issue \\
\hline 168. & $8 / 11 / 75$ & DB & $\begin{array}{l}101 \\
\text { and } \\
103\end{array}$ & $\begin{array}{l}\text { Tank } 101 \text { make-up plate was welded in place. } \\
\text { Tank } 103 \text { hydrostatic test completed. }\end{array}$ & Construction \\
\hline 169. & 8/11/75 & JMJ & & $\begin{array}{l}\text { Received confirmation from design (E.A. } \\
\text { Gonkey) that minor deviations from design in } \\
\text { secondary top knuckle section pose no structural } \\
\text { problem. }\end{array}$ & Issue \\
\hline 170. & $8 / 11 / 75$ & FMS & 103 & $\begin{array}{l}\text { Unstable strain gauge readings at } 39 \text { foot water } \\
\text { level made it unpractical to obtain useful }\end{array}$ & Issue \\
\hline
\end{tabular}


RPP-RPT-54819, Rev. 0

\begin{tabular}{|c|c|c|c|c|c|}
\hline No. & Date & $\begin{array}{l}\text { Initials of } \\
\text { Inspector }\end{array}$ & Tank & Comments & Event Type \\
\hline & & & & information. & \\
\hline 171. & 8/11/75 & AWA & 102 & $\begin{array}{l}\text { Tank } 102 \text { CB\&I installed two riser caps and } \\
\text { brought water to the desired level. }\end{array}$ & Issue \\
\hline 172. & $8 / 12 / 75$ & DB & 103 & $\begin{array}{l}\text { Tank } 103 \text { welded three secondary knuckle plates } \\
\text { satisfactory. }\end{array}$ & Construction \\
\hline 173. & $8 / 12 / 75$ & FMS & 103 & $\begin{array}{l}\text { Used another instrument to obtain stress reading, } \\
\text { which didn't work either. }\end{array}$ & Issue \\
\hline 174. & 8/13/75 & DB & 101 & $\begin{array}{l}\text { Tank } 101 \text { cleared for rebar placement after } \\
\text { inspection of upper knuckle plates. }\end{array}$ & Construction \\
\hline 175. & $8 / 14 / 75$ & FMS & 103 & $\begin{array}{l}\text { Unsuccessful obtaining data with three-wire } \\
\text { connections to gauges. }\end{array}$ & Issue \\
\hline 176. & $8 / 15 / 75$ & FMS & & $\begin{array}{l}\text { Tried low resistance setting and continued to have } \\
\text { trouble reading a balanced condition. No further } \\
\text { effort was expended. }\end{array}$ & Issue \\
\hline 177. & $8 / 14 / 75$ & DB & 103 & $\begin{array}{l}\text { Tank } 103 \text { upper knuckle secondary plates being } \\
\text { welded. }\end{array}$ & Construction \\
\hline 178. & 8/14/75 & JGCD & 102 & $\begin{array}{l}\text { Tank } 102 \text { rebar is being placed and cadwelded. } \\
\text { Placed } 1 \frac{1 / 2 ”}{2} \text { plate on the West } 24 ” \text { Riser. }\end{array}$ & Construction \\
\hline 179. & 8/15/75 & JGCD & $\begin{array}{l}101 \\
\text { and } \\
102\end{array}$ & $\begin{array}{l}\text { Tank } 101 \text { chipping out key way. } \\
\text { Tank } 102 \text { continued placing and cadwelding rebar. } \\
\text { Placed plate around East } 24 \text { ” Riser. Placing J } \\
\text { bolts. }\end{array}$ & Construction \\
\hline 180. & 8/20/75 & AWA & 102 & $\begin{array}{l}\text { ARCHO and CB\&I expressed concern about } \\
\text { material placed on dome. Tank } 102 \text { was reviewed } \\
\text { and deemed satisfactory. Stressed to contractors } \\
\text { to keep stacks to a minimum. }\end{array}$ & Issue \\
\hline 181. & $8 / 20 / 75$ & DB & 103 & $\begin{array}{l}\text { Tank } 103 \text { checked the cleanliness of annulus. } \\
\text { Make-up plate welded into place. }\end{array}$ & Construction \\
\hline 182. & $8 / 21 / 75$ & DB & 103 & $\begin{array}{l}\text { Tank } 103 \text { inspected secondary upper haunch and } \\
\text { noted areas needing repair. }\end{array}$ & Issue \\
\hline 183. & $8 / 22 / 75$ & DB & 103 & $\begin{array}{l}\text { Tank } 103 \text { accepted repairs and visually accepted } \\
\text { the tank. Check that all plugs were installed in air } \\
\text { intakes. }\end{array}$ & Issue \\
\hline 184. & 8/26/75 & JGCD & 103 & Tank 103 chipping out key way. & Construction \\
\hline
\end{tabular}


RPP-RPT-54819, Rev. 0

\begin{tabular}{|c|c|c|c|c|c|}
\hline No. & Date & $\begin{array}{l}\text { Initials of } \\
\text { Inspector }\end{array}$ & Tank & Comments & Event Type \\
\hline 185. & $8 / 28 / 75$ & JGCD & $\begin{array}{l}101 \\
\text { and } \\
102\end{array}$ & $\begin{array}{l}\text { Rebar being placed on Tanks } 101 \text { and } 102 . \\
\text { Carpenter installing bulkhead 9’-0” in from } \\
\text { vertical wall. }\end{array}$ & Construction \\
\hline 186. & $8 / 28 / 75$ & JGCD & 102 & $\begin{array}{l}\text { Tank } 102 \text { center horizontal rebar were placed too } \\
\text { close to the outside wall. In the majority of } \\
\text { locations, the configuration won't allow } 51 \frac{12}{2} \text { OD } \\
\text { pumpcrete lines to enter for pumping concrete. }\end{array}$ & Issue \\
\hline 187. & $8 / 29 / 75$ & AWA & 102 & $\begin{array}{l}\text { Investigated misplacement of rebar in Tank } 102 . \\
\text { An NCR will occur. }\end{array}$ & Issue \\
\hline 188. & $9 / 18 / 75$ & AWA & 103 & $\begin{array}{l}\text { Tank } 103 \text { at 5:30 a.m. pumps shut off liquid level } \\
20 \text { feet. Battelle started taking strain gauge } \\
\text { measurements at 9:30 a.m. Readings were } \\
\text { finished at noon and pumps were re-started. }\end{array}$ & Issue \\
\hline 189. & $9 / 24 / 75$ & RAN & 103 & Tank 103 thirteen new strain gauges installed. & Issue \\
\hline 190. & $9 / 26 / 75$ & RL & 103 & $\begin{array}{l}\text { Instrument checked out and calibration completed. } \\
\text { Fill started at } 1715 \text { and turned off at } 1814 \text { water } \\
\text { level } 1 \text { ' 3’. Water turned on at } 1910 \text {. }\end{array}$ & Issue \\
\hline 191. & $9 / 27 / 75$ & RL & 103 & $\begin{array}{l}\text { Water off at 8:00 a.m. for data inside completed. } \\
\text { Enter annulus a 9:00 a.m. to inspect it. Completed } \\
\text { inspection at 10:30 a.m. water on at 10:40 a.m. }\end{array}$ & Issue \\
\hline 192. & $9 / 28 / 75$ & RL & 103 & $\begin{array}{l}\text { Water off at 4:00 a.m. at request of Exxon too } \\
\text { much noise for data. Data collected at 10:00 a.m. } \\
\text { Water turned on at 10:15 a.m. }\end{array}$ & Issue \\
\hline 193. & $10 / 1 / 75$ & JGCD & 102 & $\begin{array}{l}\text { Tank } 102 \text { workers cleaned and blew forms. } \\
\text { Carpenters placed key way at top of the pour. }\end{array}$ & Construction \\
\hline 194. & $10 / 2 / 75$ & JGCD & 102 & Tank 102 checked out forms. & Construction \\
\hline 195. & $10 / 3 / 75$ & JGCD & 102 & $\begin{array}{l}\text { Tank } 102 \text { poured } 400 \text { cubic yards of concrete for } \\
\text { the haunch. Fifteen cylinders taken } 3 \text { for } 4 \text {-day, } 6 \\
\text { for } 7 \text {-day, and } 6 \text { for } 28 \text {-day breaks. }\end{array}$ & Construction \\
\hline 196. & $10 / 6 / 75$ & JGCD & $\begin{array}{l}101 \\
\text { and } \\
102\end{array}$ & $\begin{array}{l}\text { Tank } 101 \text { placed bulk head. } \\
\text { Tank } 102 \text { stripped forms from concrete and } \\
\text { applied curing compound. }\end{array}$ & Construction \\
\hline 197. & $10 / 10 / 75$ & JGCD/JMJ & 102 & Tank 102 concrete was placed on the dome. & Construction \\
\hline 198. & $10 / 13 / 75$ & JGCD & 101 & $\begin{array}{l}\text { Tank } 101 \text { concrete placement started 7:15 a.m. } \\
\text { and finished at 9:15 p.m. Three inch pump broke } \\
\text { down used four inch pump until it was repaired. }\end{array}$ & Construction \\
\hline
\end{tabular}


RPP-RPT-54819, Rev. 0

\begin{tabular}{|c|c|c|c|c|c|}
\hline No. & Date & $\begin{array}{l}\text { Initials of } \\
\text { Inspector }\end{array}$ & Tank & Comments & Event Type \\
\hline 199. & $10 / 14 / 75$ & JGCD & $\begin{array}{l}101 \\
\text { and } \\
103\end{array}$ & $\begin{array}{l}\text { Tank } 101 \text { removed the bulk head. } \\
\text { Tank } 103 \text { installed rebar. }\end{array}$ & Construction \\
\hline 200. & $10 / 15 / 75$ & JGCD & 101 & $\begin{array}{l}\text { Tank } 101 \text { removed forms from section where } \\
\text { pump broke down. No signs of cold joints. }\end{array}$ & Issue \\
\hline 201. & $10 / 16 / 75$ & JMJ & 103 & $\begin{array}{l}\text { Tank } 103 \text { recalled radiographs to compare with } \\
\text { acoustic emission data. }\end{array}$ & Issue \\
\hline 202. & $10 / 20 / 75$ & & 103 & $\begin{array}{l}\text { Compare radiographs to Exxon's acoustic } \\
\text { emission testing. A report is forthcoming. }\end{array}$ & Issue \\
\hline 203. & 10/20/75 & JGCD & 101 & $\begin{array}{l}\text { Tank } 101 \text { concrete was placed on the dome from } \\
\text { 8:40 a.m. to 2:15 p.m. }\end{array}$ & Construction \\
\hline 204. & 10/20/75 & JGCD & 101 & $\begin{array}{l}\text { Tank } 101 \text { ran out concrete had to order back } 7.5 \\
\text { cubic yards. }\end{array}$ & Issue \\
\hline 205. & $10 / 20 / 75$ & JGCD & 101 & $\begin{array}{l}\text { Tank } 101 \text { had a leak } 1 \text { foot West of } 42 \text { " riser at the } \\
\text { center. Air and water was bubbling through the } \\
\text { concrete (very slowly). }\end{array}$ & Issue \\
\hline 206. & $10 / 24 / 75$ & JGCD/JMJ & 103 & $\begin{array}{l}\text { Tank } 103 \text { placed concrete in haunch from 7:15 } \\
\text { a.m. to 6:30 p.m. }\end{array}$ & Construction \\
\hline 207. & $10 / 27 / 75$ & JGC & 103 & Tank 103 concrete was damaged. P 167 & Issue \\
\hline 208. & $10 / 27 / 75$ & JMJ & 101 & $\begin{array}{l}\text { Investigated water/air bubbling incident on Tank } \\
101 \text { dome concrete. }\end{array}$ & Issue \\
\hline 209. & $10 / 28 / 75$ & JGCD & 103 & Honeycomb Tank 103. & Issue \\
\hline 210. & $10 / 30 / 75$ & JGCD/JMJ & 103 & $\begin{array}{l}\text { Tank } 103 \text { dome concrete was placed between 8:30 } \\
\text { a.m. and 2:30 p.m. }\end{array}$ & Construction \\
\hline 211. & $10 / 31 / 75$ & JMJ & 103 & $\begin{array}{l}\text { Two concrete cylinders from Tank } 103 \text { haunch } \\
\text { broke at } 3130 \text { and } 3180 \text {. Backfill authorized, but } \\
\text { not to extend up to dome area poured 10/30/75. }\end{array}$ & Construction \\
\hline 212. & $11 / 1 / 75$ & JGCD & 103 & $\begin{array}{l}\text { Tank farm back filled with } 3 \text { D-9 Cats during an } \\
11.5 \text { hour shift, which place } 2,500 \text { cubic yards of } \\
\text { backfill. The backfill was placed in } 6 \text { inch lifts. }\end{array}$ & Construction \\
\hline 213. & $11 / 11 / 75$ & JGCD & $\begin{array}{l}101 \\
\text { and } \\
103\end{array}$ & Back filling Tank 101 and 103. & Construction \\
\hline 214. & $11 / 11 / 75$ & JGCD & & Dowels reversed for the pump pit. & Issue \\
\hline
\end{tabular}


RPP-RPT-54819, Rev. 0

\begin{tabular}{|c|c|c|c|c|c|}
\hline No. & Date & $\begin{array}{l}\text { Initials of } \\
\text { Inspector }\end{array}$ & Tank & Comments & Event Type \\
\hline 215. & $11 / 13 / 75$ & JGCD & & $\begin{array}{l}\text { Formed A\&B valve pits and drain pit. Back } \\
\text { filling on Tank 101. Place steel for A\&B pits. }\end{array}$ & Construction \\
\hline 216. & $11 / 3 / 75$ & JMJ & & $\begin{array}{l}\text { Backfill completed at 3:00 p.m. NCR to be raised } \\
\text { to document presence of rocks larger than 3”. }\end{array}$ & Construction \\
\hline 217. & $12 / 29 / 75$ & JGCD & 101 & Formed walls for Tank 101 pump pit. & Construction \\
\hline 218. & $4 / 22 / 76$ & HWD & & $\begin{array}{l}\text { Backfilling on south side A\&B pits. Applied } \\
\text { primer and sealer in pits } 03 \mathrm{C}, 03 \mathrm{~B} \text {, and 03A. }\end{array}$ & Construction \\
\hline
\end{tabular}




\section{APPENDIX B 241-SY WELD MAPS}

\begin{tabular}{lc}
\hline \multicolumn{1}{c}{ Figure } & Page \\
\hline App Figure B-1. Tank SY-101 Primary Tank Bottom Weld Map & B-2 \\
\hline App Figure B-2. Tank SY-102 Primary Bottom Weld Map & B-3 \\
\hline App Figure B-3. Tank SY-103 Primary Bottom Weld Map & B-4 \\
\hline App Figure B-4. Tank SY-101 Secondary Bottom Weld Map & B-5 \\
\hline App Figure B-5. Tank SY-102 Secondary Bottom Weld Map & B-6 \\
\hline App Figure B-6. Tank SY-103 Secondary Bottom Weld Map & B-7 \\
\hline App Figure B-7. SY-101 Primary Shell Weld Map & B-8 \\
\hline App Figure B-8. SY-102 Primary Shell Weld Map & B-9 \\
\hline App Figure B-9. SY-103 Primary Shell Weld Map & B-10 \\
\hline App Figure B-10. SY-101 Secondary Shell Weld Map & B-11 \\
\hline App Figure B-11. SY-102 Secondary Shell Weld Map & B-12 \\
\hline App Figure B-12. SY-103 Secondary Shell Weld Map & B-13 \\
\hline
\end{tabular}


RPP-RPT-54819, Rev. 0

App Figure B-1. Tank SY-101 Primary Tank Bottom Weld Map

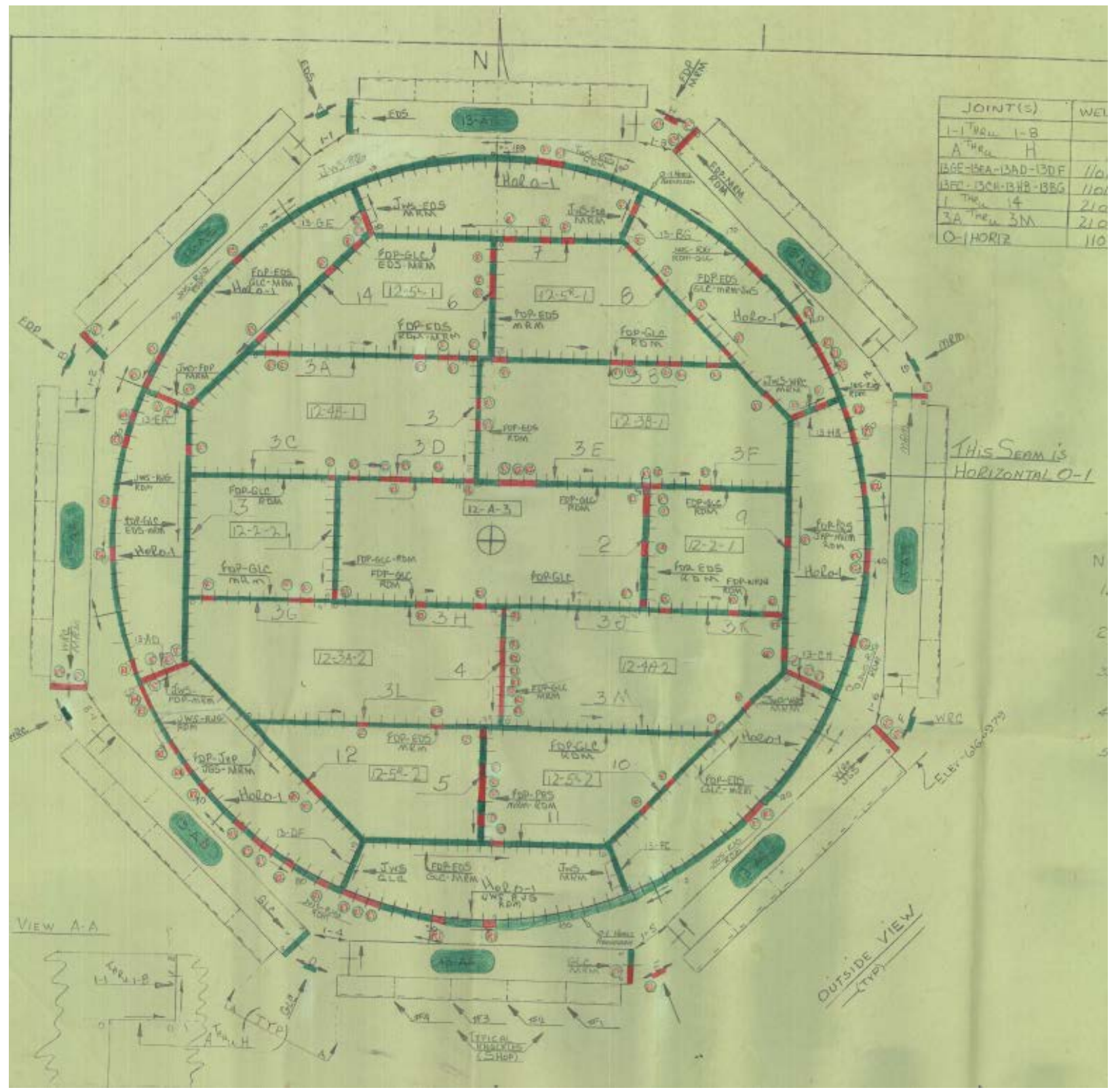


RPP-RPT-54819, Rev. 0

\section{App Figure B-2. Tank SY-102 Primary Bottom Weld Map}

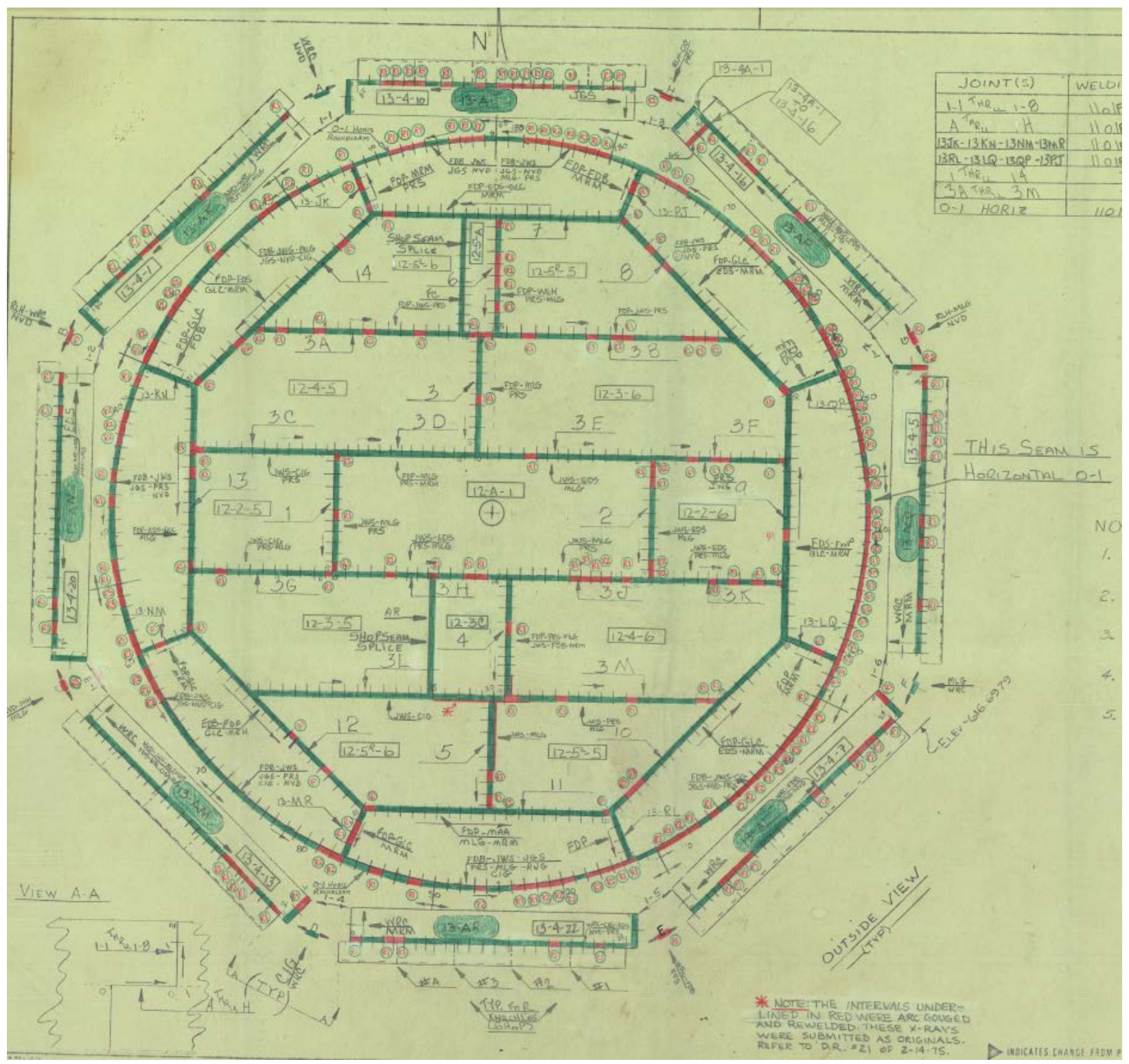


RPP-RPT-54819, Rev. 0

\section{App Figure B-3. Tank SY-103 Primary Bottom Weld Map}

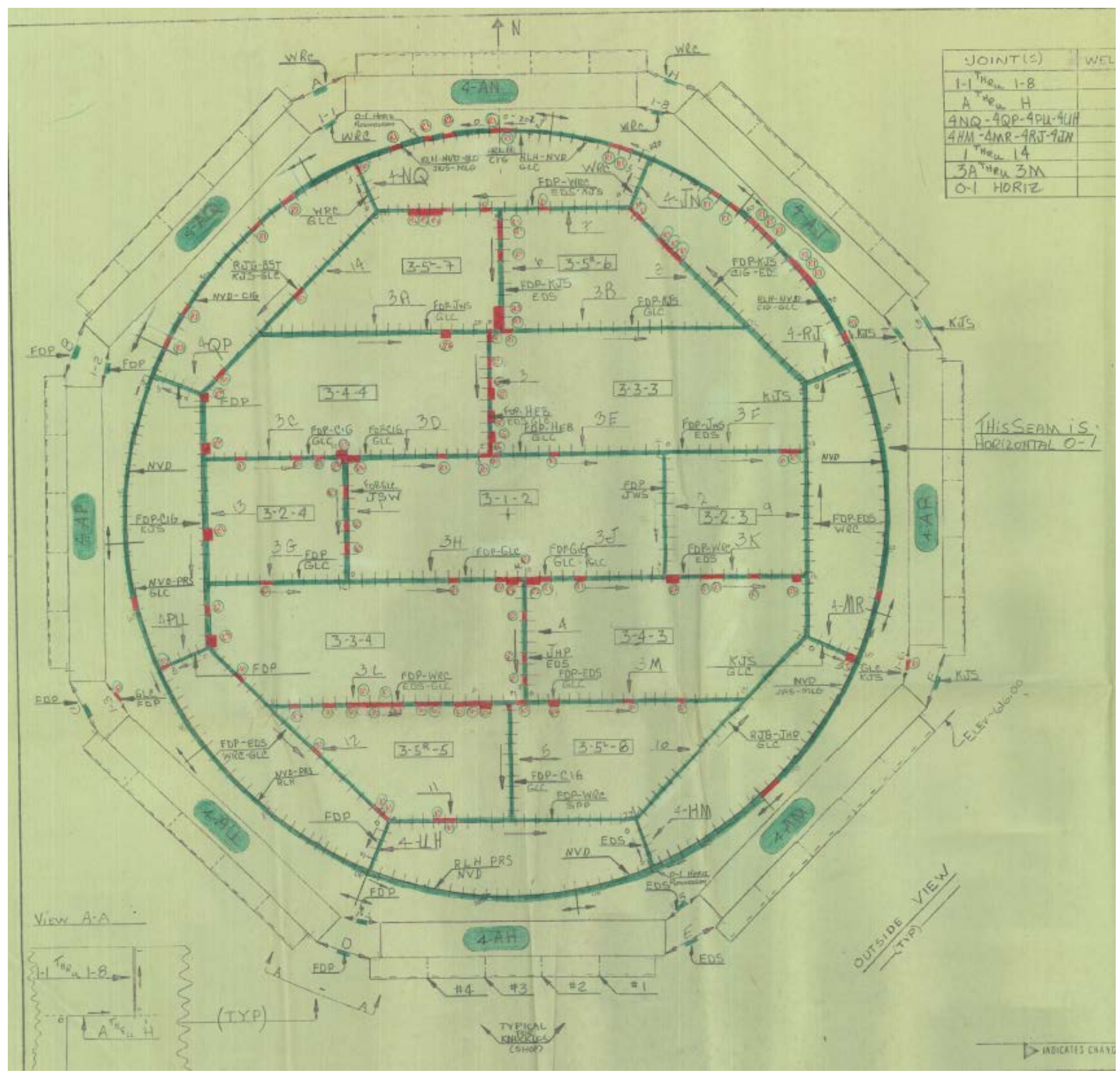


RPP-RPT-54819, Rev. 0

\section{App Figure B-4. Tank SY-101 Secondary Bottom Weld Map}

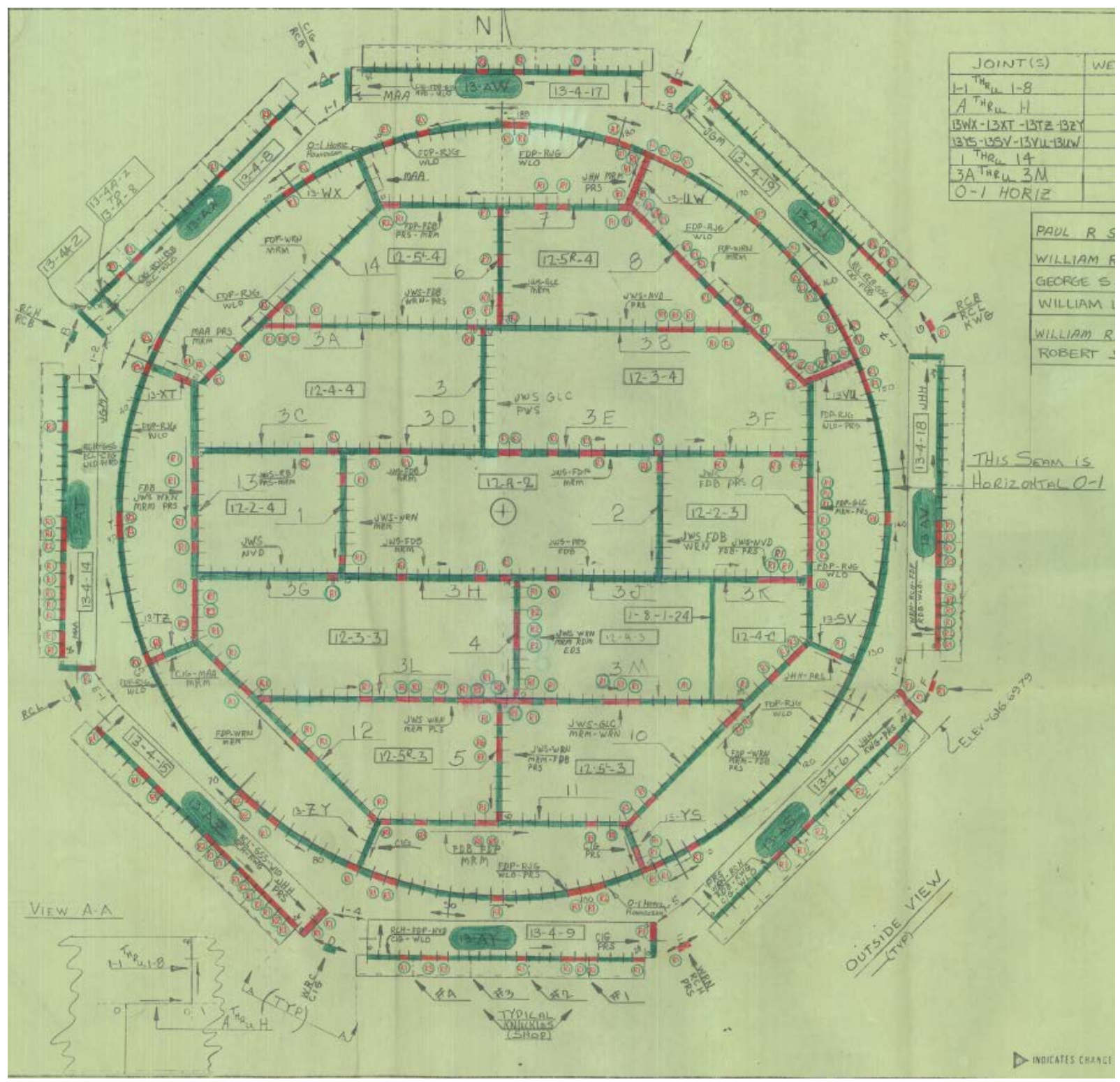


RPP-RPT-54819, Rev. 0

\section{App Figure B-5. Tank SY-102 Secondary Bottom Weld Map}

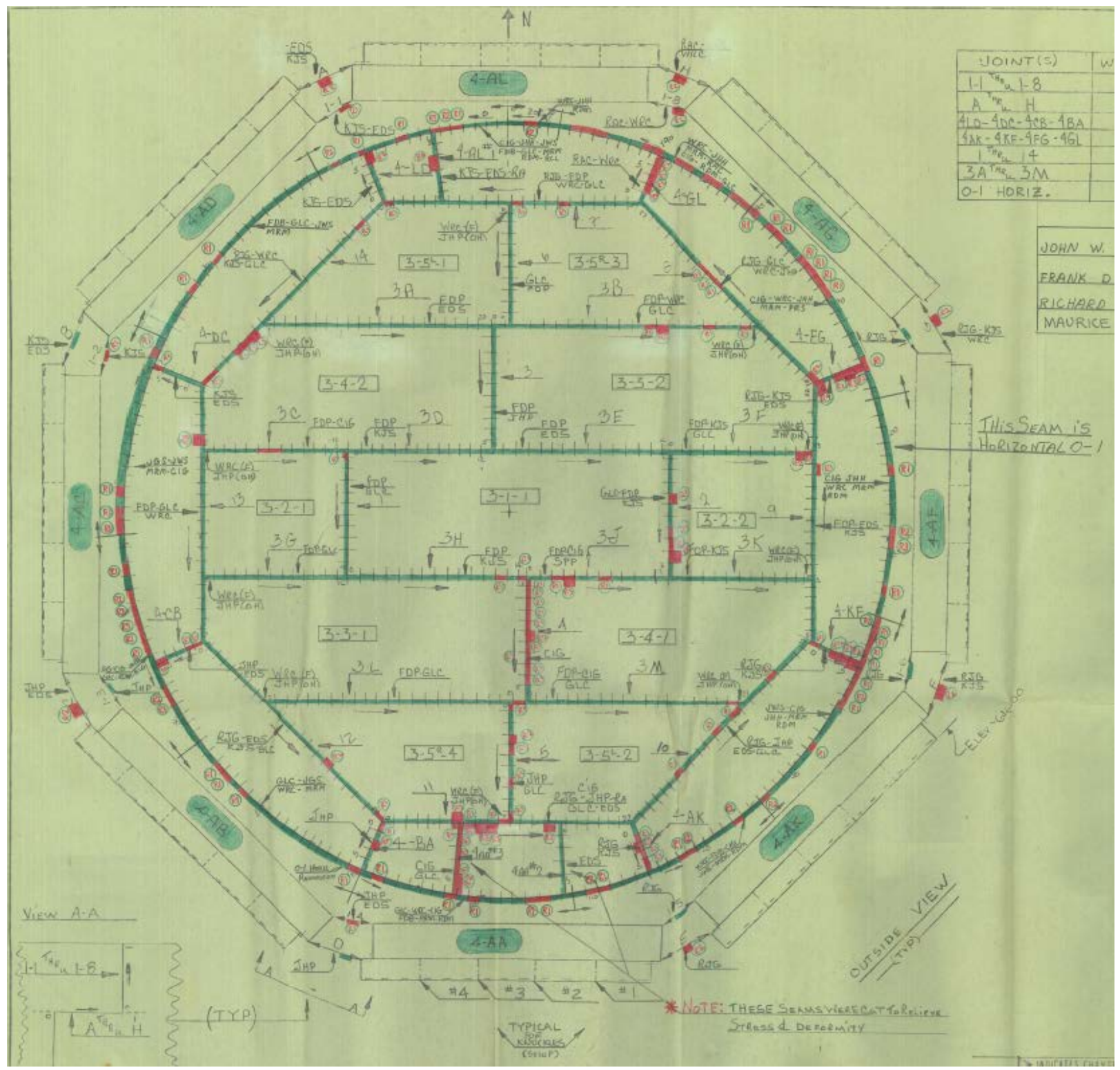


RPP-RPT-54819, Rev. 0

\section{App Figure B-6. Tank SY-103 Secondary Bottom Weld Map}

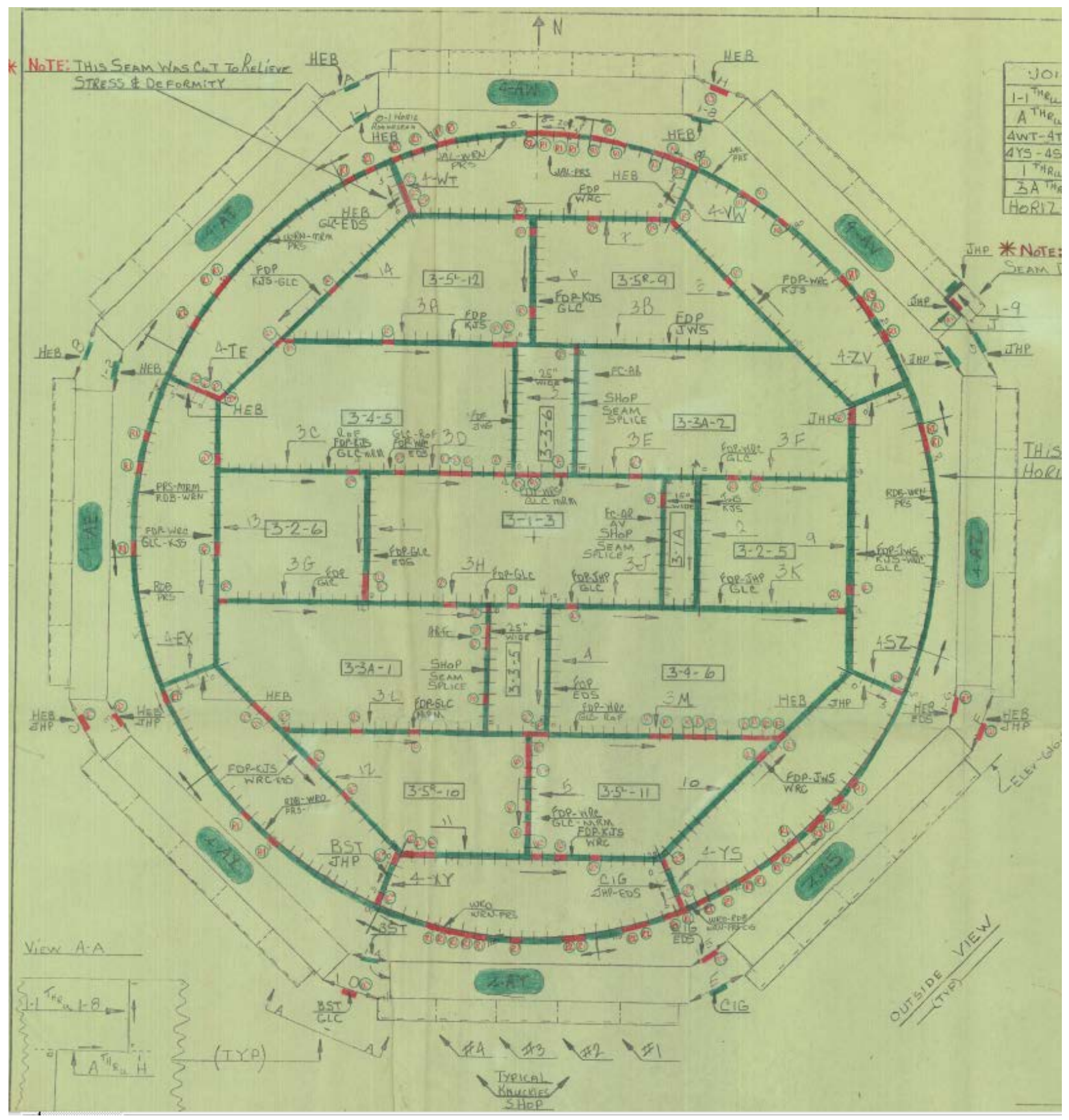

B-7 


\section{App Figure B-7. SY-101 Primary Shell Weld Map}
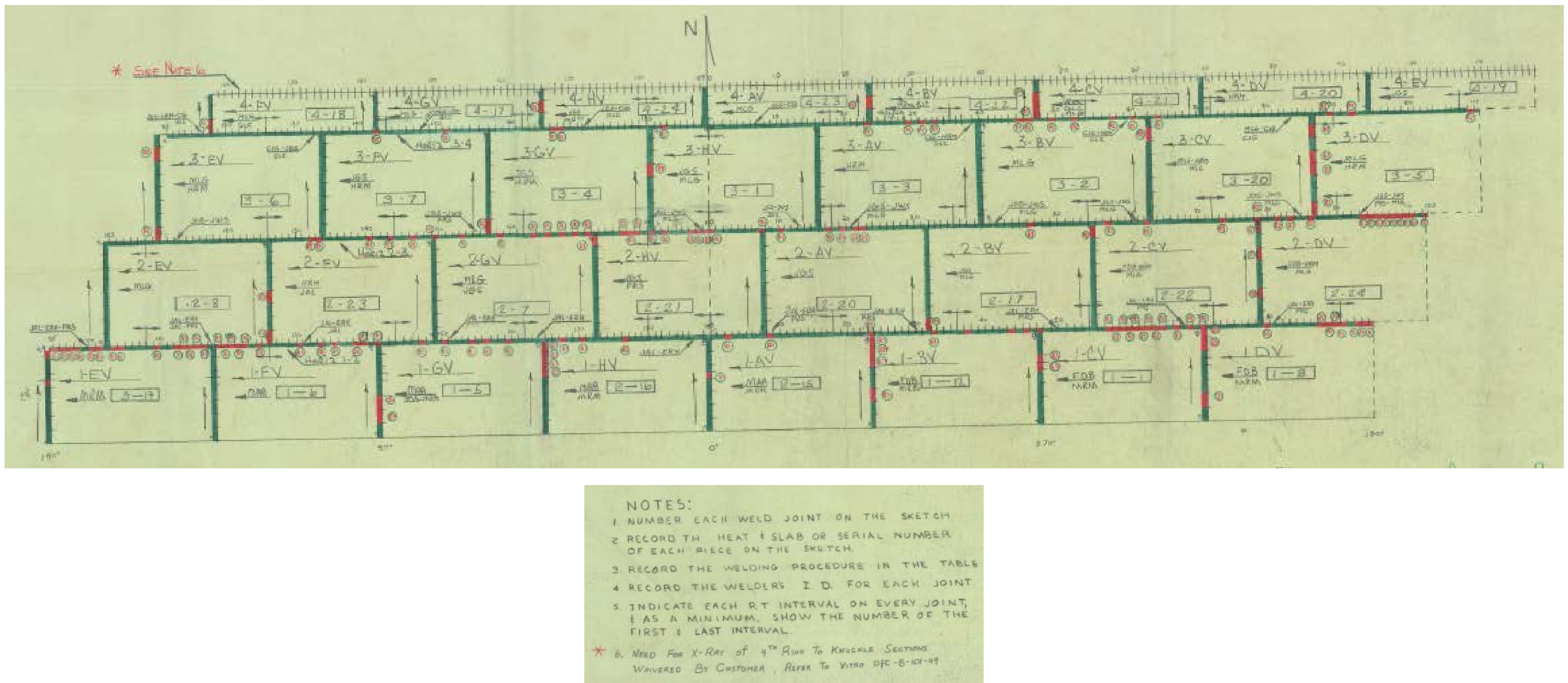
RPP-RPT-54819, Rev. 0

\section{App Figure B-8. SY-102 Primary Shell Weld Map}
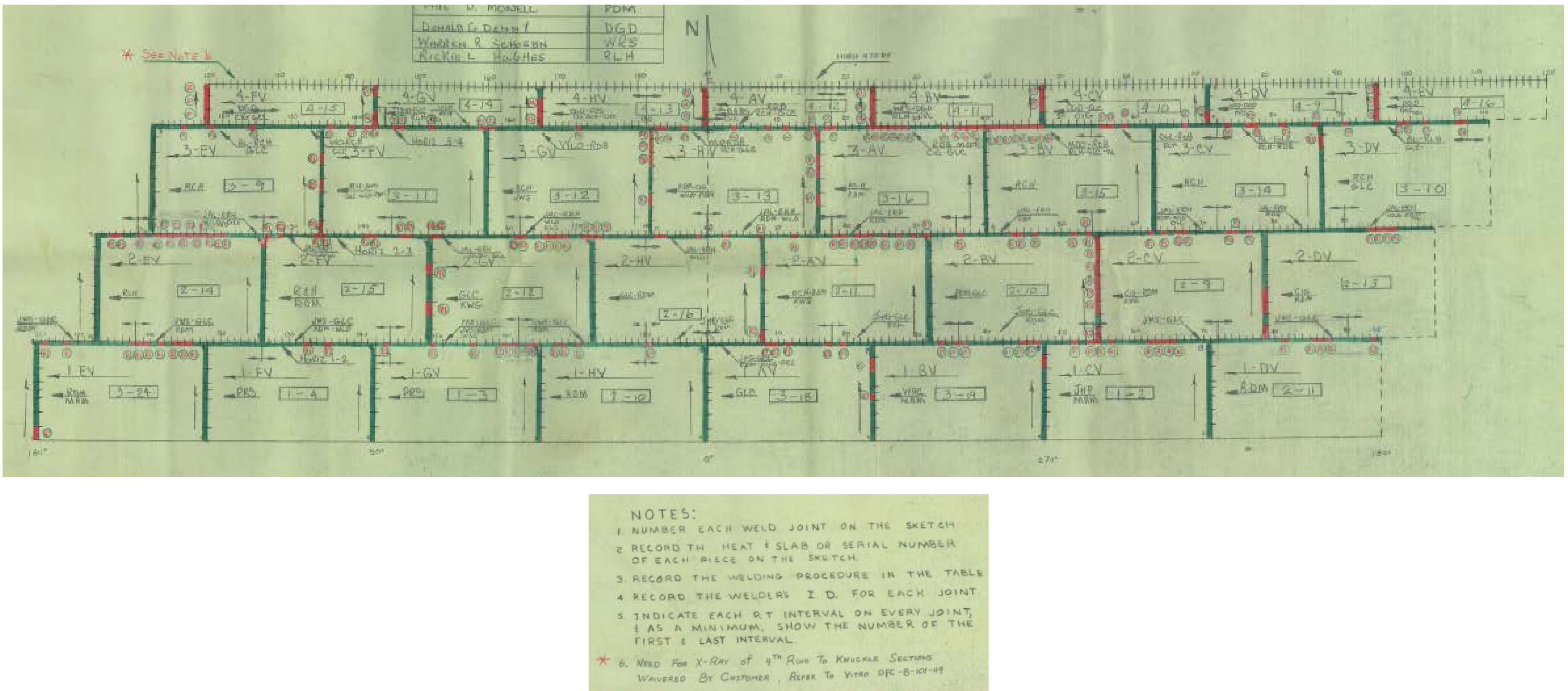


\section{App Figure B-9. SY-103 Primary Shell Weld Map}
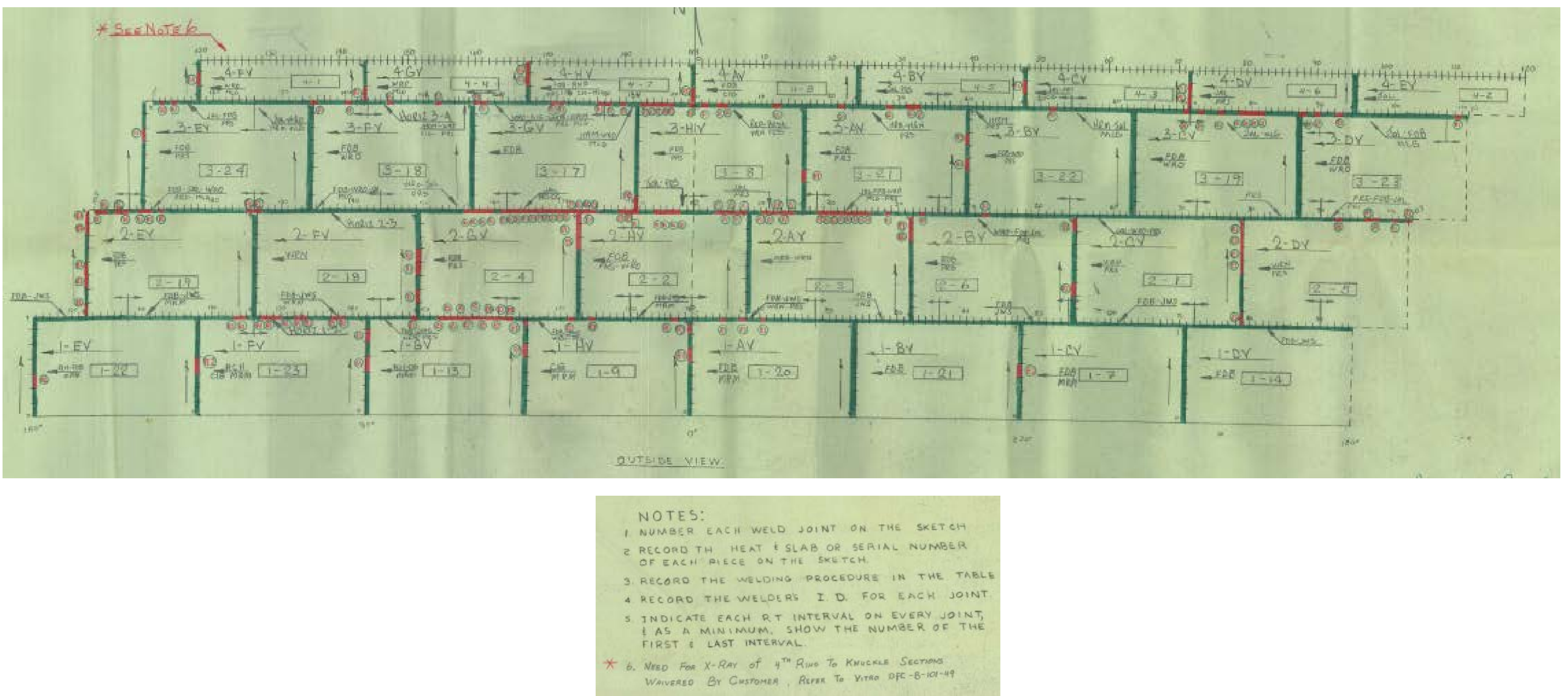


\section{App Figure B-10. SY-101 Secondary Shell Weld Map}

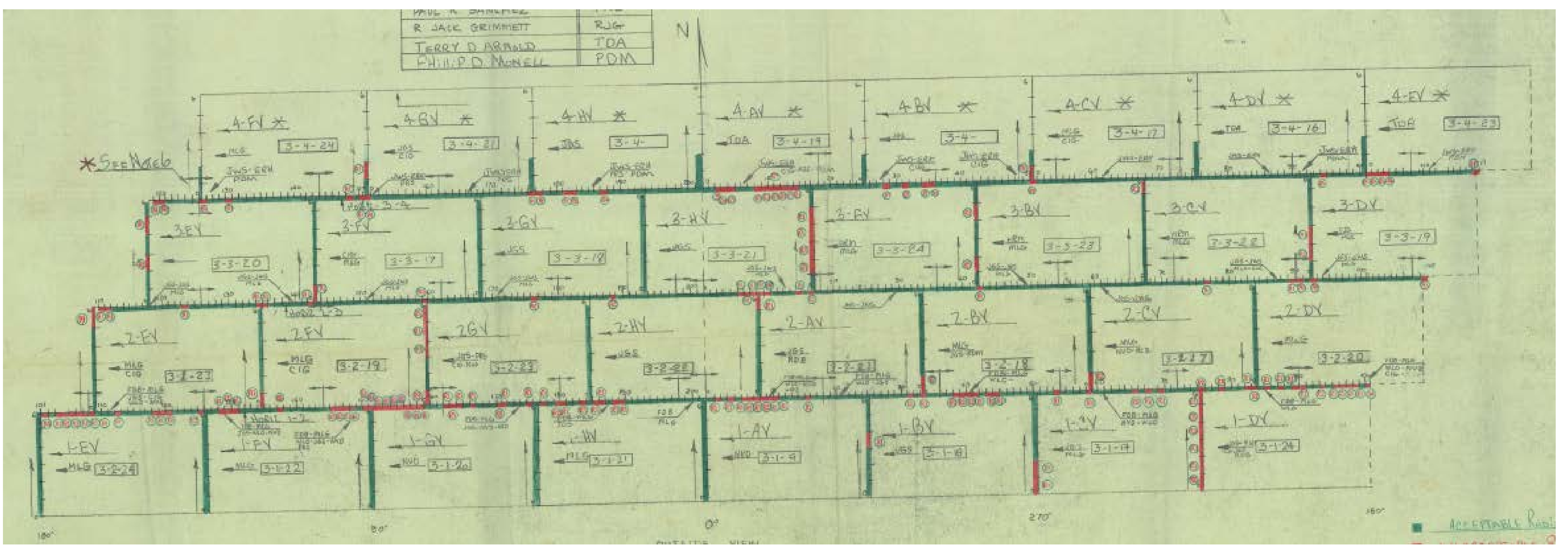




\section{RPP-RPT-54819, Rev. 0}

\section{App Figure B-11. SY-102 Secondary Shell Weld Map}

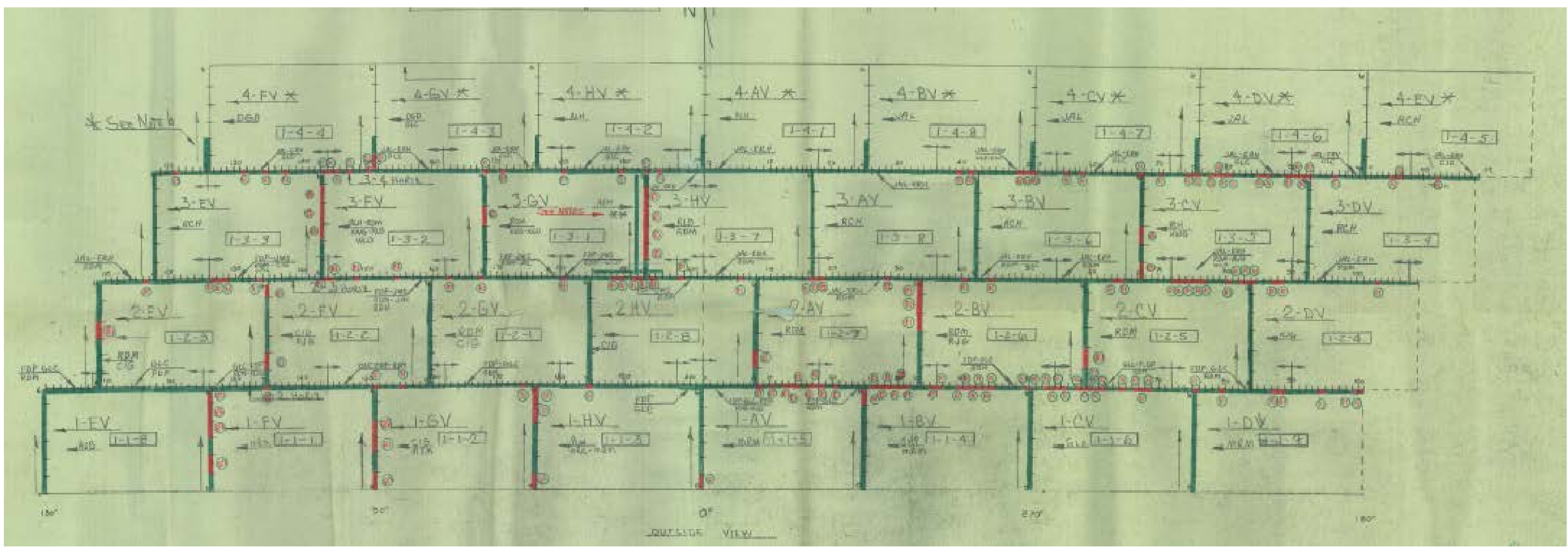




\section{App Figure B-12. SY-103 Secondary Shell Weld Map}

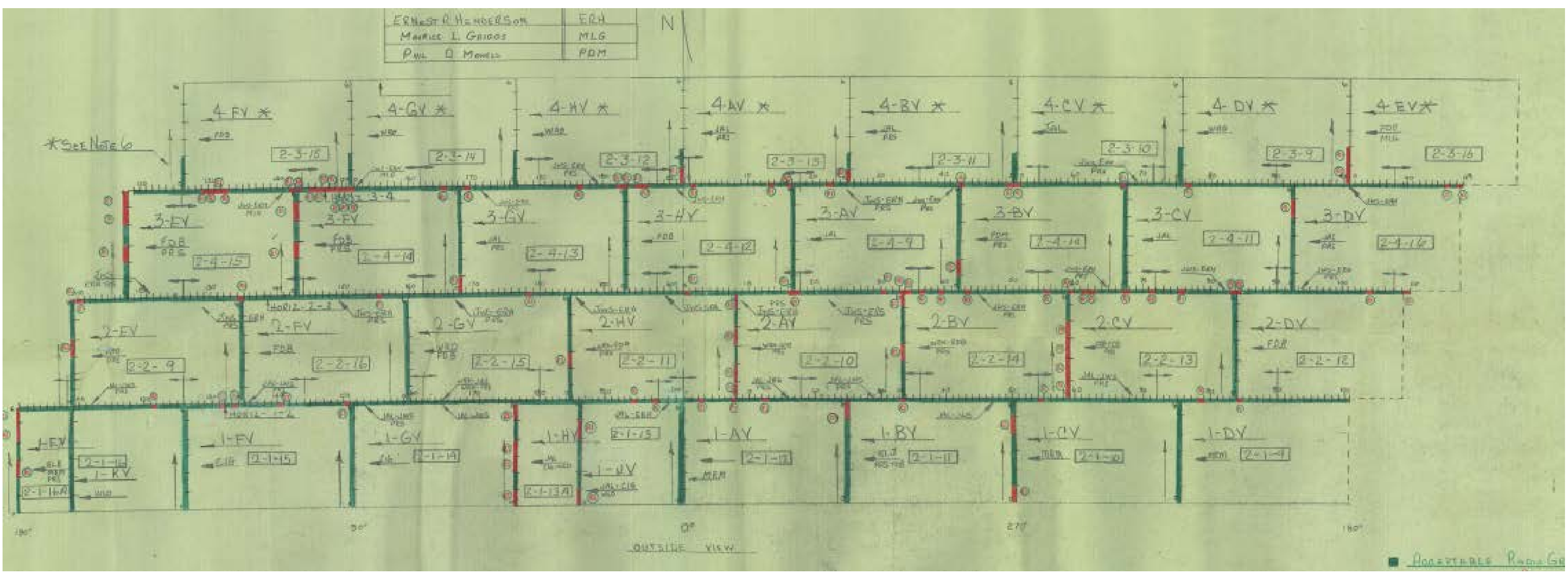




\section{APPENDIX C TANK DEFICIENCY DOCUMENTATION}

\begin{tabular}{|c|c|}
\hline Figure & Page \\
\hline App Figure C-1. Weld Rejection Correspondence & $\mathrm{C}-2$ \\
\hline $\begin{array}{l}\text { App Figure C-2. NCR B-101-34-2307-19, 241-SY Tank Farm Salt Cake Storage } \\
\text { Facility }\end{array}$ & C-6 \\
\hline App Figure C-3. NCR B-101-22-2307-8 & C-10 \\
\hline App Figure C-4. NCR B-101-20-2307-6 & C-12 \\
\hline App Figure C-5. NCR B-101-21-2307-7 & C-15 \\
\hline App Figure C-6. NCR B-101-24-2307-9 & C-18 \\
\hline App Figure C-7. Oct 1, 1975 Letter to J.F. Albaugh & C-20 \\
\hline App Figure C-8. May 4, 1976 Letter to V.D. Schrag & $\mathrm{C}-22$ \\
\hline App Figure C-9. Record of Design/Field Change B-101-128 & C-24 \\
\hline App Figure C-10. SY-101 Grout Out-of-Tolerance Distortion & C-32 \\
\hline App Figure C-11. SY-101 Grout Correspondence & C-36 \\
\hline App Figure C-12. Investigation of Tank SY-102 Insulating Refractory & C-47 \\
\hline App Figure C-13. NCR B-101-32-2307-17 & C-48 \\
\hline $\begin{array}{l}\text { App Figure C-14. NCR B-101-19-2307-5, 241-SY Tank Farm Salt Cake Storage } \\
\text { Facilities }\end{array}$ & C-51 \\
\hline $\begin{array}{l}\text { App Figure C-15. NCR B-101-25-2307-10, 241-SY Tank Farm Salt Cake Storage } \\
\text { Facilities }\end{array}$ & C-59 \\
\hline App Figure C-16. NCR B-101-26-2307-11, 241-SY Tank Farm Storage Facilities & C-60 \\
\hline $\begin{array}{l}\text { App Figure C-17. NCR B-101-33-2307-18, 241-SY Tank Farm Salt Cake Storage } \\
\text { Facilities }\end{array}$ & C-62 \\
\hline $\begin{array}{l}\text { App Figure C-18. NCR B-101-35-2307-20, 241-SY Tank Farm Salt Cake Storage } \\
\text { Facilities }\end{array}$ & C-63 \\
\hline App Figure C-19. Tank SY-101 Secondary Liner Circumference Deficiency Report & C-65 \\
\hline $\begin{array}{l}\text { App Figure C-20. NCR B-101-29-2307-14, 241-SY Tank Farm Salt Cake Storage } \\
\text { Facilities }\end{array}$ & C-66 \\
\hline App Figure C-21. Tank SY-102 Secondary Liner Circumference Deficiency Report & C-67 \\
\hline $\begin{array}{l}\text { App Figure C-22. NCR B-101-31-2307-16, 241-SY Tank Farm Salt Cake Storage } \\
\text { Facilities }\end{array}$ & C-68 \\
\hline App Figure C-23. Tank SY-103 Primary Local Distortion Deficiency Report & C-70 \\
\hline $\begin{array}{l}\text { App Figure C-24. NCR B-101-38-2307-22, 241-SY Tank Farm Salt Cake Storage } \\
\text { Facilities }\end{array}$ & C-72 \\
\hline App Figure C-25. NCR B-101-37-2307-21 & C-75 \\
\hline App Figure C-26. NCR B-101-39-2307-23 & C-77 \\
\hline
\end{tabular}




\section{App Figure C-1. Weld Rejection Correspondence}

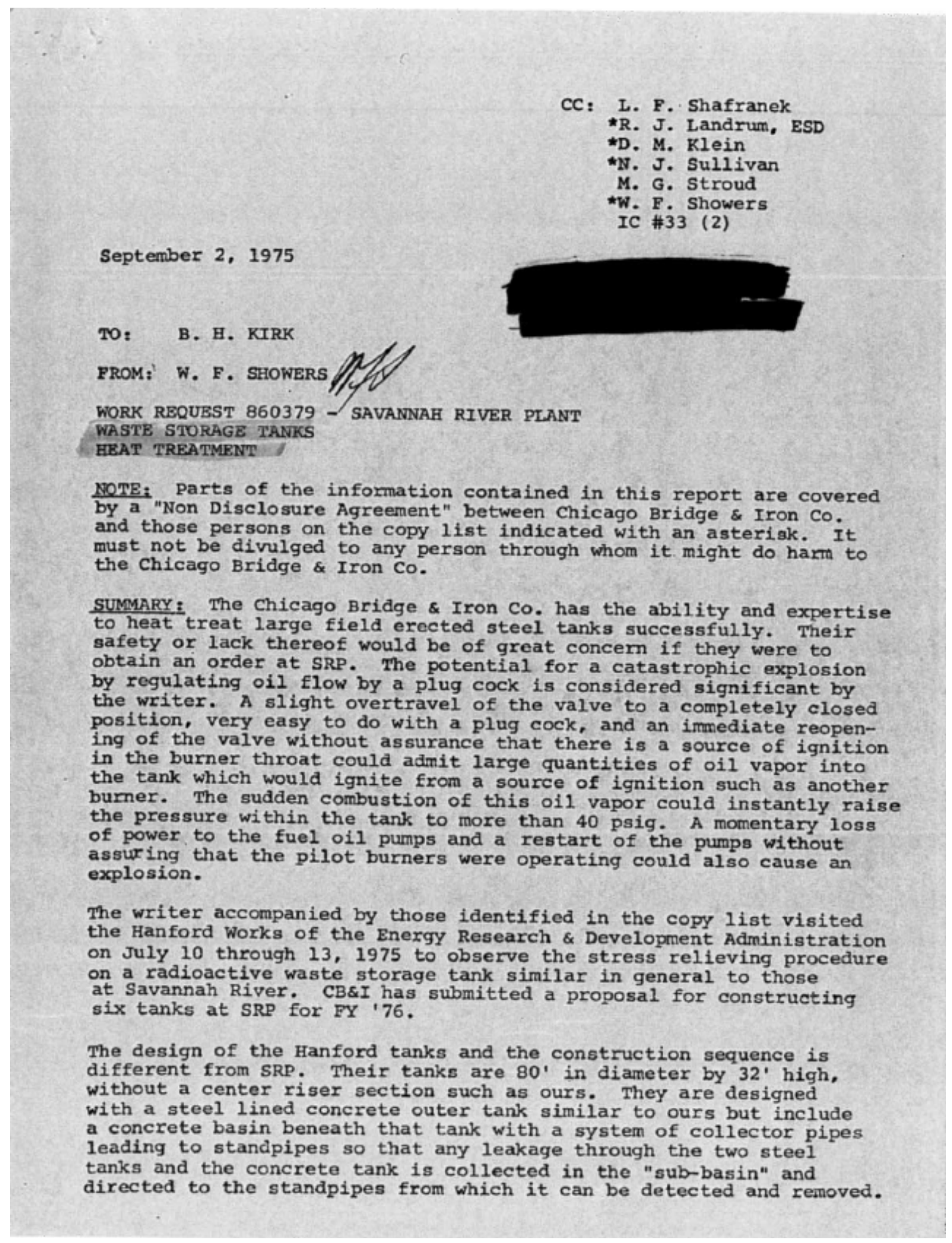


$-2-$

B. H. Kirk

September 2, 1975

The construction sequence required partial encasement and backfilling to proceed with the construction of the waste tank. This permitted much work to proceed from "grade" at the level of backfill and greatly reduced the height of the top of the tank above grade during stress relieving as improvements. The cessation of work while other phases proceeded would be negative aspects, plus the necessity to clean off the concrete joints before pouring leaves. The wisdom of this sequence is in doubt.

This 'design will be used at SRP for the FY '75 and later tanks but we will continue to erect and stress relleve the tank before erecting the outer tank.

The insulating refractory tank support was an 8 " thick layer of $\mathrm{CE} \# 50$. This material gave a $150^{\circ} \mathrm{F}$ maximum concrete tomperature beneath the refractory.

The stress relieving procedure as developed by Chicago Bridge \& Iron Co.. was well executed, based on long experience with many large field erected tanks. The largest was a containment vessel for a nuclear power house, $110 \mathrm{ft}$ in diameter by $220 \mathrm{ft} \mathrm{high}$, which was constructed of $3^{\prime \prime}$ steel plate on the bottom and 2 " plate on the top with intermediate thicknesses in between.

For "proprietary" information reasons and safety, we were not permitted on top of the tank. From discussion and observation, we determined that the heating system consisted of a $4 \mathrm{ft}$ dianeter steel tube resting on supporting legs on the bottom center of the tank. Four, approximately $10 \mathrm{million} \mathrm{btu} / \mathrm{hr}$ high pressure (90 100 psi) air atomizing oil burners, located possibly 3 to $4 \mathrm{ft}$ from the tank bottorn, discharged fiame into the tank. I have reason to believe that these burners were located at some tangent angle to the tube to cause a swirling motion of the hot gasses in the tank. The venturi action of the air-oil stream induces combustion air through the refractory burner throats. The combustion air is drawn down through the $4 \mathrm{ft}$ diameter tube, which is insulated, and can be entered, if necessary, while the burners are in service.

A number of dampered ports discharge gas at a safe elevation above the tank. These dampers are operated by rods, from the operating platform in the center, to equalize the temperatures at various locations throughout the tank.

No attempt is made to maintain any specified pressure within the tank. The top of the tank is supported by temporary stiffeners welded across the top of the tank. These are burned off and the welds ground smooth after the stress relieving operation. The burner support tube is removed and a $6^{\prime}$ plate cover is welded over the center of the tank after stress relieving. Since this weld is above any possible operating liquid level, it does not require stress relieving. 
$-3-$

B. H. Kirk

September 2, 1975

The tank is insulated during stress relieving by two layers of wirecloth faced mineral wool batts banded around the tank with steel strapping. This is satisfactory for the desert, but could be a problem if a heavy rain would occur unless a weatherproof covering were applied on a tent like structure over the tank.

The burners are fired with diesel fuel using two air compressors with a spare. Control is strictly manual from visual observation of the flame through inspection ports in the top of the tank.

Plug cocks on a manifold are operated by wrenches using pressure gages on the oil and air lines to the individual buiners as a guide. verbal instructions are shouted from the operator on top of the tank to the man at the valve manifold. The burners are visible from the platform on top of the tank through ports.

Propane fired pilot burners located in the oil burner throats are operated continuously. No monitoring of the pilot burners or the main oil burners is attempted. Solenoid oil valves were noted among the parts in various boxes shipped in for the stress relieving operation. The CB\&I supervisor commented that the flame safety equipment was "too much trouble to keep operating" from false shutdowns, etc., so was not used.

Thermocouples were located in the insulating refractory supporting the tank as well as selected spots on the tank bottom, sides and top for a total of about 150 . These results were recorded on 12 " strip chart recorders and manually logged on data sheets. We received a copy of this $\mathrm{log}$ and diagrams of the thermocouple location, which is available for inspection.

The heat up operation had started on July 10 just before noon, and on our visit late in the evening was progressing according to schedule, within the specifications as issued by ARCHO, the operating contractor for the Hanford site: The heat up continued for the next day, July 11 , and late in the evening reached the $1000^{\circ} \mathrm{F}$ minimum specified by ARCHO. Du Pont specifies $1100^{\circ} \mathrm{F}$ for SRP. Mr. Iandrum had discussions with various Hanford personnel who referred to test work allegedly done by Battelle Northwest to support the lower temperature for a longer period of time. We requested copies of this test data or a reference where we might examine the data.

There was a supposition on the part of some that the limit of the burners had been reached. The writer observed the pressure gages on the burner manifold at about 10:00 pm when the temperature "hold" was in progress. Based on previous experience with similar burners, I would estimate that 20 to $25 \%$ more heat input was available. A more likely reason to limit the maximum temperature might be the tank top support. A review of this temperature iimit with members of ERDA and Jones Construction Co. staff on the following day indicated total 
$-4-$

B. H. Kirk

September 2, 1975

agreement that test data indicated that $1000^{\circ} \mathrm{F}$ stress relieving temperature would prevent stress corrosion and cracking of the tanks.

Mr. O. G. Sikora of CB\&I was in charge of the stress relieving operation. We gained the impression that the technique, and the results, were his responsibility. In view of the proprietary nature of this operation, he was somewhat vague on exactly how CB\&I would stress relieve tanks that they might erect at SRP. He frequently stated "After a contract has been signed, we'11 get together to discuss details on how we'11 do it."

Mr. William Gross, Quality Assurance Engineer for CB\&I, stated that ali x-ray pictures are jointly examined at the site by himself and vitro Co. engineering personnel on a "good" or "bad" basis with no borderline work accepted. The final X-ray pictures are reviewed by the regional CB\&I Quality Assurance Engineer and are filed. Surface defects on the plates were a big problem on the current tank accounting for 8 to $10 \%$ of the rejections.

WFS/ren 
RPP-RPT-54819, Rev. 0

App Figure C-2. NCR B-101-34-2307-19, 241-SY Tank Farm Salt Cake Storage Facility

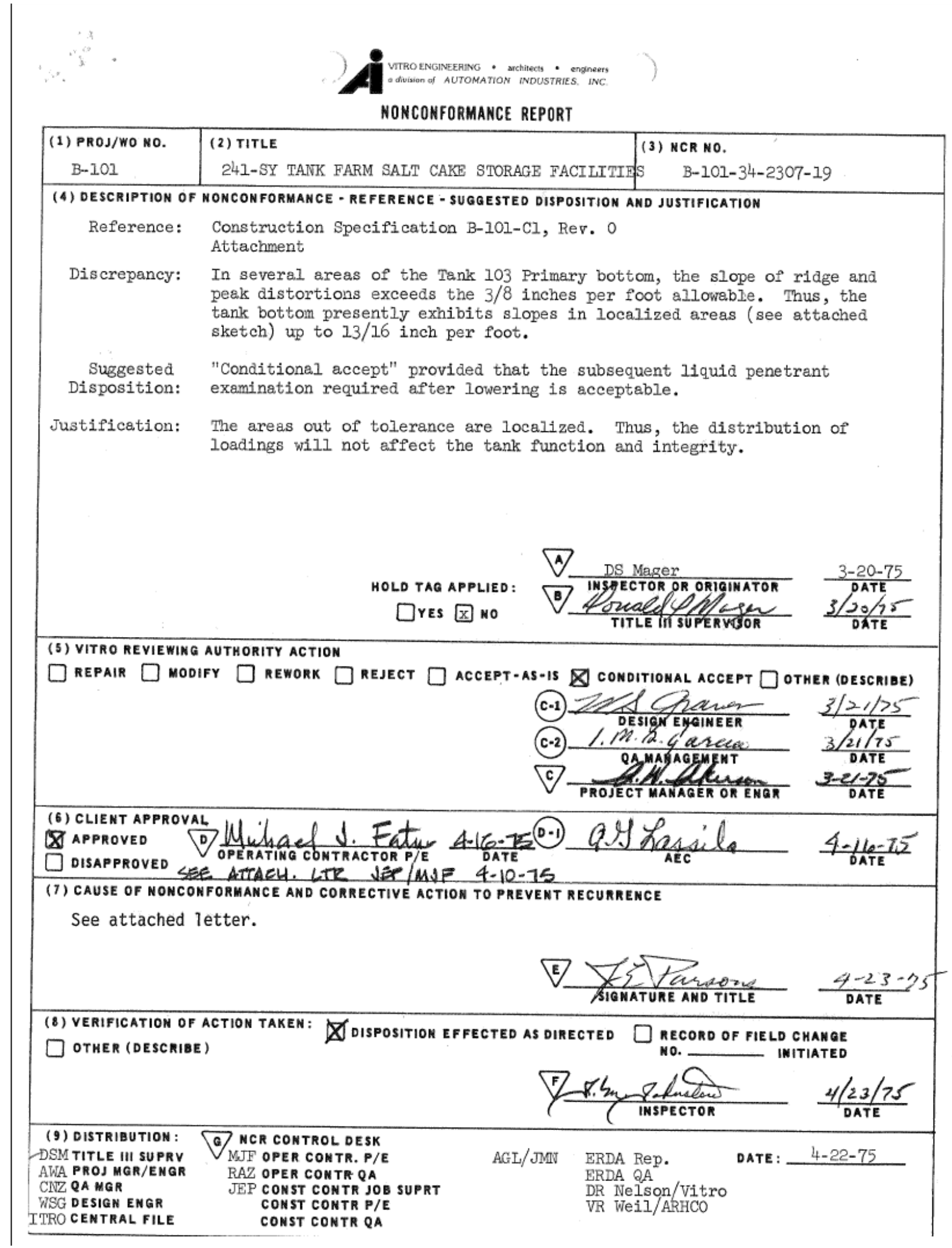


RPP-RPT-54819, Rev. 0

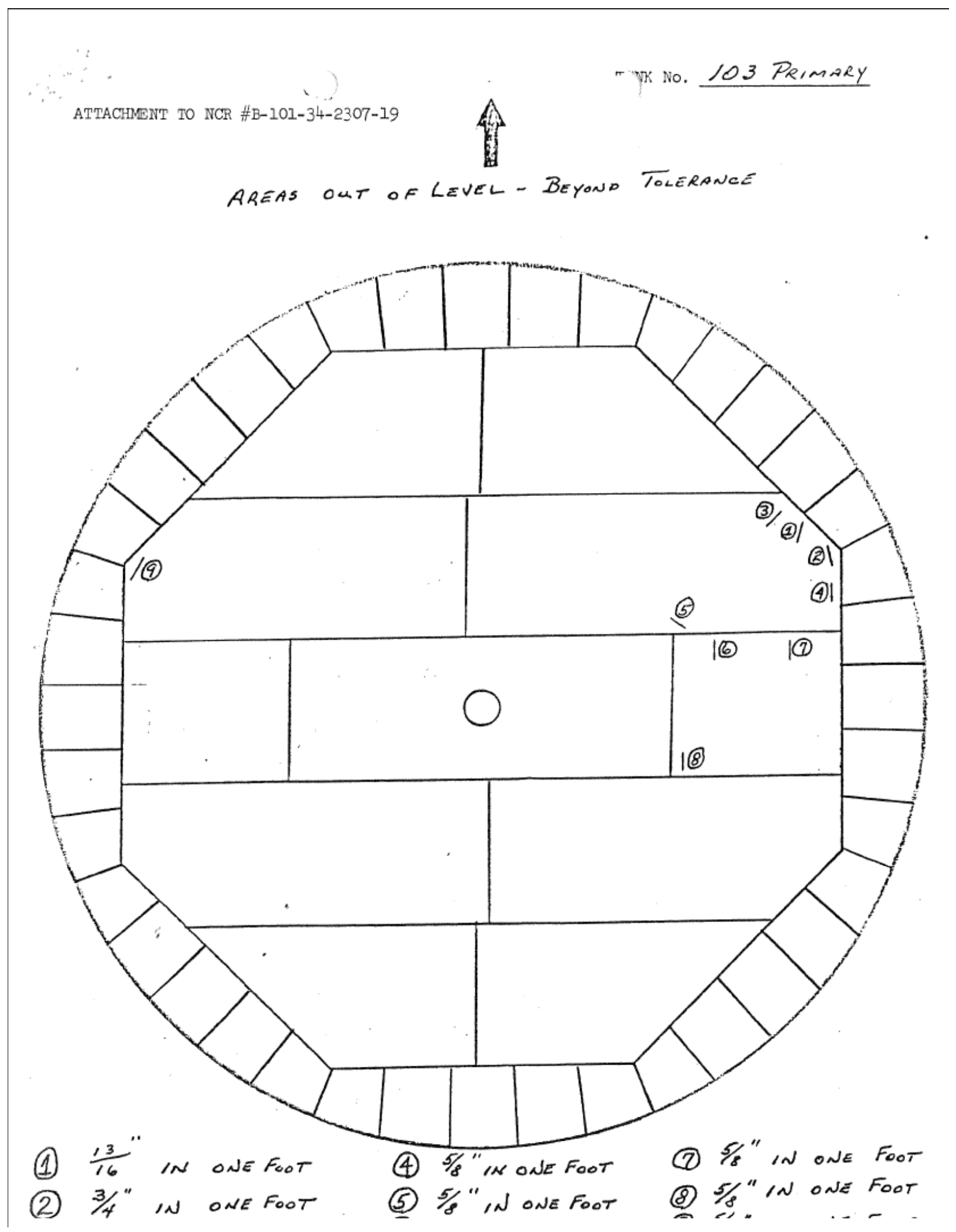


From: JE Parsons

Subject:

Subject non-conformance report documents discrepancies in tank 103 primary bottom. The discrepancy is a conflict in the fabrication as it exists and construction specifications B101-C1 section 14.3. Specifically, "The slopes of peak or ridge distortions shall be gradual and in no case shall be more than 3/8" per foot." As indicated in the above mentioned NCR, the slopes measure up to $13 / 16^{\prime \prime}$ per foot in localized areas.

Project B-101 has six tank bottoms to be fabricated, three secondary and three primary. As a review the following is a historical sequence of events related to this particular slope problem.

1. Deviations in specified slope tolerances were first experienced on the first secondary tank bottom to be fabricated (tank bottom 102). This discrepancy was noted prior to lowering. In an attempt to correct the discrepancy, the contractor made extensive repairs which consisted of cutting open seams, trimming plates and rewelding with the associated NDT. The result of this repair was that other areas then fell out of tolerance and the repaired area itself was marginal. The tank bottom was lowered and after lowering the areas that were out of tolerance moved to new locations. An NCR was written (NCR B101-20-2307-6) and accepted on the basis that the areas out of tolerance were localized and the distribution of loadings would not affect the tank integrity or function.

2. The second secondary tank bottom (tank 101) was then approximately $90 \%$ complete and the same conditions existed (see NCR B101-22-2307-8). Here again locations of discrepancies moved after lowering. The NCR on these discrepancies was also accepted. It was determined that the primary cause of these distortions was the sequencing of the actual welding operations and plate layout.

3. For the third secondary tank bottom the welding sequence was revised in an effort to correct this tolerance problem. This change was only partially successful since the third tank bottom also was out of tolerance. The contractor again attempted to repair the out of tolerance sections by heating and locally deforming the buckled areas. This effort was not successful. This discrepancy was noted and accepted in NCR B101-24-2307-9. 


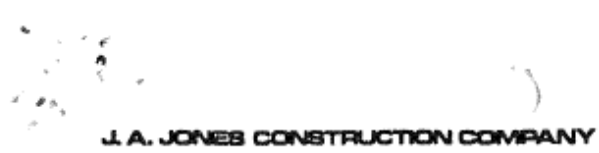

4. As a result of the third secondary bottom, the contractor again extensively modified his welding sequence andadded an elaborate system of jig work in an effort to hold specification tolerances of $3 / 8^{\prime \prime}$ per foot. The first results of this new procedure were evidenced in the primary bottom of tank 102 . On completion of fabrication this primary bottom was out of tolerance, hovever after lowering the areas out of tolerance shifted and reduced so that tolerances were achieved.

5. The same procedure was again used on the tank 101 primary bottom with the following results. The bottom was fabricated and was out of tolerance. One area that was out of tolerance was determined to be a ridge distortion caused by the weld could be fixed by removing and rewelding three seams. This was done and that particular location came within tolerance, however new areas developed which were marginal as to being within tolerance. The bottom was then lowered and the our of tolerance areas redistributed leaving a bottom within tolerance.

6. On the third primary tank bottom (103) the same procedures were followed producing areas out of tolerance. A review of the areas revealed that they were not caused by ridge peaking of the welds and rework of these areas in the manner done on the second tank bottom would not bring them within tolerance. Since the magnitude of these discrepancies were less than had been experienced prior to lowering the last two tank bottoms (primary), it was expected that after lowering they would redistribute and be within the $3 / 8$ " per foot slope. Upon lowering areas that were questionable improved but other areas increased resulting in NCR B101-34-2307-19.

The results of any repairs that could be made to correct the deficient areas are questionable as to their success for the follwoing reasons:

1. Deficient areas move as a result of lowering the tank bottoms and if the the bottom is raised to affect a repair the same area may not be out of tolerance when raised.

2. Past experience on tanks 102 and 101 indicated that reworking seams creates added distortion elsewhere in the tank bottom which could result in a worse new condition than presently exists.

3. Since the discrepancies in the 103 primary bottom are not 1 imited to the seam areas themselves, additional seams would be required to be added to the bottom plates.

Since engineering design has examined the areas and determined that existing discrepancies will not affect the tank function or integrity and because of the inability to guarantee a successful repair, we feel that a repair cannot be justified.

For future tanks this tolerance of $3 / 8^{\prime \prime}$ per foot should be carefully reviewed. This arbitrarily arrived at tolerance has caused expensive and elaborate systems to be employed with very marginal results. Future tank fabrication bids will be considerably higher if this tolerance is left unchanged.

JP:st

CC: ML Marlin 
App Figure C-3. NCR B-101-22-2307-8, 241-SY Tank Farm Salt Cake Storage Facilities

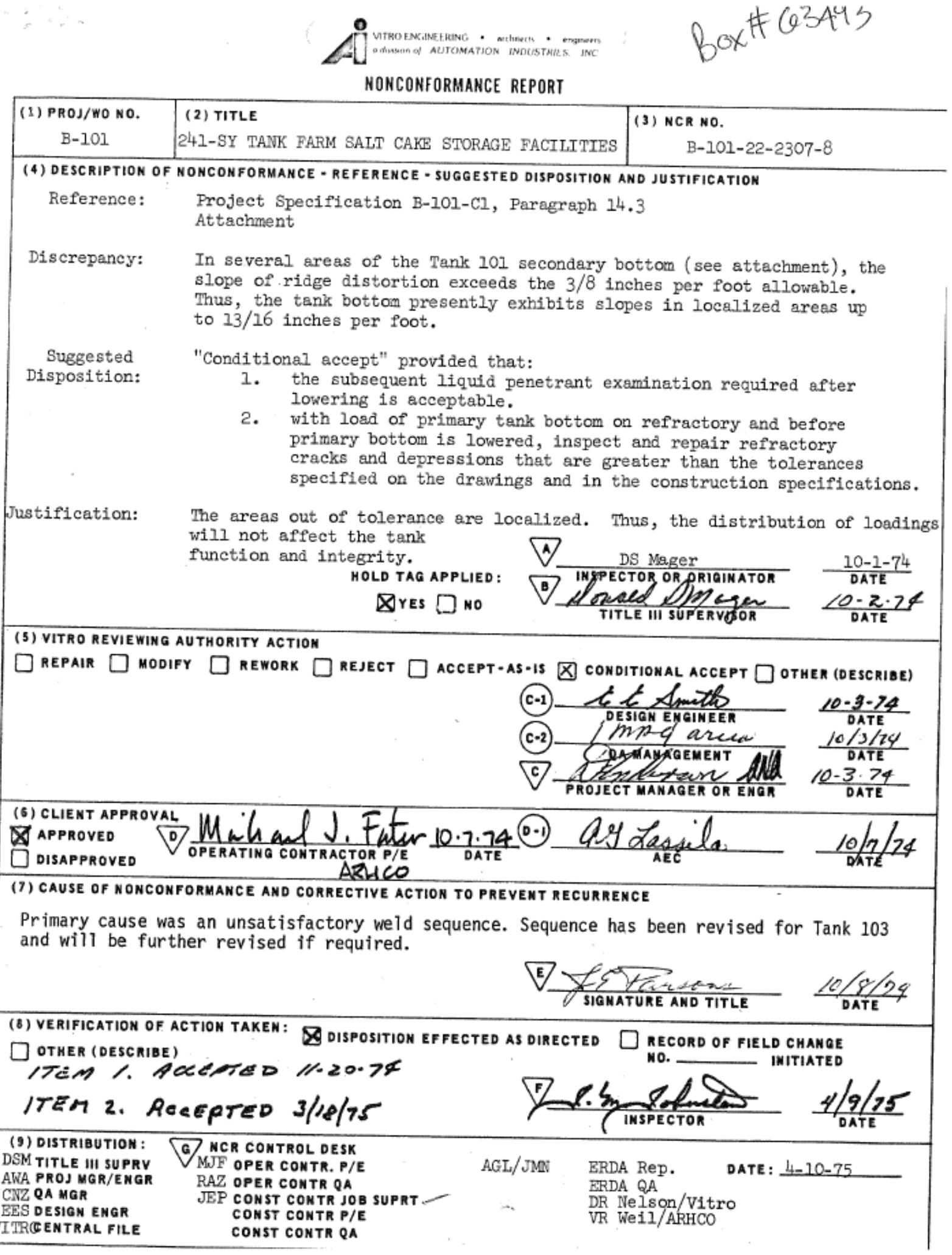


RPP-RPT-54819, Rev. 0

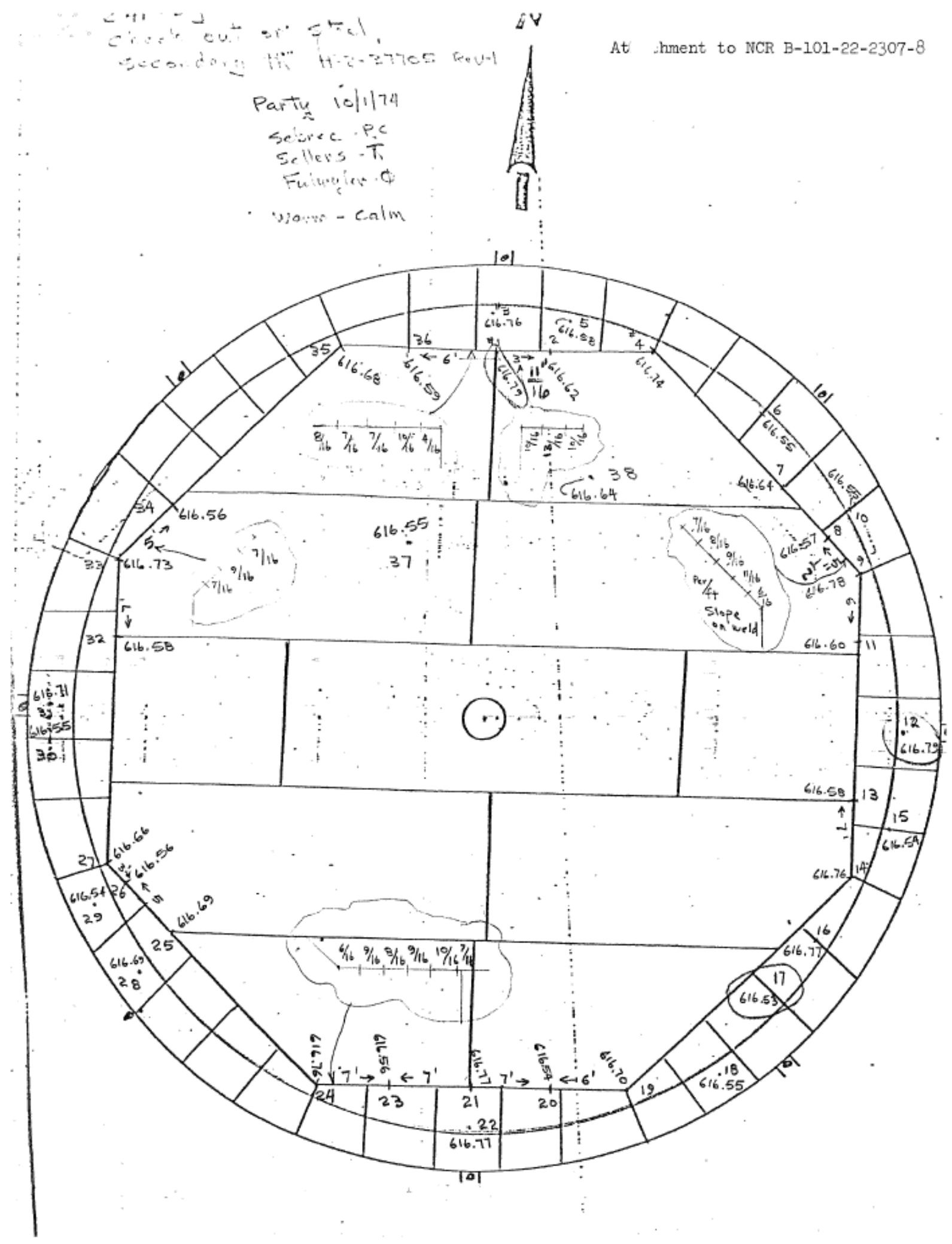


RPP-RPT-54819, Rev. 0

App Figure C-4. NCR B-101-20-2307-6, 241-SY Tank Farm Salt Cake Storage Facilities

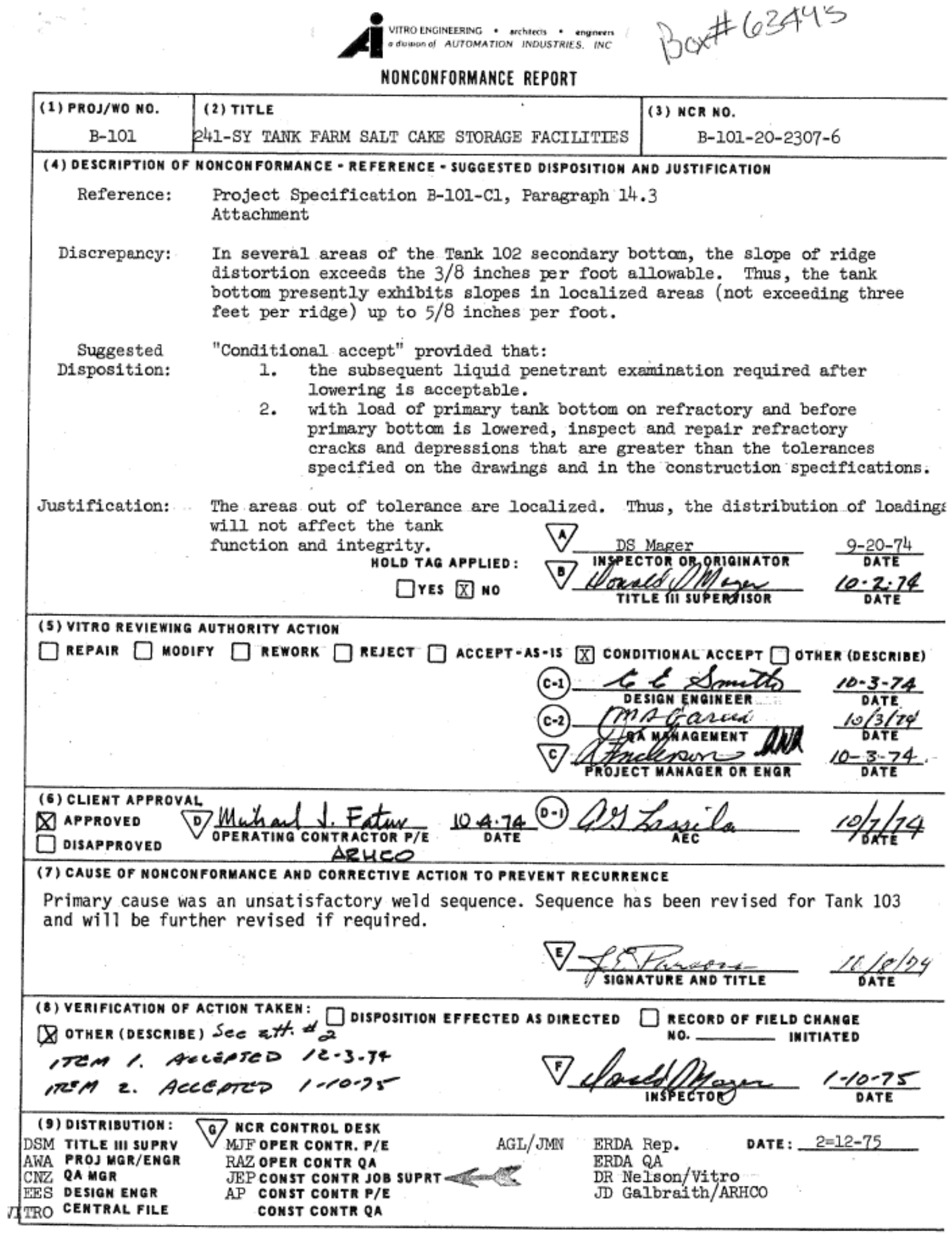


RPP-RPT-54819, Rev. 0

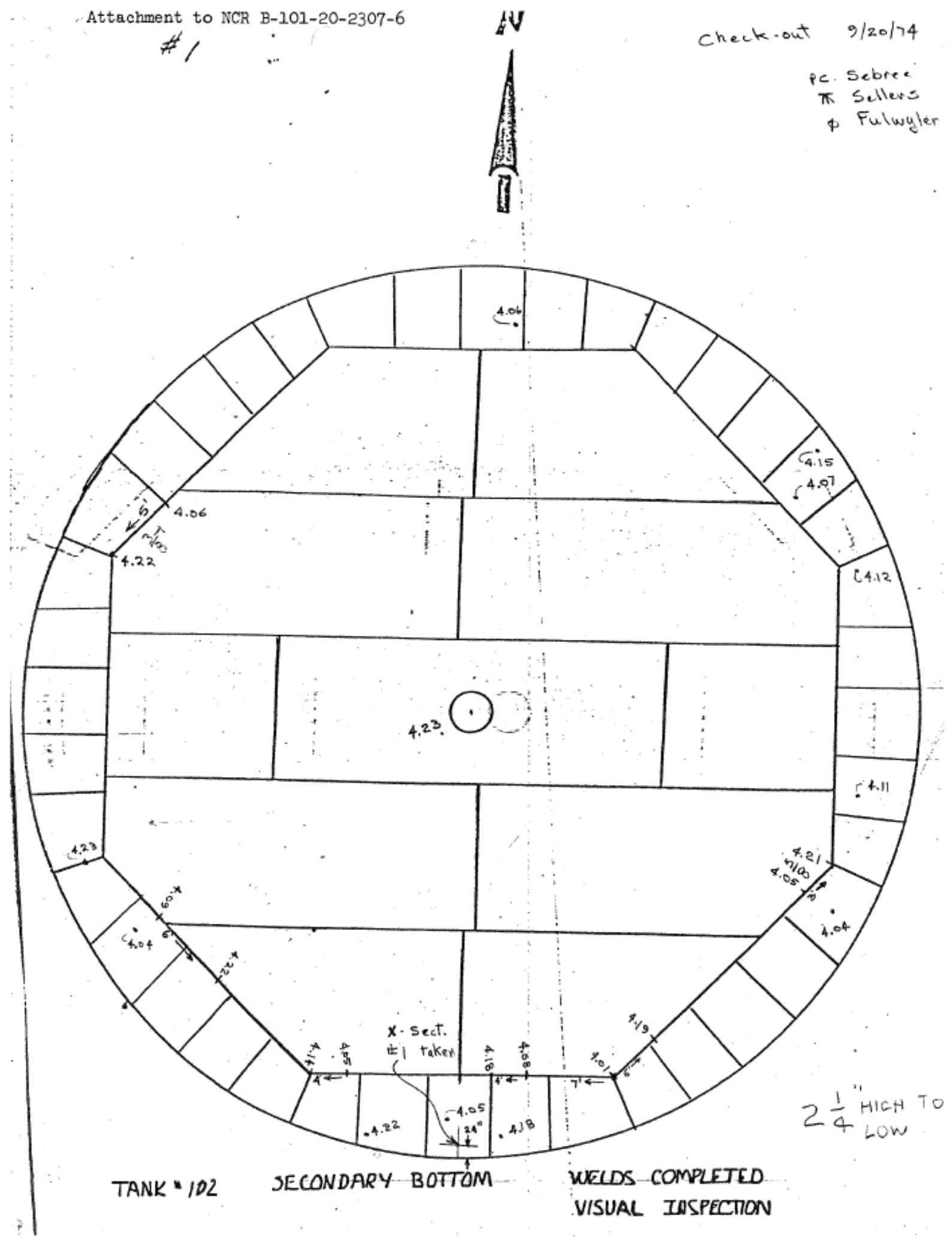


RPP-RPT-54819, Rev. 0

ATTACHMENT \#6 to NCR B-101-19-2307-5, Item \#3

ATTACHMENT \#2 t NCR B-101-20-2307-6, Item \#2

ATTACHMENT \#3 to NCR B-101-21-2307-7, Item \#2

DATE: 1-10-75

(8) Verification of Action Taken: Statement of Condition of Refractory

The condition of the refractory was carefully examined prior to lowering of the Tank 102 Primary Bottom. One area (approximately $4^{\prime} \times 6^{\prime}$ ), was found to be sunken under the loading of a cribbing stack, and was subsequently repaired on February 8, 1975. The repaired area and the remainder of the foundation appeared to be in very satisfactory condition. During the examination of the refractory by E. S. Davis (Vitro) and me, small patches of ice were visible on the surface. Hammer testing of these and other areas provided no indication of frozen or defective material. Minor cracks were noted over the air supply piping and around other cribbing stacks, but were not considered detrimental. Thus, I informed J. E. Parsons (JAJ) and M. J. Fatur (ARHCO) that the condition was considered satisfactory, and that lowering may commence.

For historicel purposes, it appears at this time that the product used for the refractory foundation may contain superior qualities with respect to cold weather tolerance than those previously experienced. 
RPP-RPT-54819, Rev. 0

App Figure C-5. NCR B-101-21-2307-7, 241-SY Tank Farm Salt Cake Storage Facilities

NONCONFORMANCE REPORT

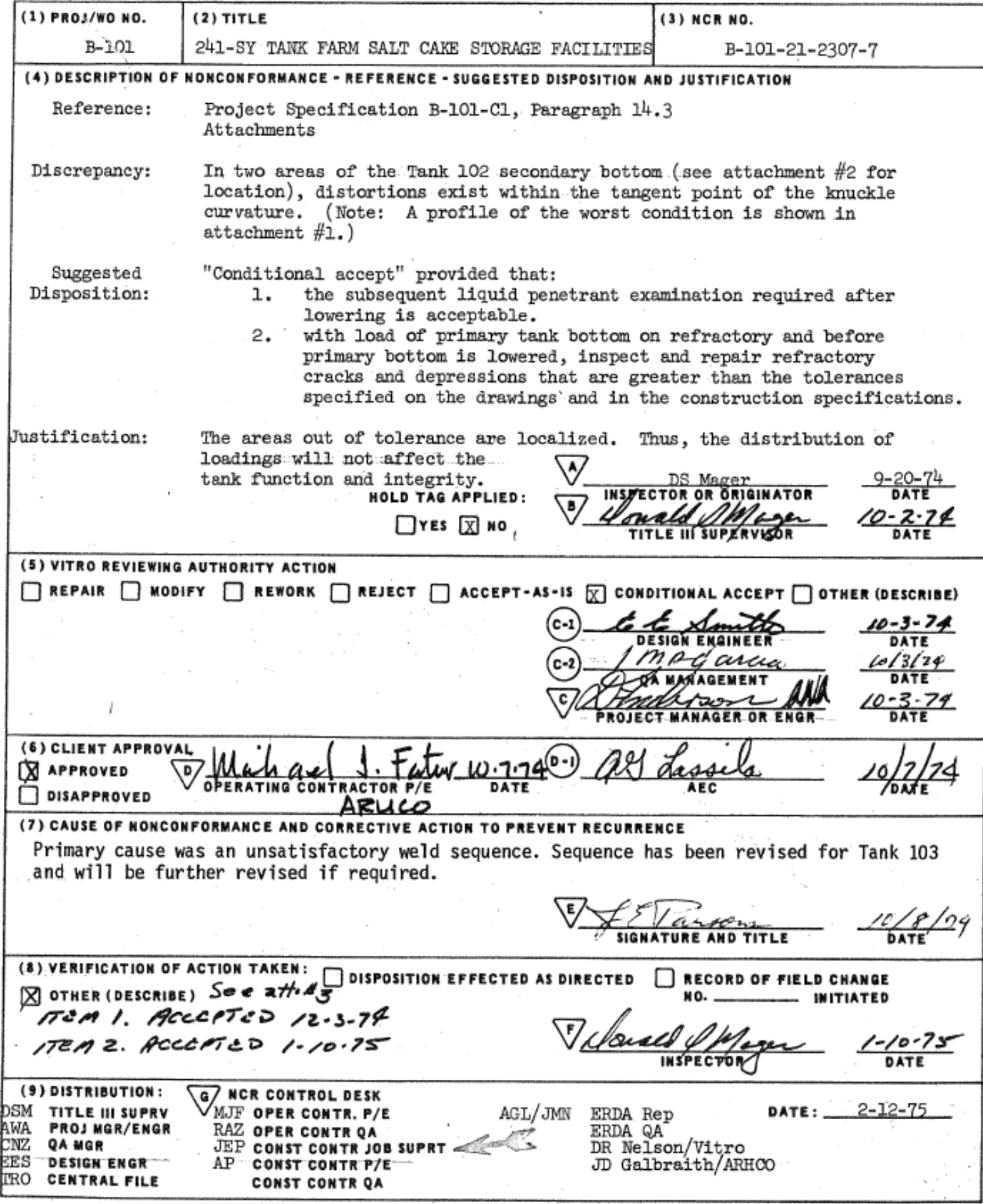


RPP-RPT-54819, Rev. 0

ATTACHMENT in, to ..'R B-101-21-2307-7

DISTORTION AREA "A"-PROFILE
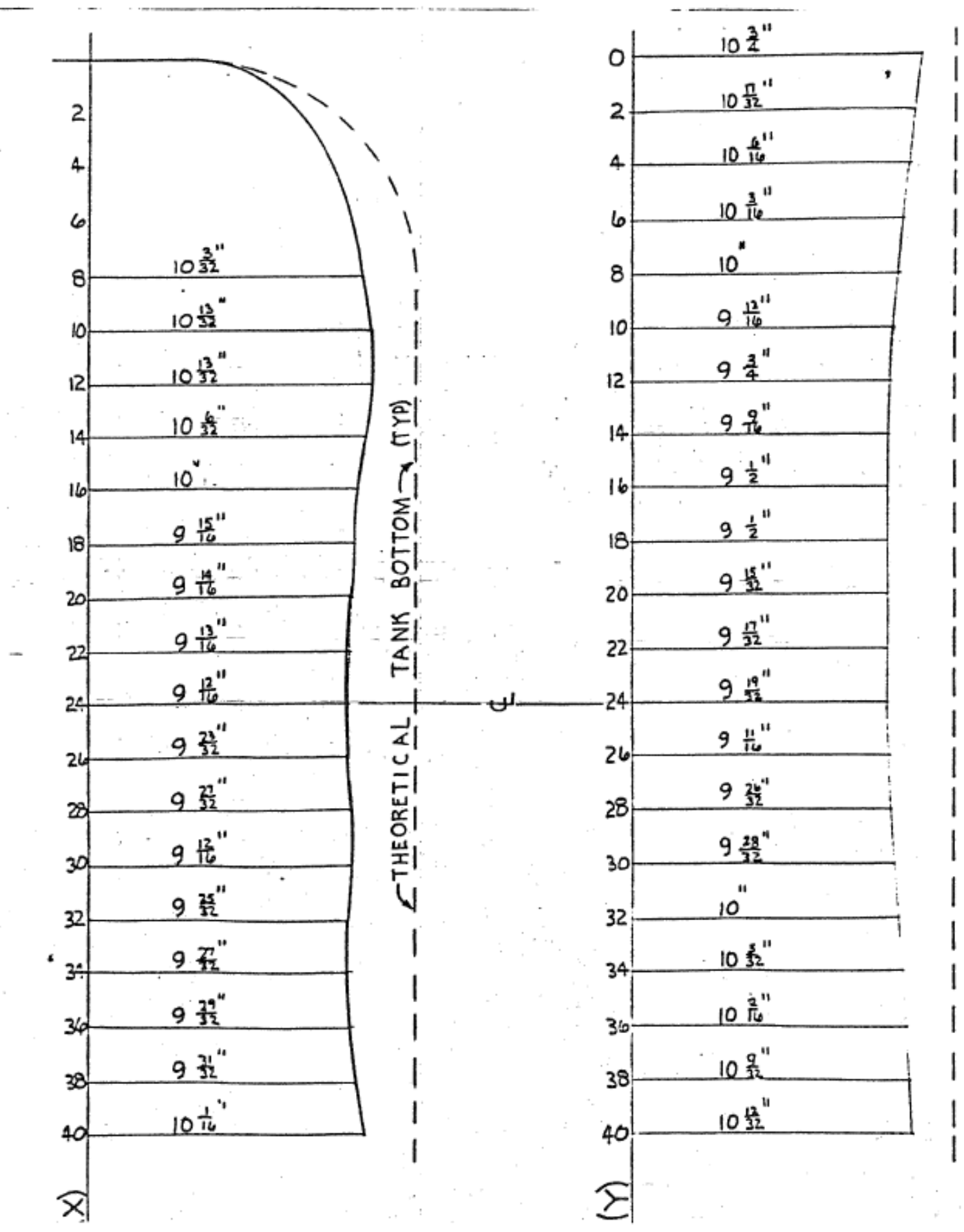
RPP-RPT-54819, Rev. 0

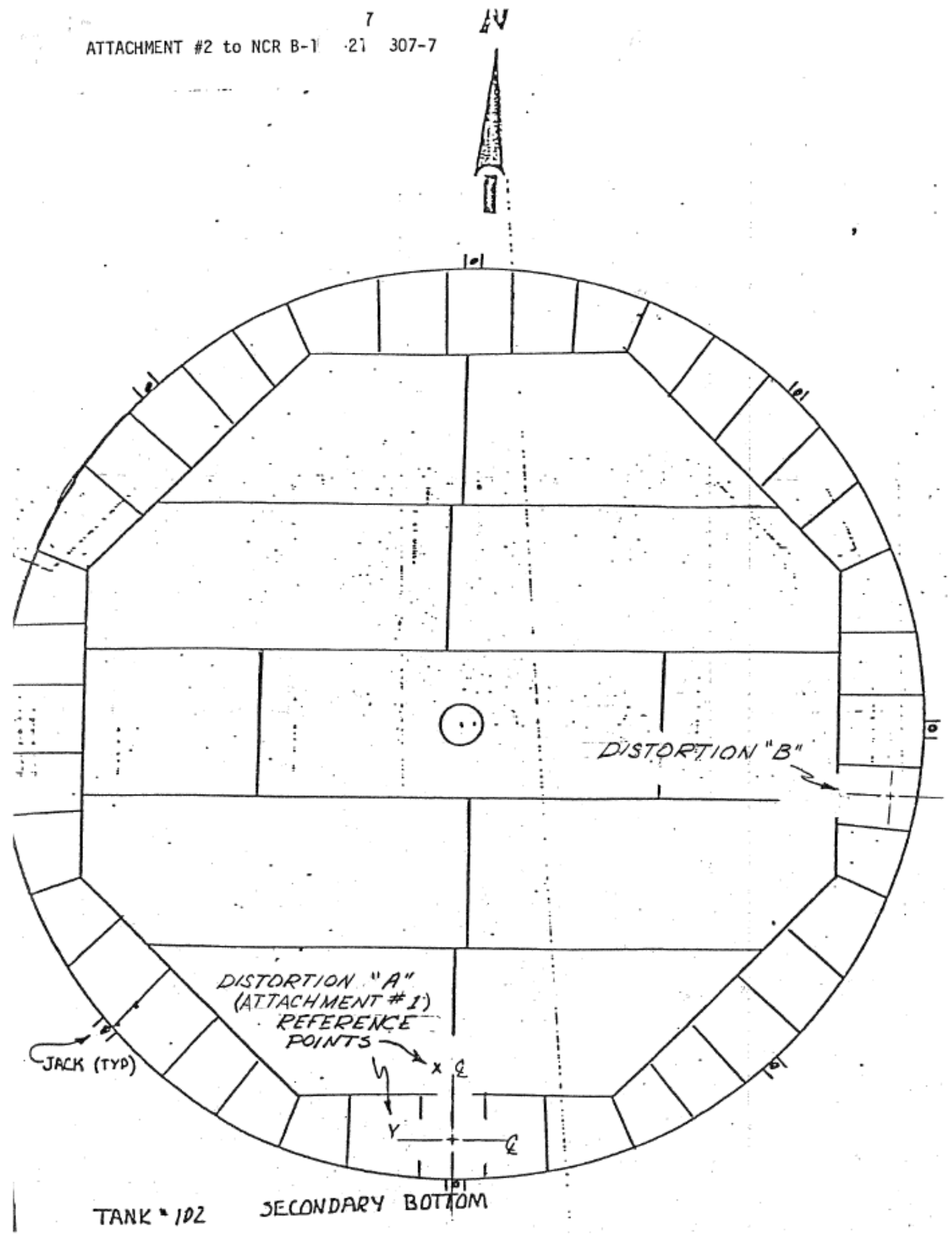


App Figure C-6. NCR B-101-24-2307-9, 241-SY Tank Farm Salt Cake Storage Facilites
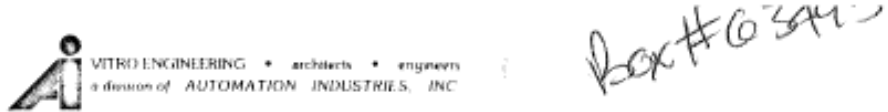

NONCONFORMANCE REPORT

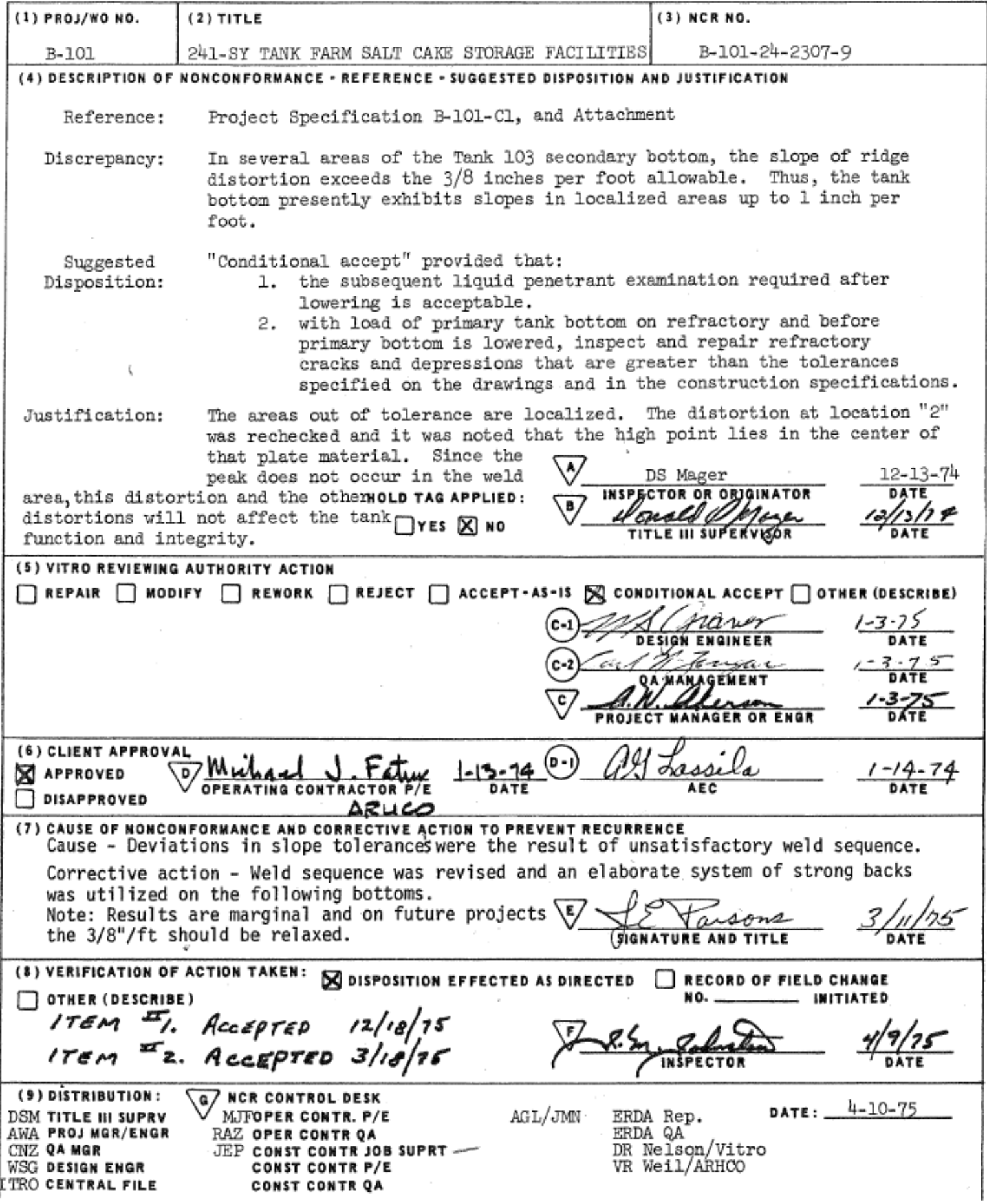


RPP-RPT-54819, Rev. 0

ATTACHMENT TO NCR B-101-24-2307-9

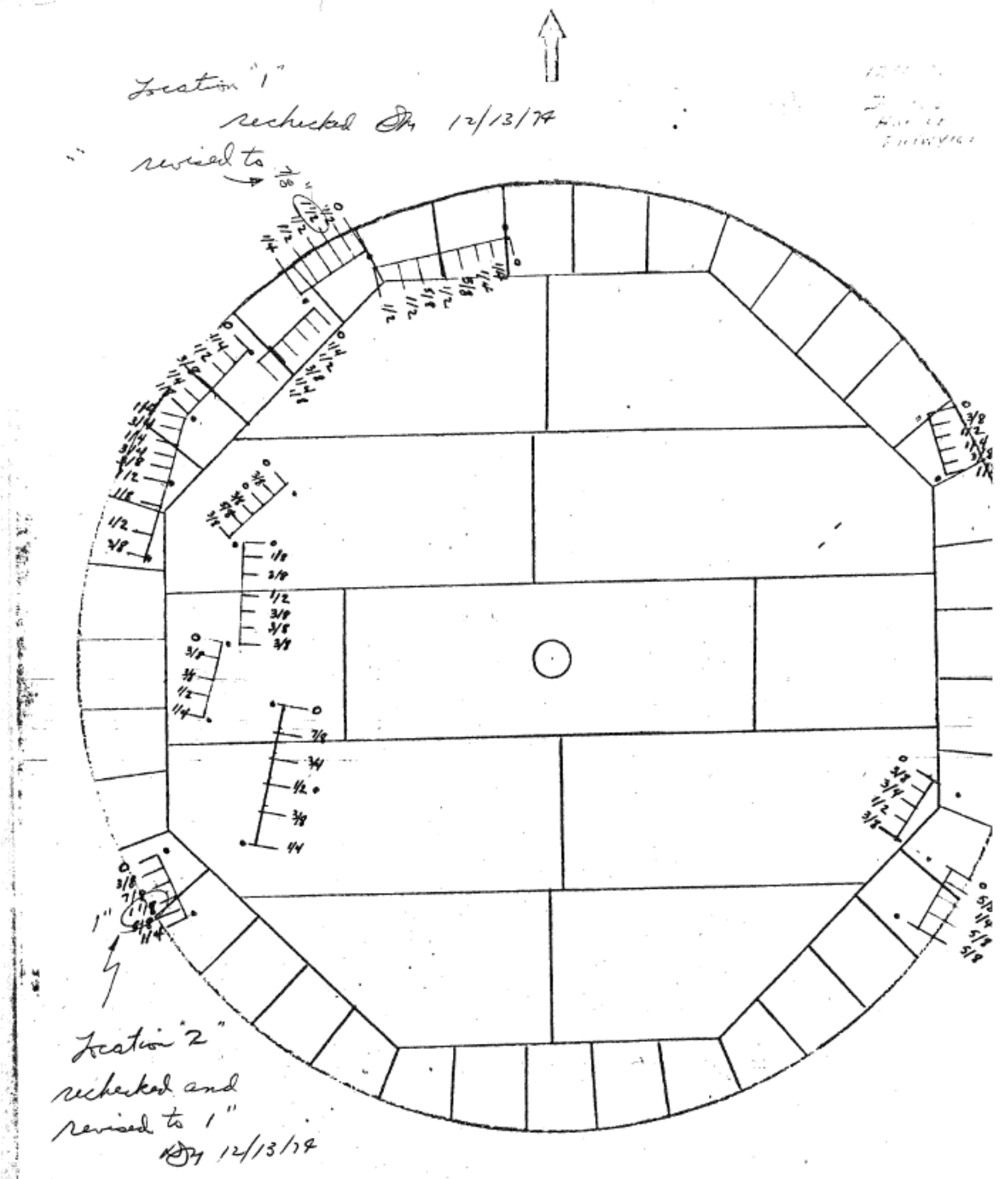




\section{App Figure C-7. Oct 1, 1975 Letter to J.F. Albaugh}

\section{Atlantic Richfield Hanford Company}

October 1, 1975

To: J. F. Albaugh

From: J. D. Galbraith, 2-2382

Subject: DOCUMENTATION OF VERIFICATION OF

SY TANK FARM TANK BOTTOM FLATNESS

As per your request I have reviewed the Vitro documentation that verifies that the 101 and 102 primary tank bottoms do comply with the construction specification. Vitro Title III is in compliance with their approved Title III Inspection plan and with the approved Construction Specification (B-101-C1).

Upon review of the documentation that Vitro Title III did have on file, it was found that there were no outstanding NCR's on the 101 or 102 primary tank bottoms. All of the records that Vitro had committed themselves to generate were in place and did have the acceptance signature of an authorized Title III Inspector.

During the review of the documents pertaining to the fabricated condition of the 101 and 102 tank bottoms, a Survey Report was reviewed that indicated that the 101 tank bottom was not in compliance with the Construction Specification. After further investigation of this indication, a Deficiency Report (\#21), which was generated by CB\&I confirmed this condition. This condition was found before the primary tank bottom had been lowered into its final position on the insulating concrete. The deficiency report was initiated on February 14, 1975 which is also the date that Vitro Title III surveyed the tank bottom. The area that was identified as not being in tolerance was then re-worked and the deficiency report was signed off by Richard.Ford (CB\&IQC) on April 28, 1975 as being resolved by re-working. It should be noted that no further documentation was generated to establish the slope of this area after re-work. On March 3, 1975 the 101 primary tank bottom was lowered into position and on March 4, 1975 Vitro Title III Inspection signed off on their Summary Checklist that the 101 primary tank bottom did comply with the flatness requirements as specified in the B-101-Cl Construction Specification.

The main item of interest that was found during this review was that the mode of inspection for flatness was not the same for the 101 tank as the inspection for the 102 and 103 tanks. 
RPP-RPT-54819, Rev. 0

\section{Atlantic Richfield Hanford Company}

J. F. Albaugh

Page 2

October 1, 1975

Surveys of the 102 and 103 bottoms were made after lowering, but on the 101 tank no survey was made after lowering.

The consistancy of documentation of inspection is therefore somewhat questionable for the 101 tank bottom. It should be noted that there is not any requirement in the Construction Specification or Vitro Title III Inspection plan which establishes that a survey will be made of the primary tank bottoms for flatness. Vitro Title III does state in their inspection plan that they will do what is necessary to verify the dimensional requirements of the tank bottoms, which in this case was a visual examination of the 101 primary tank bottom.

$J D G: f d$

CC: JD Galbraith

AG Lassila

D Schrag

VR Weil

AT White

RA Zinsli

ERDA-RL, QA 


\section{App Figure C-8. May 4, 1976 Letter to V.D. Schrag}

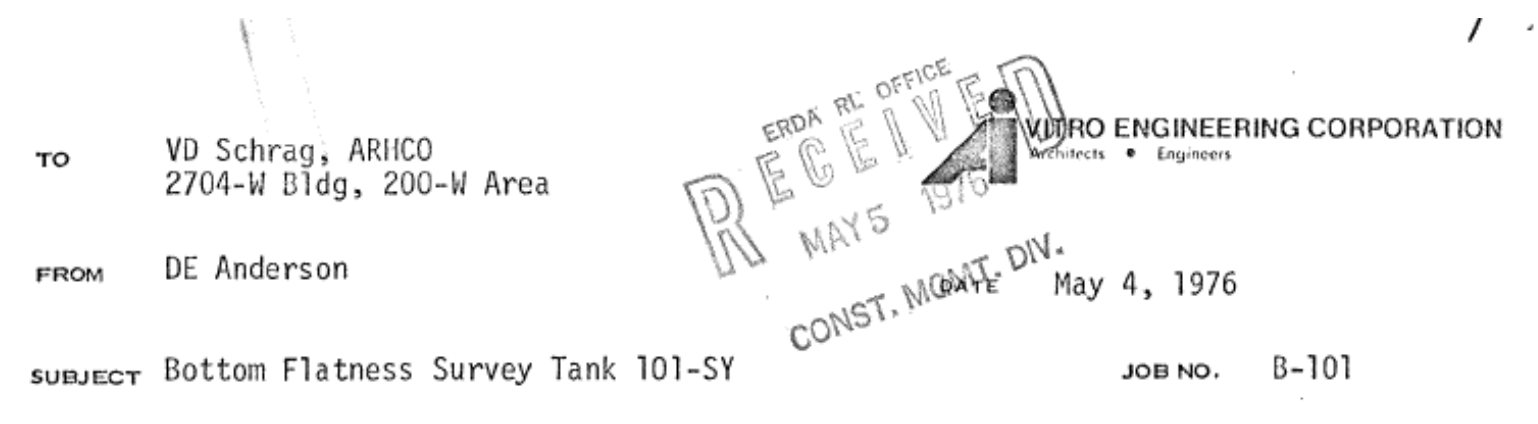

The survey requested for the 101-SY primary tank bottom was completed on 4-22-76. The rod readings and plot of the maximum bump are as shown on the engineering sketch attached (ES-B101-M6).

The purpose of the survey was to check the tank bottom for flatness since it was the only remaining tank of the three that was not checked after stress relieving following the flatness problem associated with Tank 103 . The 101 primary bottom was checked prior to being lowered onto the refractory and one area around the weld T-joint approximately $20 \mathrm{ft}$ south of the tank center on the north-south axis exceeded the $3 / 8^{\prime \prime} / \mathrm{ft}$ slope tolerance. The area was cut open and rewelded to bring the slope in tolerance. The primary bottom was lowered onto the refractory and checked for flatness using a carpenter's level and rule. Ho slopes in excess of the specified limit were found and the bottom was accepted and signed off by the inspector on the inspection check 1ist. No survey data was recorded as there was nû nonconforming condition to report. The change in bottom configuration is believed to have been caused by subsequent loading imposed on the knuckle during construction, especially during stress relieving.

The maximum bump height is $0.26 \mathrm{ft}$ as opposed to the $0.25 \mathrm{ft}$ reported previously following our preliminary survey of 4-5-76. The maximum slope is $0.07 \mathrm{ft} / \mathrm{ft}$ or approximately $27 / 32 \mathrm{inches} / \mathrm{ft}$. There was $2-1 / 2$ to 3 inches of water in the tank when the 4-5-76 survey was taken. The water level was reduced approximately 2 inches, prior to the $4-22-76$ survey. There were some ininor elevation differences noted between the two surveys at the same tank bottom location. For example, the maximum high to low increased from $0.25 \mathrm{ft}$ to $0.26 \mathrm{ft}$, and the center of the tank was 0.02 $\mathrm{ft}$ higher and dry on 4-22-76. The maximum gap between tank bottom and the refractory is believed to be about $2-1 / 2$ inches. The primary knuckle is depressea into the refractory at the tancent point and the maximum difference in bottom elevation at the knuckle tangent is $1 / 2$ inch. The tolerance on the supporting refractory is plus or minus $1 / 4$ inch from level so variations in elevation at the support surface can account for a $1 / 2$ inch elevation difference in the primary tank bottom.

The maximum bump in Tank 101 is similar to the bump in Tank 103 that was subjected to extensive studies previously. Based on the 103 tank 
VD Schrag, ARHCO

May 4, 1976

Page 2

bottom flatness studies, we do not believe that the burips in Tank 101 will compromise the integrity of the tank beyond that which would be experienced if the 101 tank bottom were free of bumps. It is our understanding that BNW is of the opinion that all bumps should be evaluated on a case-by-case basis. We reconmend that BWW be engaged to evaluate the 101 survey attached to resolve any potential issue and hopefully establish some truisms applicable to bumps in general, somewhat similar to the bottom flatness tolerances they have developed for ARHCO. He would prefer to direct BNW in this effort; however, we are primarily concerned with obtaining analyses that will verify our belief regarding the 101 tank bottom, and that is applicable to future tanks. We request your concurrence and/or direction regarding our recommendation.

DEA:mm

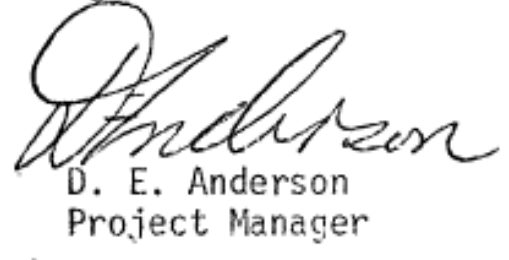

Enc. As stated

cc: AG Lassila, ERDA

JM Nelon, ERDA

RP Saget, ERDA.

JF Albaugh, ARHCO

RC Roal, ARHCO

HA Zweifel, ARHCO

SS Compton

DRN/DEA-file

JF Nelson/ESD

EE Smith (2)

RR Wyer

Central File

DS Mager

LB 
RPP-RPT-54819, Rev. 0

\section{App Figure C-9. Record of Design/Field Change B-101-128, 241-SY Tank Farm Salt Cake Storage} Facilities

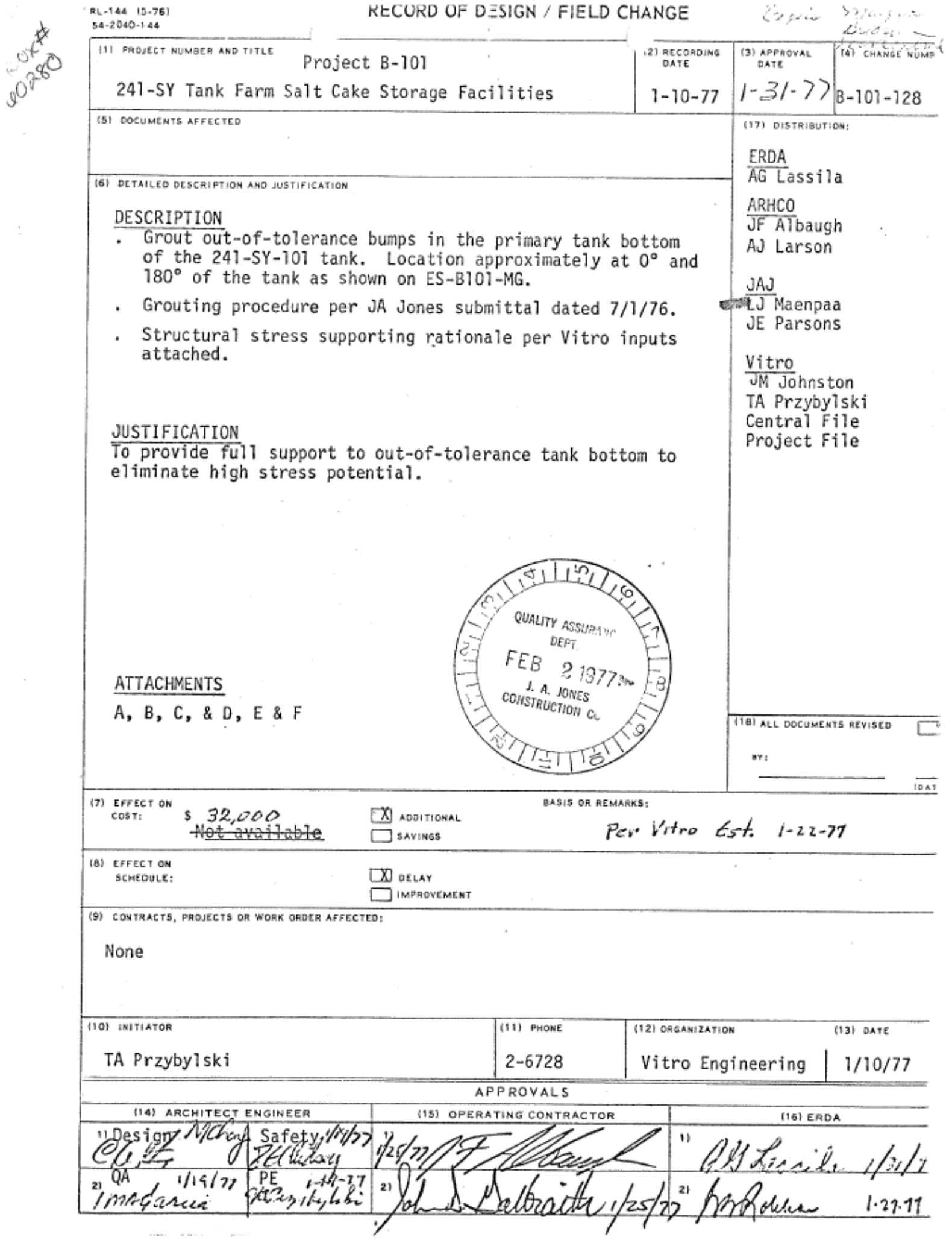


RPP-RPT-54819, Rev. 0

STRUCTURAL INTEGRITY PLAN AND ANALYSIS RESULTS

FOR

DESIGN FIELD CHANGE B-101-128

Preliminary stress analysis (phase I) for the proposed Design Field Change (B-101-128) for the support of the 241-SY-101 primary tank bottom anomalies.

I. Analysis

A. Loads

a. Dead Load (D) - primary steel weight

b. Live Load $(L)$ - Liquid weight (specific gravity = 1.7)

c. Pressures (H.S.) - Liquid static pressure and vapor pressure.

d. Thermal - Creep ioad $(T)$ from concrete dome - used same as B-120

e. Thermal - growth load $(T)$ assumed primary tank-under $30^{\prime}-3^{\prime \prime}$ liquid level $=250^{\circ} \mathrm{F}$; above $30^{\prime}-3^{\prime \prime}=210^{\circ} \mathrm{F}$

\section{B. Mathematical Model}

The out-of-tolerance bumps in the bottom of the tank is a threedimensional and non-axisymmetric problem with axisymetric load. A two-phase analysis for the project is being accomplished for cost effectiveness and to meet time requirements. The first phase (completed) was to analyze an axisymmetric model (see Fig. 1) with combining axisymmetric load from Item I. The 147 gap elements (stiff 12 from ANSYS) for the boundary condition in the bottom of the tank were used to make an analogy with actual behavior of the bottom tank. The 207 axisymmetric conical shell elements (stiff 11 from ANSYS) were used to represent the primary tank. The second phase is to make and analyze a three-dimensional mathematical model (see Fig. 2) with gap element at the bottom of tank by using an edge boundary condition. These conditions were derived from the first phase and considered to be of no effect in the stress distribution of critical regions (elements 218-234-235, 91-100-101 Fig. 2 using ANSYS computer program). The analysis considers the resistance of bump due to thermal growth.

The friction coefficient is assumed to be 0.1 .

II. Results from Phase I

The maximum wet compressive stress in the bottom of the tank from Phase $i$ study is 18.9 ksi (allowable stress for $D+L+H . S .+T=$ $30.53 \mathrm{ksi}$ ). The maximum set tension stress in the bottom of the tank from phase 1 study is $4.3 \mathrm{ksi}$ - both well within limits.

The ANSYS computer analysis is printed out on RUN CMD101B dated $1 / 18 / 76$. 
RPP-RPT-54819, Rev. 0

Mulachateng o

UI UNIUI-ICO, HLL.

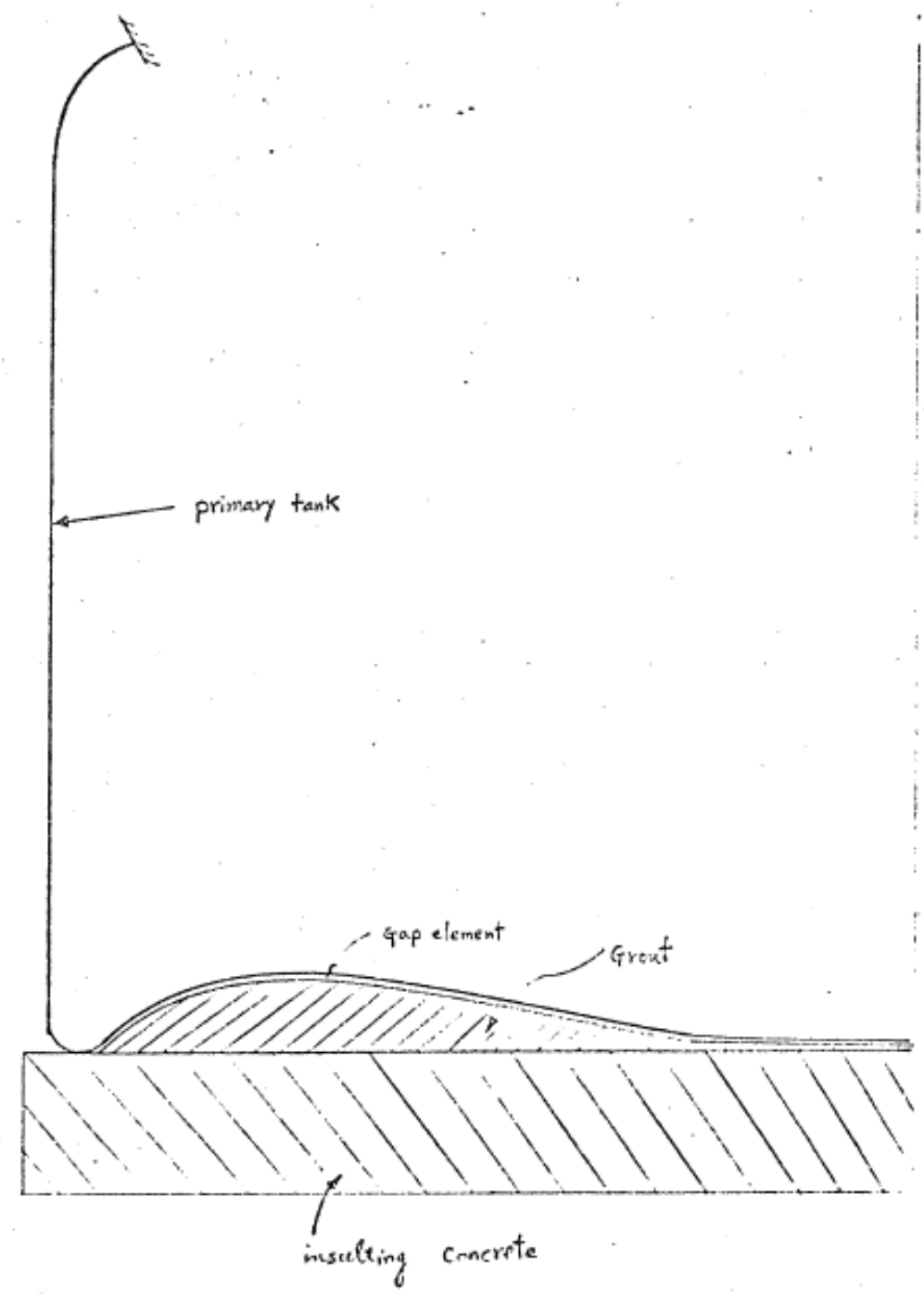

\&

FIG.I 
RPP-RPT-54819, Rev. 0

Attachment $\mathrm{C}$

Ur D-IUITiLO, HLL, 3

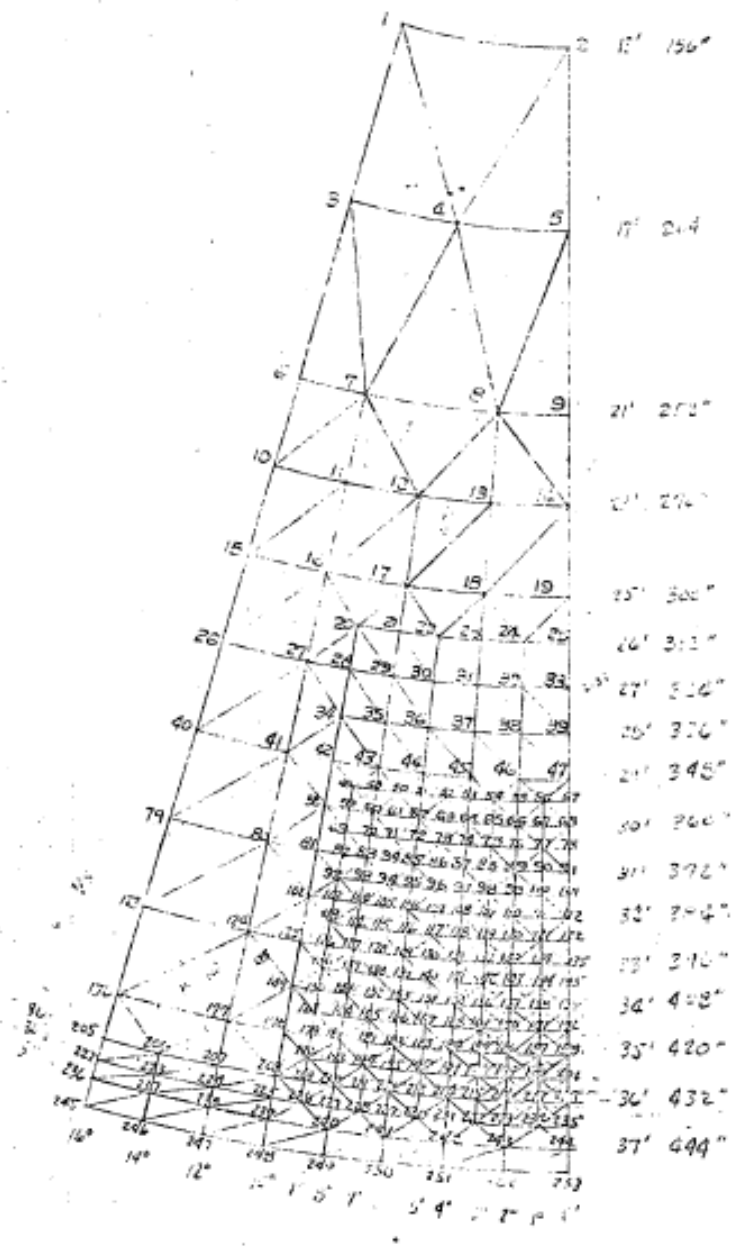

ws a d o

कर 416

142 196175

ibt $7 i c$ th

$7 c$ \& icis at?

$219 \quad 2 ?: 2 \%$

Fig. 2. 
RPP-RPT-54819, Rev. 0

Attachment D

DFC B-101-128, Att. 4

\section{TANK HEAT TRANSFER ANALYSIS}

The addition of insulating concrete to support the primary tank in the area where the tank bottom is distorted should have a negligible temperature effect.

A study of equilibrium tank temperature under normal operating conditions and then a dynamic study of thermal history upon the loss of cooling indicated a very small thermal gradient across the concrete.

With a decay heat load of 100,000 BTU per hour and with cooling air in at $90^{\circ} \mathrm{F}$ and out at $190^{\circ} \mathrm{F}$ the gradient across the insulating concrete was calculated to be $13^{\circ} \mathrm{F}$ with a primary tank temperature of $325^{\circ} \mathrm{F}$.

10,000 hours after cooling air circulation fails the primary tank temperature will reach $392^{\circ} \mathrm{F}$ and the thermal gradient across the insulating concrete reaches $17^{\circ} \mathrm{F}$.

After 100,000 hours the primary tank will reach $780^{\circ} \mathrm{F}$ and the concrete gradient, $25^{\circ} \mathrm{F}$.

These calculations are based on an 8 inch thickness of insulating concrete. The addition of one inch more would raise the concrete $\Delta T$ about $12 \%$.

Temperatures quoted above are taken from a thermal anaiys is done for project B-120. The computer run and backup calculations will be filed as backup to the $\mathrm{C} 12002$ design report in Vitro Central Files. The ANSYS analysis is printed out on Run TANKØOA dated May $\emptyset 7 / 76$. 
J. A. JONES CONSTRUCTION CONPANY PROCEDURE FOR GROUTIMG UROER

$$
\text { PROJECT B-TONK } 101
$$

SUBMITTED $7 / 1 / 76$

\section{PURPOSE}

This procedure is to outline the method used to grout under the for grouting is to give fank 101 in 241-SY Tank Farm. The reason the area defined by Drawing ES-B-101-M6.

(1) Assemble material and equipment.

(2) Check material as being light weight - 50 or 70 .

(3) Layout areas to be grouted on the outside of the primary"
tank.

(4) Cut out retainer band 2 to 3 -feet long and renove. is to be centered and 2 to 3 -feet long and remove. Cutout

(5) Chip out existing refractory a minimum of 2-feet wide 8 -inches deep and 8 -feet long. Remove broken refractory and vacuum all dust and particles from work area.

(6) Fabricate slot forms using sheet metal and install.

(7) Mix refractory per manufacture's recomendations and hand pack between existing refractory and tank bottom.

(8) Re-weld retainer band in place after minimum of 48 hours
cure on refractory.

(9) Re-clean entire area and inspect. 
RPP-RPT-54819, Rev. 0

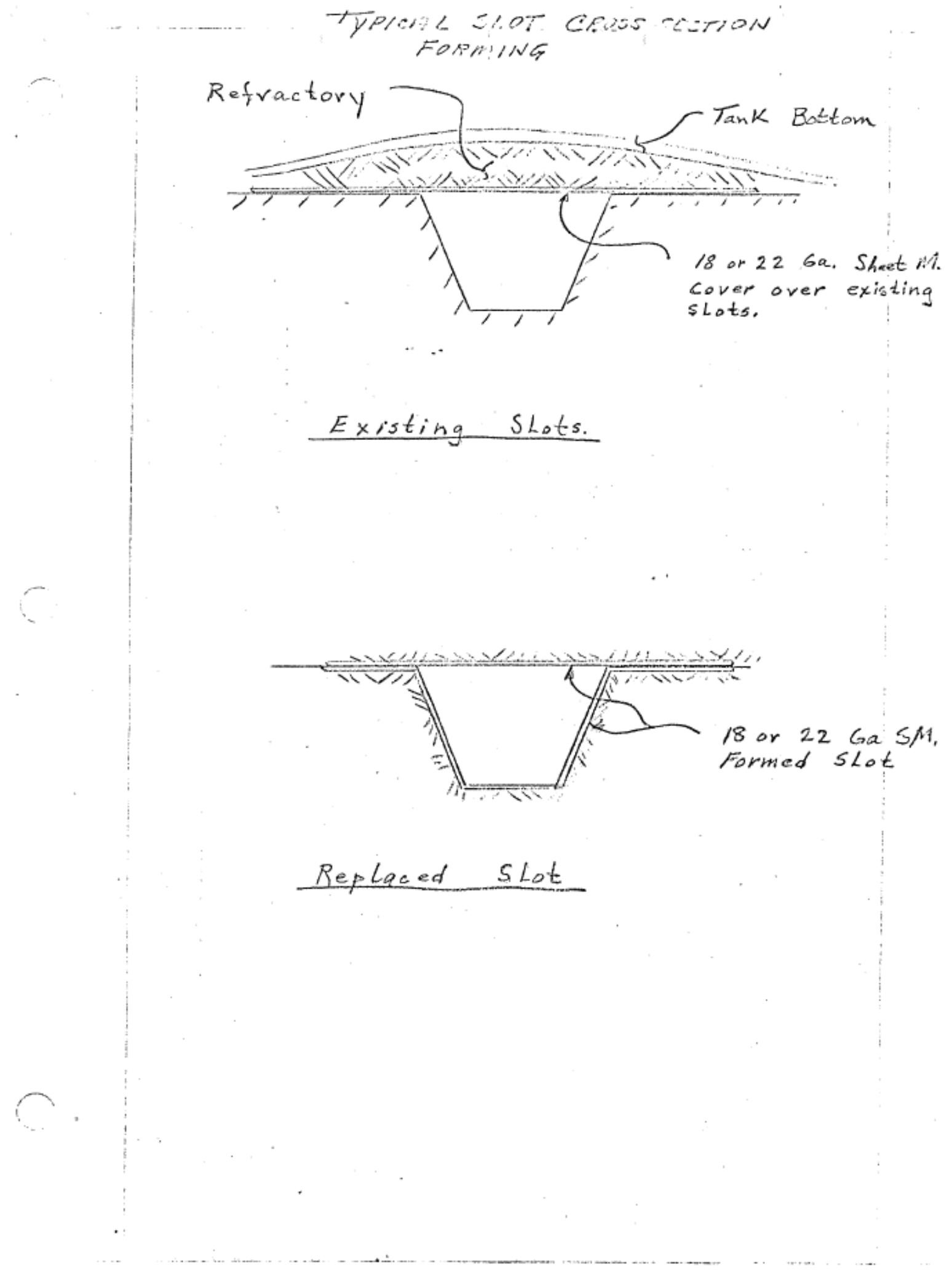


RPP-RPT-54819, Rev. 0

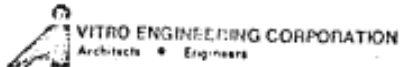

$1-22-77$

\author{
Estimate Basis \\ Primary Tank Bottom Flatness \\ - C10103
} The basis of the design field change estimate for the above mentioned
project is as follows:

1. Drawings \& Documents

a. Drawing ES-B101-M6 as developed by Vitro.

b. ARHCO's letter of instructions dated 10-22-76 addressed to AW Akerson by JF Albaugh.

2. Material Prices

Material prices for the insulating concrete were obtained from a

local contractor.

3. Labor Rates

This project was figured as a JA Jones CPAF effort. The current labor rates as published by JA Jones dated 12-20-76 were used.

4. Contingency \& Escalation

No contingency and escalation has been included in the attached estimate. It was assumed all work would be accomplished within the next 6 (six) weeks.

5. Remarks

a. No engineering costs were included in the summary of the estimate.

b. The cost of replacing the refractory under the two bumps depends on the extent of the total area involved, and this will not be known until the refractory removal has taken place. This estimate provided for the maximum area of unsupported tank bottom under the bump as indicated on the drawing times two. The actual unsupported area could be less than indicated. A cost range for this repair of $\$ 15-\$ 40$ thousand is anticipated. A contingency of approximately $20 \%$ is recommended.

JAG : mm 
RPP-RPT-54819, Rev. 0

\section{App Figure C-10. SY-101 Grout Out-of-Tolerance Distortion}

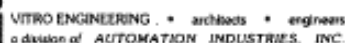

CONSTRUCTION AND INSPECTION CHECK LIST

SHEET NO. 1 OF 2

\begin{tabular}{|l}
\hline PROJECT \\
B-101 241-SY TANK FARM SALT CAKE STORAGE FACILITIES \\
DAILY CHECK LIST FOR INSPECTION OF REFRACTORY \\
REPAIR - TANK 101 \\
REFERENCE \\
RENSTRUCTION SPECIFICATION B-101-C1 \\
RERD OF DESIGN/FIELD CHANGE B-101-128 \\
OTHER DATA REPAIR AREA AT $180^{\circ}$ \\
\hline
\end{tabular}

\begin{tabular}{|c|}
\hline PREPARED BY J.M, Johnston, \\
\hline Approved By oxaly \\
\hline
\end{tabular}

DISTRIBUTION

REQUIREMENTS \begin{tabular}{c|c}
\hline ACCEPT & REJECT \\
INITIAL B DATE & INITIAL A OAT
\end{tabular}

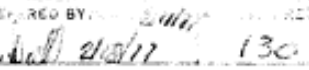

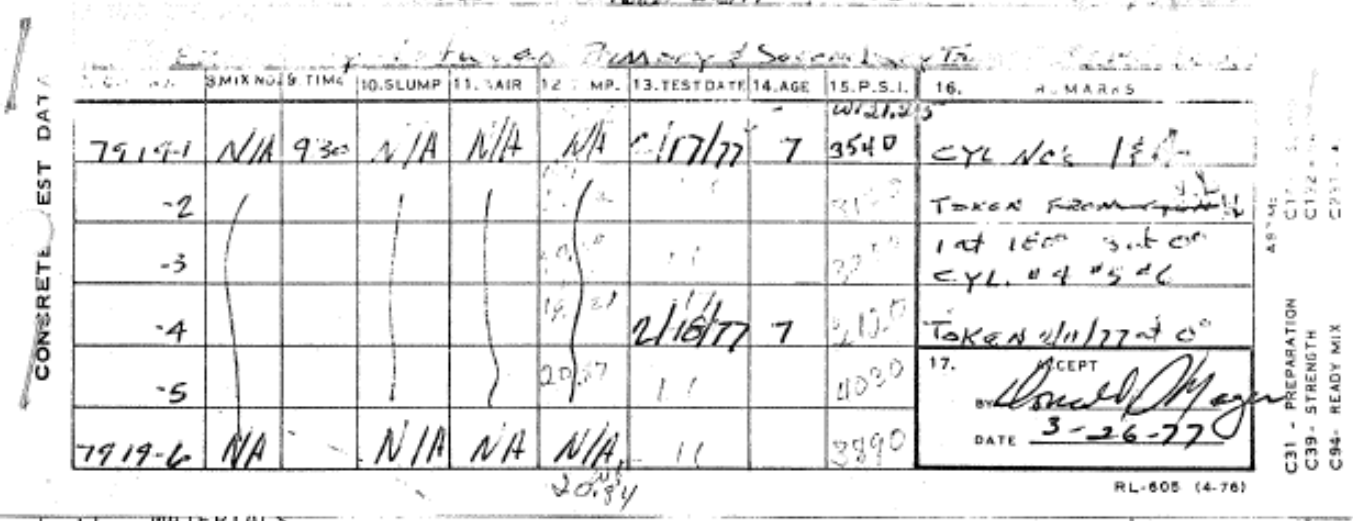

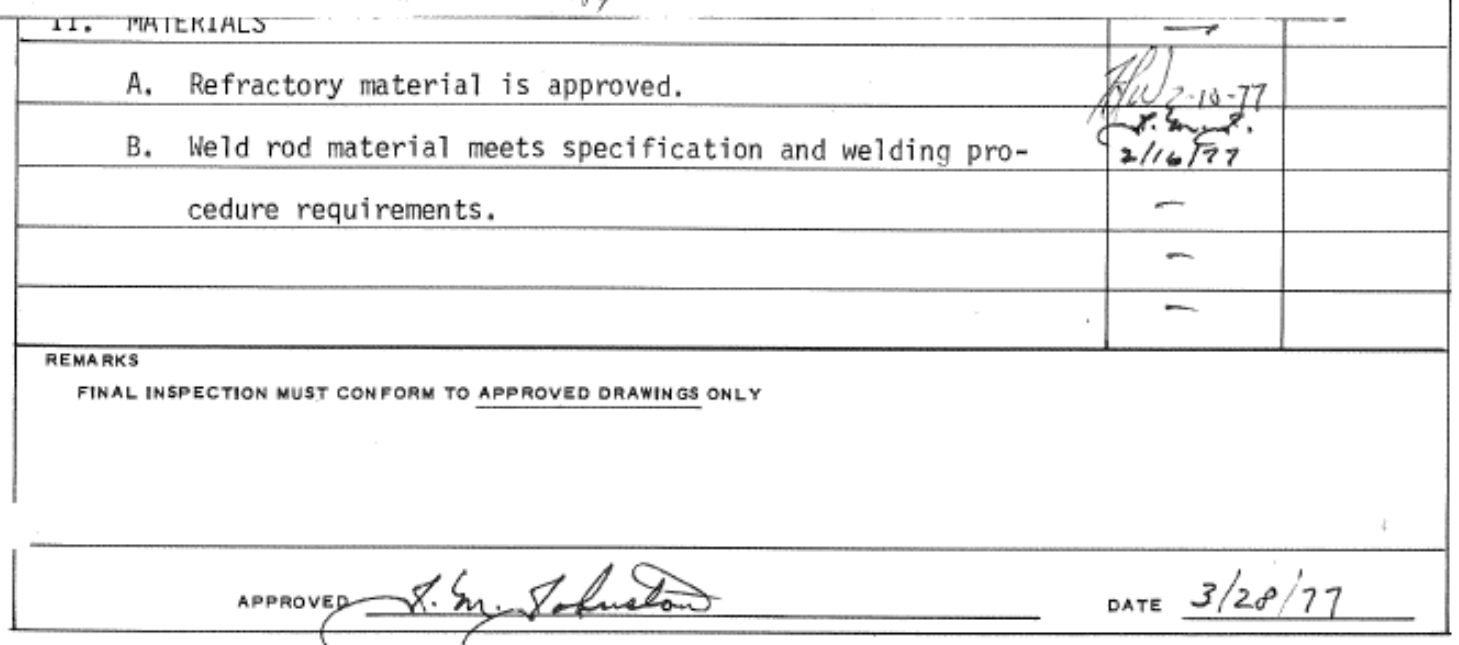

THIS FORM WILL BE USEO FOR MATE AIAL ANO EQUIPMENT RECEIPT AND ACCEPTANCE AS WELL AS CONSTRUCTION. VE-137.1 (1-75) 


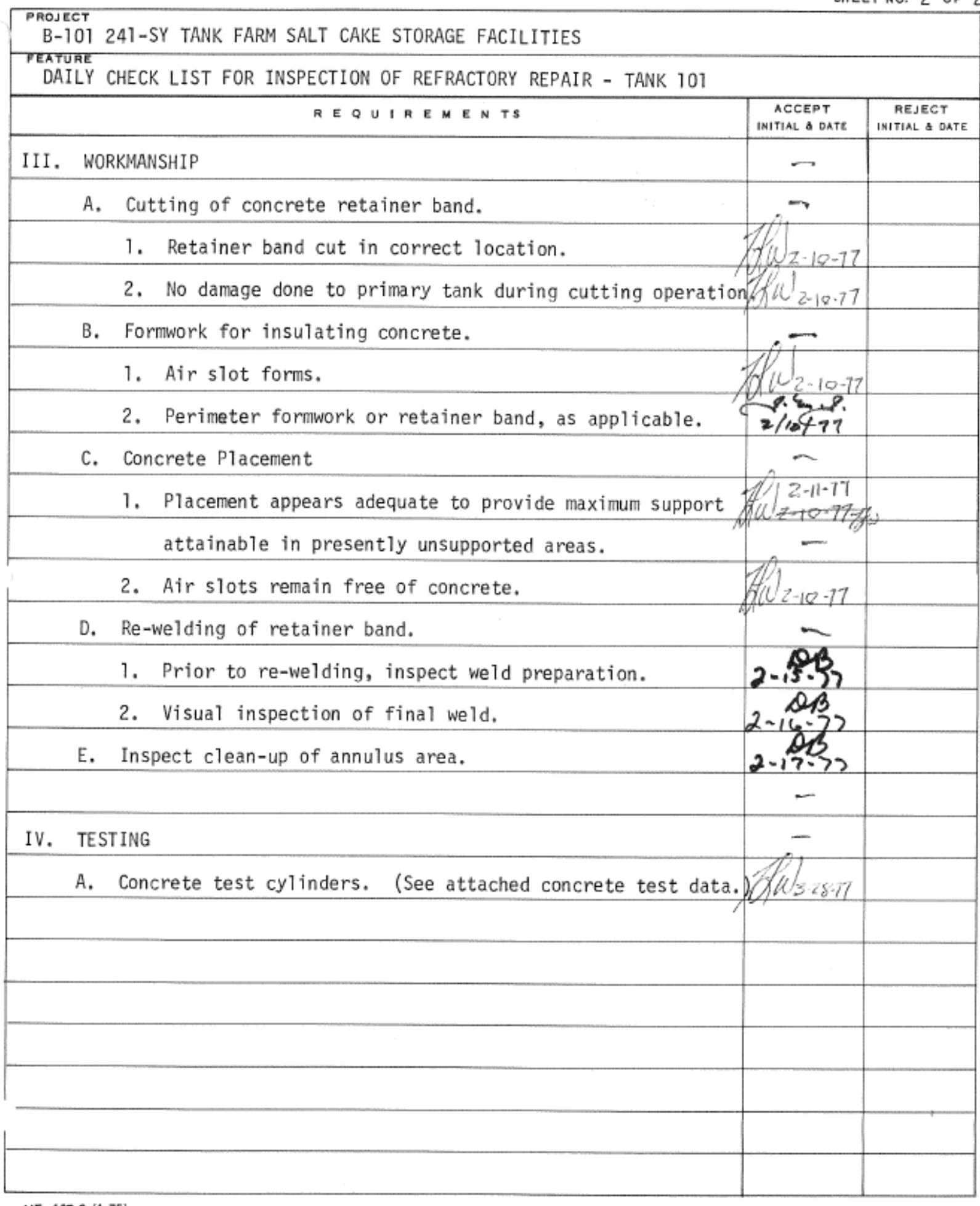


RPP-RPT-54819, Rev. 0

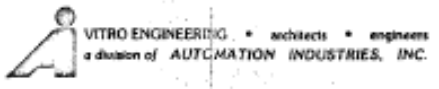

CONSTRUCTION AND INSPECTION CHECK LIST

SHEET NO. 1 OF 2

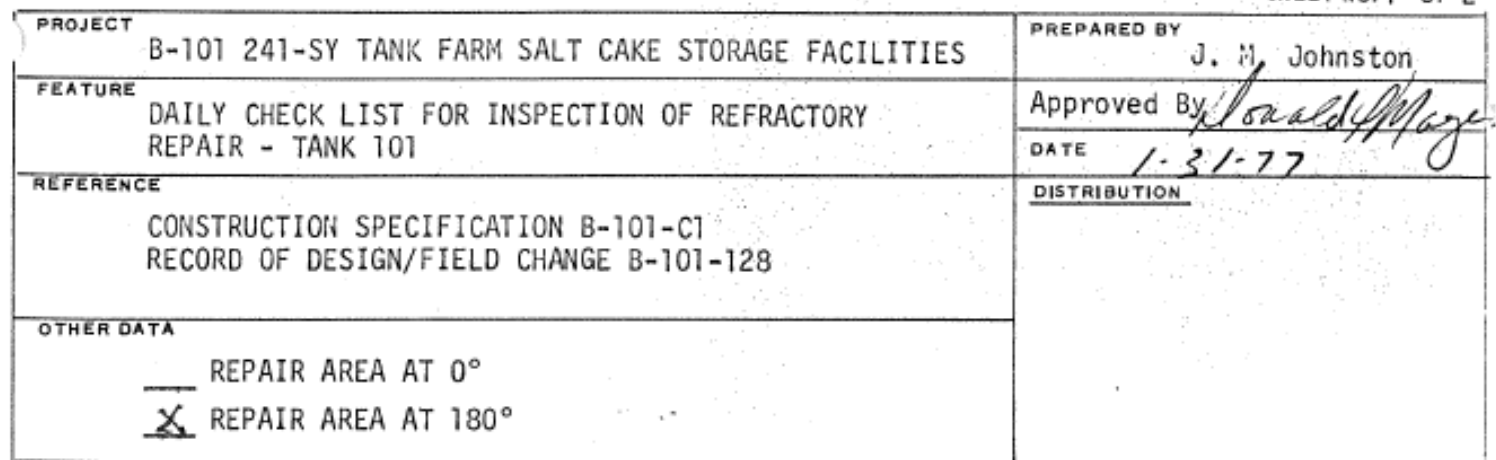

REQ UIRENENTS \begin{tabular}{c|c} 
ACCEPT & REJECT \\
INITIAL \& OATE & INITINL \& OATE
\end{tabular}

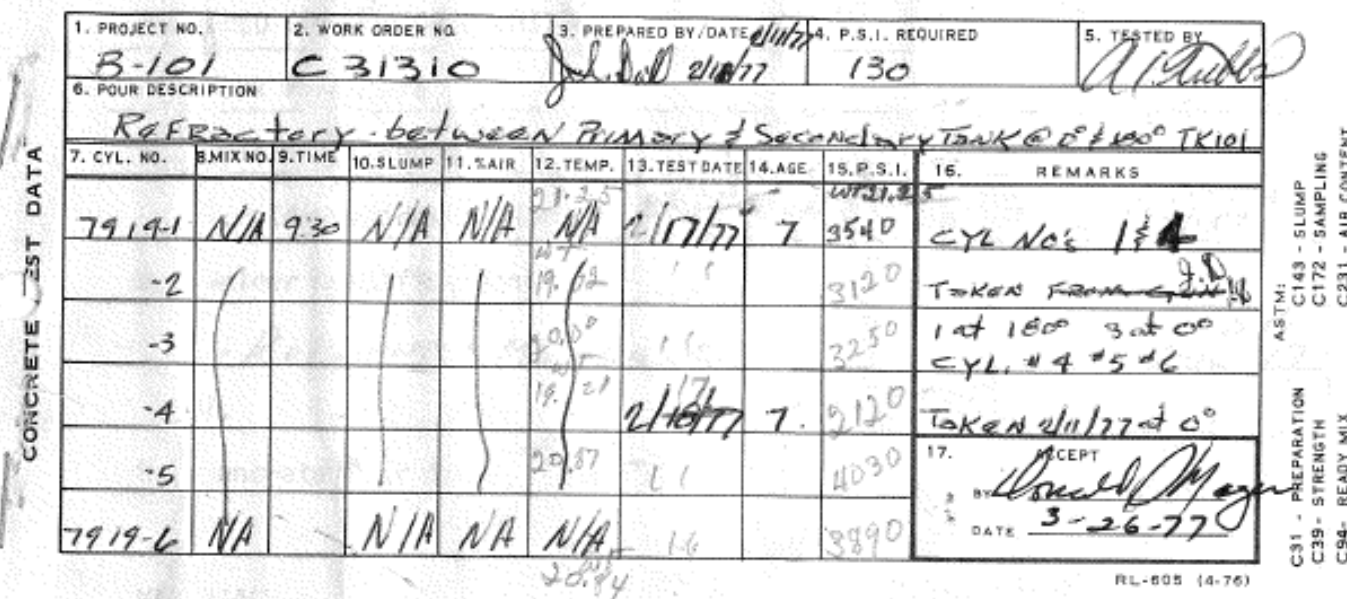

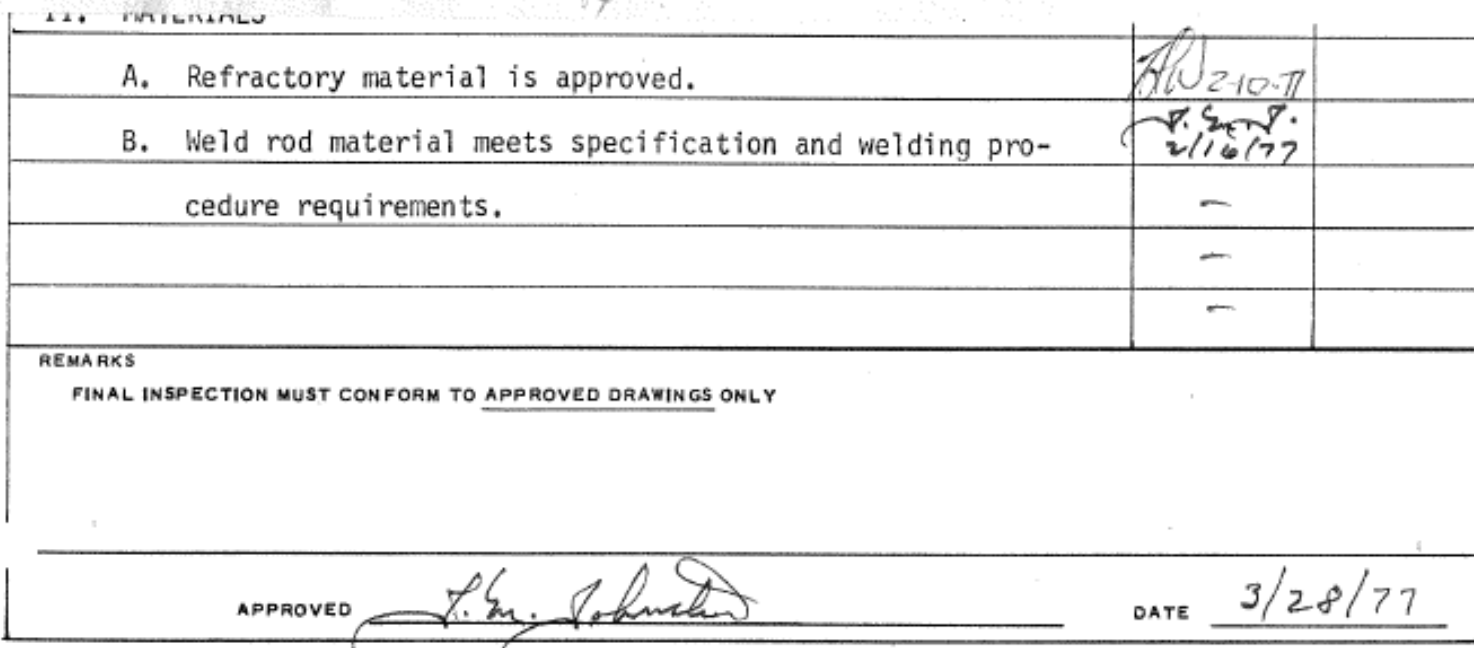

THIS FORM WILL EE USED FOR MATE RIAL AND EQUIPMENT RECEIPT AND ACCEPTANCE AS WELL AS CONSTRUCTION. VE-137.1 (1-75)

$1462 / 3 / 26$ 


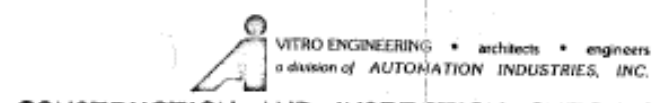

CONSTRUCTION AND INSPECTION CHECK LIST (CONTINUED)

SHEET NO. 2 OF 2

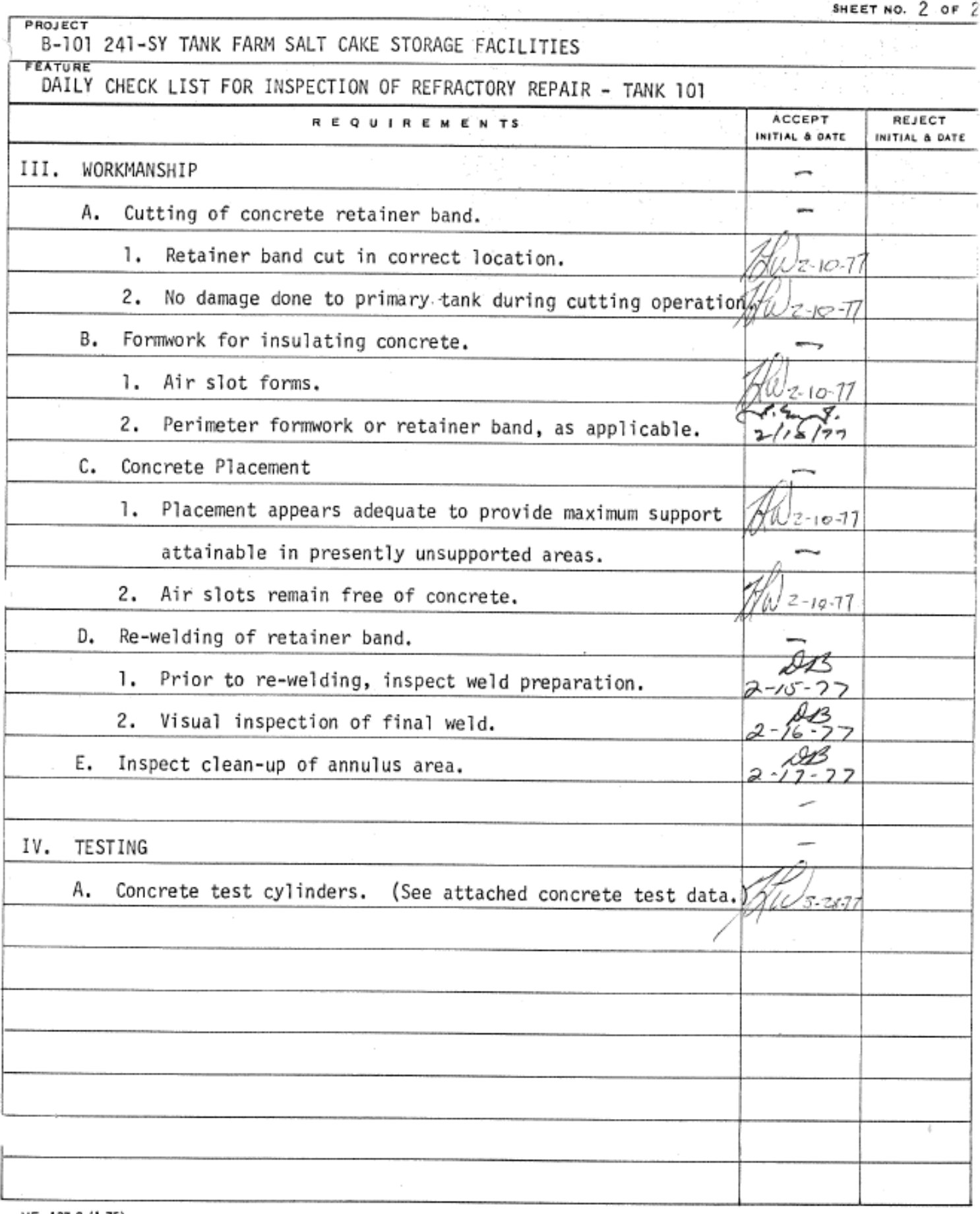

$\mathrm{VE}-137.2(1.75)$ 
RPP-RPT-54819, Rev. 0

\title{
App Figure C-11. SY-101 Grout Correspondence
}

\author{
Atlantic Richfield Hanford Company \\ Federal Building \\ Richland, Washington 99352 RECEIVED \\ Telephone 509 942.7411 \\ OCT 271976 \\ October 22, 1976 \\ VITRO \\ PRO. MQMT. \\ Vitro Engineering \\ Richland, Washington 99352 \\ Attention: Mr. A. W. Akerson \\ Subject: PROJECT B-101 - "SALT CAKE STORAGE FACTIITIES, \\ 241-SY TANK FARM" - 241-SY-101 PRTMARY TANK \\ BOTIOM FLATNESS \\ Gentlemen: \\ Please prepare a Design Field Change to initiate repair to \\ the 241-SY-101 primary tank bottom. The repair procedure \\ that has been discussed would place grout under out-of- \\ tolerance bumps in order to glve full support to the \\ primary bottom. \\ Since this change would affect the structural integrity \\ of the subject tank, the Design Field Change must be \\ accompanied by supporting rationale showing that \\ this repalr would reduce the tank plate stresses to an \\ acceptable level without having a detrimental affect on: \\ 1. Tank heat transfer \\ 2. Tank thermal growth \\ 3. Leak detection \\ Attached is Battelle Northwest, J. A. Jones Construction \\ Company, Vitro Engineering and Atlantic Richfield Hanford \\ Company correspondence on this topic.
}

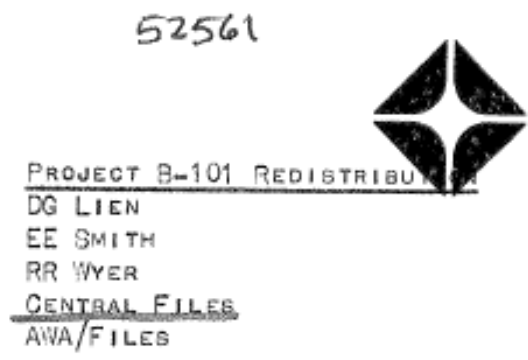

Very truly yours,

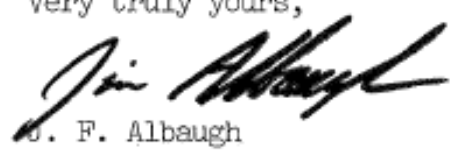

Project Engineer

JFA:sh

Att.

ce: w/att.

AG Lass1la, ERDA-RL

DD Ritter

F1le

Project File 
RPP-RPT-54819, Rev. 0

August 19,1976

5. Baftelle

Pacific Northwest Laboratories Battelle Boulevard Richland, Washington 99352 Telephone (509) 946-2702

Telex 32-6345

Mr. J. F. Albaugh

Atlantic Richfield Hanford Company

P. O. Box 250

Federal Building

Richland, WA 99352

Dear Jim:

The purpose of this letter is to document our discussions with you concerning future possible actions with regards to the SY-101 waste storage tank.

In order to put these discussions in proper perspective, a brief summary of the work that the Structures \& Mechanics Section of Battelle-Northwest has carried out for ARHCO in this area is helpful. Our first effort dealt with a detailed analysis of a somewhat idealized form of an out-of-tolerance bump in the bottom of the SY-103 tank, such work being reported in BNWL-B-475. This was followed by work which lead to the development of contour template coordinate tables which provided data for fabricating inspection templates for field use. In a related manner, we performed a generalized analysis of one class of bumps which interacted with the knuckle region in the tank. This last work was docimented in our report to you marked SAM 76-1. All the work quoted above has provided us with much insight into the tank fabrication problem and forms the basis for our present attitude on the SY-101 tank bottom question.

In our opinion, it would not be cost-effective for us, or anyone, to spend the necessarily considerable effort analyzing the actual bump configuration in great detail. If such analysis was undertaken, it is very likely to result in a conclusion that using the bumpy bottom without fixing the bumps would be unacceptably risky due to imposed, high flexural stresses during filling. Hence, some stabilizing technique, like bump grouting, would be indicated to support the flexing.

We find no difficulties associated with mechanics problems which might be imagined as a result of grouting, provided, the grout compliance and thermal properties are reasonably like that insulating concrete found under the remainder of the tank bottom 
RPP-RPT-54819, Rev. 0
J. F. Albaugh
$-2-$
August 19, 1976
(recalling that the insulating concrete has experienced thermal effects from the stress relief treatment). It does seem reasonable, however, to recommend documentation of the analysis which demonstrated such acceptability. We visualize that analysis as showing upper and lower bounds of grout properties which would be expected to perform acceptably in service.
We are prepared to assist you in the analysis of the grouting procedure and resultant structural behavior of the tank in either a direct or indirect manner. In a direct manner we would do the analysis and report the results to you. In the indirect manner we would act as consultants to the party you choose to do the work; or, as we have done in the past, act as an independent "third-party" reviewer.
If you have any questions regarding this letter, please let me know.

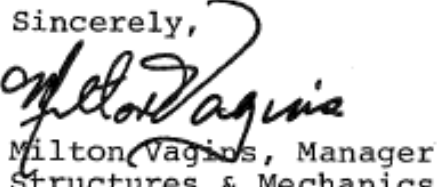
structures \& Mechanics
MV : n lm 
RPP-RPT-54819, Rev. 0

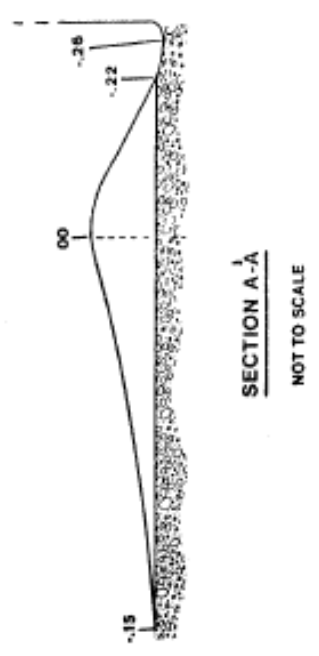

0
$\vdots$
0
5
$\frac{1}{7}$
$\frac{1}{4}$
$\frac{1}{4}$

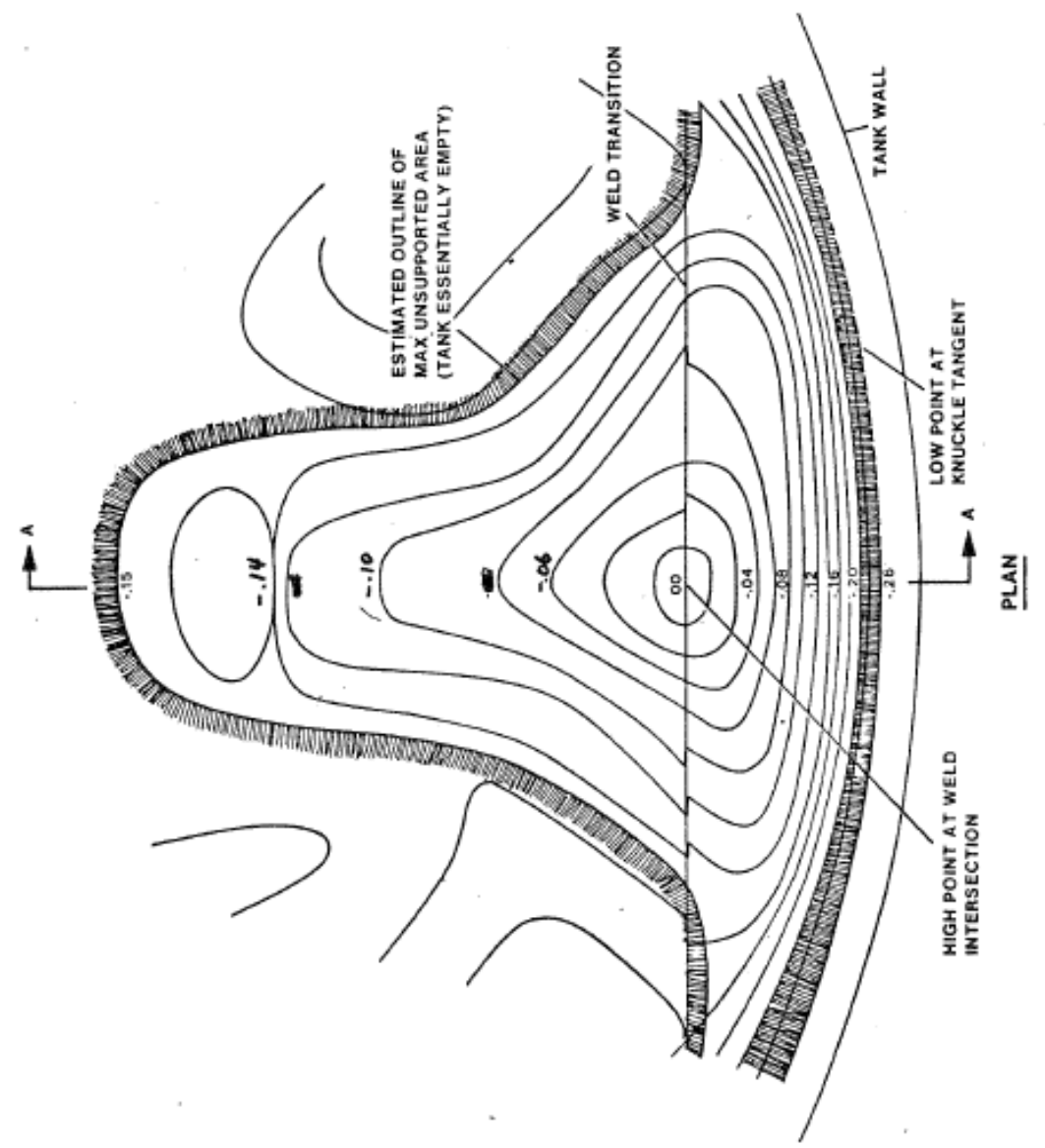


RPP-RPT-54819, Rev. 0

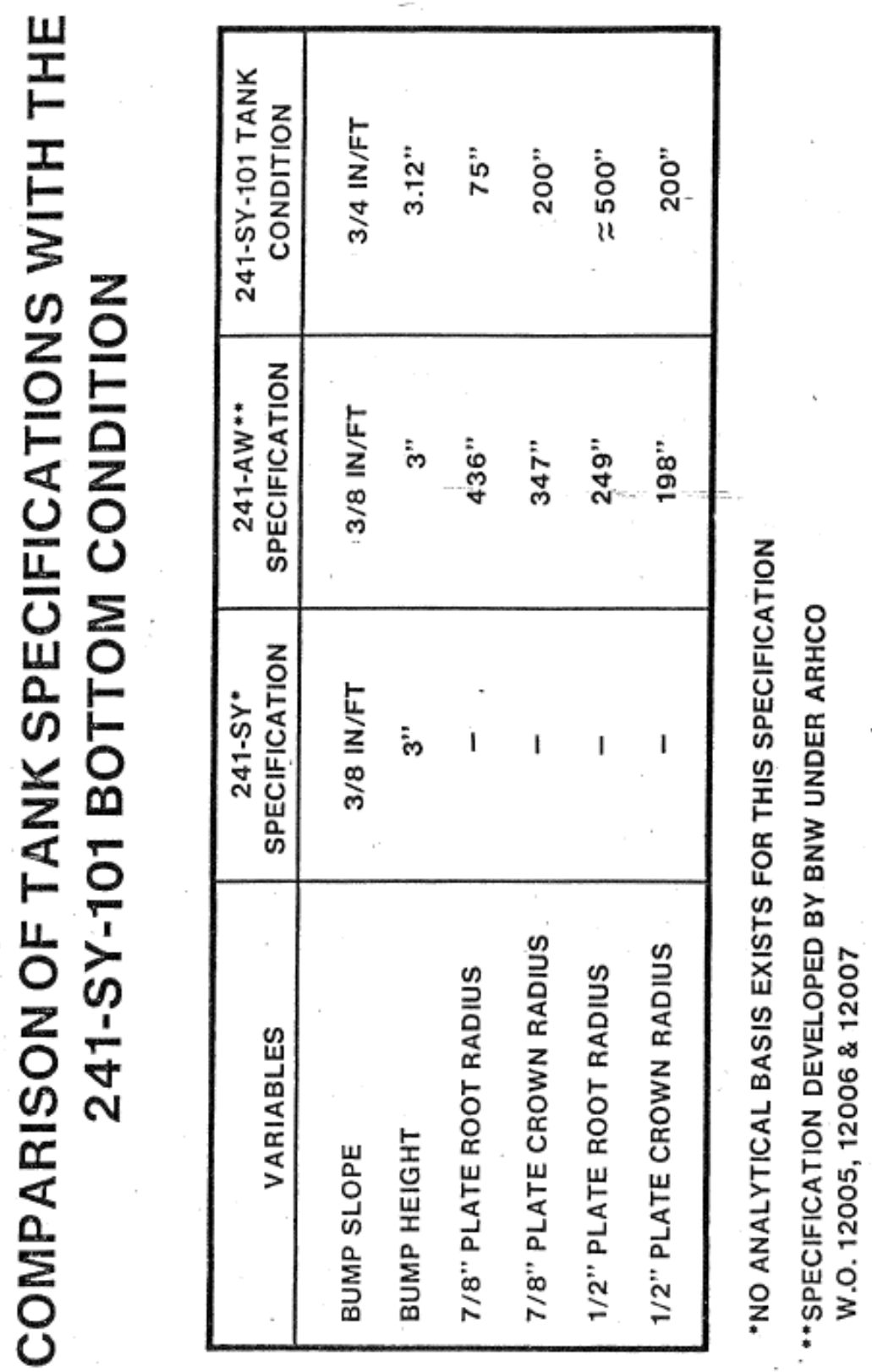


RPP-RPT-54819, Rev. 0
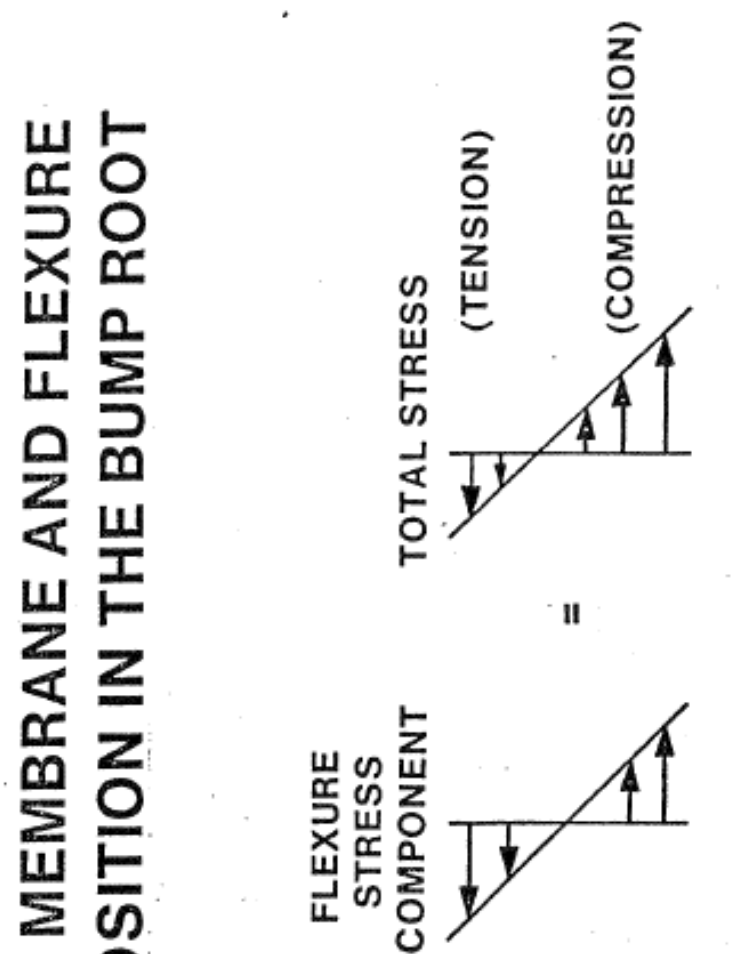

110

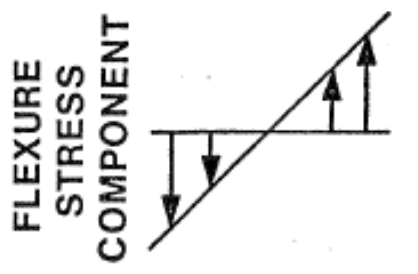

( 2

(ก)

12

U

L

แ $Z$

12

$\rightarrow 0$

2

$=0$

c

$\infty \int$

(S)

$D$
$=\frac{1}{1}$

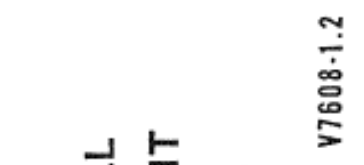

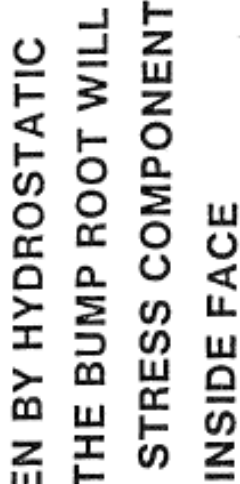

比稀

更党

므으 중

引与号

了品

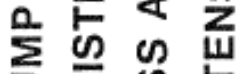

可以

ต

山 心 는

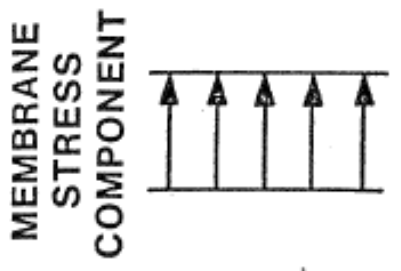

× $m$

ए

I

Z

으릴

은

号

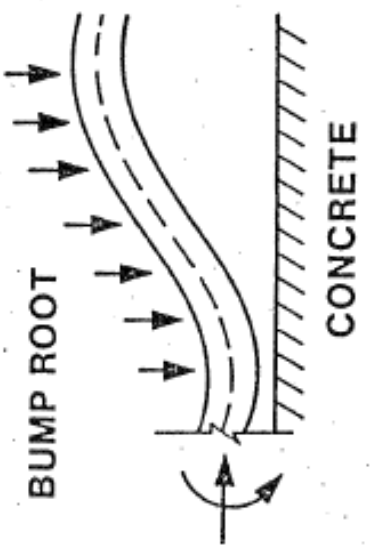

经品出

山ய

픈 음

$\propto$ 心 $\sum_{0}$

㟔

己 

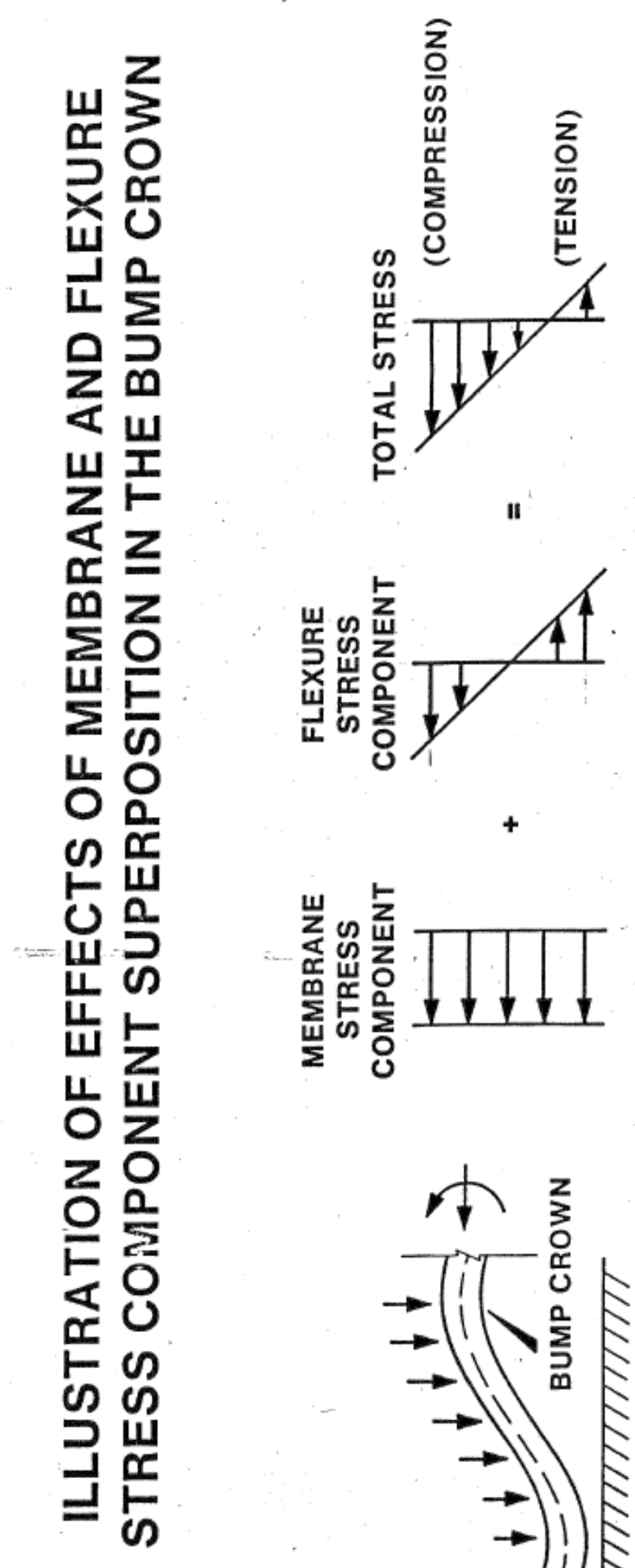

」ト

을

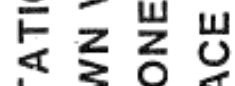

$\leftarrow 30 \leqslant$

잉 品

뭉

文

>

z峲心卡

w

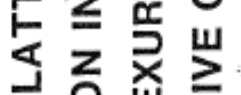

느을 을

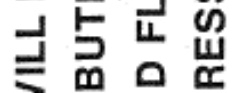

引 $\frac{m}{\alpha} \frac{a}{\alpha}$

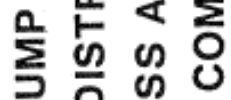

ต

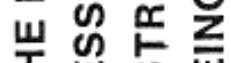

I

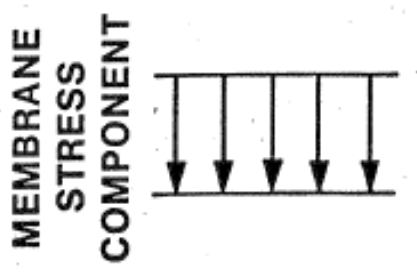

๘

エト匹

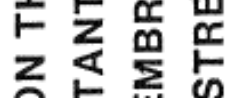

은포

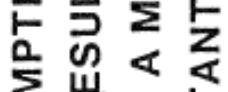

号㭊㭊

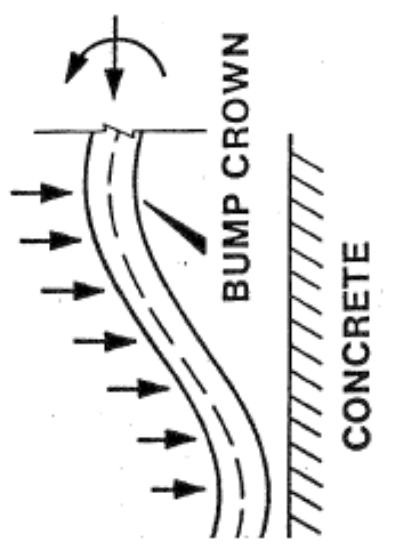

ஸ س

《崫㟧

ய山

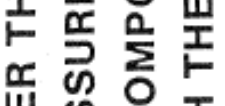

岂岕品 
RPP-RPT-54819, Rev. 0

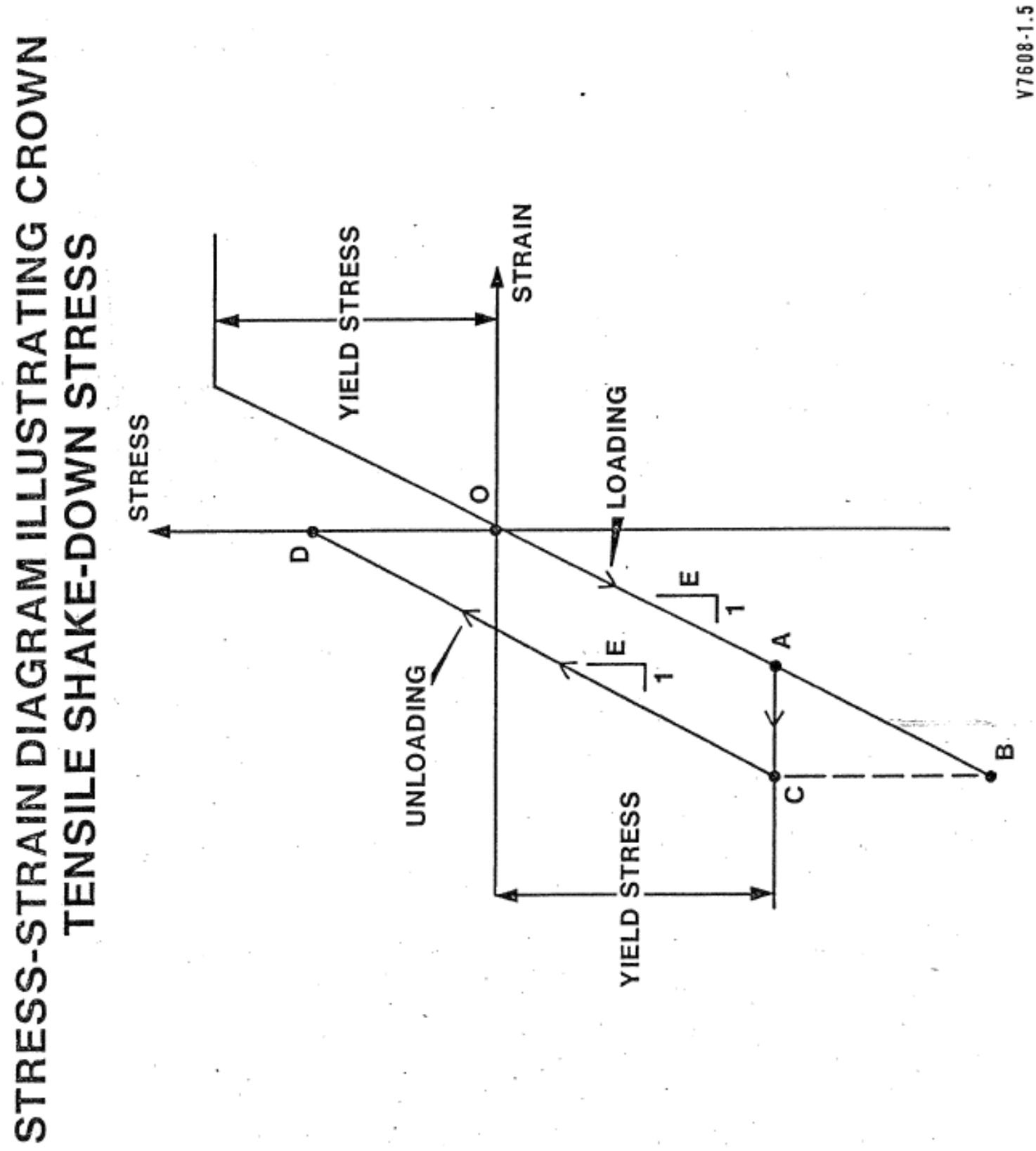


RPP-RPT-54819, Rev. 0

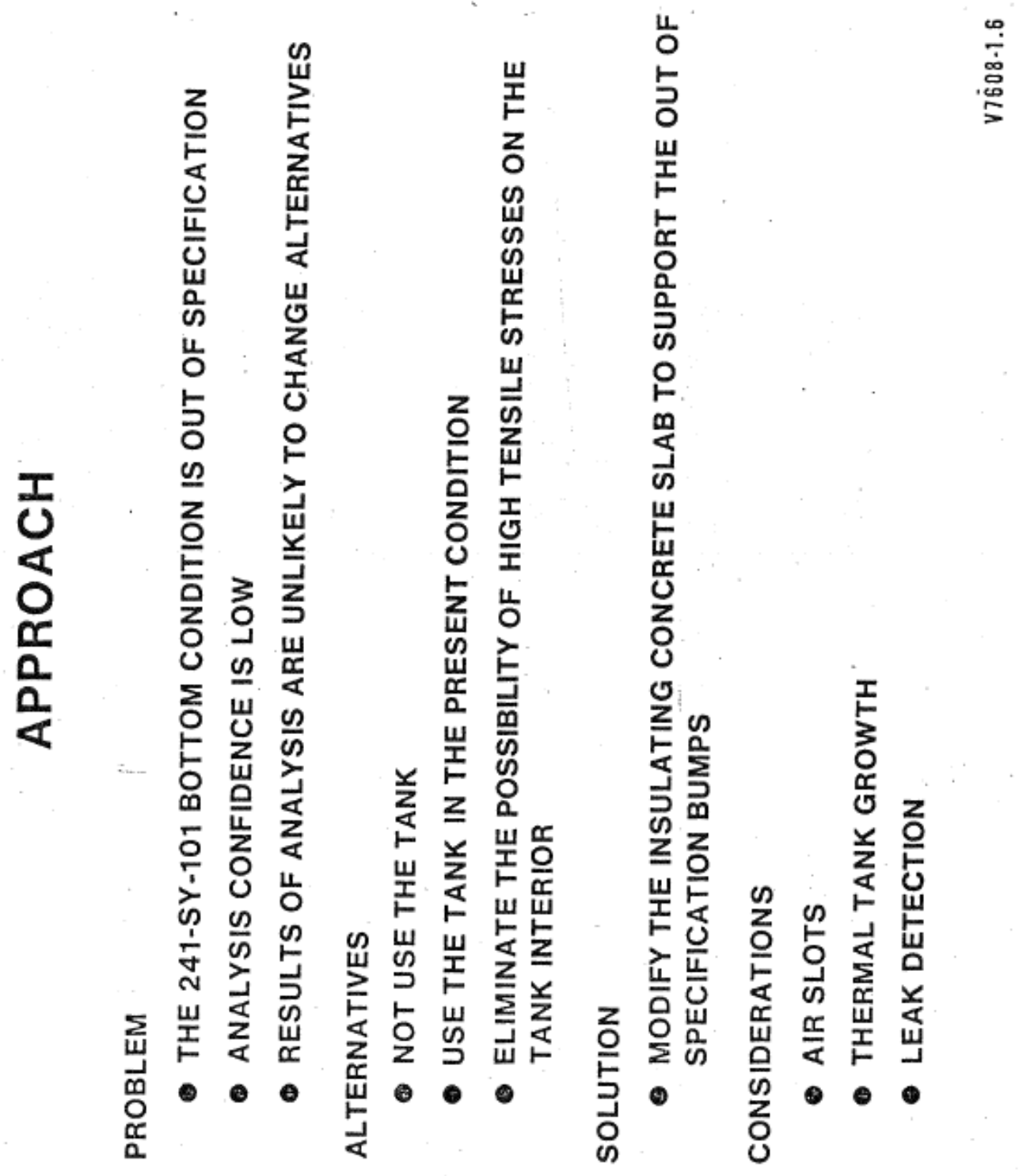


RPP-RPT-54819, Rev. 0

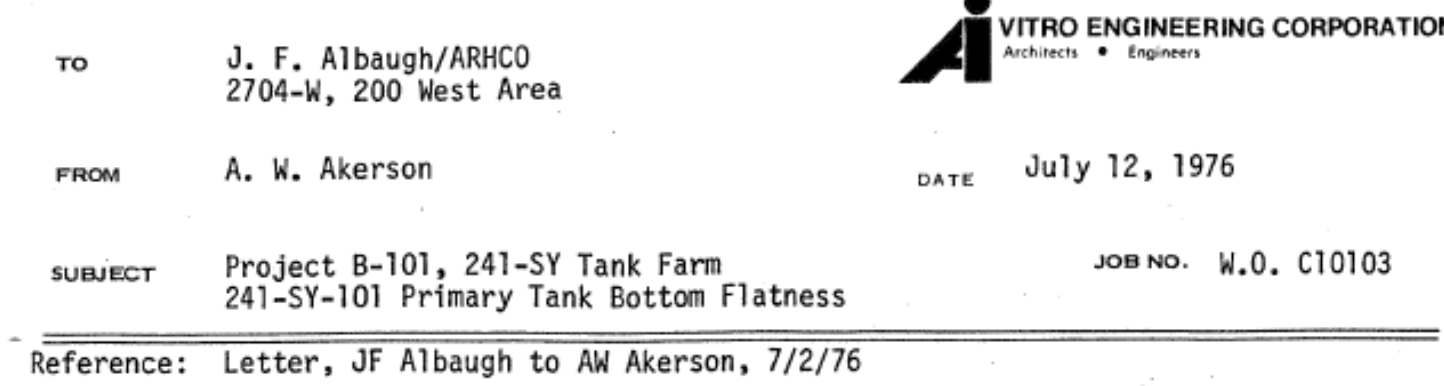

Vitro has reviewed the procedure for supporting the 241-SY-101 Tank Primary Bottom, as contained in the referenced letter, and concurs that this method of support should eliminate the high stresses that would otherwise be experienced by the "bumps".

We understand that you are planning to utilize this grouting procedure on the two bumps located approximately at $0^{\circ}$ and $180^{\circ}$ of the tank as shown on ES-B101-M6. Care should be taken, when chipping out existing refractory and packing in grout, not to contact the tank with metal tools that could scratch or otherwise damage the heat treated surface.
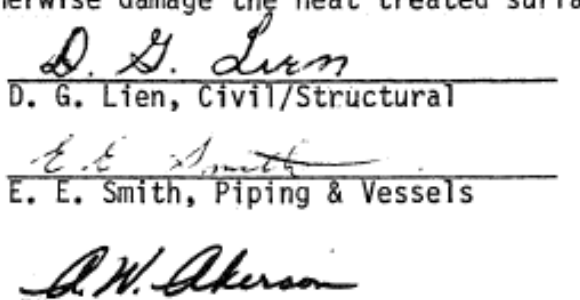

A. W. Akerson, Project Engineer

AWA:ec

cc: AG Lassila/ERDA-RL.

HA Zweifel/ARHCO, 2704W

JE Parsons/JAJ, 241-AW Construction Trailer

DG Lien

EE Smith

RR Wyer

Central Files

AWA/Files

LB 


ersedes 1etter
ied, July 2, 1976,

w/att.
Galbraith
Garfield
Huff
Lassila, ERDA-RL
Parsons, JAJ
Roal
Schrag
Vollert
Zweifel
e
ject File

Allantic Richfield Hanford Company

Federal Building

Richland, Washington 99352

Telephone 509 942-7411

Action: $7 / 12 / 76$

Ju1y 2, 1976

Vitro Engineering

Richland, Washington 99352

Attention: Mr. A. W. Akerson

Subject: PROJECT B-101 - SALT CAKE STORAGE FACILITIES, 241-SY TANK FARM

241-SY-101 PRIMARY TANK BOTTOM FLATNESS

Reference: (1) Letter, June 17, 1976, J. F. Albaugh to V. D. Schrag, "241-SY-101 Primary Tank Bottom Survey - Project B-101, Salt Cake Storage Facilities, 241-SY Tank Farm"

(2) Letter, May 4, 1976, D. E. Anderson to V. D. Schrag, "Bottom Flatness Survey Tank 101-SY"

Gentlemen:

A Battelle Northwest review of the 241-SY-101 Tank Bottom contour plot concluded that an analytic effort to evaluate the stress levels in the tank bottom would produce results with a low confidence level. Rather than undertake such an analytic effort, it has been proposed that the bumps be supported from beneath thus eliminating the high stresses associated with bump deflection.

Would Vitro Engineering please review this approach. Included in this effort should be a review of the stress levels in the supported areas. In addition, the adequacy of the attached procedure for supporting the 241-SY-101 primary tank botton in the critical areas defined by Drawing ES-B-101-M6 should be evaluated.

Very truly yours,

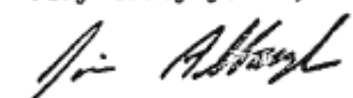

J. F. Albaugh

Project Engineer

JFA:sh

Att.

\section{RECEIVEM}

JUL ? RECEIVED

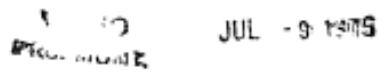

VITRO PRO, MGMT: 


\section{App Figure C-12. Investigation of Tank SY-102 Insulating Refractory}
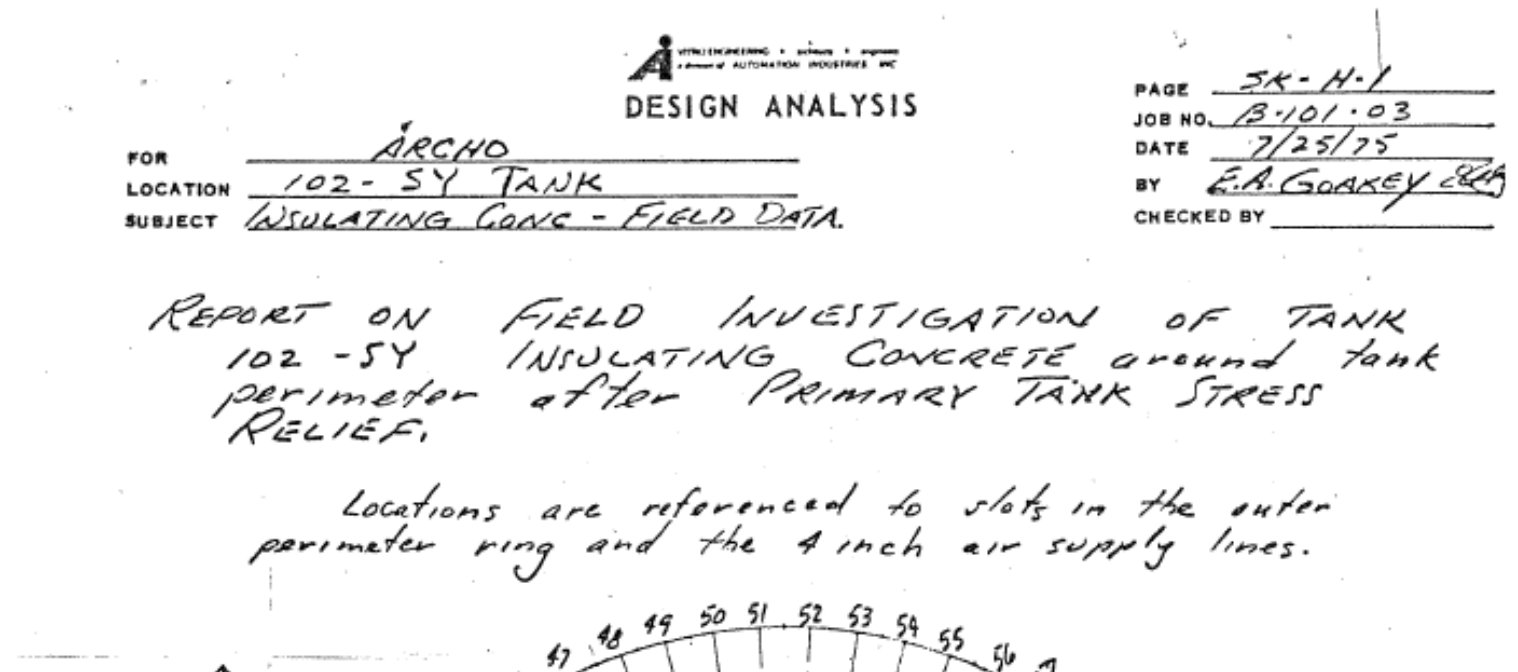

$$
\begin{aligned}
& \text { Locations are reforenced to slats in the iuter } \\
& \text { perimeter ring and the } 4 \text { inch ar supply lines. }
\end{aligned}
$$
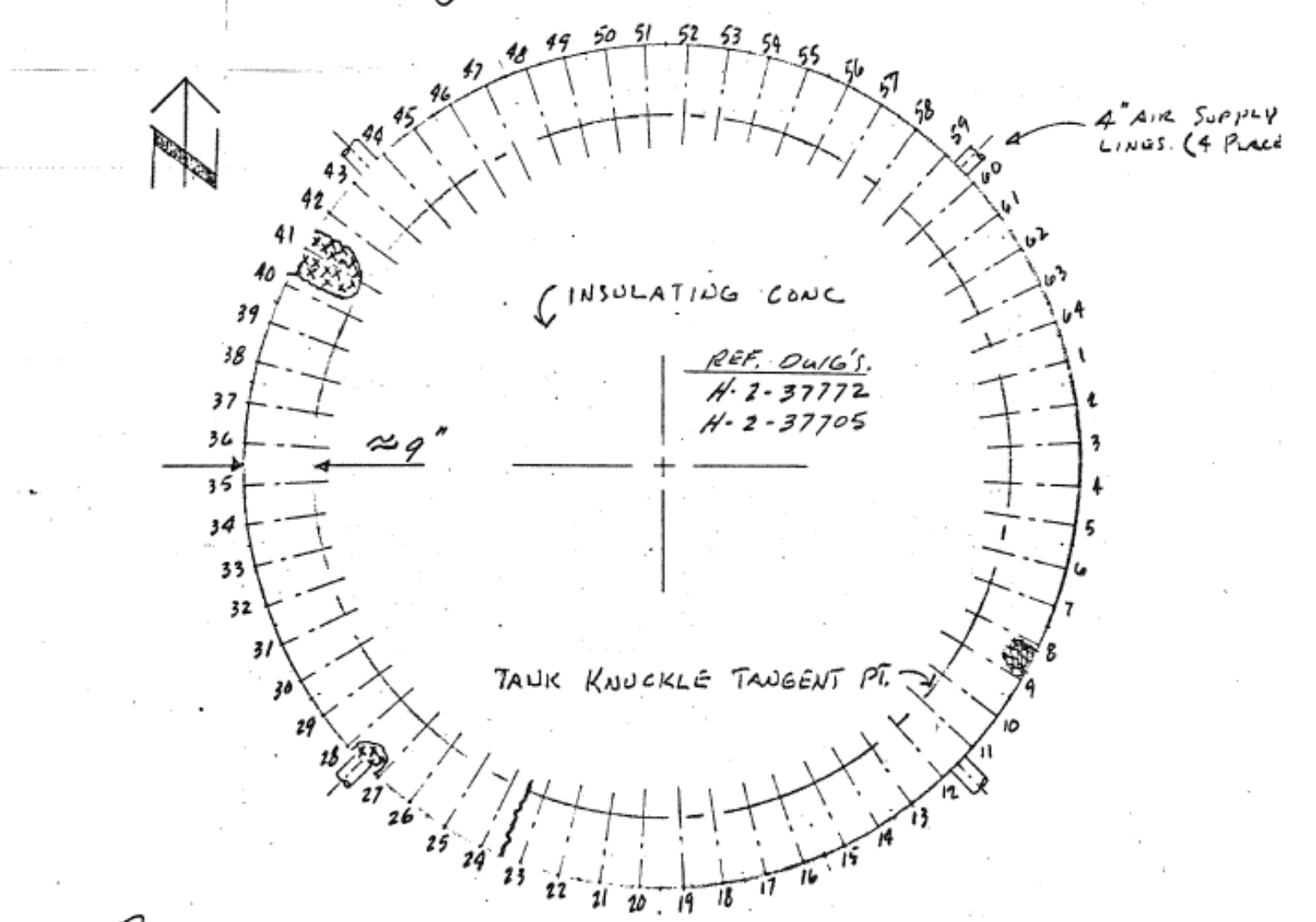

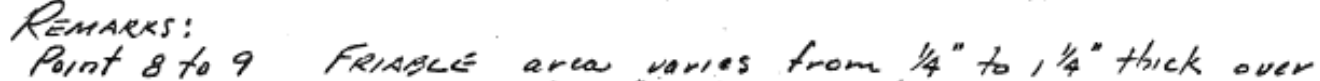
Powe 23.24 en "wide cuack (radial)

Point 41 " thick top layem may approach knuckle area, Nore: Appreximately so so of perimeter area had triable

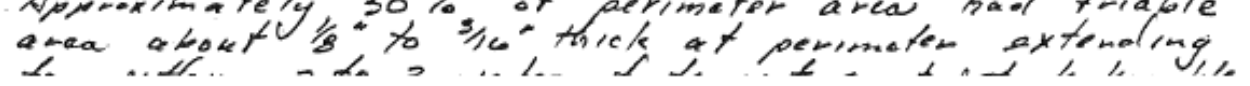




\section{App Figure C-13. NCR B-101-32-2307-17, 241-SY Tank Farm Salt Cake Storage Facilities}

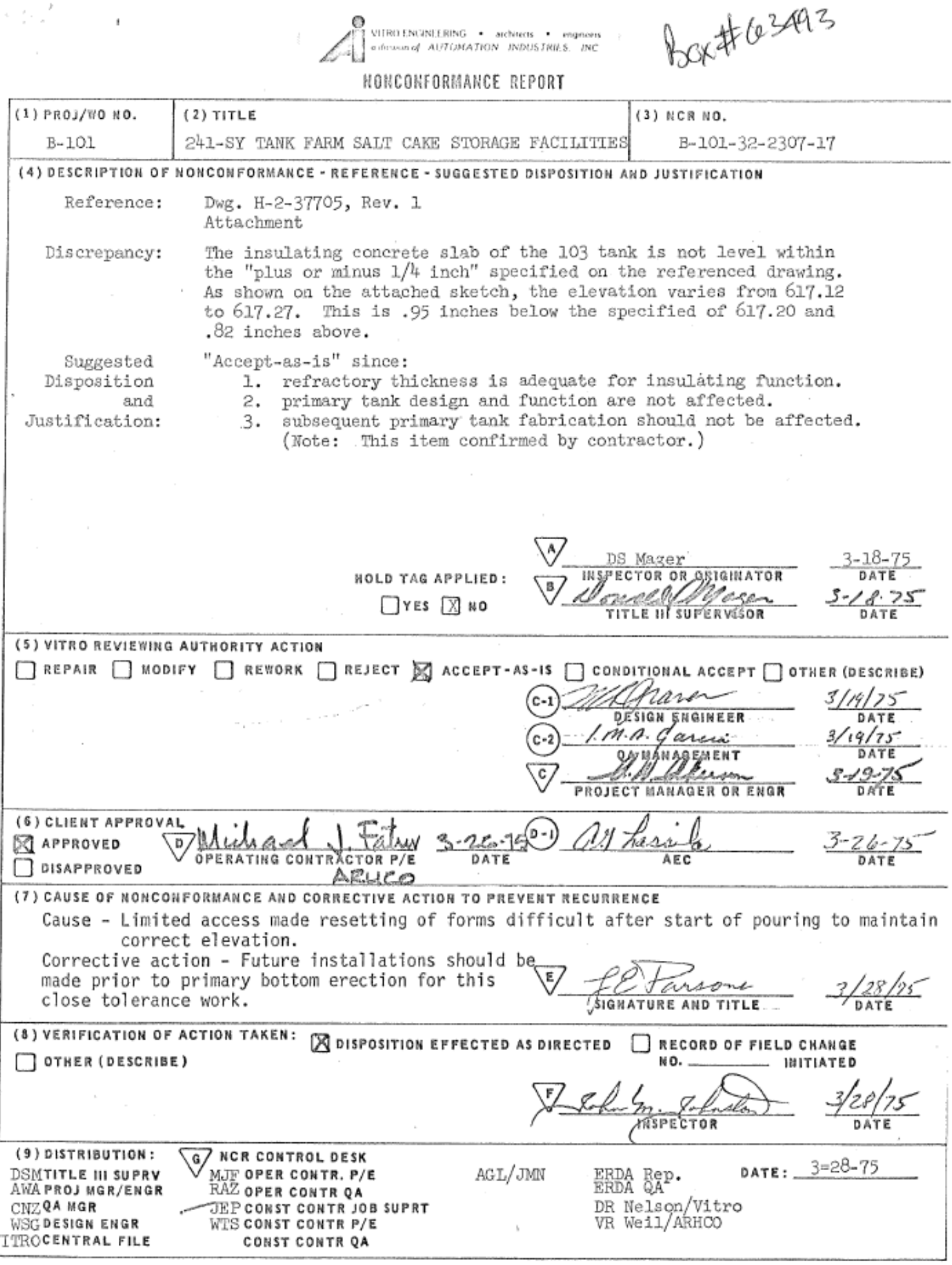




$$
\begin{gathered}
\text { ke Trac wu } \\
\text { Th 10: }
\end{gathered}
$$

Project B-101 sellot:

Fulu,yle.

$-A \longrightarrow$

ATTACHMENT TO NCR \# B-101-32-2307-17

Plan elev.

617.20

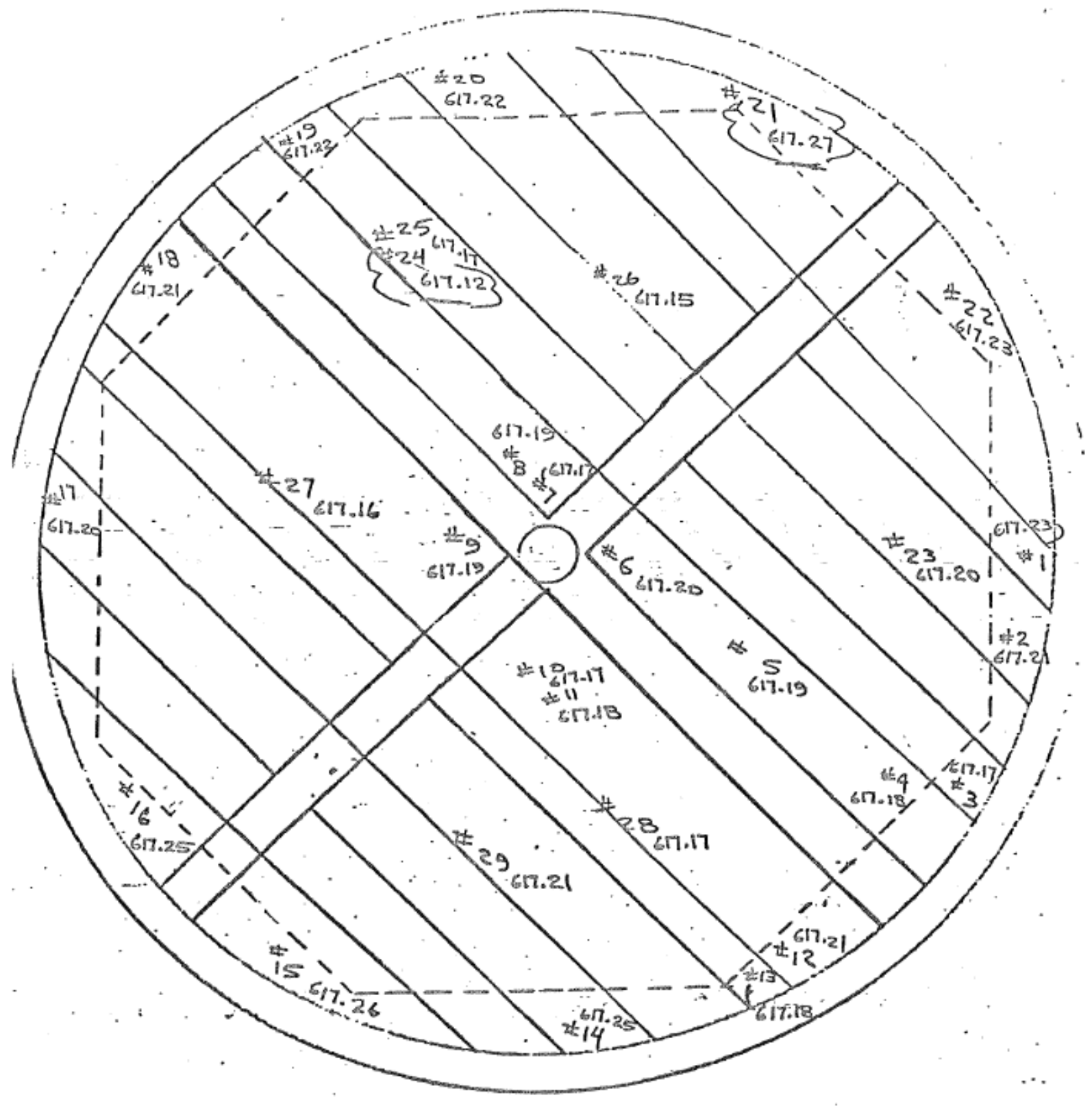


RPP-RPT-54819, Rev. 0

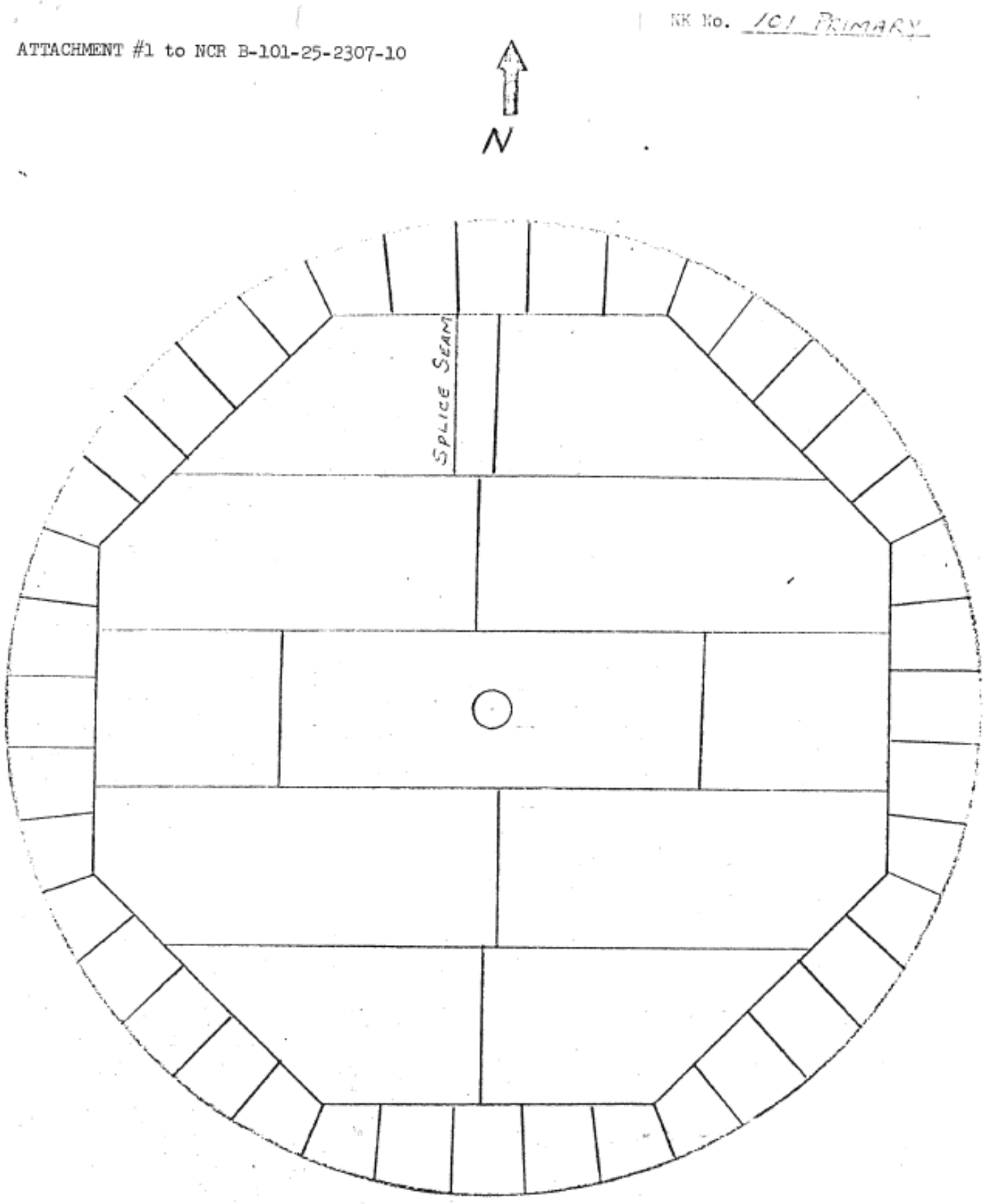


RPP-RPT-54819, Rev. 0

App Figure C-14. NCR B-101-19-2307-5, 241-SY Tank Farm Salt Cake Storage Facilities

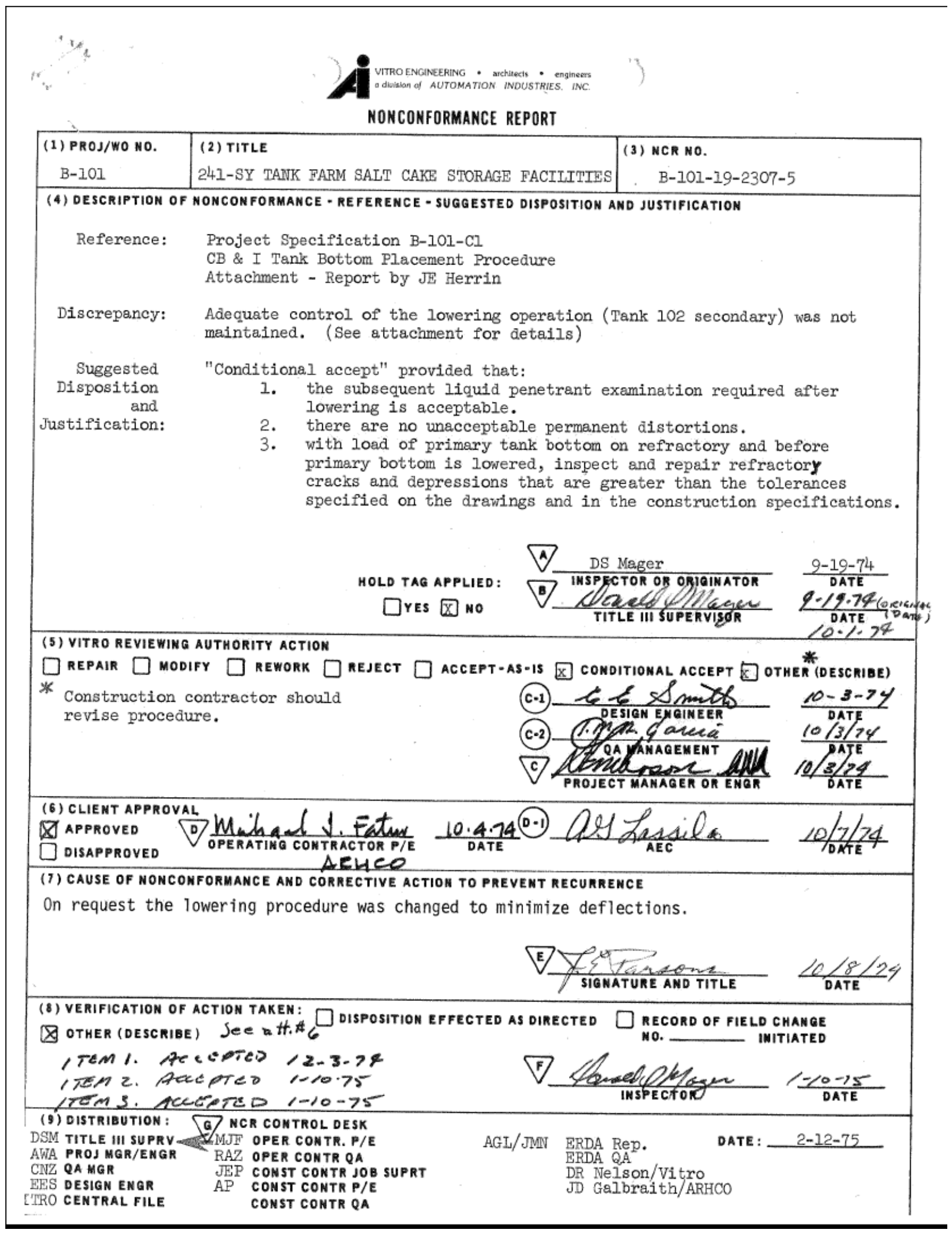


RPP-RPT-54819, Rev. 0

)

automation INDUSTRIES, INC

VITRO ENGINEERING DIVISION

INTER - OFFICE MEMORANDUM

DATE September 21, 1974

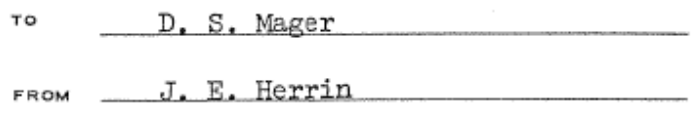
Vitro Trailer, 200-W Area
(LOCATION OR DEPARTMENT)
Vitro Trailer, 200-W Area
(LOCATION OR DEPARTMENT)

SUBJECT PROJECT B-IO1 - PLACEMENT OF 102 SECONDARY TANK BOTTOM

On 9-19-74 the construction contractor lowered the 102 secondary tank bottom. As prescribed in CB \& I's procedure, eight hydraulic jacks were set equally spaced around the tank bottom. Two manifolds were used, each controlling four jacks. These four jacks were independently operated by one man. (See attachment \#1.)

At approximately 10:00 AM the tank was elevated by the two manifold operators, but not simultaneously. After the first tier of cribbing was removed, the Station 1 manifold operator lowered his jacks to the next tier (approximately $\left.8^{\prime \prime}\right)$. The jacks controlled at Station 2 remained fully extended. This produced'a scallop effect on the South and West sides of the tanks. The Station 2 manifold operator released his jacks bringing the tank to rest on the next tier. (See attachments 2 \& 3.)

At that time, Don Mager, Vitro Field Engineer, informed Don Anderson, Vitro Project Engineer, of the situation. Don Anderson decided the operation could continue if $\mathrm{CB} \& \mathrm{I}$ lowered each jack in one inch increments starting at one point and circling the tank. This method was attempted throughout the lowering operation. However, with each lowering operation, the tank deflected as shown on Attachments 4 \& 5 .

The lowering operation was completed at approximately 2:30 PM.

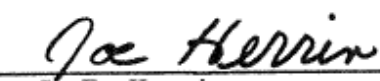

JEH: jf 
RPP-RPT-54819, Rev. 0

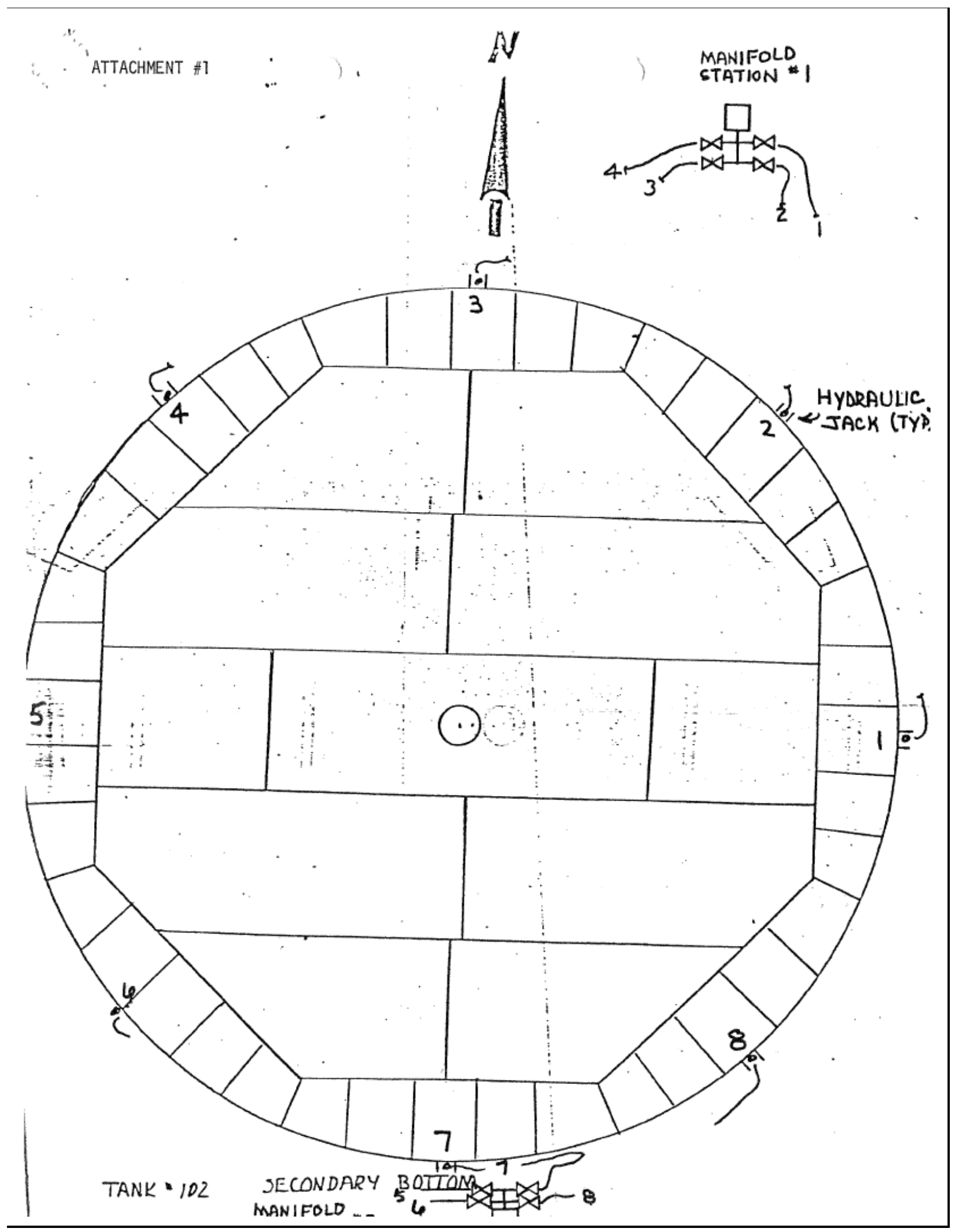




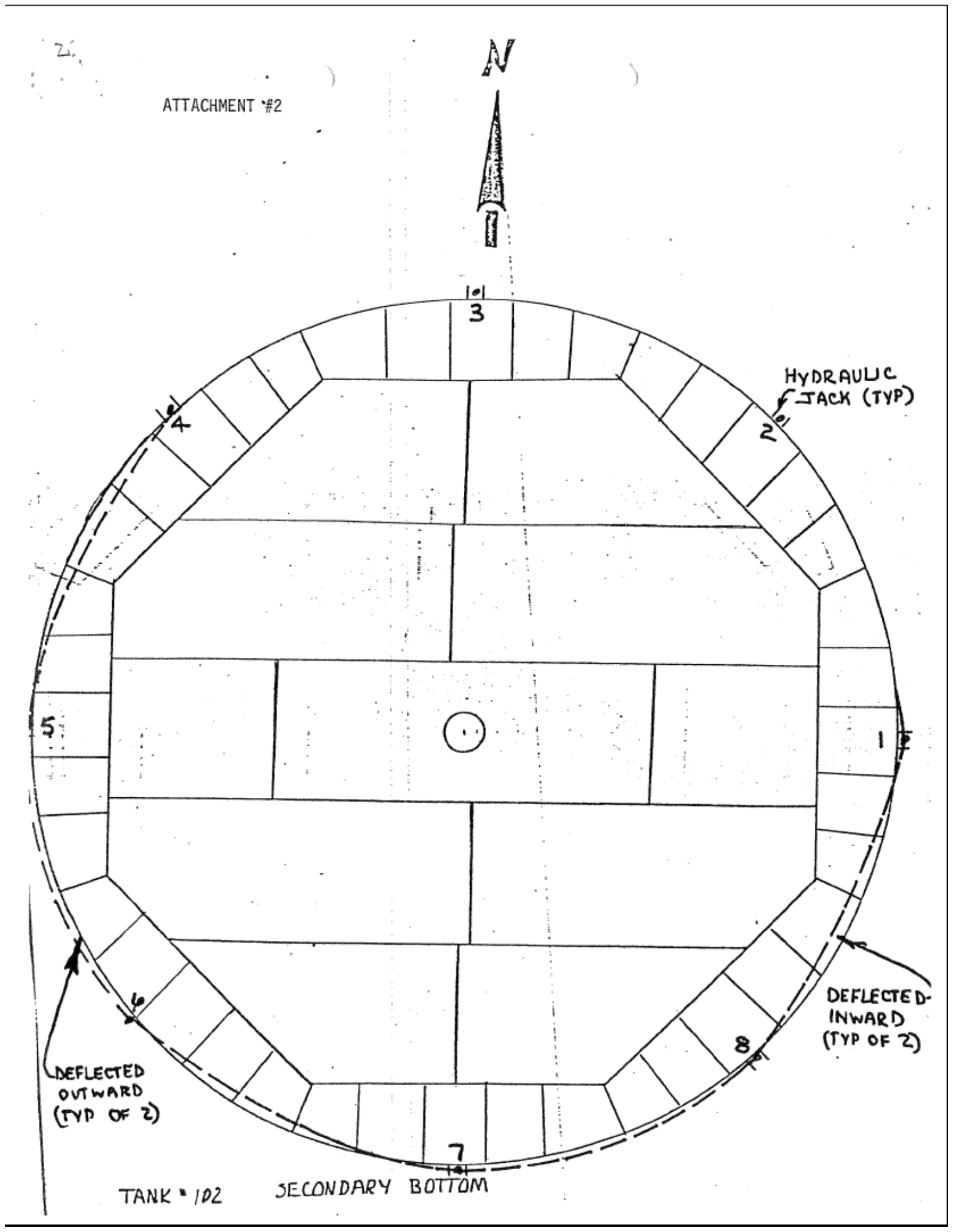


RPP-RPT-54819, Rev. 0

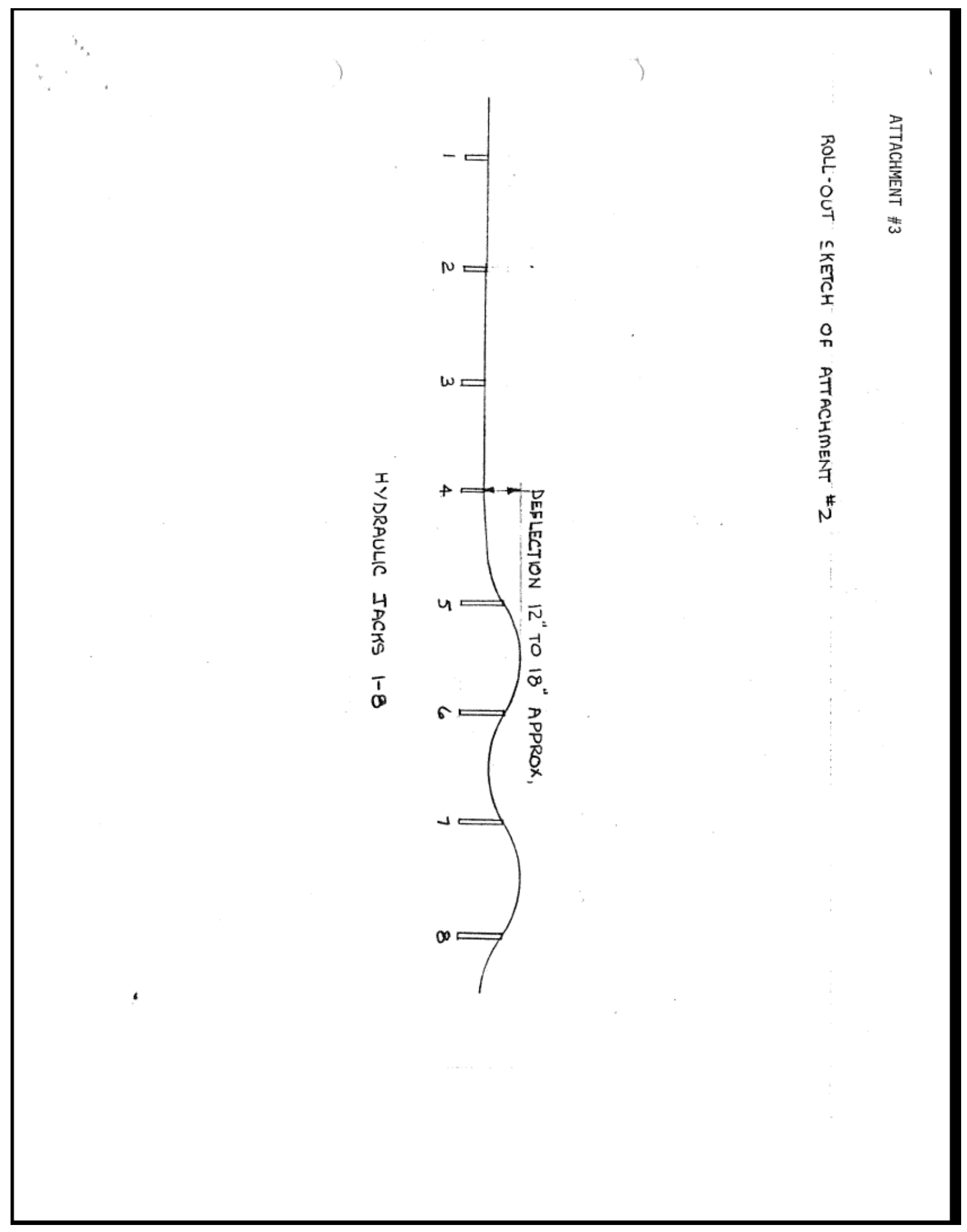


RPP-RPT-54819, Rev. 0

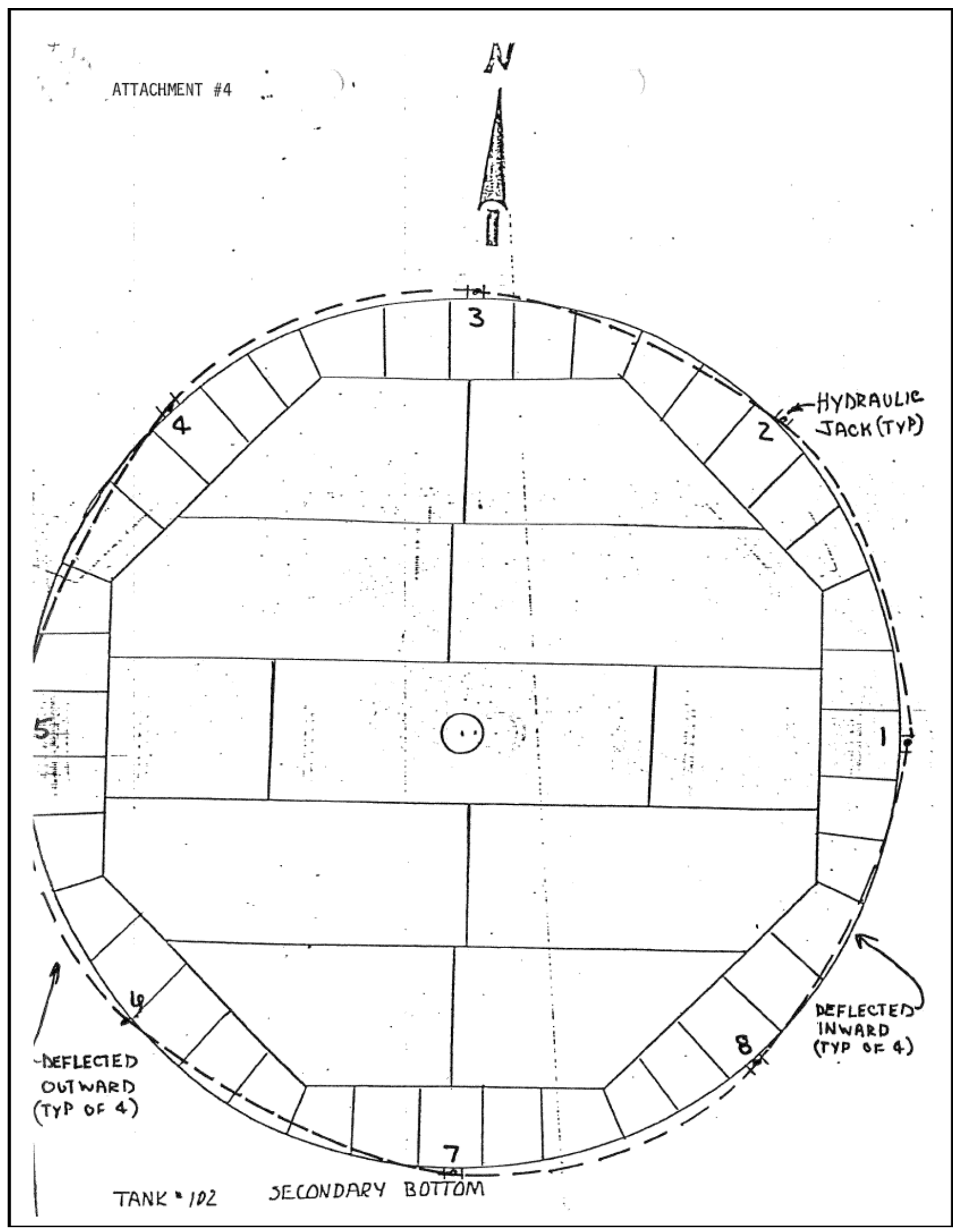


RPP-RPT-54819, Rev. 0

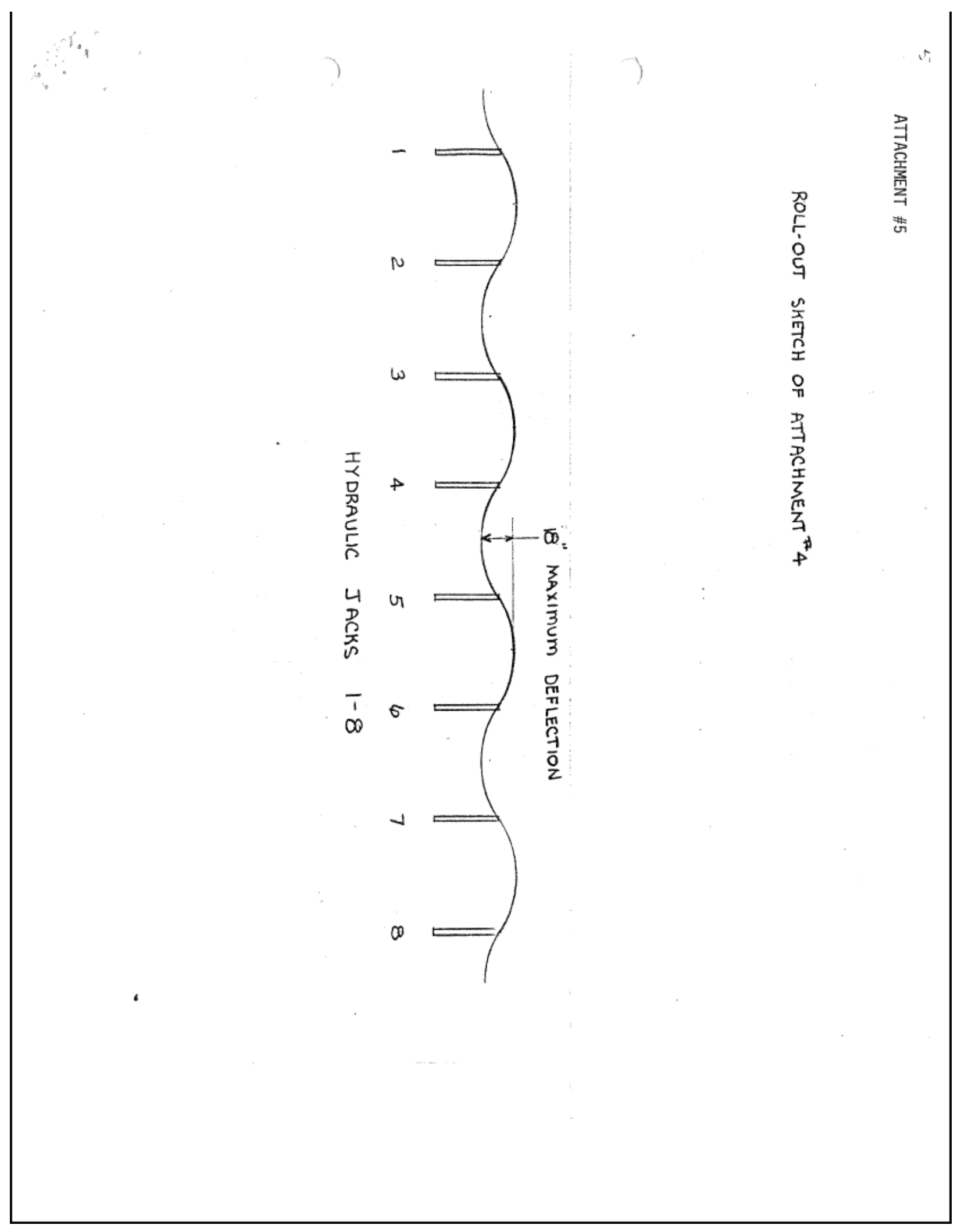


ATTACHMENT \#6 to NCR B-101-19-2307-5, Item \#3 ff pard DATE: 1-10-75 ATTACHMENT \#2 INCR B-101-20-2307-6, Item \#2 ATTACHMENT \#3 to NICR B-101-21-2307-7, Item \#2

(8) Verification of Action Taken: Statement of Condition of Refractory

The condition of the refractory was carefully examined prior to lowering of the Tank 102 Primary Bottom. One area (approximately $4^{\prime} \times 6^{\prime}$ ), was found to be sunken under the loading of a cribbing stack, and was subsequently repaired on February 8, 1975. The repaired area and the remainder of the foundation appeared to be in very satisfactory condition. During the examination of the refractory by E. S. Davis (Vitro) and me, small patches of ice were visible on the surface. Hammer testing of these and other areas provided no indication of frozen or defective material. Minor cracks were noted over the air supply piping and around other cribbing stacks, but were not considered detrimental. Thus, I informed J. E. Parsons (JAJ) and M. J. Fatur (ARHCO) that the condition was considered satisfactory, and that lowering may commence.

For historical purposes, it appears at this time that the product used for the refractory foundation may contain superior qualities with respect to cold weather tolerance than those previously experienced. 
App Figure C-15. NCR B-101-25-2307-10, 241-SY Tank Farm Salt Cake Storage Facilities

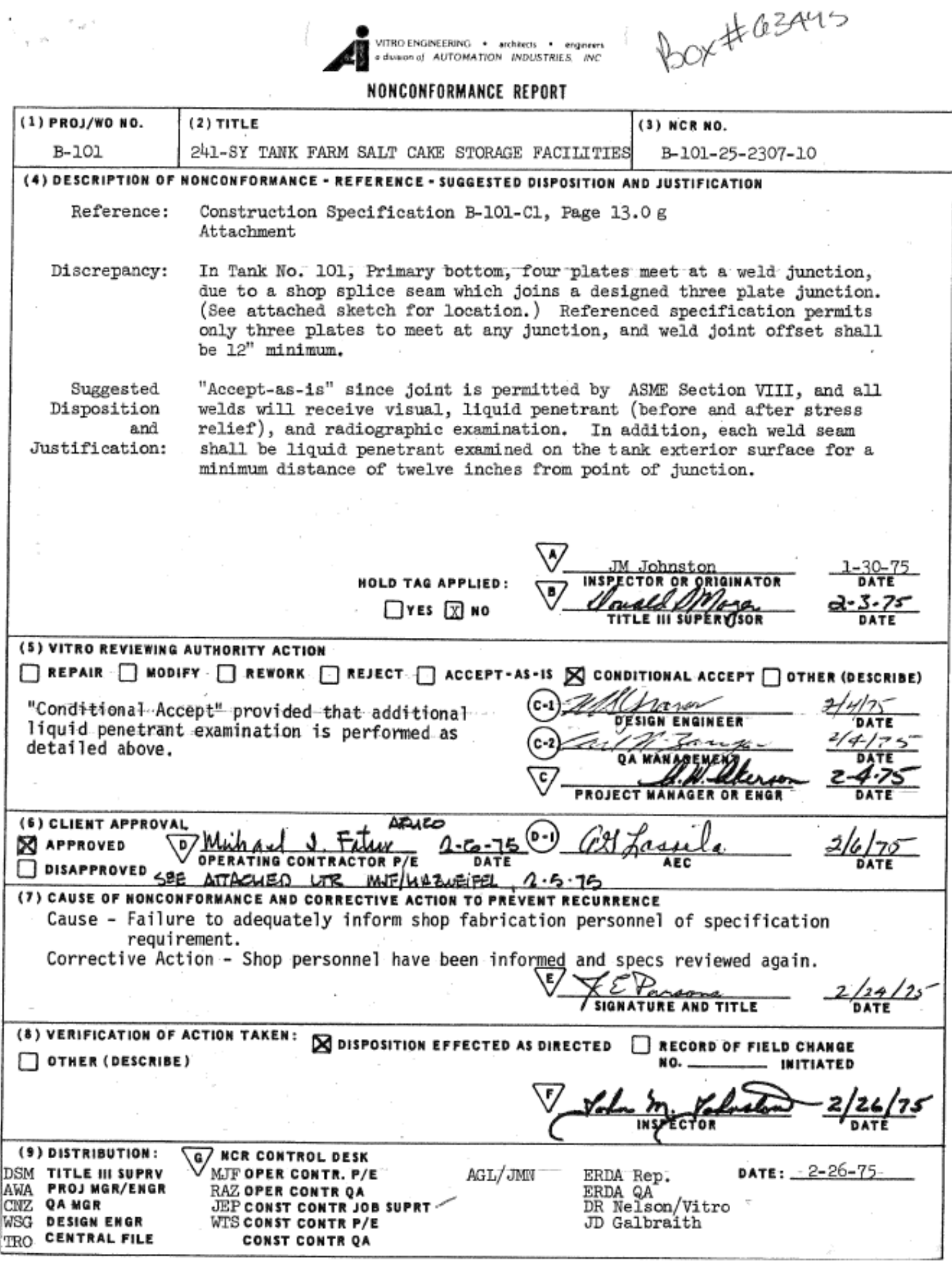


RPP-RPT-54819, Rev. 0

App Figure C-16. NCR B-101-26-2307-11, 241-SY Tank Farm Storage Facilities

NONCONFORMANCE REPORT

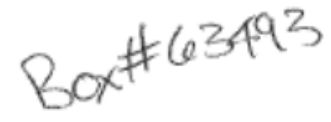

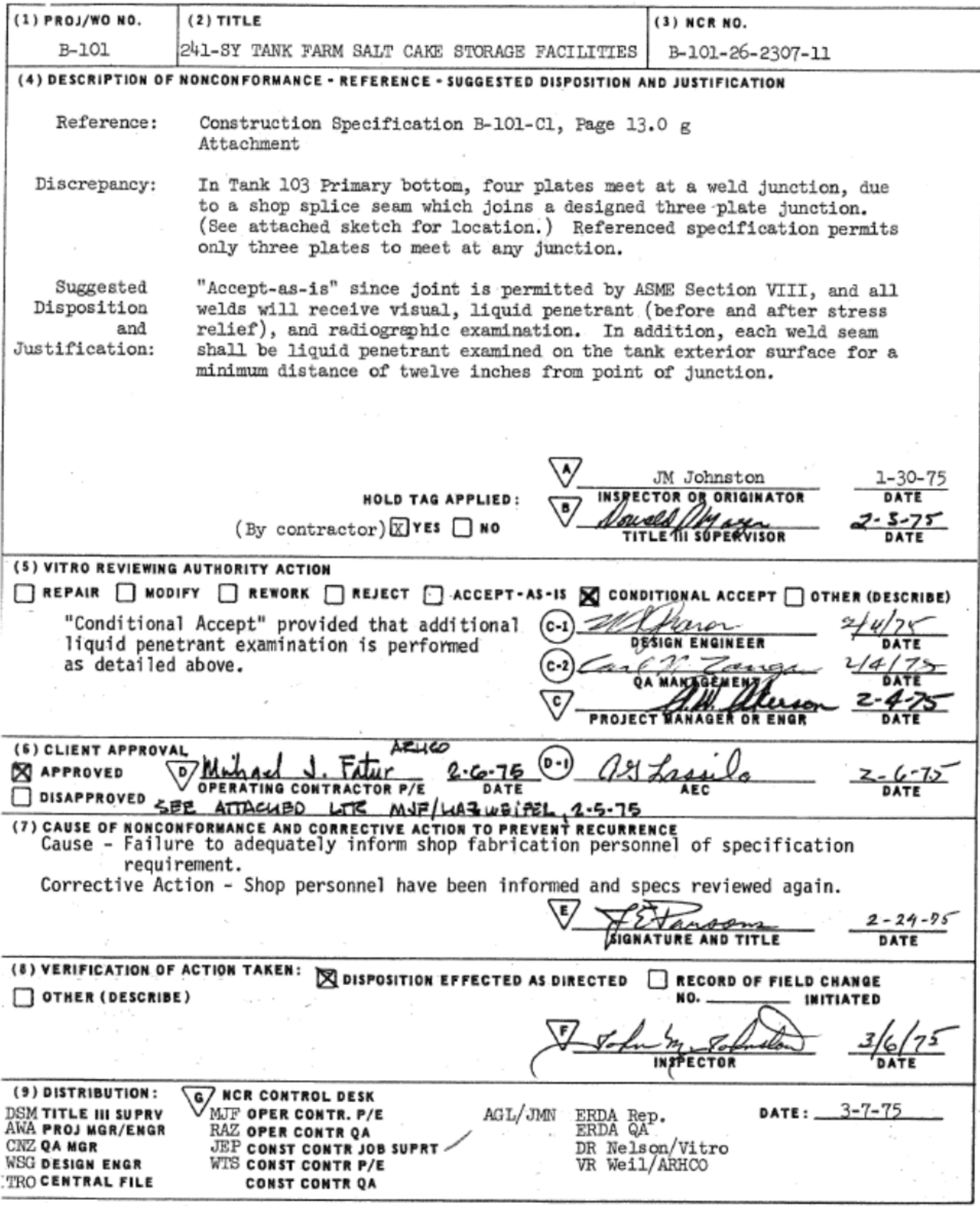


RPP-RPT-54819, Rev. 0

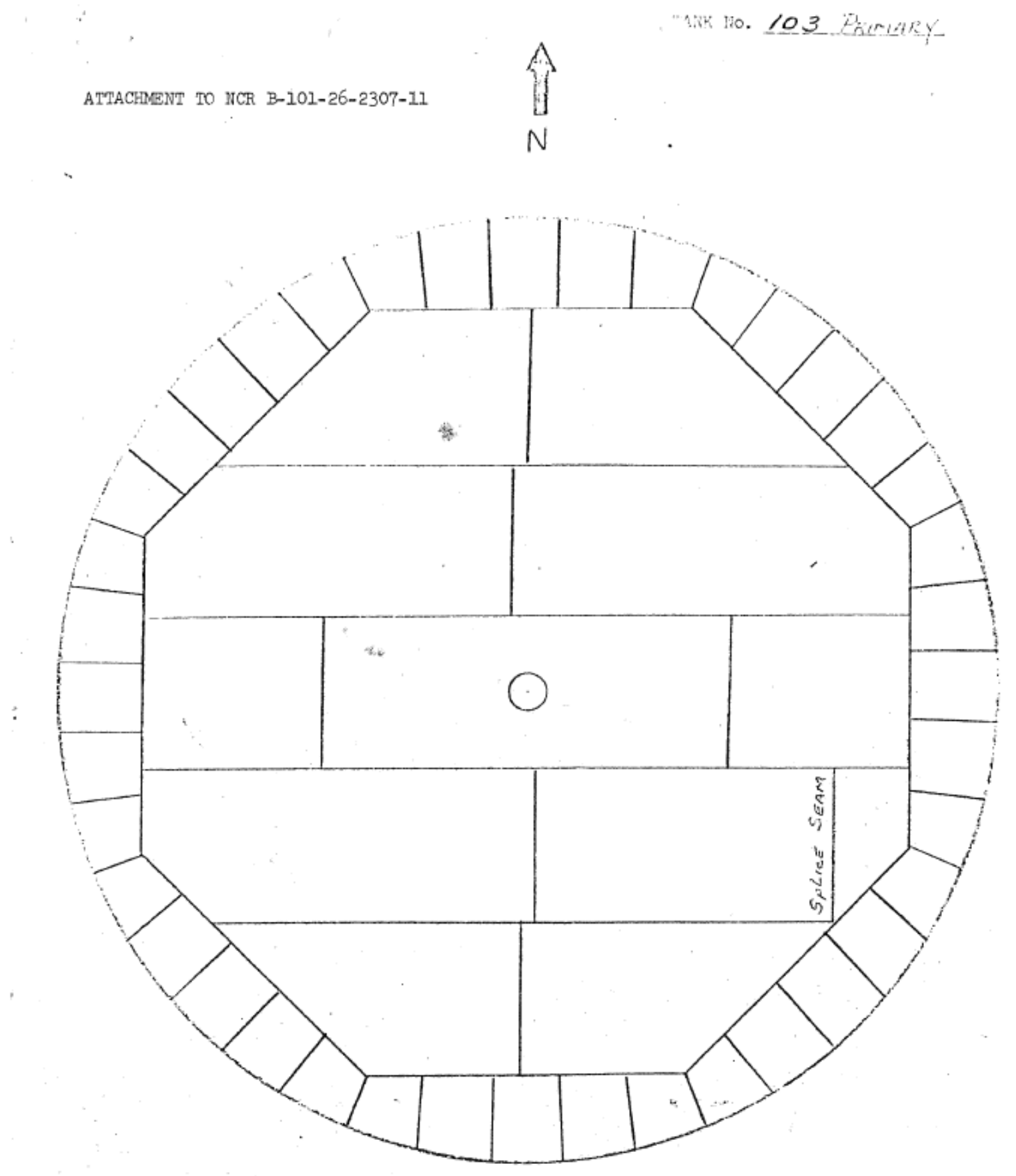


RPP-RPT-54819, Rev. 0

App Figure C-17. NCR B-101-33-2307-18, 241-SY Tank Farm Salt Cake Storage Facilities

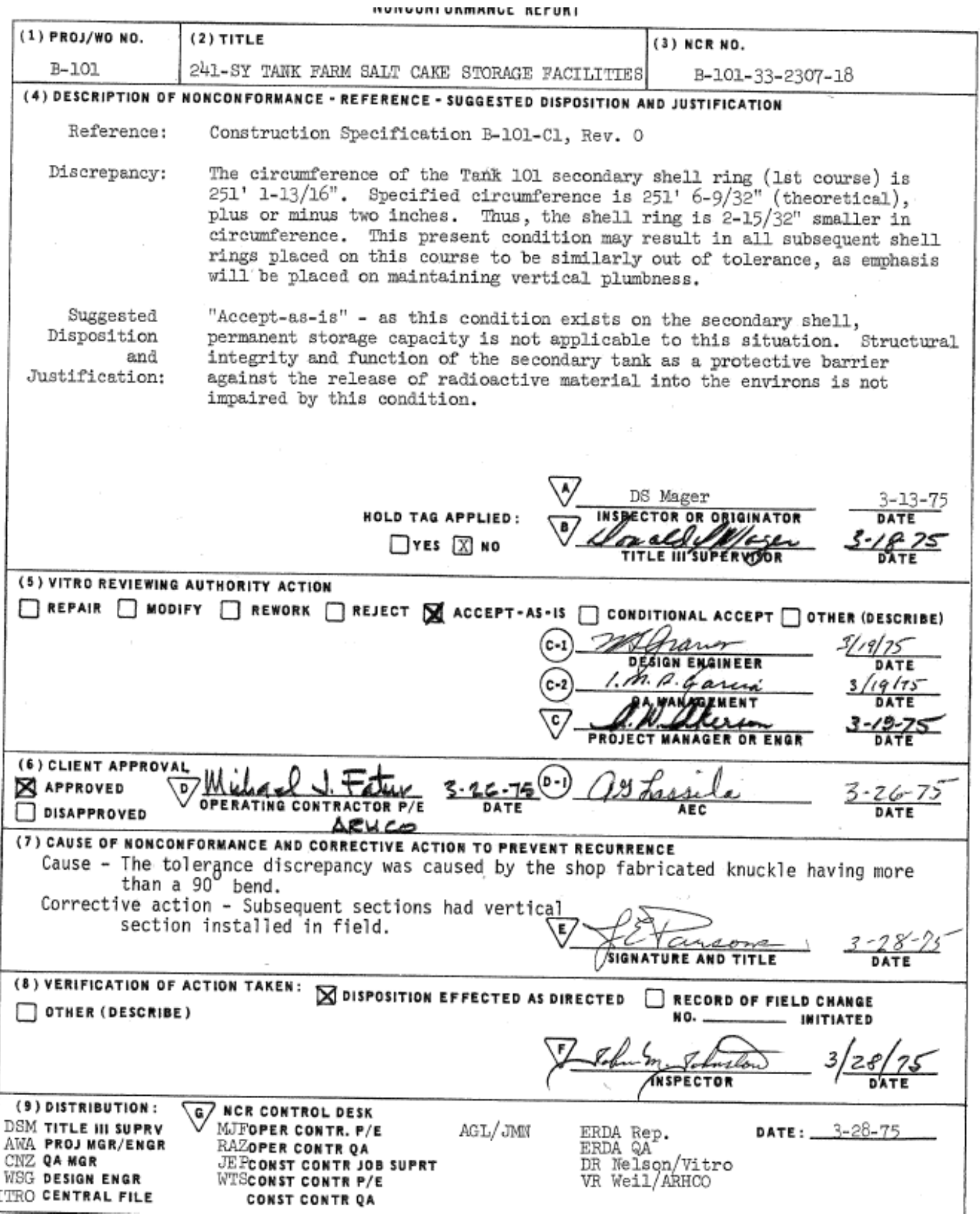




\section{App Figure C-18. NCR B-101-35-2307-20, 241-SY Tank Farm Salt Cake Storage Facilities}

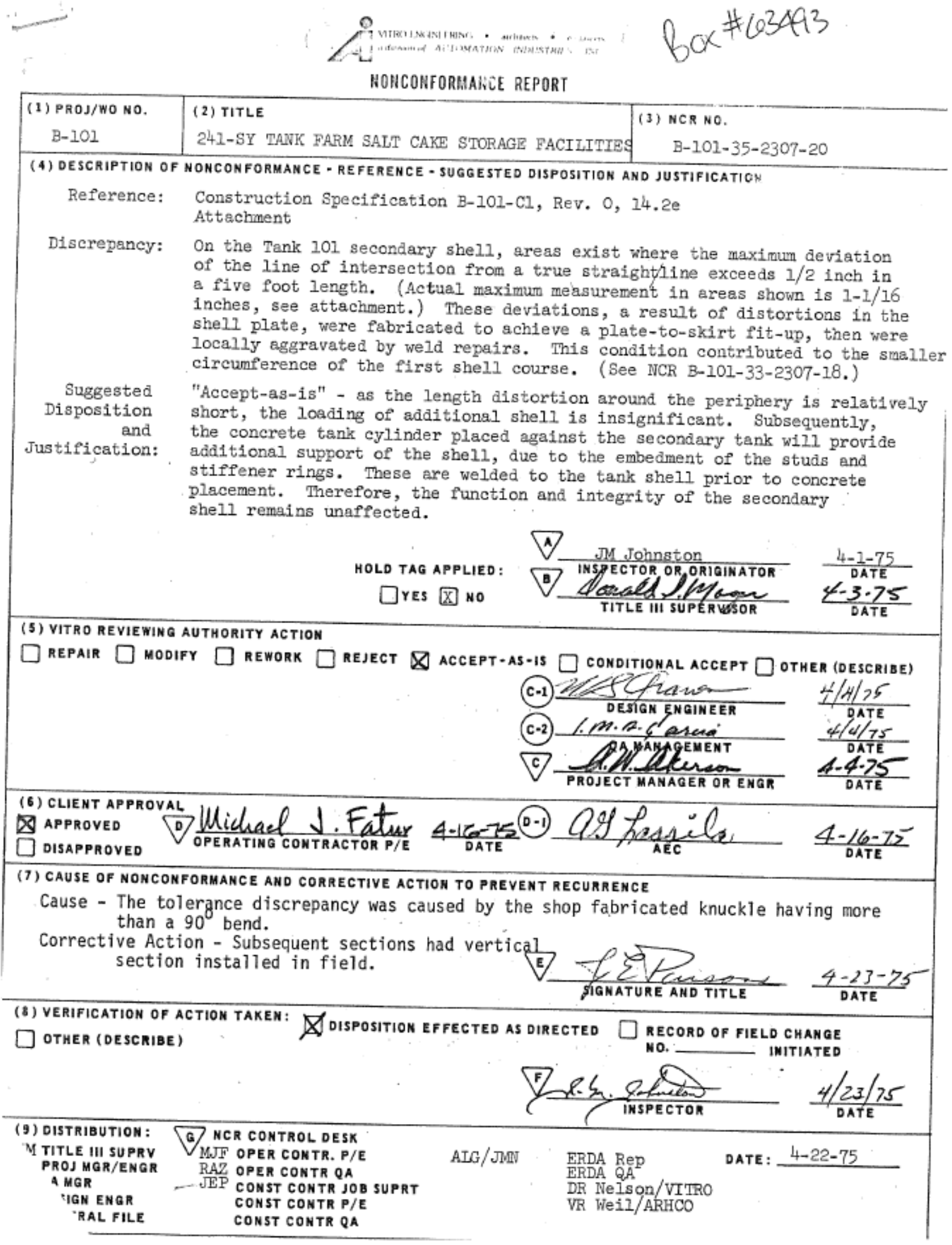


RPP-RPT-54819, Rev. 0

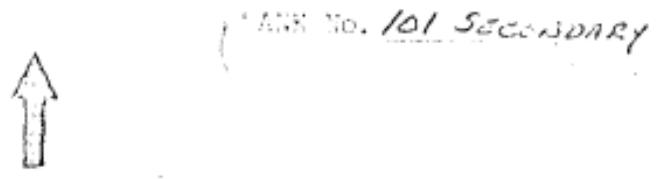

$\checkmark \quad$ ATTACHMENT TO NCR B-101-35-2307-20

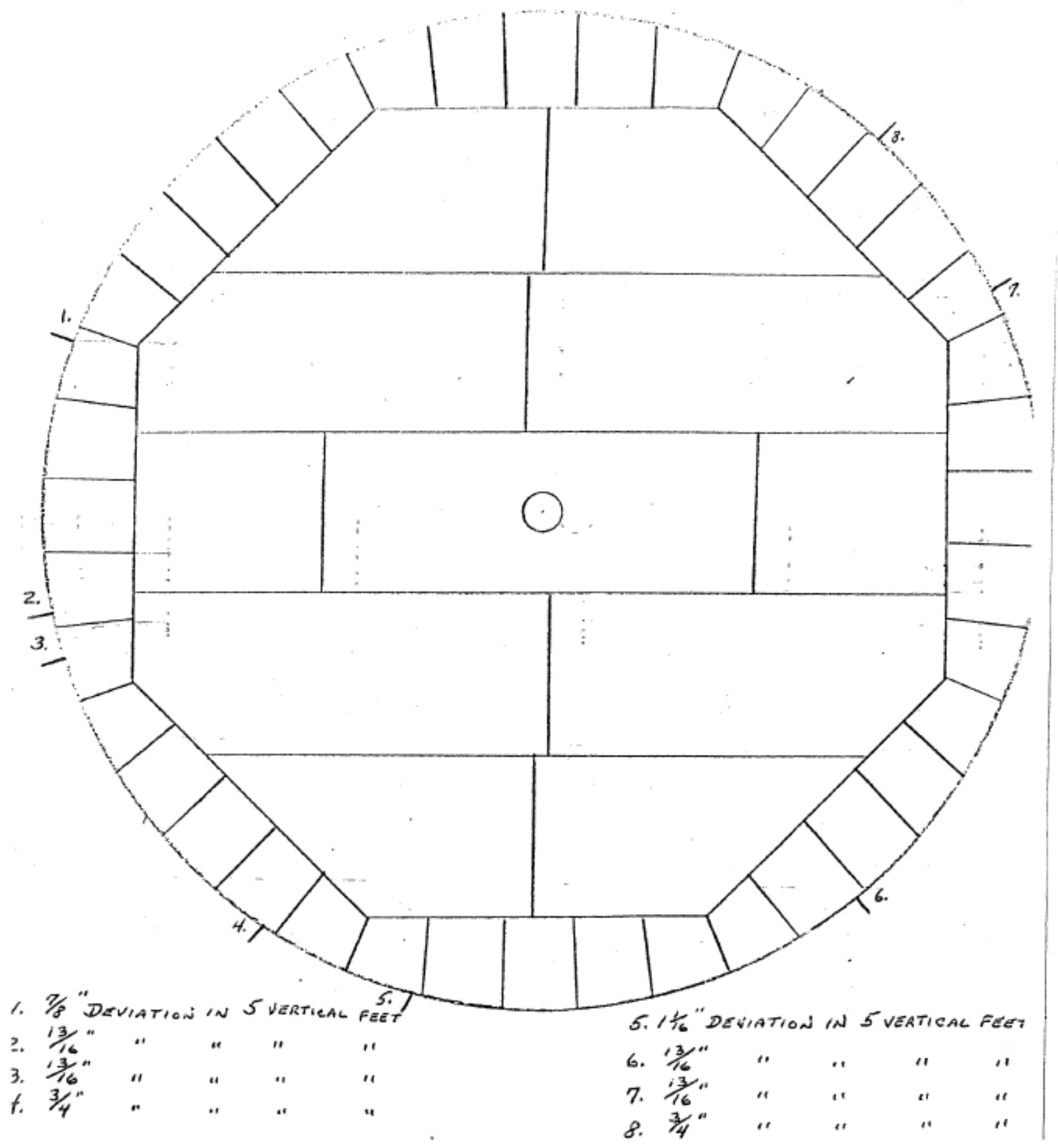


RPP-RPT-54819, Rev. 0

App Figure C-19. Tank SY-101 Secondary Liner Circumference Deficiency Report

\section{DEFICIENCY REPORT}

Date Initiated $3-21-75$

Initiated BY D. FOPD

Report No.

Page 1
23 of 1

PART A: THE CIRCUMFERENCE OF THE SECONDARY TANKS \#101.

DESCRIPTION: A 103153 Y $/ 2$ " LESS THAN THE THEORETICAL CIRCUMF ERENCE, THIS EXCEEDS THE TOLEPANCE ALLOWANCE INTHE DIMENSIONA CONTROL PROCEDURE BY / 1/2" (ALLOWABLE DEVIATION $= \pm 2$ "' CAUSE: BOTTOM KNUCKLE IS SLIGHTLY TIPPED IN + FIRST RING HAD
TOBE TRIMMEO O + INCHES.

PART B:

CORRECTIVE ACTION:

$$
\begin{aligned}
& \text { 1. LEAVE SECONDARY CIRCUMFERENCES ONTKIOI } 103 \text { AS IS FOT AML } \\
& \text { SHELL RINGS. } \\
& \text { 2. CUSTOMERTO EVALUATE THE CONSEQUENCES OF (I) ABOVE BASED } \\
& \text { ON THEIR REQUIPEMENTS. } \\
& \text { 3. CUSTOMER TO HWOW OR REJECT THE "LEAVE ASIS"RESOLUTION } \\
& \text { BASED ON (2) ABOVE }
\end{aligned}
$$

PEFER TO FTM H

Deficiency has been resolved:

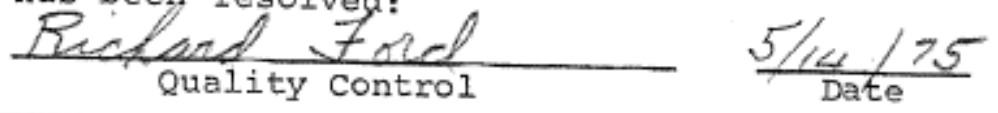


RPP-RPT-54819, Rev. 0

App Figure C-20. NCR B-101-29-2307-14, 241-SY Tank Farm Salt Cake Storage Facilities

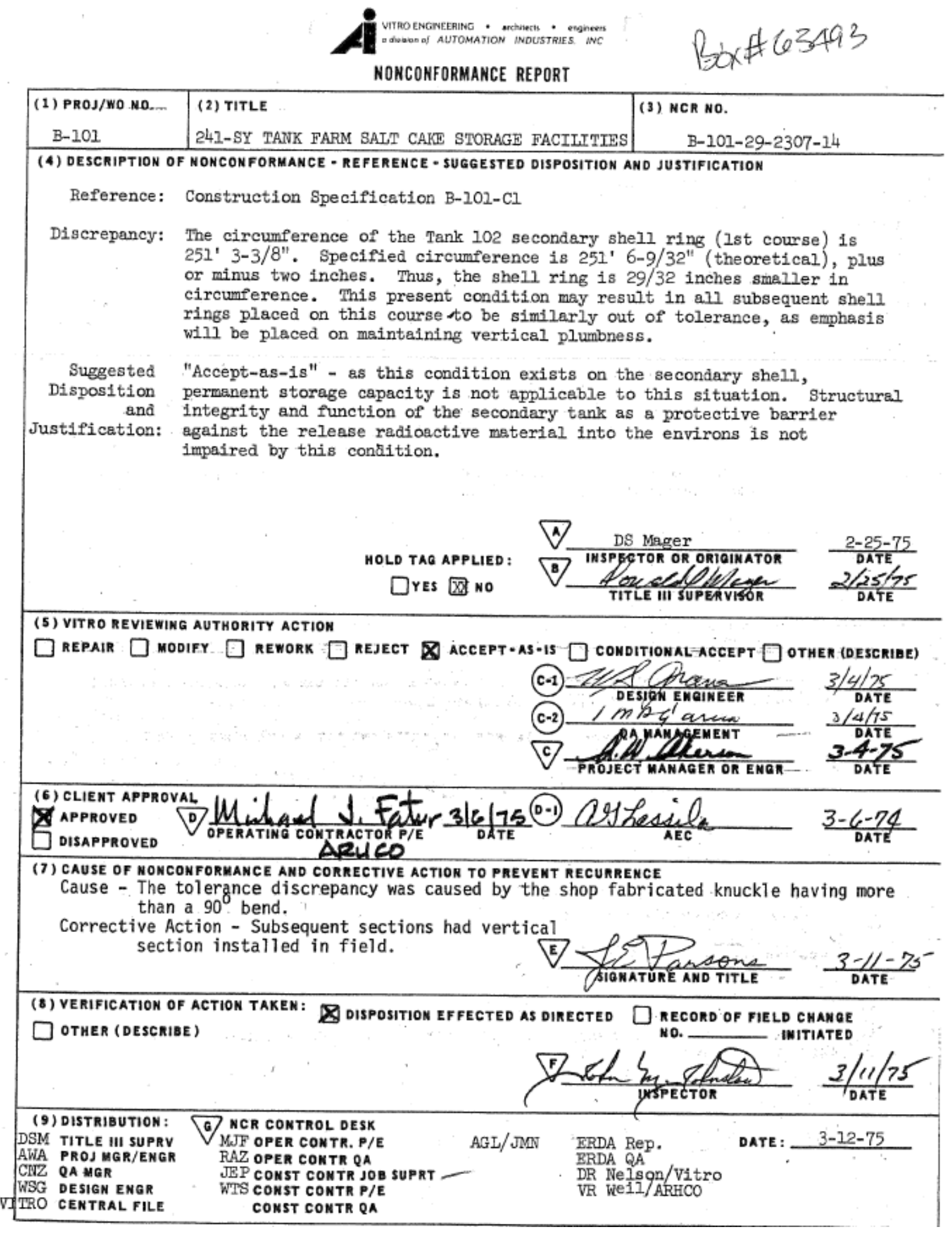


RPP-RPT-54819, Rev. 0

\section{App Figure C-21. Tank SY-102 Secondary Liner Circumference Deficiency Report}

WHVAGU BFIDGE \& IRON COMPANY

\section{DEFICIENCY REPORT}

Date Initiated $2-12-75$

Initiated BY R. FoPD

Report No. 20

Page 1 of 1 i

PART A: THE CIPCUMFEPENCE OF THE SECONDARY TANK \#102
DESCRIPTION:

IS H"LESS THAN THE THEORETICAK CIRCUMFERENCE.

THIS EXCEEDS THETOLERANCE ALLOWANCE IN THE DIMENSIONAL

CONTROL PROCEDURE BY 2" CALLOWABLE DEVIATION $= \pm 2$ "

THE MAXIMUM DIAMETER DEVIATION OF THE TANK IS H"

THIS IS WITHN THE MLOWABLE TOLERANCE. CAUSE: BOTTOM KNUCKLE IS SLIGATLY TIPPED IN \& FIRST PING HAD
TO BE TRIMMEO $3+$ INCHES.

PART B:

CORRECTIVE ACTION:

1. LEAVE SECONOARY CIRCUMFERENCE $15 / 5$ FOR ALL SHELA PINGS.

2. CUSTOMER TO EVALUATE THE CONSEQUENCES OE (1) AZOUE BASEO
ON THEIR REQUIPEMENTS.

3. CUSTOMEA TO ALLOW OA REJECT THE"

ON (2) ABOVE.

LEAvE AS IS "RESOALTION BASEO

Deficiency has been resolved:

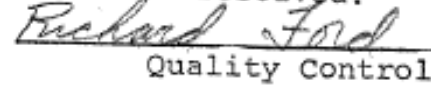

Quality Control

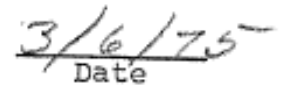

REFER TO V.T. FTM 
RPP-RPT-54819, Rev. 0

App Figure C-22. NCR B-101-31-2307-16, 241-SY Tank Farm Salt Cake Storage Facilities

\begin{tabular}{|c|c|c|}
\hline \multicolumn{3}{|c|}{ NONCONFORMANCE REPORT } \\
\hline $\begin{array}{l}\text { (1) PROJ/WO NO. } \\
\text { B-10I }\end{array}$ & \begin{tabular}{|l|} 
(2) TITLE \\
24l-SY TANK FARM SALT CAKE STORAGE FACILITIES
\end{tabular} & $\begin{array}{l}\text { (3) NCR NO. } \\
\text { B-101-31-2307-16 }\end{array}$ \\
\hline \multicolumn{3}{|c|}{ (4) DESCRIPTION OF NONCONFORMANCE - REFERENCE - SUGGESTED DISPOSITION AND JUSTIFICATION } \\
\hline Reference: & $\begin{array}{l}\text { Construction Specification B-10l-Cl, Rev. 0, } 13 \\
\text { Attachment }\end{array}$ & \\
\hline Discrepancy: & $\begin{array}{l}\text { On the Tank } 102 \text { Secondary shell, areas exist wh } \\
\text { of the line of intersection from a true straigh } \\
5 \text { feet length. (Actual measurements in areas } \\
\text { imum in } 5 \text { vertical feet.) These deviations ( } \\
\text { sult of distortions in the shell plate, were fe } \\
\text { plate-to-skirt fit-up. This condition primari? } \\
\text { smaller circumference of the first shell course }\end{array}$ & $\begin{array}{l}\text { where the maximum deviation } \\
\text { ght line exceed } 1 / 2 \text { inch in } \\
\text { shown are } 1-1 / 16 \text { inch max- } \\
\text { see attachment), a re- } \\
\text { fabricated to achieve a } \\
\text { ily contributed to the } \\
\text { se (see NCR B-101-29-2307-14). }\end{array}$ \\
\hline $\begin{array}{r}\text { Suggested } \\
\text { Disposition } \\
\text { and } \\
\text { Justification: }\end{array}$ & 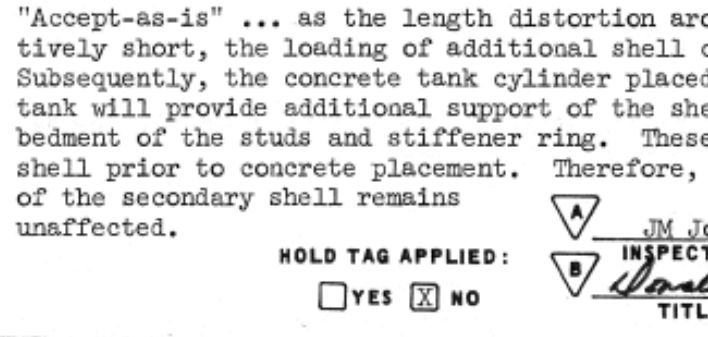 & 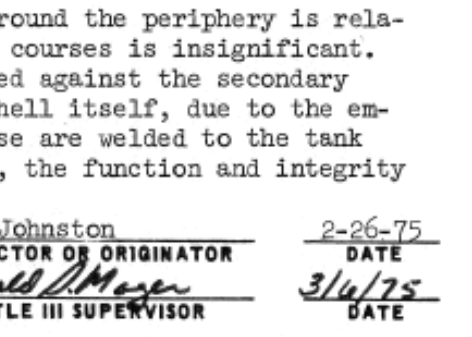 \\
\hline \multicolumn{3}{|c|}{ 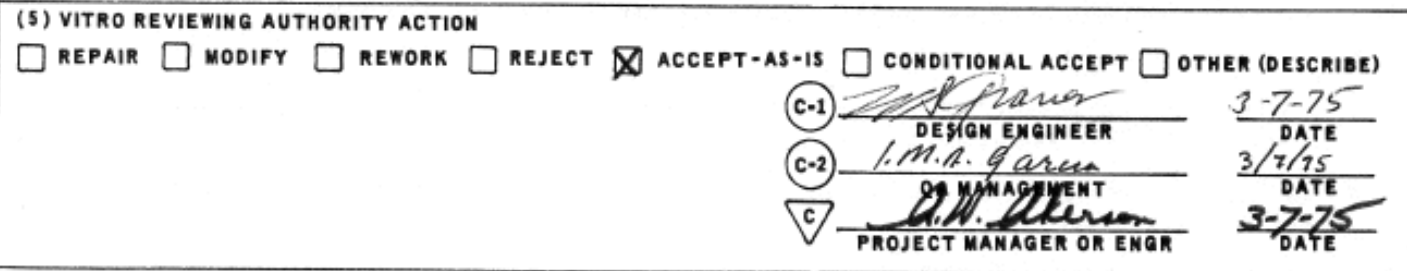 } \\
\hline $\begin{array}{l}\text { (6) CLIENT APPROVA } \\
\text { A APPROVED } \\
\text { DISAPPROVED }\end{array}$ & 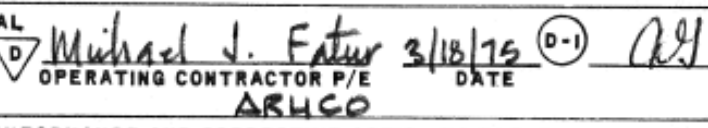 & $\frac{L_{\text {AEC }}}{\text { AEC }} \frac{3-20-75}{\text { DATE }}$ \\
\hline $\begin{array}{l}\text { (7) CAUSE of NONCo } \\
\text { Cause - The to } \\
\text { a } 90 \text { bend. Th } \\
\text { over the knuck } \\
\text { secondary tank } \\
\text { rings were ins } \\
\text { problem. }\end{array}$ & $\begin{array}{l}\text { WFORMANCE AND CORRECTIVE ACTION TO PREVEMT RECURREM } \\
\text { lerance discrepancy was caused by the shop fabr } \\
\text { is was due to the shop not being able to hold t } \\
\text { le arc length. Corrective action - This } \\
\text { knuckles. On primary tank the first } \\
\text { talled in the field correcting the }\end{array}$ & $\begin{array}{l}\text { ricated knuckle having more than } \\
\text { the } 1 \text { foot ring section vertical } \\
\text { Qon existed to some degree on } 3 \\
\text { ATURE AND TITLE }\end{array}$ \\
\hline $\begin{array}{l}\text { (8) VERIFICATION OF } \\
\square \text { OTHER (DESCRIBE }\end{array}$ & $\begin{array}{l}\text { ACTION TAKEN: ХDISPOSITION EFFECTED AS DIRECTED } \\
\text { E) }\end{array}$ & $\begin{array}{l}\text { RECORD OF FIELD CHANGE } \\
\text { MO. IMITIATED } \\
\text { MSPECTOR }\end{array}$ \\
\hline $\begin{array}{l}\text { (9) DISTRIBUTION : } \\
\text { DSM TITLE III SUPRV } \\
\text { AWA PROJ MGR/ENGR } \\
\text { CNZ QA MGR } \\
\text { WSG DESIGN ENGR } \\
\text { "TRO CENTRAL FILE }\end{array}$ & $\begin{array}{l}6 \text { NCR CONTROL DESK } \\
\text { MJF OPER CONTR.P/E } \\
\text { RAZ OPER CONTR QA } \\
\text { JEP CONST CONTR JOB SUPRT } \\
\text { WTS CONST CONTR P/E } \\
\text { CONST CONTR QA }\end{array}$ & DATE : $\frac{3-24-75}{3}$ \\
\hline
\end{tabular}


RPP-RPT-54819, Rev. 0

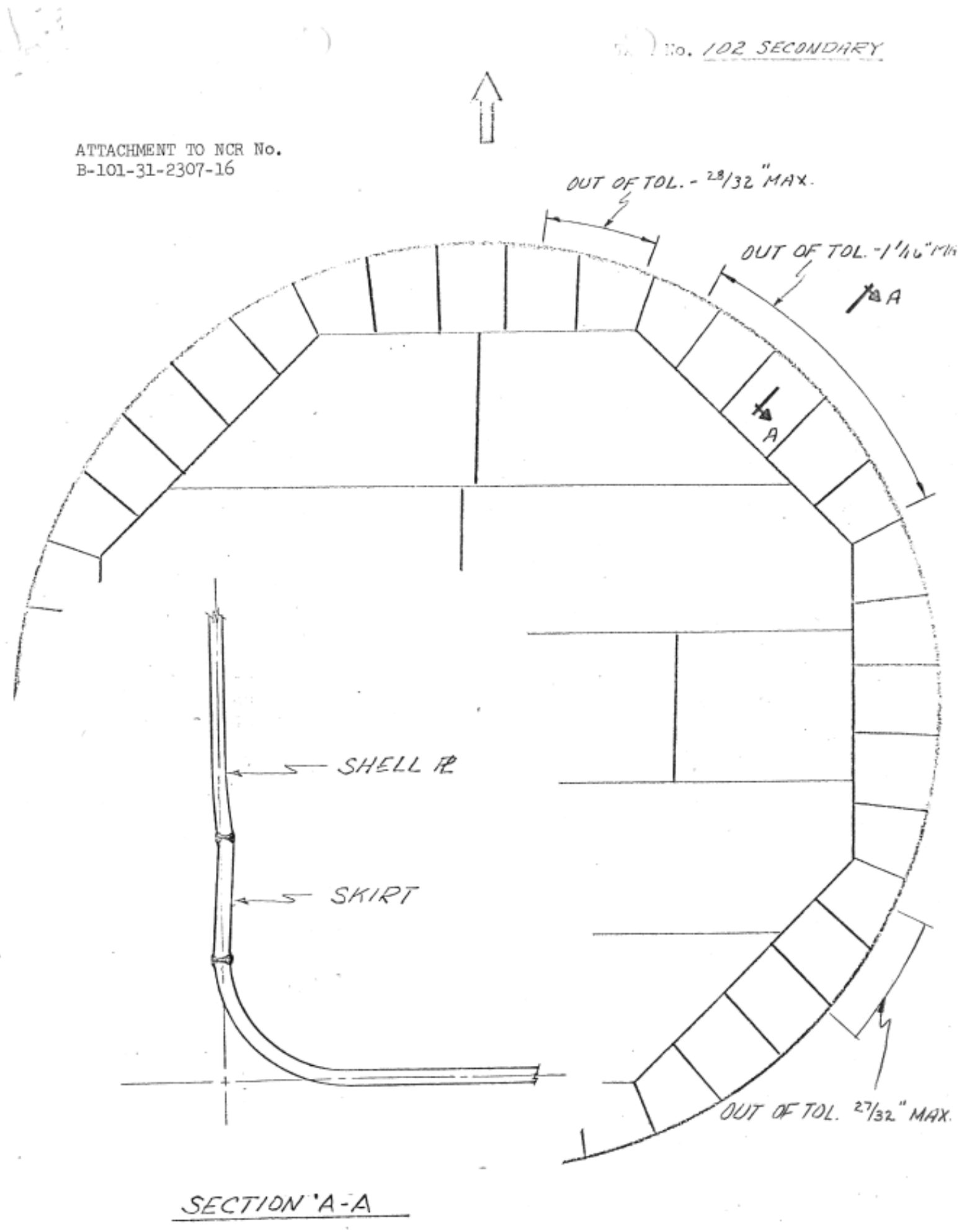


RPP-RPT-54819, Rev. 0

App Figure C-23. Tank SY-103 Primary Local Distortion Deficiency Report

DEFICIENCY REPORT

Date Initiated $6-27-75$

Initiated BY $R$ FOPD

Report No. 31

Page 1 of 2

TK 103

PART A: LOCAL AREA NOTED ON ATYACHED SKETCH EXCEEDS

DESCRIPTION: LOCAK DISTORTION TOLERANCES OFY $/ 2$ " NOTED IN

VITRO SPECIFICATIONS BHOI-CI PAR. $=14 \cdot 2-E$.

CAUSE: DUE TO THE PRESSURE CREATED WHILE FITTING + WELDING
MAKE UP ROOF PLATE.

THIS AREA WAS CHECAED FOR TOKERANCES BEFORE ROOF

PLATES WERE ERECTED \& THEY CHECAED OUT OK.

PART B: $\quad$ PLACE AREA ON HOND.

CORRECTIVE ACTION:2. CBHI RECOMENDS TO CUSTOMER TO LEAVE APEA

AS IS FOR THE FOLLOWING REASONS.

A. ASME DOES NOT ADORESS TSELFTO LOCALIZED DEFORMATIONS.

B. ASME, SECTION VIII, DIUSIONI, SECTION UG-8O DOES ADDIFSS ITSELFTO PTESSUPE

OF PIAMETER WHICH IS MET. ALLOWABLE FOR THIS TAWT WRANCES GMEN ARE IOO

C. SPECIFICATION DIAMETEP TOLERANCES ARE MET.

D. SHEL SWEEP BOARD TOLERANCES ARE MET.

E. WITH THE EXISTING LOCALI IEP DEFOAMATION TD

AND WIML NOT HAVE ANY DETRIMENZA EFFEOTS TANK REMAINS STRUCTURAKLY SOUND ICATION OPERATIONS (STRESS PEUEEA DOMEECTS DURING OR AFTER FURTHER FABP-

F. ANY COSMETC VALUE WIUL BE AOST AFTER TONCRETING).

6. REPAIR OF THE AREA WOOLD ENTAU CAFTER THE TANK IS ENCLOSED.

EXTPA BUILDLD OF PLATE EDGES AND REWELDING WHICAL AND HORIZONTAL SEAMS, WITH 3. CUSTOMER TO ALROW OR REEATEM DISTOPTIONS THAN EXIST. THE LEAVE AS IS RESOLUTION BASED ON 2. ABOUE.

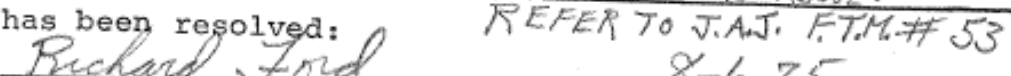
Quality control $\frac{8-6-75}{\text { Date }}$ 
RPP-RPT-54819, Rev. 0

\section{Chicago Bridge \& Iron Company}

\section{PAGE2}

TK.103

HTH RING

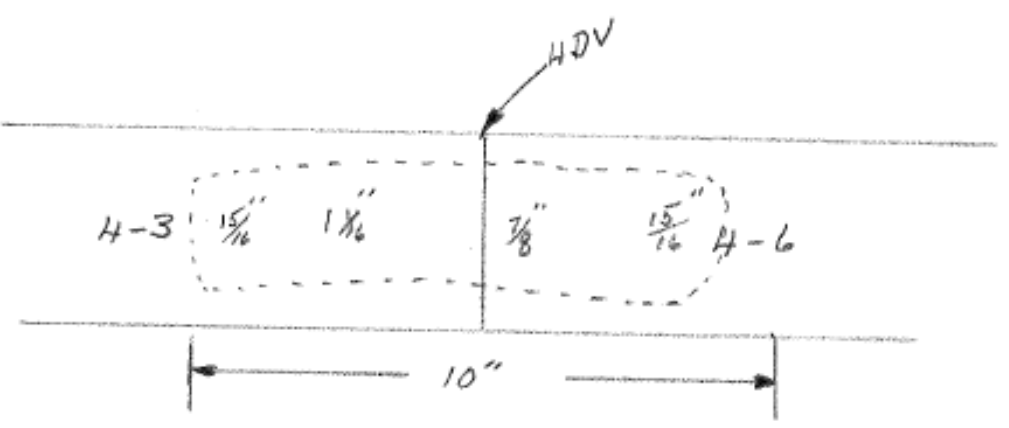


App Figure C-24. NCR B-101-38-2307-22, 241-SY Tank Farm Salt Cake Storage Facilities

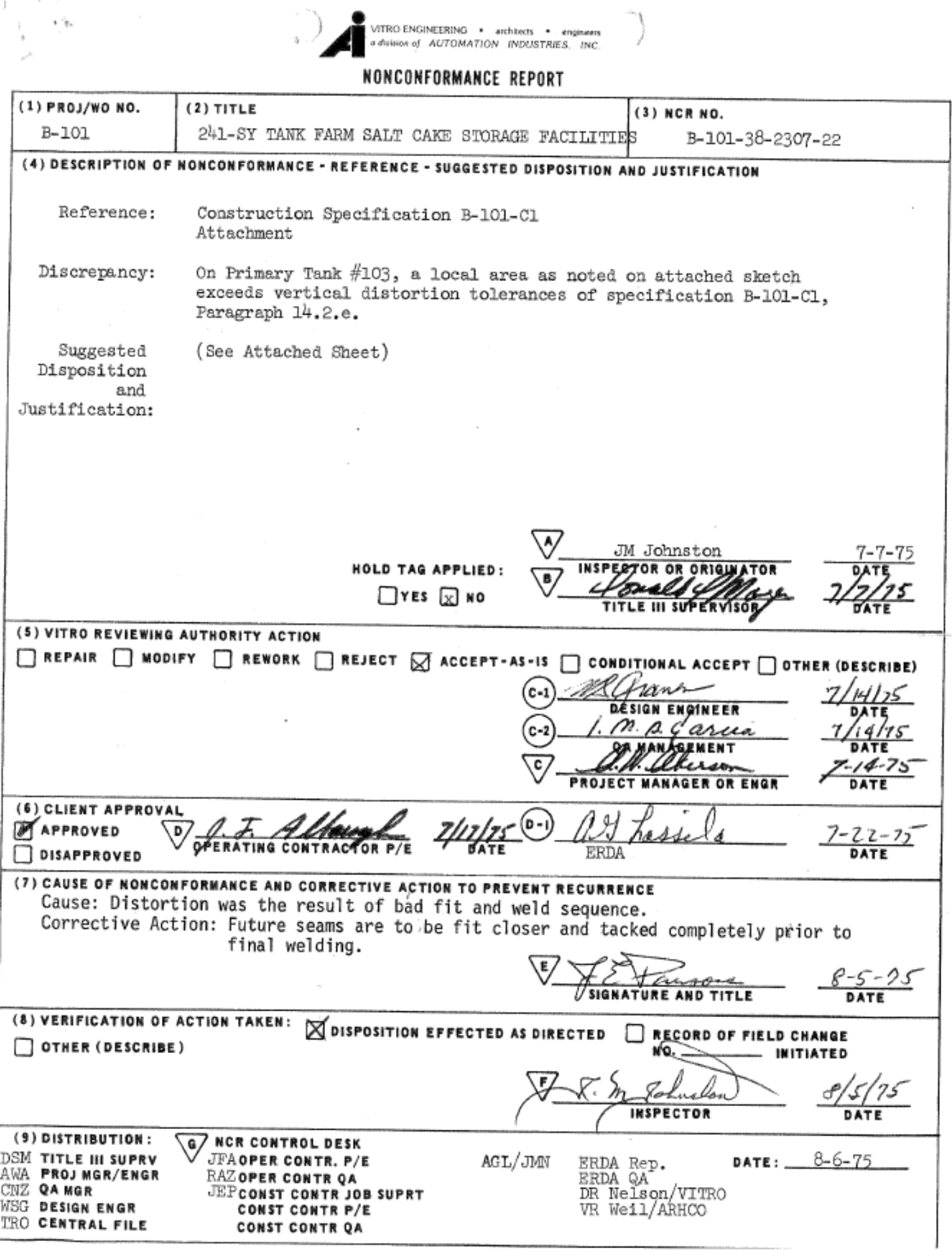




\section{RPP-RPT-54819, Rev. 0}

ATTACHMENT TO NCR No. B-101-38-2307-22

Suggested
Disposition
and
Justification:

"Accept-as-is" for the following reasons:

1. ASME Codes do not address themselves to localized deformations.

2. ASME, Section VIII, Division I, Section UG-80 does address itself to pressure vessel out of roundness of cylindrical shells. Tolerance given is $1 \%$ of diameter, which has been met. Allowable for this tank would be 8 ".

3. Specification diameter tolerances have been met.

4. With the existing localized deformation, the tank remains structurally sound, and should suffer no detrimental effects during or after further fabrication operations. (Stress relief and dome concreting.)

5. Any cosmetic value will be lost when tank is enclosed.

6. Repair would entail cutting vertical and horizontal seams, with extra build-up of plate edges and rewelding, which based on similar repair attempts would create greater distortions than presently exist. 
RPP-RPT-54819, Rev. 0

ATJACHMBNT TO NCR B-101-38-2307-22

\section{Chicago Bridge \& Iron Company}

PAGE2

TK.108

HTH RING

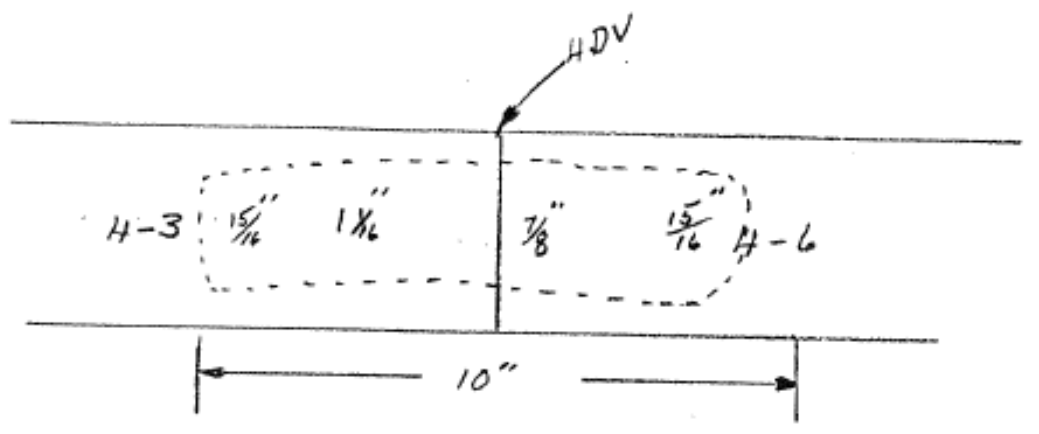


RPP-RPT-54819, Rev. 0

App Figure C-25. NCR B-101-37-2307-21, 241-SY Tank Farm Salt Cake Storage Facilities

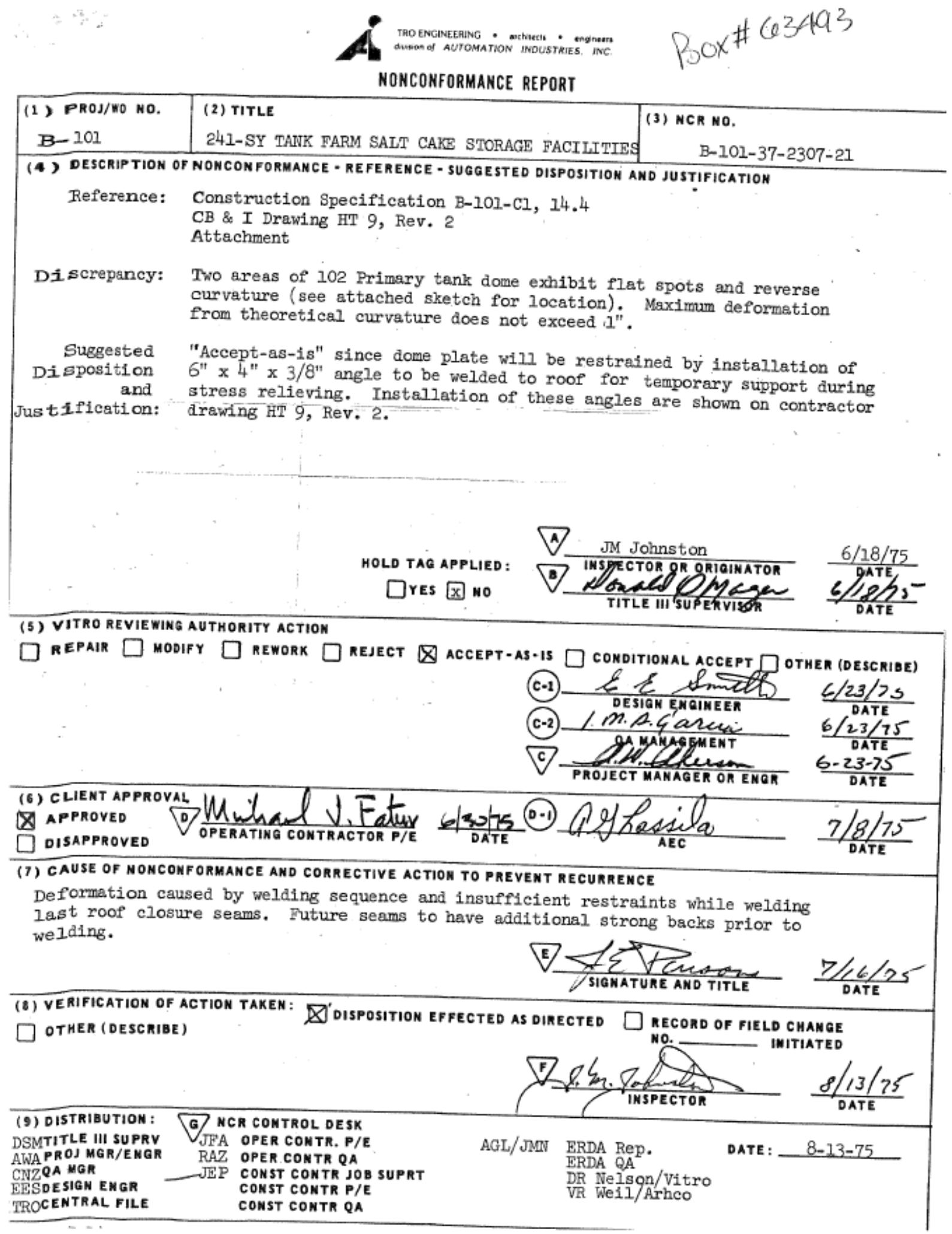


RPP-RPT-54819, Rev. 0

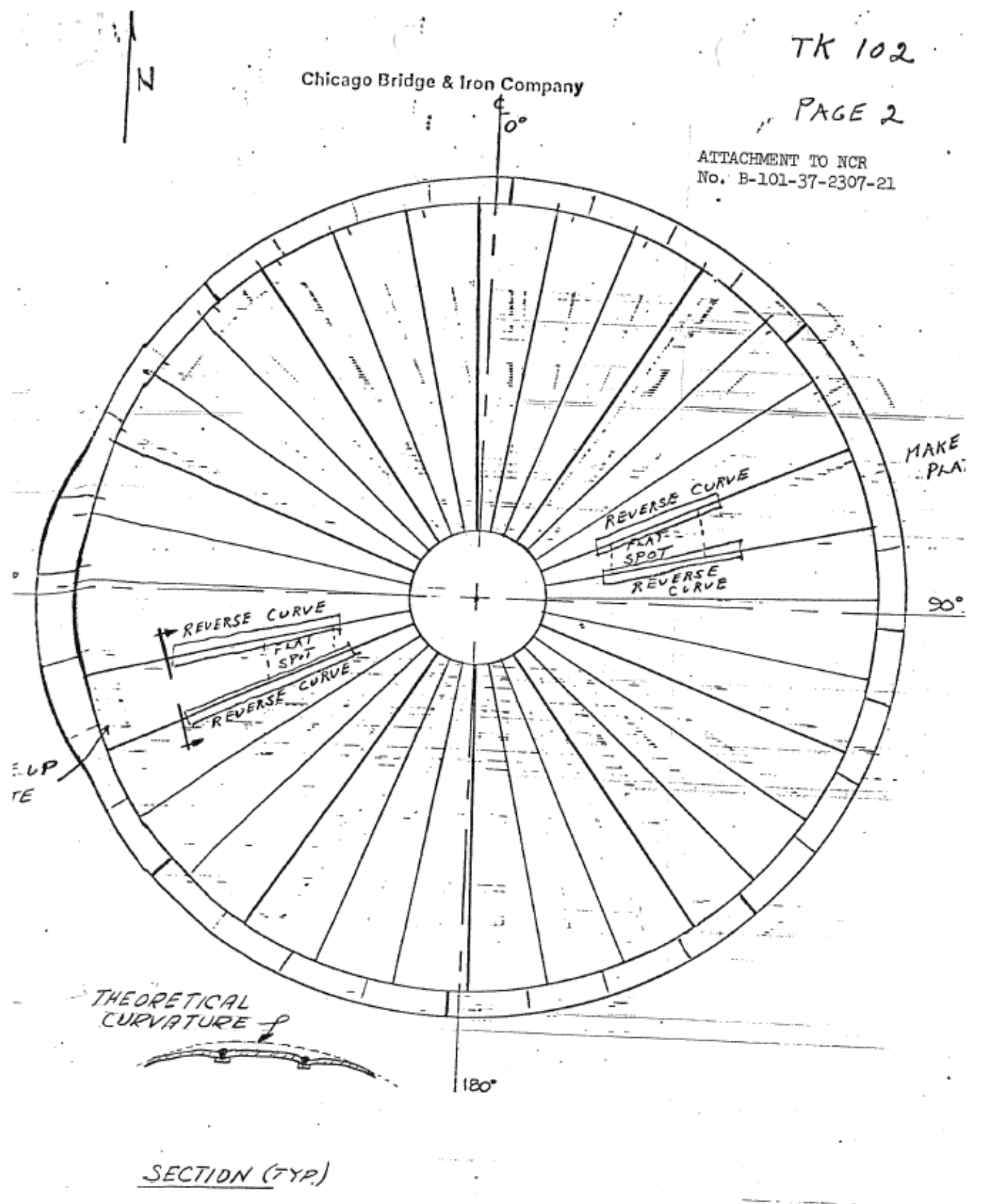


RPP-RPT-54819, Rev. 0

\section{App Figure C-26. NCR B-101-39-2307-23241-SY Tank Farm Salt Cake Storage Facilities}

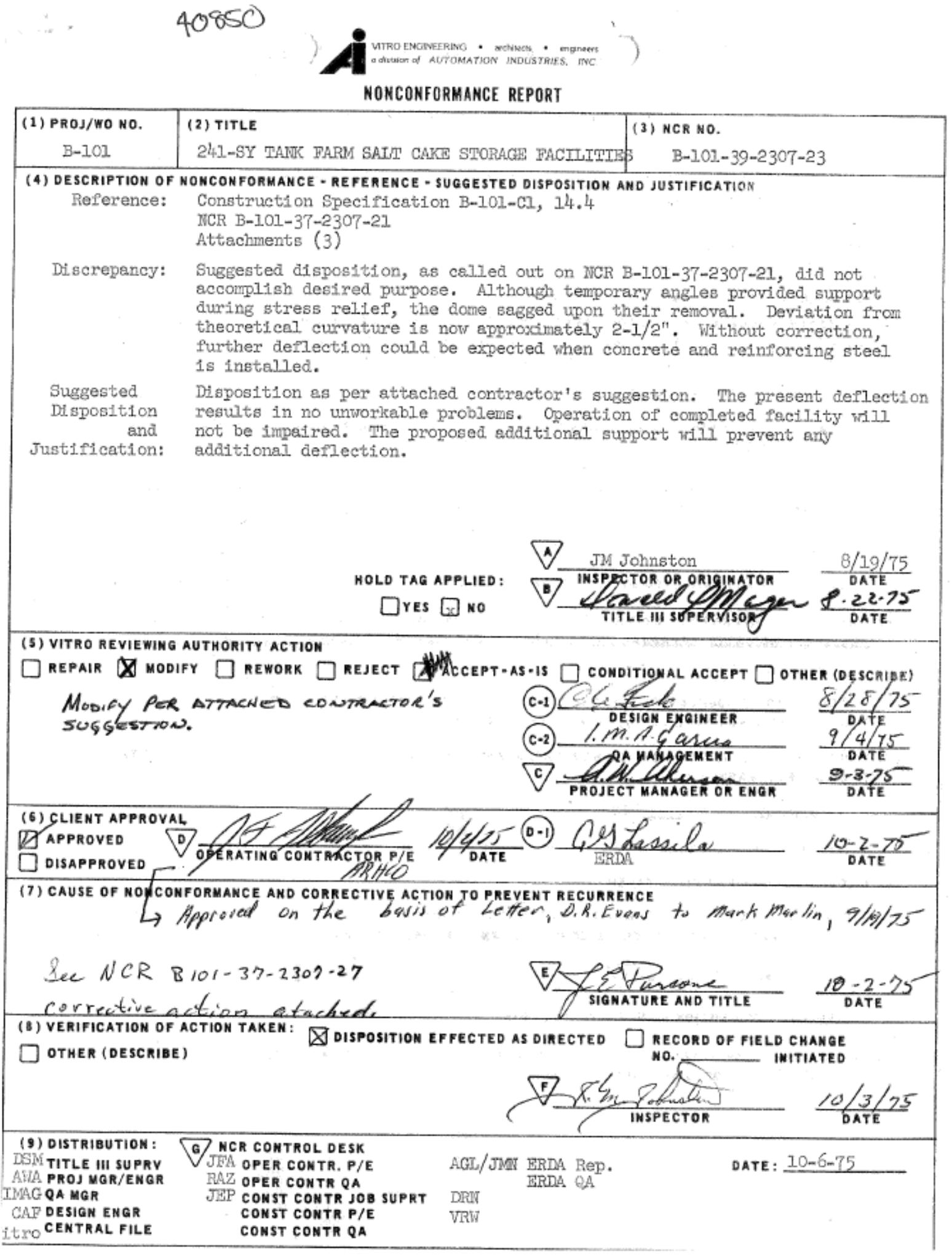

39-2307-23 
RPP-RPT-54819, Rev. 0

cc: N. Johnson - Houston Construction Services

R.J. Browning - New Castle Engineering

C.R. Patterson/T. Fraser - OB Operations

RWM/BER/OSE 74-24090

SCL

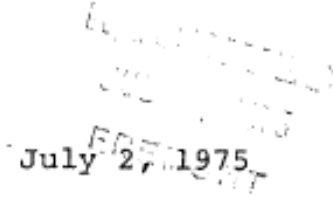

Bob Evans

Fremont construction

RE: Contract 74-2409U

Rad Waste Storage Tanks

Richland, Washington

This letter will confirm information we discussed by phone today concerning the flat spot in the roof of Tank \#1. The following is the sequence to be used for stiffening the roof adjacent to penetration $20-1$ at $270^{\circ}$ centerline:

1. Install and weld complete the dollar plate.

2. Leave all stiffening presently in place until flat spot has been pulled up and secured.

3. Refer to attached sheet \#l for stiffening details. Install circumferential stiffeners and weld complete. If depressed area extends inside $17^{\prime}-6^{\prime}$ radius or outside 22'6". radius, additional circumferential stiffeners will be required.

4. Install all radial stiffeners required and weld them to circumferential angles.

5. Pull roof plate up to radial stiffeners and weld. If additional circumferential angles are required, span between them with additional radial stiffeners.

6. If above system stabilizes the roof in this area, remove all other stiffening from roof.

7. Stiffening at depressed spot must remain in place through concreting. If customer will not accept this, then we will have to stiffen the underside of the roof and remove this stiffening after concrete is set up.

Since the other 20-1 penetration at $90^{\circ}$ centerline is not having similar problems, we assume that the cause of the settlement 
RPP-RPT-54819, Rev. 0

ATTACPMEITT TO NCR B-101-39-2307-23

Page 2

July 2, 1975

Bob Evans

at $270^{\circ}$ is due to the initial flat spot in the roof. Therefore, we do not anticipate similar problems with Tanks $\# 2$ and \#3 unless they have similar flat spots before PWHT. If there are problem. areas on these tanks, we advise stiffening these areas locally before PWHT and leave stiffening on through concreting. Also, we emphasize the requirement for installing the dollar plate before removing any roof stiffeners.

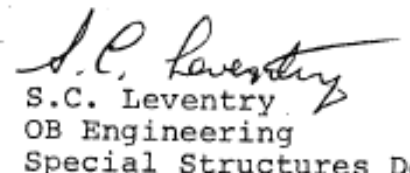

Special Structures Design 


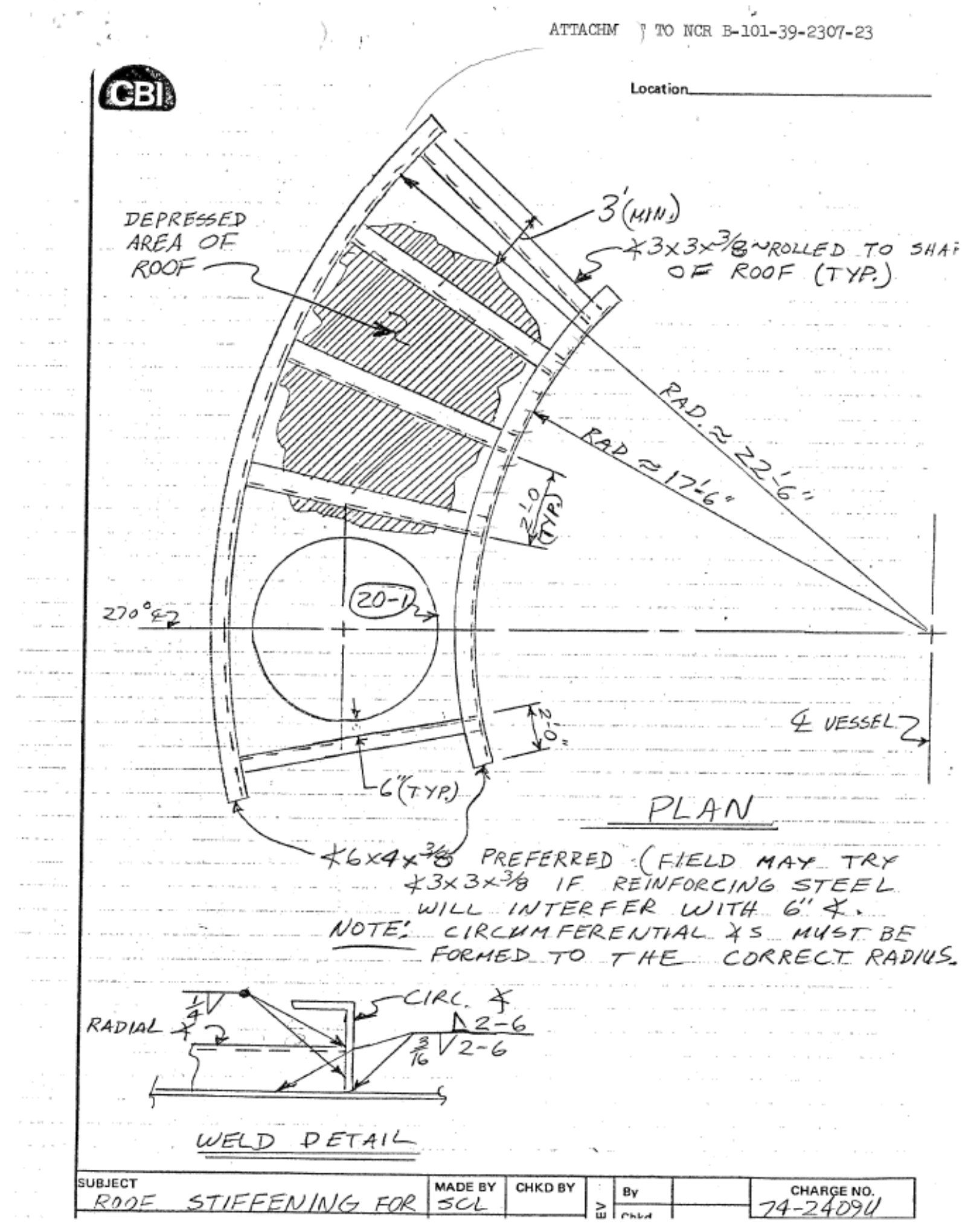

